\title{
THROUGH \\ UGANDA TO MOUNT ELGON
}

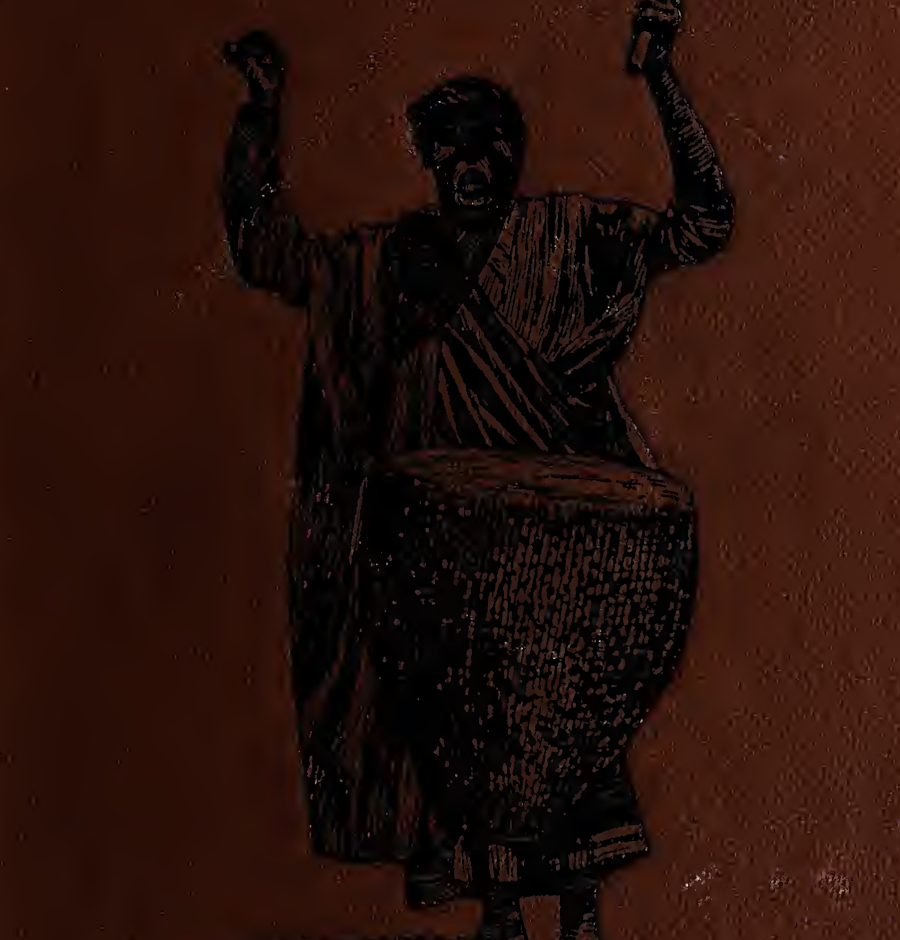

4. ith

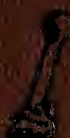



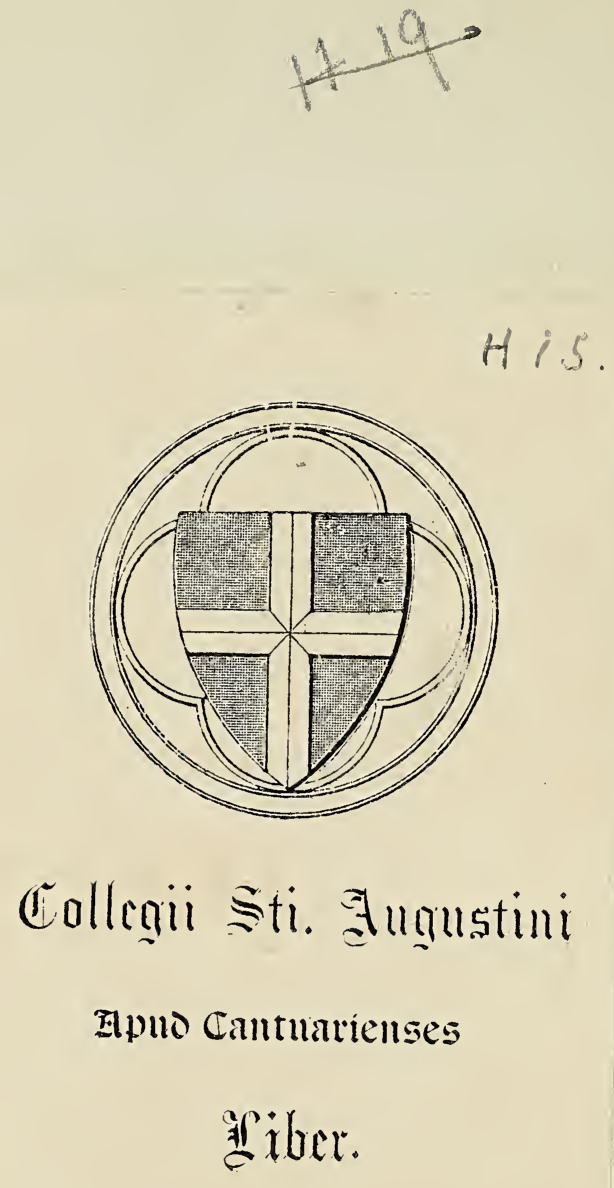


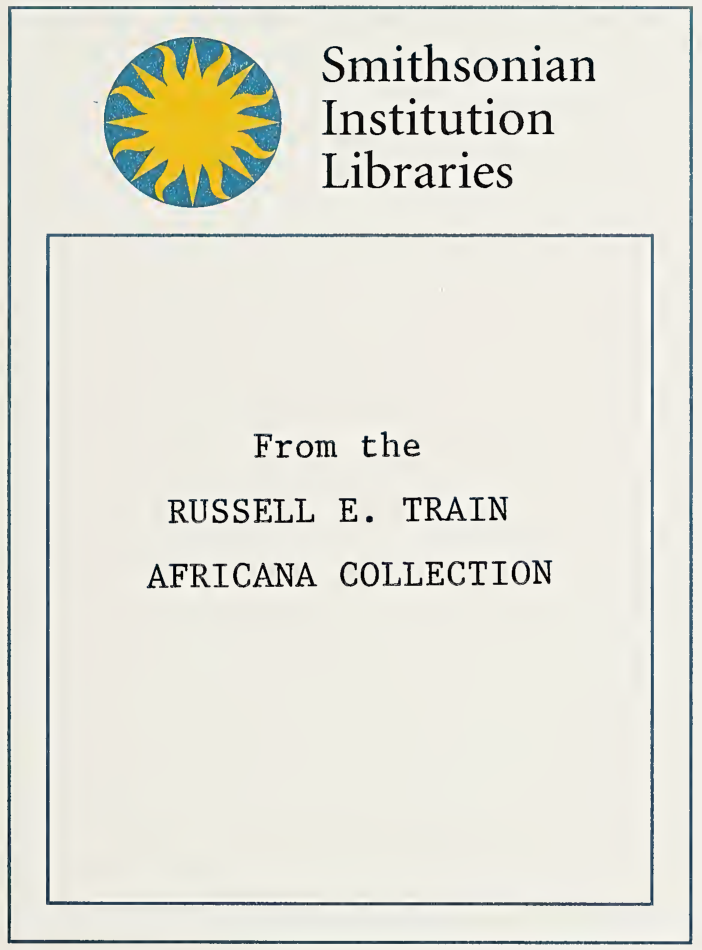



THROUGH UGANDA TO MOUNT ELGON 


\section{TWO BOOKS ON CENTRAL AFRICA}

\section{UGANDA TO KHARTOUM.}

By AlberT B. Lloyd, Author of "In Dwarfland and Cannibal Country." Fully Illustrated. Cheap

Edition. Large crown 8 vo, cloth, 5s.

"In Mr. Lloyd we have a noteworthy example of the sporting missionary. His stories of big game shooting are by no means the least interesting portions of a book which is full of strange incidents and thrilling adventures in a remote and little-known corner of the British Empire."-Standard.

\section{TRAMPS ROUND THE MOUNTAINS OF THE MOON AND THROUGH THE BACK GATE OF THE CONGO STATE.}

By T. BRoAdWOod Johnson, M.A. With 30 Illustrations from Photographs. Large crown 8vo, cloth, 6s.

"Mr. Johnson has had many strange and interesting experiences, and he knows how to describe them in plain, vigorous English. At the same time he throws a flood of light on the nature of British rule and the progress of the mission work now firmly established. The book is a valuable addition to our knowledge of Equatorial Africa."-The Daily News.

LONDON : T. FISHER UNWIN 



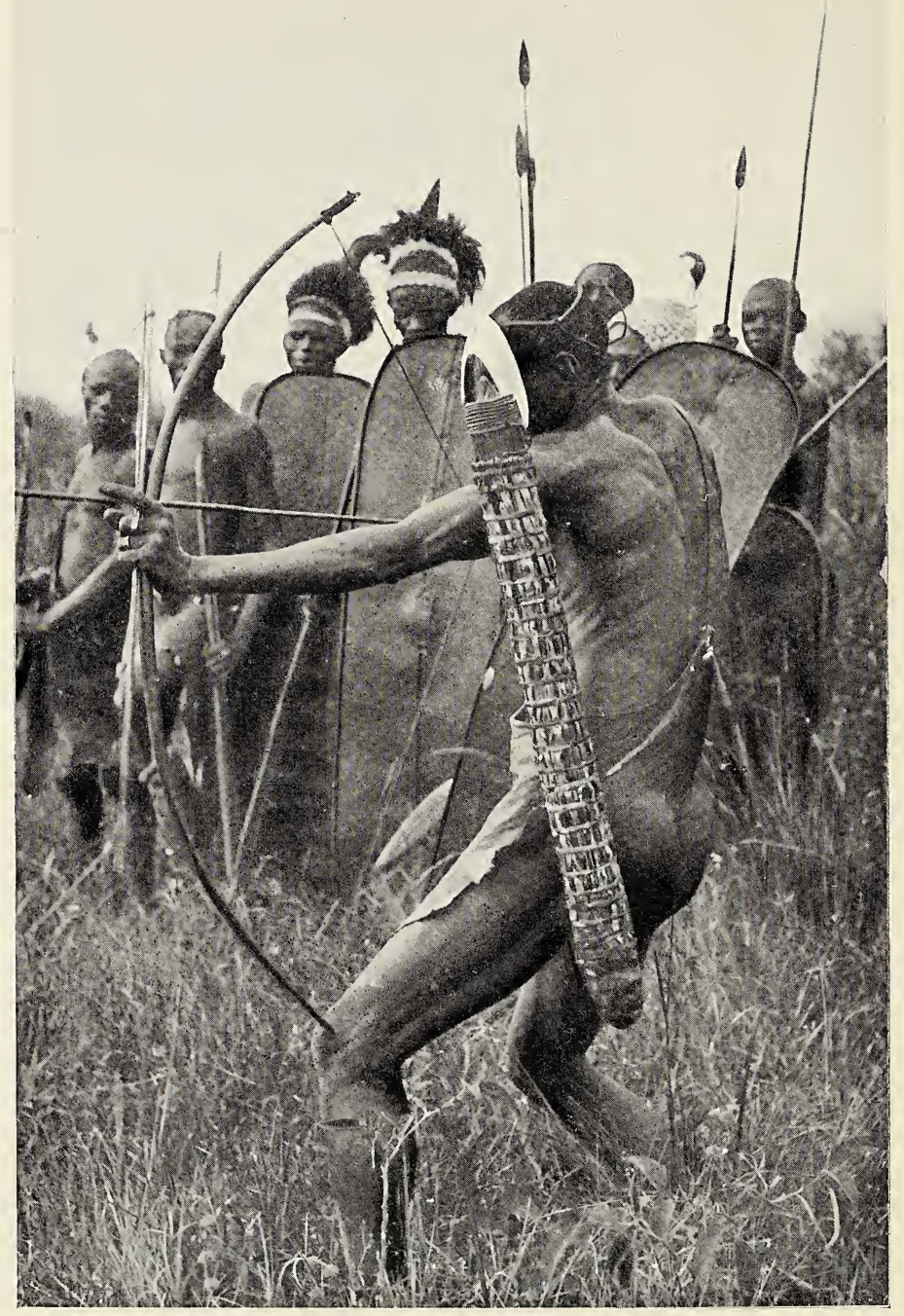

BAGISHU WARRIORS OF MOUNT ELGON,

Frontispiece.] 


\section{THROUGH UGANDA \\ TO MOUNT ELGON}

By J. B. P UR V IS AUTHOR OF "BRITISH EAST AFRICA AND UGANDA," “THE LUMASABA GRAMMAR," ETC.

WITH A MAP AND 42 ILLUSTRATIONS

T. F I S H E R U N W I N LONDON: ADELPHI TERRACE LEIPSIC : INSELSTRASSE 20 1909 


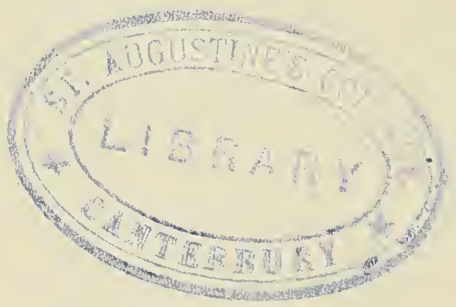

(All rights reserved) 


$$
\begin{aligned}
& \text { DT } \\
& 434 \\
& 32 \\
& P 98 \\
& 19096 \\
& \text { SENHNON }
\end{aligned}
$$

TO

MY WIFE 



\section{CON'IEN'IS}

\section{CHAPTER I}

A land worth seeing-How to get there-German versus English enterprise-The journey-Mombasa - Kilindini harbour-The native town-Slavery-The enterprise and influence of Missions-Transition-Value of coast-lands -The Uganda Railway-The journey to the capital.

\section{CHAPTER II}

\section{THE CAPITAL OF BRITISH EAST AFRICA}

Nairobi-A bad start-Progress - Strong opinionsKnotty problems-Forcing the hand of the Administration-"Put the native in his proper place"-The destiny of the African-Is he capable of mental and moral development?-The Governor of British East Africa-The settler-Will he ever be able to make a permanent home in the Highlands of Africa? - The evils of competition-The problems of race and colour very pressing-Locate the white man as well as the black-Is the Asiatic a "settler"? -The intermingling of the Aryan and Negro-Develop the country through the native-Organise and educate the negro-Disintegration of native customs - Taxation-Rearrange old tribal systems. 


\title{
Contents
}

\author{
CHAPTER III
}

THE NATIVE • • • • • •

Four millions of natives - The Swahili-Arab and African - Arab influence - Swahili nature - "Black ivory"-Mohammedan missionaries-Primitive tribesThe Wakamba-Ideas of beauty-Religion-The Wakikuyu - Their industry - Ornaments - Polygamy Unrest-The Masai - "Fierce, nomadic warriors"Nilotic negroes-Pastoral people-Dress-WarriorsHouses-Women's work-Engaged-Ear-rings - Sacred objects-The Great Spirit-A problem.

\section{CHAPTER IV}

FROM NAIROBI TO LAKE VICTORIA

The most beautiful country-The great "fault"-The Mau Escarpment-Giant timber-A serious rainstormPoisoned arrows-Nandi troubles-A caravan cut upPort Florence-Kavirondo peoples - A surprise - The tropics indeed-The C.M.S. - The power of exampleThe sight of a lifetime-The day of opportunity for the Christian Charch-Education or Evangelisation?

\section{CHAPTER V}

THE LAKE VICTORIA : ITS SURROUNDINGS AND SCOURGE

First view of Lake Victoria-A sight to enraptureWaiting for breakfast-A picture from fairyland-The islanders of Sese-A voyage of discovery-Life hanging by a thread-From Uganda to German territoryBaganda influence-Dangers of the sea-The BavumaSteamers-Area and variety of Lake-A round tripSleeping sickness-Death and desolation-Doctors A. R. and J. H. Cook-Sleeping sickness means great suffering 


\section{Contents}

-Dangerous patients-Spread of the disease-Cause of the tragedy-The tsetse fly-The crocodile theory-Is there a cure? -Experiments-A barrage over the Ripon Falls-Nearing Uganda.

\section{CHAPTER VI}

UGANDA : FLORA, FAUNA, AND OTHER THINGS

Beautiful Entebbe-Capital of civil administration-The native opinion-A mistake-The road to Mengo-No advance - Appearance of country - A large gardenCotton cultivation-Value of cotton export-Climatic conditions-Extent of Uganda Protectorate-Agricultural possibilities-Rubber, cultivated and indigenous-A cheap concession-Timber-Wild animals - A bull buffaloDeath of Dr. Densham-A native report of a lion huntInsect pests-Mosquitoes and malaria-Value and use of mosquito nets - Danger of rest-houses - Necessity of change-Protection against sun-Blackwater fever.

\section{CHAPTER VII}

The amazement of travellers-Stanley's expectationsConcentrated cruelty-Mtesa's smiling welcome-The people of Uganda-System of government-Social lifeThe Bahuma-Native wine-The other side of the picture -Mtesa, the causer of tears-Mwanga, a cruel son of an evil father-Alexander Mackay-"The dark places of the earth "-Effect of missionary effort-Expulsion of missionaries-Murder of Bishop Hannington-Growth of Mohammedanism - Influence of native Christians Rebellion, capture and death of King Mwanga-King David-Light and liberty. 


\section{CHAPTER VIII}

UGANDA : ITS PRESENT ADMINISTRATION

No Uganda Railway-Porterage system-No relief for British taxpayer-Sir H. H. Johnston-Provincial chiefs -Pax Britannica-One Governor suggested for East Africa and Uganda-Tropical diseases-Native development or revenue--King David at home-Native parliament-Regents-Sir Apolo Kagwa, K.C.M.G.-Native capabilities and possibilities-Chamber of Commerce and Labour problem-Road-making-Waste of labour-Transport facilities-Need for technical education-Military service--Strategic position of Uganda-The Right Hon. Winston Churchill and the Baganda.

\section{CHAPTER IX}

\section{THE SIGHTS OF MENGO}

Kampala-Nakasero-Uganda Company, Ltd.-Philanthropy and percentage-Cotton ginning and balingStones sold at cotton price-Uganda newspapers-Roman Catholic Missions - Roman disunion - C.M.S. headquarters-The Cathedral and congregation-The Uganda drum-Missionary meetings-God's Acre-The Soudanese Rebellion-Sad days-Mengo Hospital-High SchoolThe Bishop's palace.

\section{CHAPTER X}

\section{THE WORK AND INFLUENCE OF MISSIONS}

True Socialism-The life of women-Native missionariesCondition of the Church-Appalling numbers-Numerical not necessarily moral strength-Danger of numbersDanger of civilisation-The housing problem-Superficial character-Evil living-Johnston's opinion as to Uganda's 


\section{Contents}

PAGE

need-A Puritan revival--Secular education-Desire for knowledge-Intelligent people-The education problemDuties of Church and State-Church government-White missionary not permanent-A constitution-Self-support and self-extension-Lack of funds and permanent buildings-The crisis of the nation and the Church-HopeQuestions of Church practice and discipline-Organisation -A division of the diocese.

\section{CHAPTER XI}

\section{THROUGH USOGA}

A journey eastward-Kyagwe-Ham Mukasa-A visit to England-Samwili Kangawo-Perfect gentlemanWayside camps-A view of Lake Victoria and UsogaRipon Falls-Whence the Nile springs-A dangerous ferry-A unique welcome-Jinja and its possibilitiesFrom Lake Victoria to Egypt-Agriculture-Road-making -A good centre-Clever thieves-Slow work-Christian revenge-Famine-Hut-tax returns-Value of a paramount chief.

\section{CHAPTER XII}

ON THE MARCH IN UNKNOWN LANDS .

Bukedi-River Mpologoma-Dug-out canoes-PapyrusDisenchantment-Strange dwelling-places-Lake Kyoga -Floating islands-A spicy experience-Teso countryClothing despised-Remarkable village fences-Curious ornaments-The care of children-Precautions for benefit of girls-Fear of a mother-in-law-Mission work-Lake Salisbury-A primitive race-Turkana people-Hairdressing and use of pillows. 


\section{Contents}

\section{CHAPTER XIII}

MASABA : COUNTRY, PEOPLE, AND CUSTOMS .

A cool camp-The largest extinct volcano in the worldMount Elgon and its foothills - Masaba-Primitive customs-Caves and cave-dwellers-The wildest people in Uganda Protectorate-Native customs-CircumcisionPatriarchal government-Clan system-Land laws Heirship-Marriage laws and customs-Dress of married woman-Clan marks-Ornaments-Protection of girlsPunishment of wrong-doers-Clan fights-Native courtesy - Spirit of independence-Jealousy-A father's curseCurious customs.

\section{CHAPTER XIV}

\section{LIFE AND WORK AMONGST CANNIBALS}

Lost near Mount Elgon-Quaint figures - Clothing despised-Invalid missionaries-A cheap house--Human hyænas-The place of departed spirits-Burial customsThe gathering of the clans-The coming of Roman Catholics - Laying out a station-Native kindnessProgress-A unique church dedication-Variety of work -Healing powers of nature-First baptisms.

\section{CHAPTER XV}

\section{LANGUAGE DIFFICULTIES}

Preliminary difficulties-Publication of the Lumasaba Grammar-A primitive language-Legend about Victoria Nyanza Bantu group-Comparative study advisedBantu language characteristics - Confusing similarity in Luganda-Perfect grammatical construction-Rich vocabulary-How to express abstract ideas-A faithful lad-A prayer- and hymn-book-Idiomatic phrasesPoliteness. 


\section{Contents}

\section{CHAPTER XVI}

\section{LIGHT AND SHADE}

Slow progress-Friendly and trustful natives-Spirit of independence-Indian hemp-smoking-Effect of evil practices-Native dances-Drink and fighting-WailingNative industry-Lighthearted geniality-WitchcraftThe power of suggestion-Protection against witchcraft -No God of love in Masaba-Evil spirits-Altars and offerings-Sacrifices-Sacred groves-A liking for football -Ghoulish practices-A low standard of civilisationCompensations - Native ability-Open doors.

\section{CHAPTER XVII}

NATIONALISING AND DENATIONALISING THE NATIVE .

The unsettling of the native mind-Bringing them into line-A bad inheritance-Painful memories-The evils of armed agents and punitive expeditions-ImprovementsPossibilities. 



\section{LIST OF ILLUSTRATIONS}

PAGE

BAGISHU WARRTORS OF MOUNT ELGON . . Frontispiece

CROSSING THE RIVER MPOLOGOMA IN A DUG-OUT CANOE . 20

MASABA CHIEFS ON A VISIT TO THE EUROPEANS . • 25

TESO HUNTERS FROM THE HINTERLAND • . • . 29

NATIVE-MADE BRIDGE OVER A DANGEROUS RIVER • . 35

THE NATIVE AT PLAY $\quad$. $\quad$. $\quad$. $\quad$. $\quad$. 41

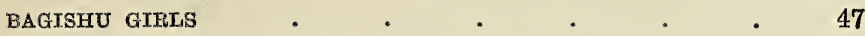

TXPES OF WOMEN AND GIRLS, MASABA, MOUNT ELGON • . 51

A HARD DRINKER AND MEDICINE-MAN $\quad \cdot \quad$. $\quad 61$

BAGISHU ABOUT TO OFFER SACRIFICES . . . . 65

"ENGAGED" GIRLS . . . . . . . . 76

MASAI WARRIORS GUARDING A TRAIN ON THE UGANDA RAILWAY 81

THE HOME OF THE TSETSE FLY . $\quad . \quad$. $\quad . \quad .99$

A GOLDEN-CRESTED CRANE $\quad$. $\quad$. $\quad$. $\quad$. $\quad$. 112

THE KING OF UGANDA'S OFFICIAL DRUMMER . . . 134

H.H. KING DAUDI (DAVID) CHWA $\quad . \quad$. $\quad . \quad 147$

KING DAVID LEARNING THE MYSTERIES OF A KODAK • . 155

SIR APOEO KAGWA, K.C.M.G. • . . . . . 159

INTERIOR VIEW OF MENGO CATHEDRAT. . . . 174

ST. PAUL'S CATHEDRAT, MENGO, UGANDA . . . 174 


\section{8 List of Illustrations}

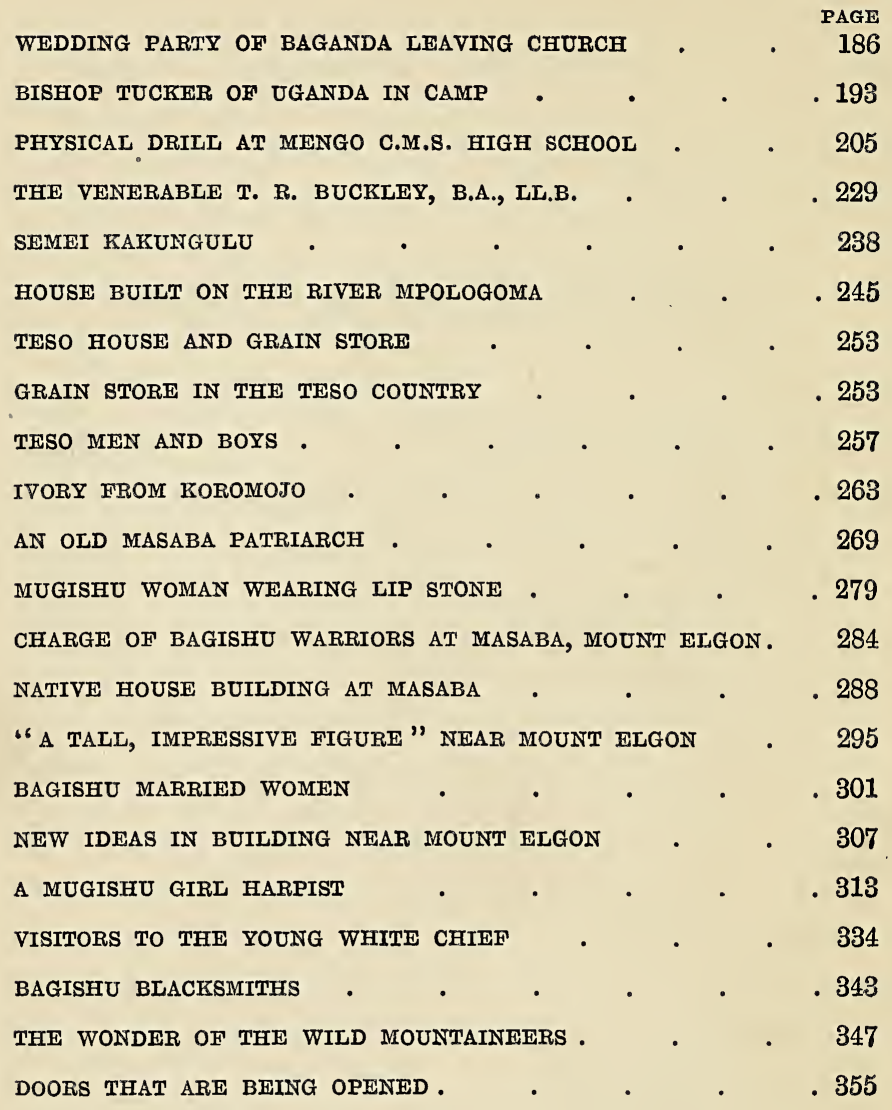

MAP

ROUGH SKETCH OF CENTRAL PROVINCE OF UGANDA PRO-

TECTORATE AS EXPLORED BY THE REV. J. B. PURVIS 220-221 



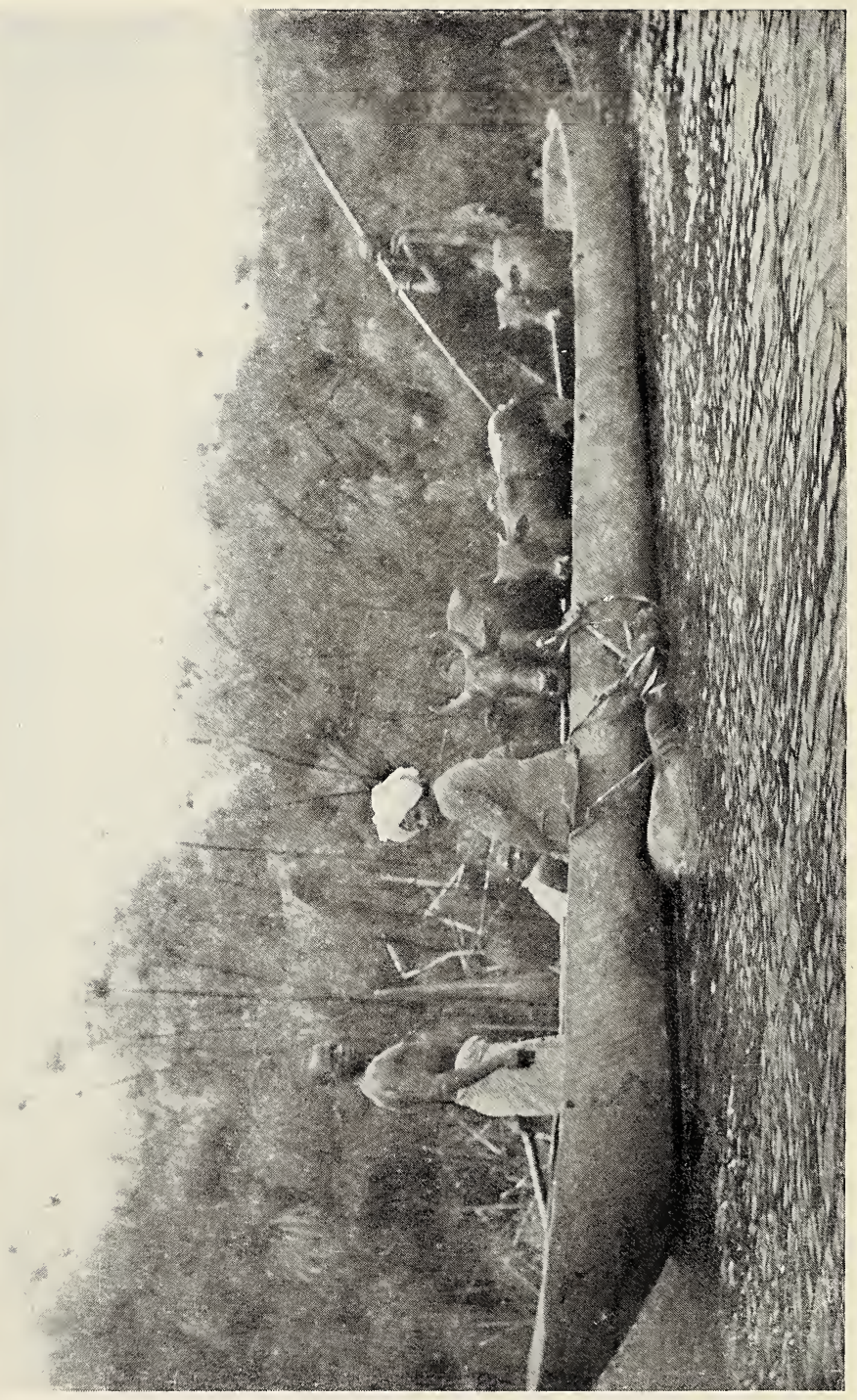




\section{THROUGH UGANDA TO MOUNT ELGON}

\section{CHAPTER I}

\section{FROM ENGLAND TO THE HIGHLANDS OF AFRICA}

A land worth seeing-How to get there-German versus English enterprise--The journey-Mombasa-Kilindini Harbour-The native town-Slavery-The enterprise and influence of Missions-Transition-Value of coast-landsThe Uganda Railway-The journey to the capital.

$\mathrm{H}^{\mathrm{OR}}$ the man who is tired of the beaten 1 track, and who wishes to "see things as they are" in a land which, up to the last few years, was "the Dark Continent"-things that are well worth seeing, since they are all that remain in the world of a primitive simplicity that cannot possibly last much longer-let me commend a visit to our East African Empire. The "How to get there?" is no longer a 


\section{Uganda to Mount Elgon}

problem, or even a trial, in spite of the fact that British enterprise played no part in the solution of the difficulty. Without so much as an effort on the part of British shipowners, the Germans have taken possession of East African trade, and are even polite enough to call at Dover for would-be visitors to East Africa and Uganda.

Those who prefer a short sea passage have only to go overland to Marseilles or Naples, from whence they may reach Mombasa in fourteen days.

I do not say that German ships are all that can be desired, more especially to the man who has not learned to eat pork chop for breakfast, when passing down the Indian Ocean in the face of a monsoon; but $I$ understand that even such food as a German liner can offer is preferable to the diet of-well, amongst other things, substantial cockroaches, which figured so prominently on some of the older boats that once plied between Aden and Mombasa.

Even in the matter of boat and diet a choice is given, though some may think the choice is between two evils, for whoever cannot travel by a German line may try the French, and perhaps prefer it. Here, almost the only difference between first and second class is the difference in the price and sleeping

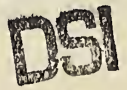




\section{A Pleasant Voyage}

accommodation. The food of first and second class is very similar, and the promenade-deck accommodation is the same.

By either line a very pleasant voyage can be made, giving glimpses of Southern France, Naples, Vesuvius, Stromboli, Messina, Etna, Port Said, the Suez Canal, and Aden-glimpses of life and colour which live in the memory for ever.

With little difficulty it is possible to break the journey at Port Said, and from thence visit the Holy Land or view the sights of Egypt.

For myself, I kept straight on, thankful for the breezes of the Indian Ocean-spicy breezes indeed, since they passed over various cattlepens placed immediately in front of my cabin window, but nevertheless acceptable after the deadly calm and prostrating heat of the Gulf of Suez.

A little speck in the far distance grows gradually into shape until it becomes to us, after naught but sea and sea and sea, the most beautiful island in the world. The ringting-ting of the engine-room telegraph, and the vessel goes slower and slower as we glide into the harbour. A sharp command, the loud rattle of the anchor chain, and we have finished the first stage of our journey to Uganda. Mombasa at last; and all the island seem to have taken a 


\section{Uganda to Mount Elgon}

day's holiday to visit the incoming steamer. A shoal of boats rush for the gangway, to be pushed off and off and off again, to sort themselves into the proper order of boarding. First comes the doctor, who, having declared a clean sheet, goes off again to shore, his departure the signal for another rush of boats of all sorts and sizes, with owners of every colour in the rainbow.

"Letters for you from up-country," says some one, and I read to find myself located to Masaba.

"Wherever in the world is Masaba?" thought I, and left a question of geography, which seemed impossible to solve at the coast, to be cleared up when I should reach Mengo, the capital of Uganda, and local headquarters of our mission; and in the interval sought a closer view of Mombasa, interesting always, but doubly so to one who saw it before the younger world had begun to cut, and mould, and shape, and build as it is doing at the present day.

Remembering my first visit in 1895 to the island, with its narrow street of Arab houses, old Portuguese fort, innumerable smells, and crowds of that happy-go-lucky, but useful, species of humanity, the Swahili porter, who, with his jolly smile, seemed to have but two 


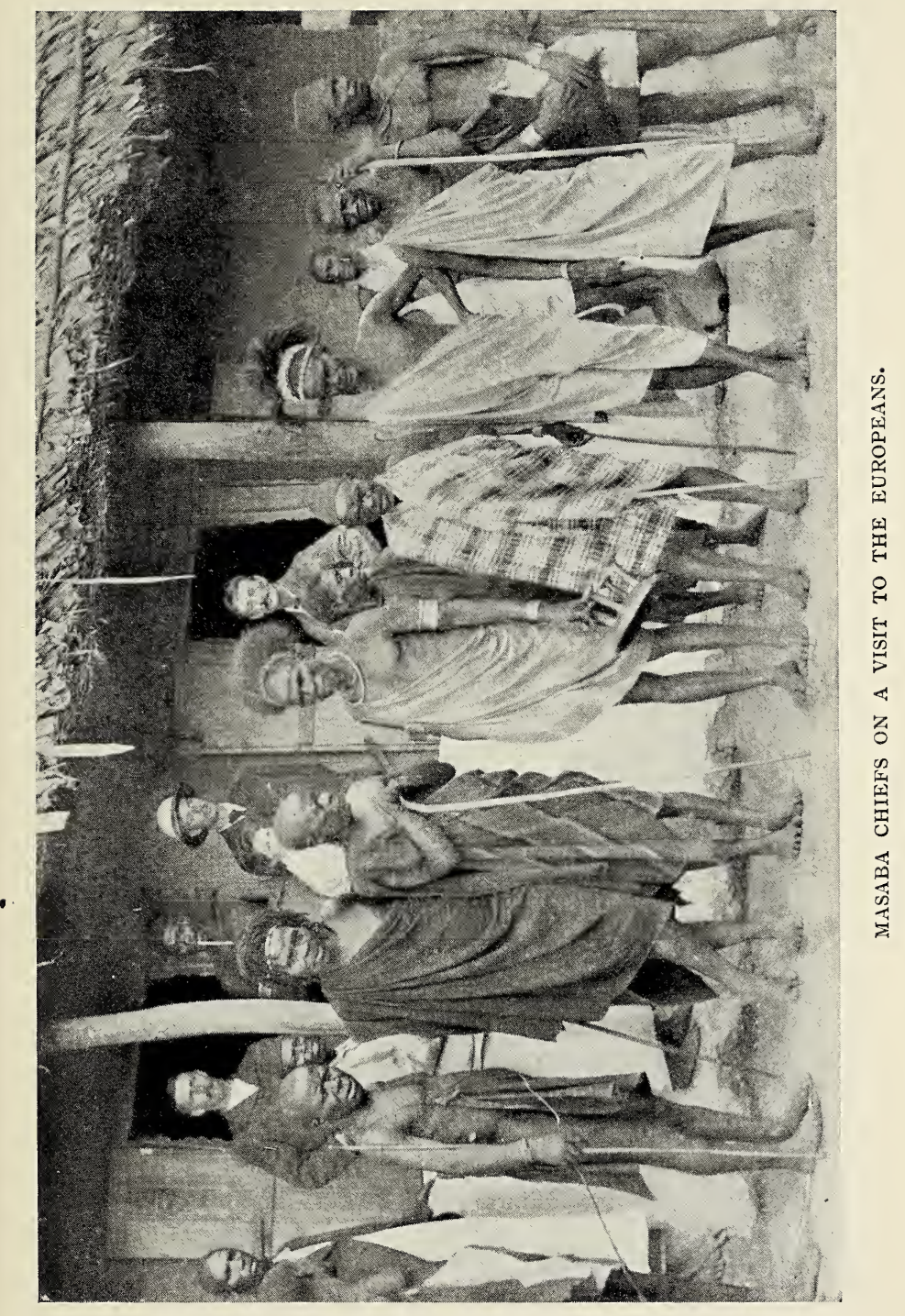





\section{Old Mombasa}

ambitions in life-the first to find out the exact state of one's health, with his continual "Jambo bwana, jambo? u hali gani?" and the second to convince the new-comer that to go off into the interior without such a paragon of usefulness and integrity as the speaker would be the height of folly; I see once more the miserable aspect of the island in those days! The one narrow, evil-smelling street above mentioned, an English hospital, and Government House standing lonely and desolate; the old native town, a mission hospital, and for all the rest--not excepting the old fort, although it was the home of criminals, of porters being kept under lock and key until the very moment of marching, and of the then Postmaster-General-long grass, trees and brushwood, the paradise of snakes, leopards, and occasionally lions, which have been known to cross the channel from the mainland.

It was known, of course, that Mombasa was an island, but very few realised that it possessed one of the most magnificent natural harbours in the world, which would eventually prove the front door to the whole of Equatorial Africa, British, German, and Belgian, and a side-door inlet and outlet to our East Indian Empire : for here at Kilindini harbour 


\section{Uganda to Mount Elgon}

and township begins that stupendous monument of skill and incompetency, the misnamed Uganda Railway.

'Tis that has proved the magic wand, and changed the whole island so completely that it might now be mistaken for a well-planned botanical garden with substantial exhibition buildings.

All honour to the men who have laboured and suffered and died, some of them, to make this reception-room to our British East Africa what it is, the daintiest imaginable little coral island, with a cathedral, a newspaper, a courthouse, hotels, roads, tram-line, and railway station all its own! Indeed, there will be found every requirement for a growing and very much alive little city-every requirement but one.

How pitiable it is that almost the only flag the natives see on ships that steam into that majestic harbour of Kilindini is the French or German! Surely such a promising bit of our Empire should be linked more closely with the homeland; and perhaps at no distant date it will be done by a subsidised line of British steamers.

Mombasa, as the port of East Africa, is linked to the interior by ties other than the bridge which carries the railway. She sets the pace 


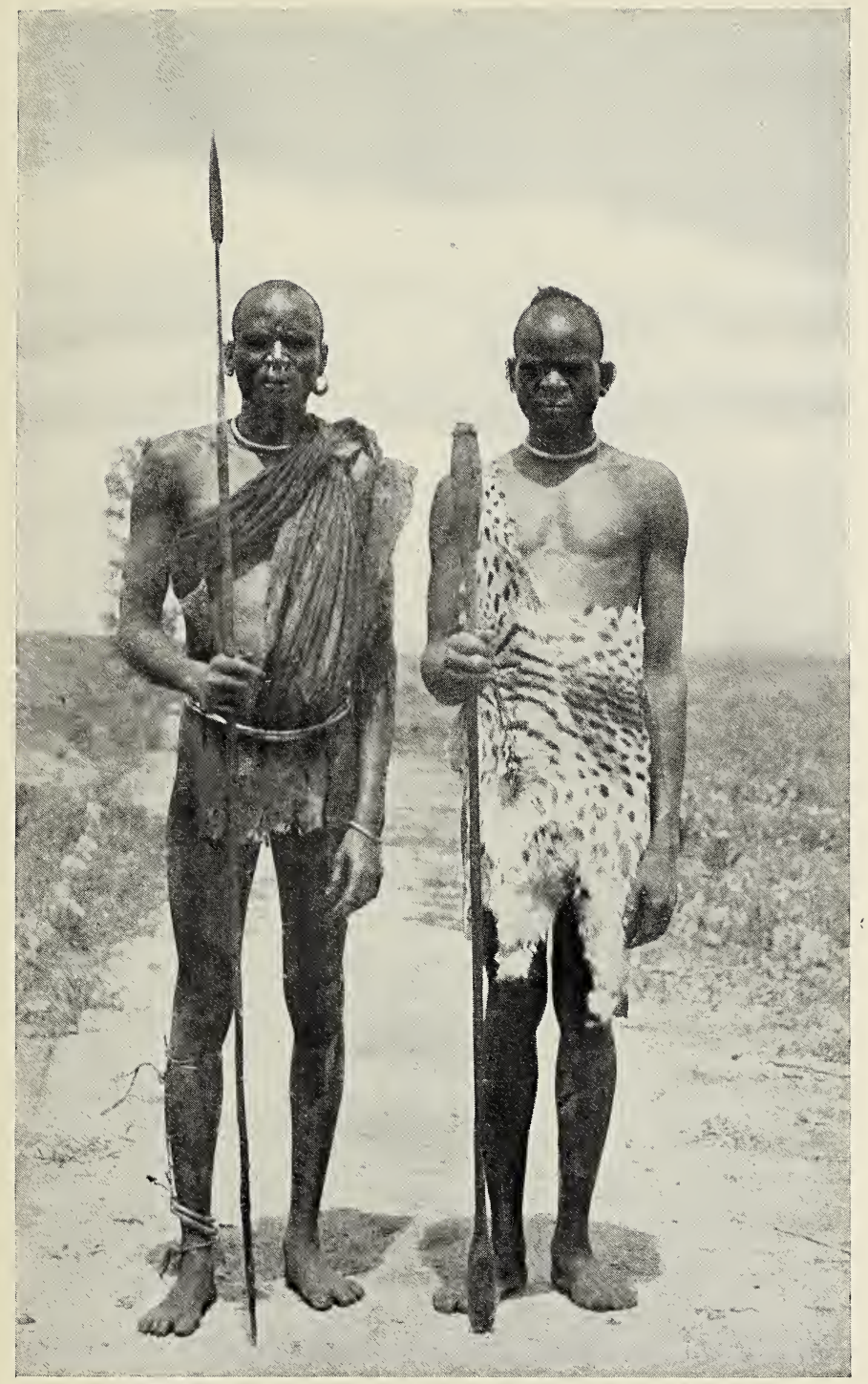

TESO HUNTERS FROM THE HINTERLAND. 



\section{The Status of Slavery $3 \mathbf{I}$}

for the hinterland, and woe betide those men who have presumed to settle inland if Mombasa is neglected. Yea, woe betide the whole country and the Government hopes if the Kilindini harbour is not developed at an early date! Not Mombasa alone, but all East Africa, is waiting for a wharf with capacious go-downs and offices. Mombasa must still go ahead for the sake of the interior, and it should be possible for every kind of inquiry to be dealt with the moment a steamer arrives.

There is time for a glance at the native town, with its low, square huts thatched with palm-leaves, ribs, or mats, to salute the little, laughing, fat watoto (children), and to see what Mohammedanism and civilisation is doing for the recently freed slaves of our Empire.

Perhaps it will be news to many that the legal status of slavery in the strip of East Africa, running ten miles deep, and which really belongs to the Sultan of Zanzibar, was only abolished on October 1, 1907. This does not mean that slavery was totally abolished, for concubines do not come under the new Regulations, but it means that a slave-owner must prove his title to the slave.

In the islands of Pemba and Zanzibar the 


\section{Uganda to Mount Elgon}

slave must claim his freedom before a British court, and prove that he has proper means of subsistence.

Not very long ago the only people who had to face the problem of freed slaves were the missionaries of Zanzibar and Frere Town; and right well they did their work, by turning out what seemed a hopeless conglomeration of humanity into useful members of society-servant-boys and girls, clerks, school teachers, carpenters, builders, brickmakers, and even ministers of the gospel.

This was a great deal to do in the midst of the very lowest type of Mohammedanism, strong chiefly because of its sensuous licence; and it will be readily understood how the sudden spurt of civilisation, the labour demands and moral evils, brought about by the building and completion of the Uganda Railway, combined to almost blot out and make impossible the work of the Christian missionary at the coast.

Yet the C.M.S. agents, under their kindly bishop, stick to their divinity school, industrial work, hospital, boarding and high schools, and, most difficult of all, open-air preaching in the market-place.

The change wrought in the lives of the people at the coast by the Uganda Railway 


\section{The Value of the Railway 33}

is stupendous, as can readily be conceived by any one familiar with the old method of reaching the interior.

Every load of from $60 \mathrm{lbs}$. to $80 \mathrm{lbs}$. weight had to be carried on the head of a porter, and sometimes a thousand men, gathered together from Zanzibar, Mombasa, and the coast strip, would boisterously start off on a thousand-mile tramp, from which many of them never returned.

The railway now carries the loads, and the men are free in a double sense-free from their old slave-owners and free to seek other employment.

Many go off into the interior as merchants in a small way, and as they go spread the superficial Mohammedanism which makes it so easily possible for a man to get rid of an uncongenial wife, and at the same time, without the faintest knowledge of the Koran, obtain some standing in the eyes of the supposedly big people from the coast.

Others are finding employment with such white men as have realised that the coastlands of Seyidie and Tanaland, though unhealthy, are really valuable, and give better return than almost any other part of Africa when laid under rubber, rice, cotton, fibre, and cocoa-nut cultivation. Perhaps nothing in 


\section{Uganda to Mount Elgon}

the world gives a more reliable and profitable return than a cocoa-nut plantation.

We have seen the indications of transition at the door; now let us go inside.

No longer the tramp, tramp, tramp, under the broiling sun, over waterless desert, through fever-laden swamp or foodless country, for we have taken a ticket for Uganda at the cost of Rs.142.5 first class, Rs.71.3 second class, or Rs.23.12 third class, and the journey which took from two to three months can now be accomplished in as many days. And what a journey! Thick forest, rolling plain, howling wilderness, pleasant pasture, hill and dale, mountain and valley, rushing river, rippling stream, roaring lion, English ox, smart official and naked savage, can all be seen in the course of one day, as we are hurried from the sea-level, up and up, to a height of over 4,000 feet.

\section{The Wanyika.}

No time now to visit the shy and weakly Wanyika people who live near the coast in their badly made houses, or to feel anything but thankful as the train rushes across the Taru Desert, with its euphorbia, mimosa scrub, aloe, thorn, and stillness of death : once the bugbear of all travellers to the interior by the British 


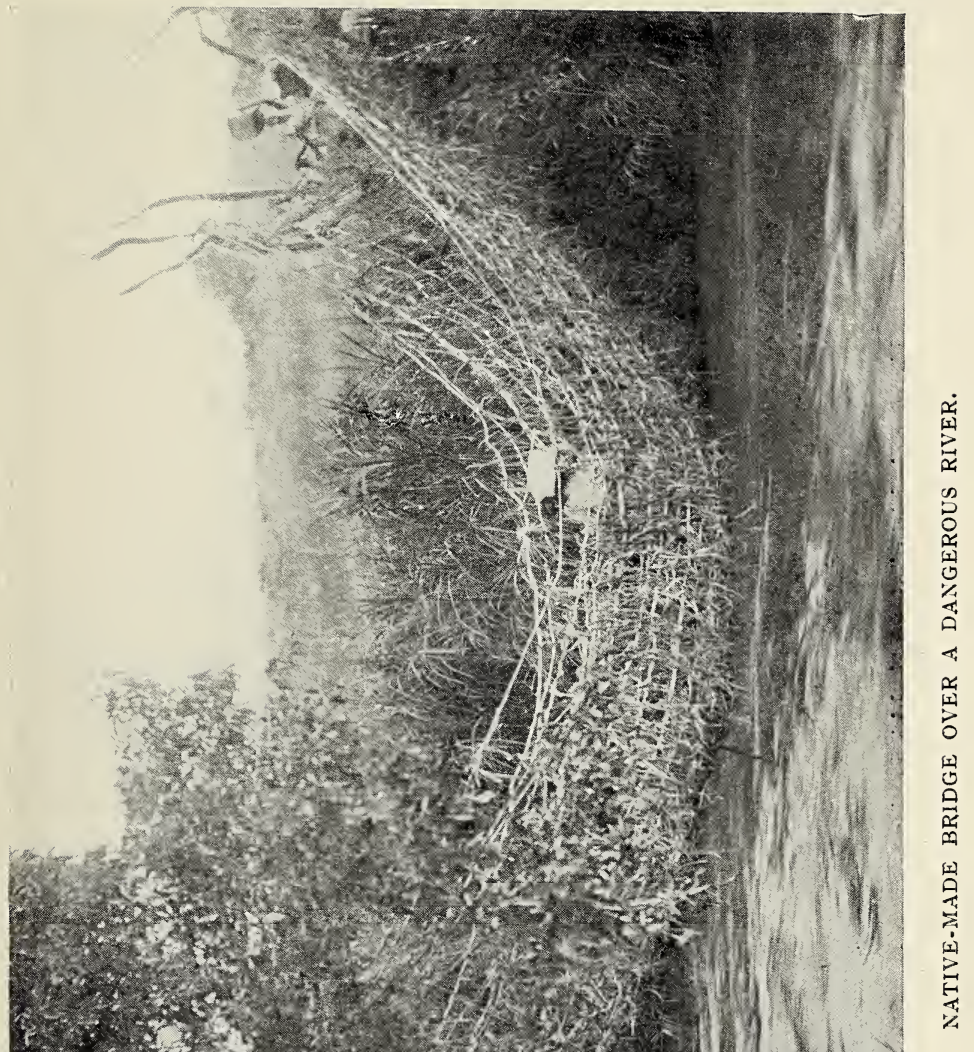

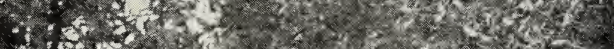

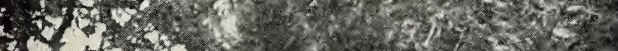

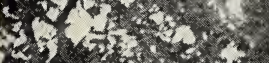

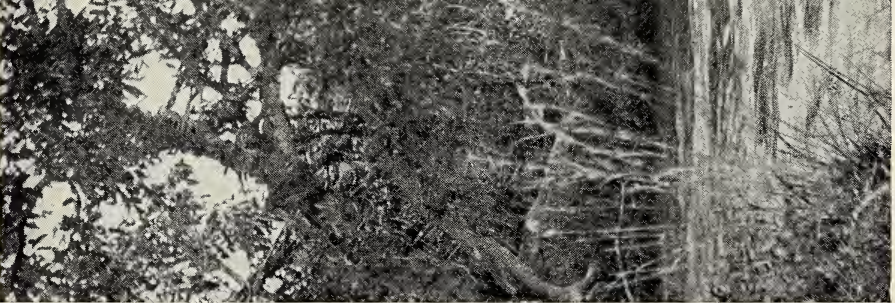

年 



\section{A Natural Zoo}

route; now not worth considering, except by fibre experts, some of whom have found it so valuable that a decorticating plant has been established at Voi.

From the railway station at Voi there is a good road practically all the way to the snowcapped and beautiful mountain of KilimaNjaro, and the country is thickly populated and well cultivated by the Wataita people, a branch probably of the Gallas.

These people have brought the cultivation of bananas, sweet potatoes, millet, Indian corn, and sugar-cane to a fine art with their wonderful system of irrigation. For ourselves, we shall rejoin our waiting train, after partaking of our first meal since Mombasa, provided at a very small charge in the Dak bungalow, quite near to the railway line.

How very different from the old days when if one wished for a steak, it had to be chosen from the innumerable herds of antelope or zebra, then shot and skinned and cooked!

Not only the Dak bungalow, but the whole country onwards from Voi, provides a treat, a feast for the eye to the lover of the beautiful and the student of nature. The Uganda Railway has not driven away the game: wildebeeste, hartebeeste, zebra, ostrich, rhinoceri, lions, may all be seen during one short run; and it would 


\section{$3^{8}$ Uganda to Mount Elgon}

be no novelty for a rhinoceros to seek the personal acquaintance of a railway inspector, or for a lion to paralyse the station staff. I well remember two such incidents, and wish I were artist enough to picture to you the face of the Britisher who, almost overwhelmed with the importance of his new position and new white suit, had started off down the line on a trolly propelled by two Indian coolies.

When I met them the rhino had, by way of protest, smashed the trolly and kept the three men some hours shivering and shouting at the top of some trees near which he quietly grazed. There was black murder in the white man's eye, a desire to avenge the loss of dignity and the suit besmeared with dirt and blood-stains, as he begged me to lend him a rifle and cartridges for a short time.

From Voi, mile 103, we continue the journey, and soon realise by the change of atmosphere that we have been ascending all the time. From 70 feet above sea-level at Mombasa we are now over 4,000 feet and again passing through a populous country, Ukamba, with its lofty hills and beautiful fertile valleys. The people, a Bantu tribe, are numerous and industrious, renowned hunters, and trustworthy guides. They are very proud of themselves, and go in for a great deal of ornamentation with beads, 


\section{A Humorous Rhino}

shells, brass, iron, and copper wire. They also file the teeth and smear the body with rancid butter and red earth.

We had a rest and meal at Makindu, mile 209; but the bracing air has made us ready for another. Our train has crossed the Kapiti Plains at a height of 5,850 feet, and every one is declaring that here is white man's Africa, the land of hope for any overflowing population. Be that as it may, I am hungry, and willing to leave such abstruse questions for another time, since the train has arrived at Nairobi, 327 miles from Mombasa, and 5,450 feet above sea-level. 


\section{CHAPTER II}

\section{THE CAPITAL OF BRITISH EAST AFRICA}

Nairobi-A bad start-Progress-Strong opinions-Knotty problems -Forcing the hand of the Administration-" "Put the native in his proper place"-The destiny of the African-Is be capable of mental and moral development? -The Governor of British East Africa-The settlerWill he ever be able to make a permanent home in the Highlands of Africa?-The evils of competition-The problems of race and colour very pressing-Locate the white man as well as the black-Is the Asiatic a "settler"? -The intermingling of the Aryan and Negro-Develop the country through the native-Organise and educate the negro-Disintegration of native customs-TaxationRearrange old tribal systems.

TAIROBI, the capital of British East Africa, 15,000 feet above sea-level, and a centre from which to hunt big game, see natives, and study problems.

The first problem is how to make the best of a bad job, for the wise man responsible for moving the headquarters of the railway from Mombasa to the Highlands was unfortunately 


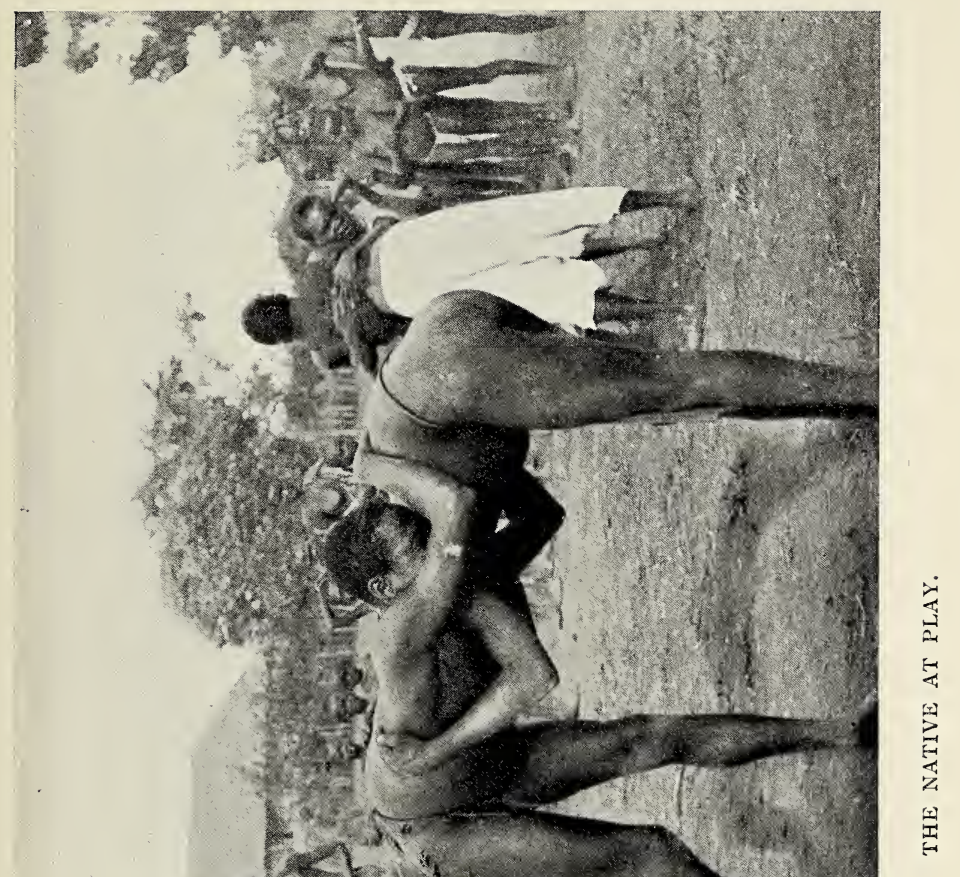





\section{A Bad Start}

also responsible for planting it in the middle of a swamp.

Thus the effort to make a beginning in the Highlands got a bad start, and might have proved hopeless but for the grit of some concerned, who have so wrought that what five years ago was a hideously bad dream of corrugated iron is to-day a very presentable AngloAfrican town. There is an Anglican church, Roman Catholic chapel, a bank, a couple or more really good hotels, a post office, stores of every description, a well-made main road, rickshas plying for hire, some slight attempt at drainage, and a market that really does credit to the place.

Indeed, there is a great deal more than might have been expected in so new a town, and a great deal more than is good for it, for from the beginning Nairobi has been blessed-or cursedwith men holding strong opinions.

With the building of a house for the Governor began the question of whether Mombasa or Nairobi should be the capital, and since that time it is somewhat difficult to decide whether population or opinions increased more quickly.

The strength of the latter has certainly developed until the tone of one local rag might sometimes be mistaken for an outspoken American. The human element at Nairobi is the one 


\section{Uganda to Mount Elgon}

to be considered, and the one that ought to be considered now if we do not wish to reap grievous troubles in the future.

It seems almost incredible that whilst here in England, within a comparatively small area, the cry of needy thousands can hardly be heard, in East Africa some five hundred and fifty men are making so much noise that the House of Lords gives pause to listen. Were it not absurd it might be serious, yet no doubt behind it all lie principles serious enough.

Is "the Colony of British East Africa" a misnomer? If not, who are to colonise it? Well, since the climate is very similar to Southern Europe, the soil rich, fertile, and well watered, European vegetables, fruit, cereals, sheep and cattle already doing well, the answer seems to be, "White men." And this is the only answer in the mouth of the men in and around Nairobi : the man who is doing well on his farm, and really ought to be encouraged, and the man who has never done well anywhere, but mysteriously turns up in every new African town to hang round the billiard saloon, live on the newest hotel venture, and give gratis his opinion on law and order-a disgrace to his countrymen, a danger to every new colony. There is also another being who answers, "White men!" in a particularly loud voice, 


\section{The Right Kind of Settler 45}

namely, the man who hopes to grab as much of the best land for the smallest possible outlay, and sell it at a big price to settlers. Both the latter are men who ought not to be tolerated in a colony like East Africa, and if they could be dismissed I do not think the other would be a difficult person to understand. He is the man who wishes to do the best for himself by honest hard work, and curiously enough he is seldom heard prophesying that the country is going to the dogs. $\mathrm{He}$ has built his little house and is far too busy in town or country developing his own business to give advice as to how to make money, run missions, and govern the country.

Still, even he will not believe there is any but the one answer to the question about the East African Highlands, in spite of the fact that there are five times more Indians and twenty times more natives than white men within a radius of a mile from where he stands.

The natives claim the soil; they have lived there for ages ; they are not the idle, good-fornothings we sometimes hear them called, and naturally they are surprised when told that the big white man, the Governor, has sold their land to the lesser white man, the settler, who may or may not be disposed to allow the African to remain on the land. 


\section{Uganda to Mount Elgon}

One case was brought to my notice where the buyer impudently asked-perhaps out of bravado or wish to chaff the official-if he had a right to shoot on sight any native he caught on his property.

The chaff indicates the trend of thought; not that such men would shoot the native, but that the native ought to be cleared away at the will of and to make room for the white man.

I need not here refer at length to the endeavour made some time ago to force the hand of the Administration on the native question, by unlawfully whipping some servant-boys in the public street of Nairobi immediately in front of the magistrate's office; but I do say, "God help the Governor" of such a country at such a time.

To "put the native in his proper place" simply means, to many who are interested in the question, to put him where he can most easily be called upon by the white man for any assistance in seeking to make a fortune; to be content to acknowledge himself accursed as a child of Ham; and the more accursed the more he strives to remove any indication that he is different to other men.

That the African may have a destiny high and noble, a life to develop on the soil where 


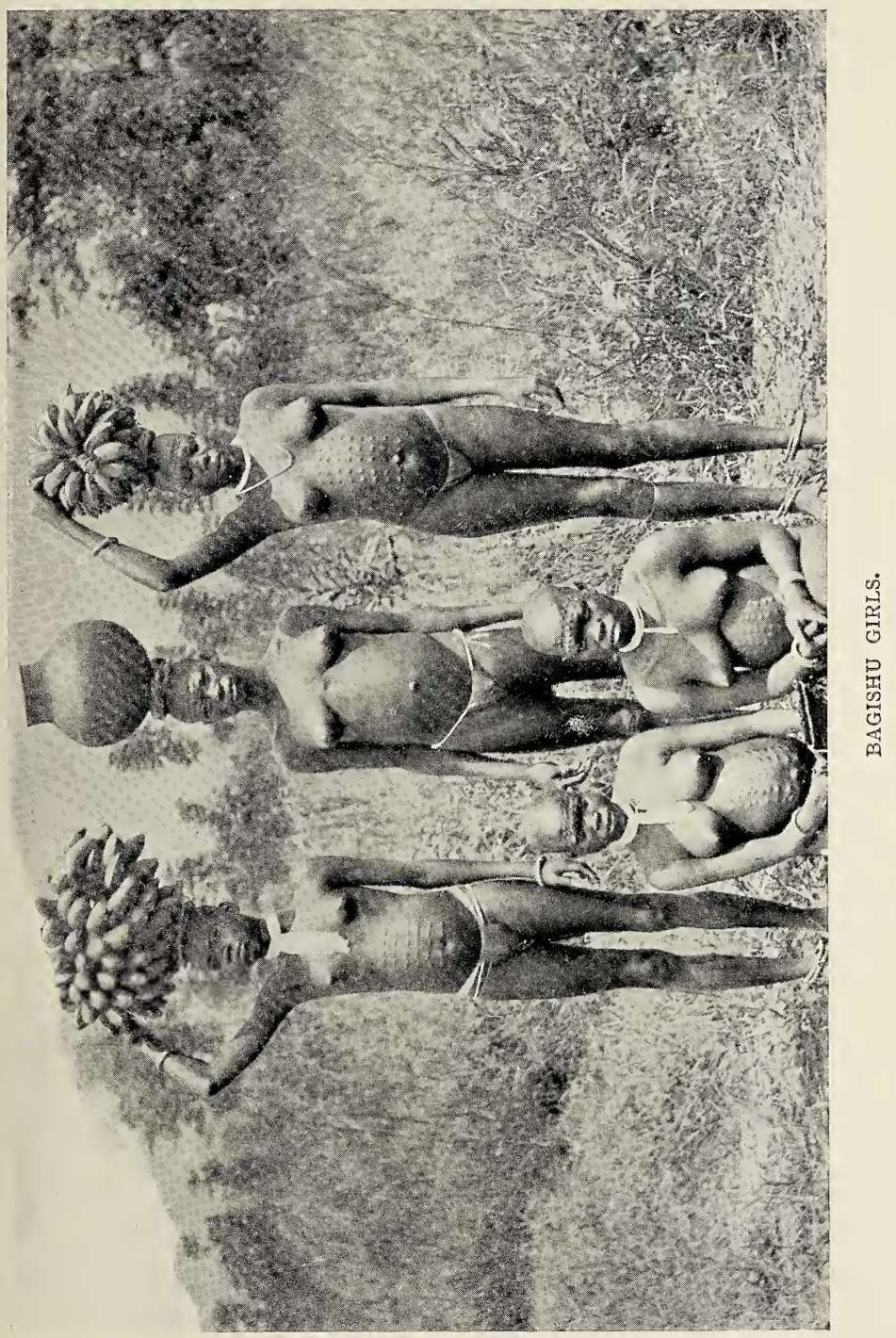





\section{Problems of Black and White 49}

found, of course under a more fostering care and tender mercy than those of the man hastening to be rich, has never been considered by many: indeed it is argued that he is totally incapable of mental and moral development; but only a very short journey from Nairobi is necessary to refute such an opinion.

Fortunately the present Governor of British East Africa is a man worthy to hold the position, and he is capably supported by his staff, who recognise their great responsibility to the native sons of the soil.

They realise that they are face to face with stupendous problems which can only be solved by patience, tact, forbearance, and strong common sense, and are not willing to be unduly pushed into one line of action, bullied or frightened into another.

I deeply sympathise with the man who, in the homeland, has turned his little all into capital, and, beguiled by land speculators' tempting advertisements or lectures, has gone out to East Africa, only to find that there are so many difficulties to be overcome before he can settle down, that his capital has vanished.

He is appalled at the length of time necessary to secure land settlements; the unsettled condition of the native question, the incongruity of 


\section{Uganda to Mount Elgon}

an English colony in Africa administered under the Indian Penal Code, and administered by officials who have had little or no experience of such administration so far as white men are concerned. The tendency to petty officialism under such a code galls him frightfully, and he gives up in despair to join the ranks of the malcontents. How well employed would the Colonists' Association be were it to meet the Governor and thrash out once for all the answer to the question at first propoundedIs "the Colony of British East Africa" a misnomer? If not, who are to colonise it? This question once settled, we should have fewer men in East Africa embued with Carlyle's false idea that "the fundamental question between any two human beings is : Can I kill thee or canst thou kill me?"

Comparing the negro and the white, there is no question as to who is best fitted for the country and which population will grow most rapidly. The negro is at home, the white is not; and, in spite of the fact that homesteads have appeared and some progress made in cattle-ranching, it is quite an open question whether the white man will ever be at home in the African Highlands; that he will ever be able to build up here, under the direct rays of the Equatorial 


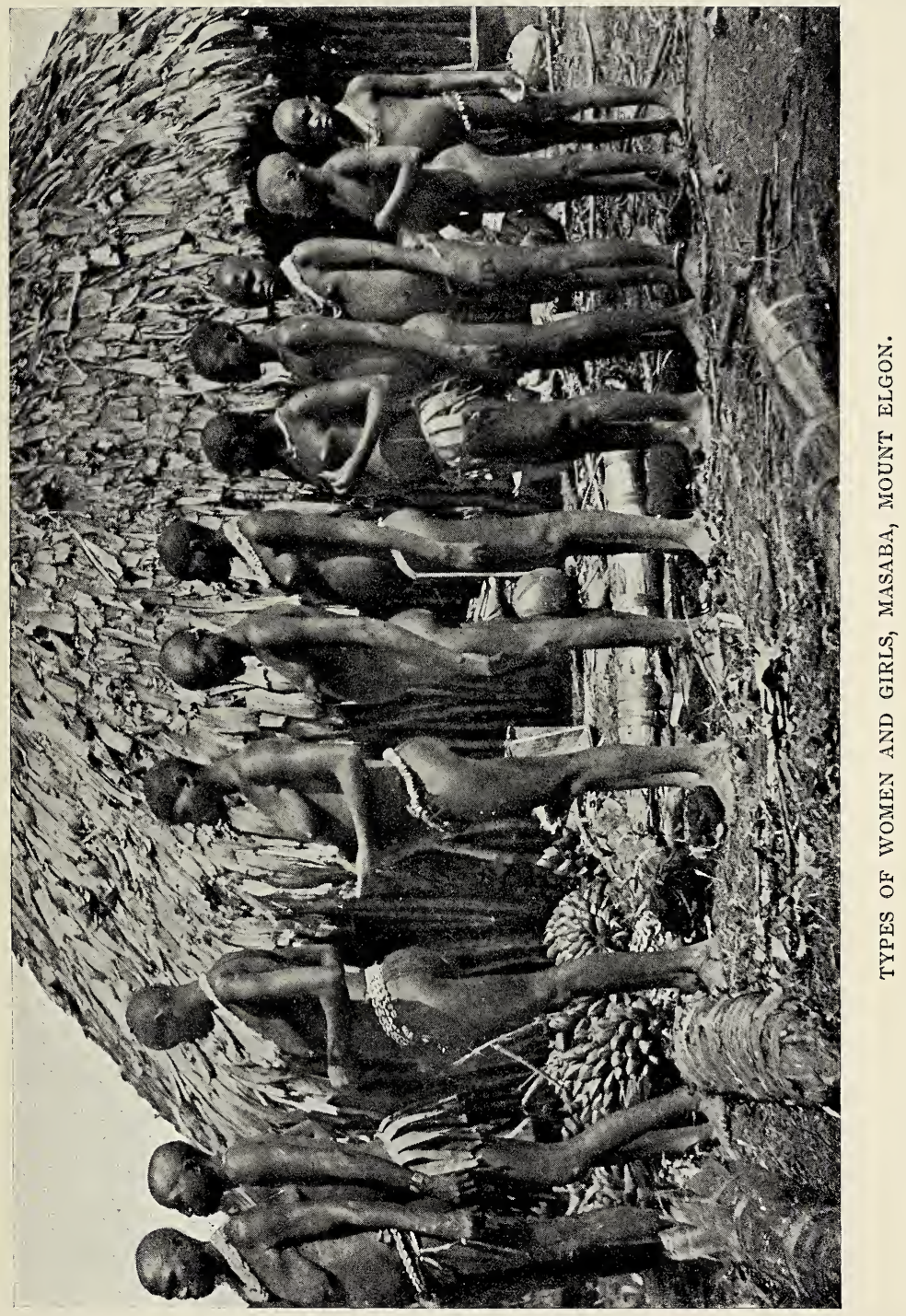





\section{Wanted, A Master Mind 53}

sun, a strong, contented, self-supporting, permanent, white community.

Take away from Nairobi the official life-civil and military-the parson and priest, the railway staff, general agents, store- and hotel-keepers, the parasites and loafers, and what have you left? Well, the town will have ceased to exist so far as the white man is concerned; and in the country, on farm and ranch, will be one or two-not more-doing reasonably well.

The evils of competition are too manifest in such a small community, and men are really buying and selling each other, did they but know it.

So long as four millions of blacks are willing -according to some ideas-to remember their right place, and remain hewers of wood and drawers of water for the small, very small, handful of whites, the "lucky" few will be content; but the colony will still remain undeveloped, the native problem unsolved, and a large section of the whites as discontented as ever.

For the sake of all concerned, let me reiterate that now is the time for some master-mind to grip the problems of race and colour, right and prior-right, in our East African colony.

Is it not possible to offer the white colonist and settler a better chance, by setting apart a 


\section{Uganda to Mount Elgon}

large portion of the very best land with the most suitable climate, and reserving that, town and country, for the white man only, and administer it under white man's law? Of course it would not be possible for the man with influence to buy the lot, or even the best; but, first come, first served, if-and the if is a big one-he be a worker.

Innumerable questions surge up at such a proposition, and undoubtedly great difficulties would have to be encountered and overcome. Would all the labour be done by whites? \&c., \&c., are questions that would naturally solve themselves, once the principle was laid down that within a certain area was situate and constituted a colony for white men only.

Such a policy would leave the Government free to deal with the next two most pressing questions-the African and the Asiatic.

To take the Asiatic first. No one conversant with Sir H. H. Johnston's purpose and policy, as laid down in his books on British East and Central Africa, can fail to understand that India and Africa are closely allied, in the minds of English statesmen at any rate. And the most superficial observer in British East Africa will notice that the Indian is a factor to be reckoned with in practical politics. Still, I very much 


\section{Asiatic Visitors are not Settlers 55}

doubt whether he will ever be in Africa that important factor so many prophesy.

The Indian is the most wonderful merchant in the world, not excepting the native of Uganda. He will come to Africa without a single rupee, get employment from one of his compatriots, live on a few grains of rice per day, buy native hoes with his earnings, and with these disappear into unknown regions to turn up again and again with loads of skins and hides, until, tired with journeying, worn out with malarial fever, and longing for home, he makes his way to that side-door, Mombasa, and ships for Bombay.

Can this man in any sense be called a settler or colonist? and are not all the others-merchants, clerks, artisans, and coolies-much the same? The Money Order Department of the Post Office supplies the answer by telling us of the enormous amount of money continually transferred to India by these visitors.

That India has a part to play in our East African Empire is undoubted, but that Providence has arranged that part to be the intermingling of the Aryan and Negro races may be gravely questioned.

The great bulk of India's population live in villages and till the soil ; these, if any, are likely to feel the pinch and require room for expansion. But do they require it? or, what is more 


\section{$5^{6}$ Uganda to Mount Elgon}

to the point, do they desire it? If so, they have not sought British East Africa as a new home waiting to yield them its harvest.

This being so, we must look elsewhere for the men who will by manual labour develop the natural resources of our colony; and right here comes in the opportunity of the Administration to so distribute, organise, and educate the native element that, with the help of the Asiatic, with whom in many ways the white man cannot compete, we may at once begin a possible and hopeful evolution rather than continue the present chaos, that must inevitably lead to revolution.

"Organise and educate the negro!" Is that possible? Speaking from my own and the experience of many more qualified to judge, I say quite possible, and the sooner it is taken in hand the better. Up to the present moment the whole work of education has been done by missionaries, encouraged but not helped by Government, and the results have been little short of marvellous; but the coming of the Uganda Railway and messengers of civilisation-some good, many evil-before the vast majority of natives had been the least prepared even by Christian missions, have thrown them off their balance. They do not quite realise what part they have to play in the drama of development; and they 


\section{Organise and Educate}

feel like boys who have been chased away from their playground, but hang round perplexed, ready for any new game, harmless or dangerous.

This latent power for good or evil surely appeals to England with as much force as the power allowed to run waste over the Ripon Falls; and one cannot imagine it will appeal in vain.

The white and Asiatic elements in British East Africa are both too small and uncertain to justify the shaping of legislation to suit them only; they are both, as a whole, too content to live on and by the native. And the native, whose appetite for progress has been whetted, if only by the desire to obtain a shirt or waistcoat, must have his attention turned to the real source of wealth-the cultivation of the land for more than his own needs.

By the introduction of civilisation we have begun the work of disintegrating the present social conditions of the African; and it seems to me a very serious thing to allow this disintegration to go on, whereby all the power of chieftainship is lost, everything understood as government annulled, and the native actually forced from the land of his fathers and left a huddled, disorganised, and confused mass.

Hut-tax and poll-tax may prove an incentive to force a portion of the disorganised mass to 


\section{$5^{8}$ Uganda to Mount Elgon}

seek employment from the settlers, but what of all the others? We cannot, surely, suppose that the question will be settled by declaring a certain portion of country " reserve," from which a native is not allowed to pass without a ticketof-leave.

Educate, educate, educate! not by turning loose among them so many schoolmasters, but by organising them-on their own clan system preferably-under trained leaders of men, practical agriculturists and stock-raisers, who might so use the chiefs and as much as possible of the old tribal systems, in order (a) to rearrange each tribe under the changed circumstances; $(b)$ to settle them on new land if necessary, giving them plenty of room to expand, no leave to be idle, but every encouragement and help to develop the resources of their land along lines laid down by their instructors. Do for each large native community what the experimental farm at Naivasha does for the white man, and erect at once industrial institutions for the training of artisans who will supply the need of black and white alike. I have no doubt but that the missionary will be only too glad to be called upon to supply other education for which, apart from his evangelistic work, the Government ought to pay him.

Along such lines there is hope, I believe, for 


\section{Use Hopeful Material}

all, but more especially for the man likely to be forgotten until he becomes a burden, intolerable even to himself-the native of British East Africa-at whom we shall take a closer glimpse before rejoining the train for the Lake. 


\section{CHAPTER III}

\section{THE NATIVE}

Four millions of natives-The Swahili-Arab and AfricanArab influence - Swahili nature - "Black ivory"Mohammedan missionaries-Primitive tribes-The Wakamba-Ideas of beauty-Religion-The WakikuyuTheir industry - Ornaments - Polygamy - Unrest-The Masai-" Fierce nomadic warriors"-Nilotic negroesPastoral people-Dress - Warriors - Houses - Women's work-Engaged-Ear-rings-Sacred objects-The Great Spirit-A problem.

П $\mathrm{HE}$ problem of four millions of native 1 Africans begins at Mombasa and spreads itself over the whole of British East Africa, until we reach Lake Victoria.

\section{The Swahili.}

At the coast we have that hybrid race already mentioned, the Swahili, or coast people-a race brought into existence by the intermarriage of Arab and African. 


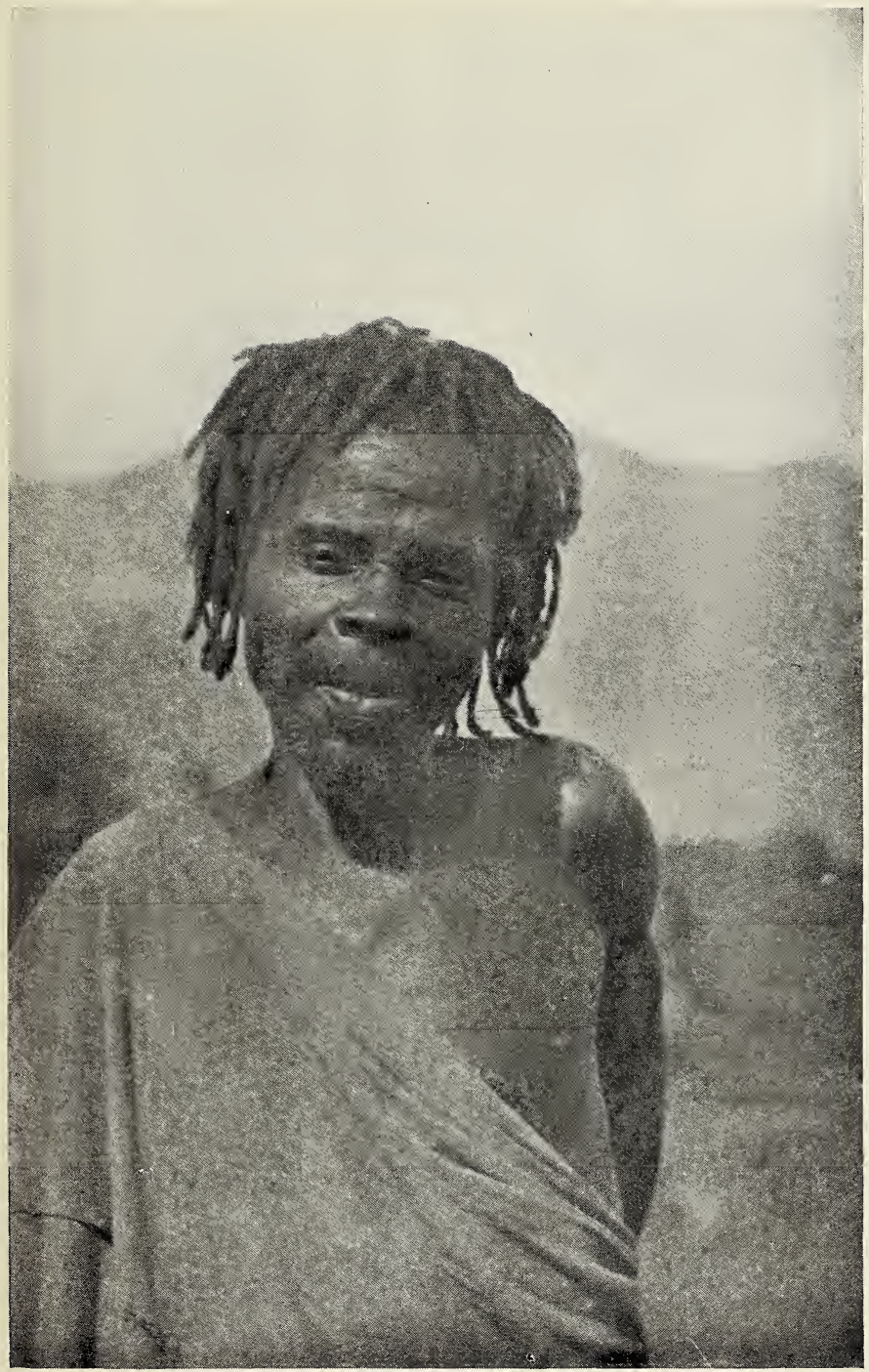

A HARD DRINKER AND MEDICINE MAN, $6 \mathrm{I}$ 



\section{The Swahili}

Others have dealt with the death of Portuguese and the growth of Arab influence on the East Coast, so there is no need for me to do more than mention the fact-a fact that has had a great influence, not only on the coast life but throughout the whole of Central Africa, for the outcome has been a people and a language. The people, deriving their name from the Arab equivalent for coast, are liberally endowed with Ishmael's wandering propensities, and have become the merchants of the Equator; and it seems difficult to believe that the innocentlooking individual, now buying or selling a donkey, was equally good at bargaining, only a few years ago, for men and women; and that the jester was right who said that Swahili is derived from sawa hila, which may be interpreted "All same cheat."

Such, however, was the case; the whole of the East Coast slave-trade was carried on by these people until stopped by the power of England.

Curiously enough, whilst the Arabs were able to imprint their personality and religion upon the native, yet the negro element was too strong for absorption, physically or linguistically. The negro type, drawn from many branches of the Bantu race, has held its own, and even forced a Bantu language upon its conquerors or masters. 


\section{Uganda to Mount Elgon}

Pure Arab merchant and hybrid Swahili use the same language, and have made it, by their many expeditions into the interior after "black ivory," the lingua franca of Equatoria. The peculiarities of a Bantu language are dealt with in Chapter XV. Such a race as the Swahili, with its negro propensities and Arab cuteness, has great influence as a Mohammedan missionary among the primitive tribes. It has also added very considerably to the difficulties of those working at the coast amongst freed slaves.

\section{Primitive Tribes.}

The primitive East Coast peoples, immediately in touch with Mombasa, are the Wanyika and the Wagiryama; few in number, poor in physique and martial ability, very superstitious, but also very industrious in agriculture.

Between the Giryama country and the Somali country, north of the river Tana, dwell the shy and cowardly primitive Wapokomo people, whose customs and manners are very similar to those of the Bantu Kavirondo, which are dealt with later on.

One of the strongest and most interesting peoples touched by the Uganda Railway is the tribe known as the Wakamba, dwelling in the country which stretches from the Tsavo River to the Athi plain. They are a brave and indus- 


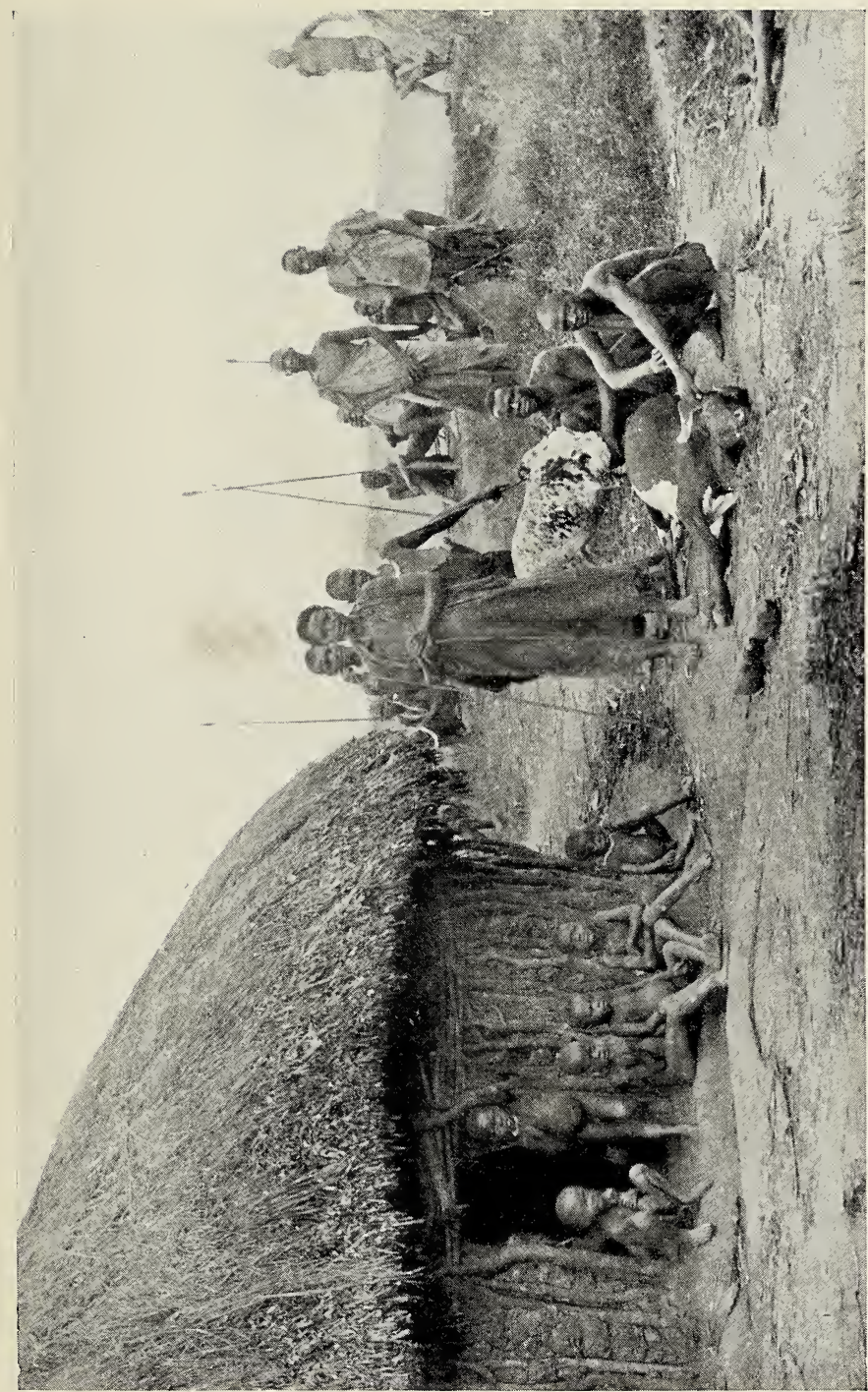

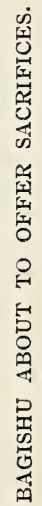





\section{Primitive Tribes}

trious people, who would, I feel certain, give a good return for any interest taken in them. Fond of cattle and agriculture, they are also good at making a bargain, and have been more helpful in provisioning passing caravans than perhaps any other inland tribe.

Though not aggressive, they have held their own against would-be oppressors, and for years past have organised their own caravans to carry trade-goods to the coast.

They are not very particular about the amount of their clothing, but are very fond of iron and brass wire, iron chain, and ornaments made with beads and shells. They also seek to add to their beauty by filing the incisor teeth.

The men, armed with bows and poisoned arrows, spears and swords, are mighty hunters, and renowned trackers of game, whilst the women are the most wonderful carriers in East Africa. The load of wood, flour, grain, bananas, or babies, is fastened on the back in the hide sling which hangs from the forehead.

Like most pagan Africans, the Wakamba have but a vague idea of religion, believing in the power of evil spirits, to whom they make meat and drink offerings, and against whose influence they carry charms. 


\section{Uganda to Mount Elgon}

Their custom of circumcising does not seem to have any connection with religion.

\section{The Wakikuyu.}

By far the most important tribe in British East Africa is the Wakikuyu : a strong, industrious, and warlike race of Bantu people, related more probably to the western branch of Equatorial negroes rather than to their eastern neighbours, the Wakamba.

These really are the people whose presence near the capital, Nairobi, occupying as they do the beautiful and well-watered country between the river Kidong and the Lossogurti Escarpment to the north of Mount Kenya, has forced the question of white and black, right and priorright, to the front.

Kikuyu country is situate at an elevation of from 4,500 to 6,500 feet, and is in climate quite sub-tropical. There are evidences that at one time it was a vast forest, which the natives have cleared in order to carry out what is, compared with other native efforts, an advanced system of cultivation, on the best soil in British East Africa.

Although renowned for treachery and turbulence-due, no doubt, to the many attacks made upon them by their cattle-loving and 


\section{An Industrious People}

raiding neighbours, the Masai-the Wakikuyu are admittedly a hard-working and industrious people, quite unfamiliar with famine. They grow bananas, sweet potatoes, sugar-cane, yams, peas, beans, millet, gourds, tomatoes, and tobacco. They are not rich in cattle-again, no doubt, because of the Masai; but under the Pax Britannica their herds are already on the increase. They are also bee farmers, and hives are to be seen in every tree.

Between the Wakikuyu and the Masai there seems to have been constant warfare, yet, curiously enough, the Wakikuyu have to a great extent copied dress, customs, and arms from the Masai.

The men are content with a goat-skin for a garment, eked out with the covering of a fatty red mixture of castor-oil and earth with which they smear themselves.

The women are more liberally clothed in skins hanging from the waist and shoulder, the number of which vary according to the season. Indeed, except in features, the appearance of a Kikuyu woman resembles very much that of her Masai neighbour, because not only clothing but Masai ornaments have been copied. Ears are pierced and loaded with iron rings, chain, beads, gourd ends, pieces of wood, and-since the advent of civilisation-empty jam tins are 


\section{Uganda to Mount Elgon}

seen everywhere fixed in the extended lobe. The men wear a peculiar armlet on the left arm, made of ivory or wood in the shape of a merry-thought bone.

Beads, of course, are used, not only as currency, but for ornamentation; and some very pretty girdles are seen, made of beads sown on to leather, and worn by men and women.

A snuff-box is a usual item of a gentleman's wardrobe, for snuff and tobacco are much appreciated. A Kikuyu man is armed with a spear, sword, knobkerry, sometimes a bow and arrows, and a shield made of buffalo hide, after the Masai pattern, and marked in a similar fashion with a clan mark picked out in colours.

Married as well as unmarried men are warriors, and this being the case, most of the work is performed by the women, who age rapidly.

Like other native races, the Wakikuyu practise polygamy, and wives are bought with cattle; the newly married wife being brought to her husband's village with a semblance of force. She now discards the many ornaments used to attract lovers, and settles down in her own house to lead an industrious and wonderfully moral life.

The unmarried men and the unmarried girls live in houses set apart for them, supposedly 


\section{A Transition Period $7 \mathrm{r}$}

under supervision, but there is a great deal of free intercourse between the young people.

The native system of government has scarcely advanced beyond the patriarchal stage, and in many respects they are a people similar to the primitive Bantu we shall meet later on.

Such people are worth considering from an economic point of view, and with them the white administrator might at the present moment do anything.

The idleness and unrest are due to transition; for, as we have seen, clan ties have been loosened, patriarchal authority has had to give way before the Indian Penal Code, and the natives' sociological ideas have been uprooted and overthrown. Before he again enters Utopia there must be a period of individuality, brought about by the kindly help and organisation of the English Government, through such practical education, training, and industrial enterprise as can be given, for the purpose of developing character to rightly use responsibility and opportunity.

\section{The Masai.}

A somewhat less hopeful but more interesting people are the Masai, who for many years were as an impassable barrier to those who 


\section{Uganda to Mount Elgon}

wished to explore British East Africa. "Fierce, nomadic warriors" was all the description we had of them until the Scotch traveller, Joseph Thompson, gave us a closer view in 1885; and even then those three words seemed to so clearly describe them that there was no anxiety on the part of the travelling public to make a closer acquaintance.

Since that time much water has run over the Ripon Falls, and the more dangerous faculties of the Masai have been so paralysed by the magic of the white man that the most timid inquirer may now approach them with safety.

The Masai are not a Bantu people, but a branch of the Nilotic negroes. Originally in two divisions, each under its own medicineman, they are now divided into various sections and occupy the country that stretches from Mount Kilimanjaro, in the south, to Lake Baringo in the north.

A purely pastoral people, their custom was -until placed in reserves by the British Government-to move from place to place in search of suitable grazing ground for their vast herds of cattle. Incidental of such nomadic life, it was no uncommon thing for one section to trespass on the ground of another section, with the result that war was declared 


\section{Masai Warriors}

-actually declared, in civilised fashion, if such a statement is not utterly incongruous. Treachery was only permissible when dealing with those who had not the honour to be Masai.

A Masai, as a rule six feet or more in height, straight as an arrow, splendidly developed, without an ounce of spare flesh on him, his head well balanced, and of a shape quite different to the Bantu tribes around, high cheek-bones and beautiful nose, is a sight well worth seeing, and suggests great latent power and possibility.

This striking individual-the more striking because of his headdress of ostrich feathers, collar of Colobus monkey-skin, with the long white and black hair attached, and his whole body smeared with a greasy red paint that makes him look really formidable-is one of the El-moran, or warriors, and is therefore unmarried; for the native political organisation is such that when a man marries he ceases to be a warrior.

The section occupying a particular district is subdivided into clans, and on the large shield of the warrior is clearly marked the heraldic device of the clan to which he belongs. Each clan has its spokesman, medicine-man, and political chief. Then come the two divisions 


\section{Uganda to Mount Elgon}

of the adult male population-the El-moru, i.e., the quondam warriors who have become benedicts, and as such rank as elders, responsible for the good conduct of their kraal, and the El-moran, or warriors, already described.

The houses are of the rudest possible character, made of bamboo and wattles, twisted and bent into a tunnel-shaped object some three or four feet high, then plastered over by the women with mud and cow-dung. These huts are built in a circle, and if they are to be occupied by the El-moru a strong fence is erected; but if the kraal belongs to the El-moran there is no fence, for as "Britannia needs no bulwarks," so the Masai warriors require no other protection than their own watchfulness.

When a move is necessary the women are responsible for packing all household utensils and the bamboos, \&c., used in hut-building, on the donkeys, and transporting them to the new grazing ground, whither the men have driven the cattle. In a Masai home the infants, male and female, are called En-gesa; when boys can walk they are En-aiok; after circumcision they are El-barnode, whilst girls at the same stage are En-doya.

When the males are old enough to carry arms they cease to eat any vegetable diet, and live on beef, blood, and milk. They move 


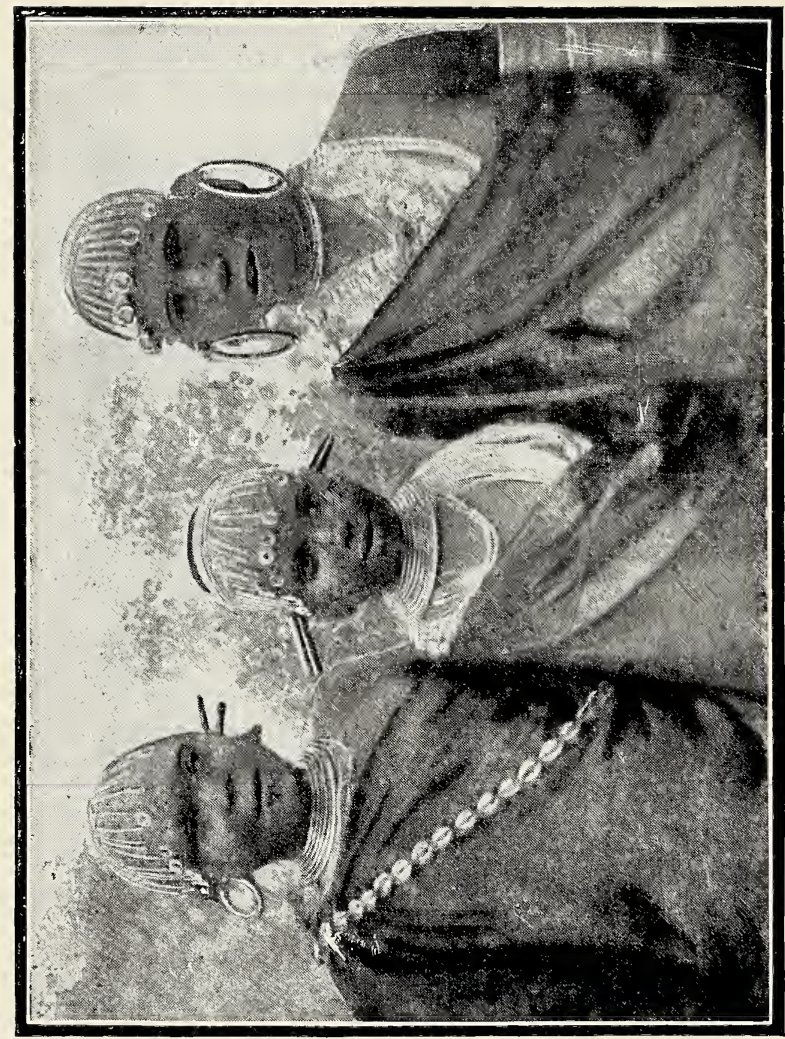

苟

=

동

4

0

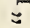




\section{Good-looking Girls}

into the kraal of the El-moran, and there live a life of free love with the unmarried girls, who, in spite of the fact that the custom is an old one, are nevertheless punished if they become mothers. The great wonder is that these girls are able to settle down after marriage to a fairly moral life.

An engaged girl is easily known by the length of her hair and by the band round the head with cowrie shells hanging from a number of strings, like the married woman of Palestine with her pieces of money hanging in much the same way.

At marriage the head is shaved, certain ear ornaments discarded, and the married woman's skin garments adopted.

The girls are quite good-looking and graceful; but many seem to be actually deformed owing to the pressure on arms and legs of the heavy spiral coil of iron wire.

The ear has been chosen by the Masai as the chief member for ornamentation, which means, in some cases, the most frightful disfigurement. The lobe is pierced and then extended until it is made to take a piece of wood varying in size from two to six inches in diameter.

There are various forms of salutation used in the country, one at least not acceptable 


\section{Uganda to Mount Elgon}

to a white visitor-namely, that of spitting. The Masai are quite adepts at sending out the saliva, through the notch filed between the two upper incisors, and of course you must take the salutation in the spirit in which it is given.

The married women do some very pretty bead-work and ornament the gourds in which the milk is kept. Milk is accounted sacred, and may not be boiled; and no stranger is supposed to receive it either for pay or as a present, but sometimes one has been able to buy a little from a soft-hearted lady.

Grass also is a sacred object, and, when held in the hand, a sign of peace. A visitor is receiving the most cordial welcome when the Masai touch him with grass.

Ngai is the great spirit of this nomadic people, and to him, who dwells, they say, in the great mountain in the south, they continually pray for help and guidance.

A strange people indeed, and one not easy to deal with as part of the problem before us. More interesting than the Wakikuyu, but not so hopeful, because they are pastoral and not agricultural. Yet even with a pastoral and cattle-loving people like the Masai, there is reason to believe that a little expenditure and careful organisation will turn them into settled 


\section{Native Ranchers}

and permanent ranchers, willing to sell their improved stock at the improved prices offered.

Of course, with such a proposal I am knocking right up against the one or two rich ranchers who at present have it very much their own way, and would probably not care to have the native organised, educated, and helped by Government to beat them at their own game. Yet it seems to me far more incumbent upon the Government to develop the native human being, and, by so doing, develop land and stock, than to neglect the human element and hand over the land, that has been the grazing land of the Masai for ages, at a nominal figure to one or two rich Englishmen, or to a syndicate, for the purpose of -well, not for the purpose of developing the native.

Though tempted to leave the railway and push northward beyond Lake Baringo in order to visit the Suk and Turkana peoples, we must not do so, but take the next train and move westwards to the Lake. 


\section{CHAPTER IV}

\section{FROM NAIROBI TO LAKE VICTORIA}

The most beautiful country-The great "fault"-The Mau Escarpment - Giant timber-A serious rainstorm Poisoned arrows-Nandi troubles-A caravan cut upPort Florence-Kavirondo peoples-A surprise-The tropics indeed-The C.M.S.-The power of example-The sight of a lifetime-The day of opportunity for the Christian Church-Education or Evangelisation?

T EAVING Nairobi we push on to the Lake through the most beautiful country of British East Africa. We cannot leave the native question behind, for our very train has been obliged to carry armed Masai to protect its passengers from disloyal natives that may be met with.

Having crossed the wonderful Meridional Rift, or great "fault" as geologists and miners would term it, which stretches almost the whole length of Africa, and here at Kikuyu falls almost sheer to a depth of 1,440 feet, we are soon passing 


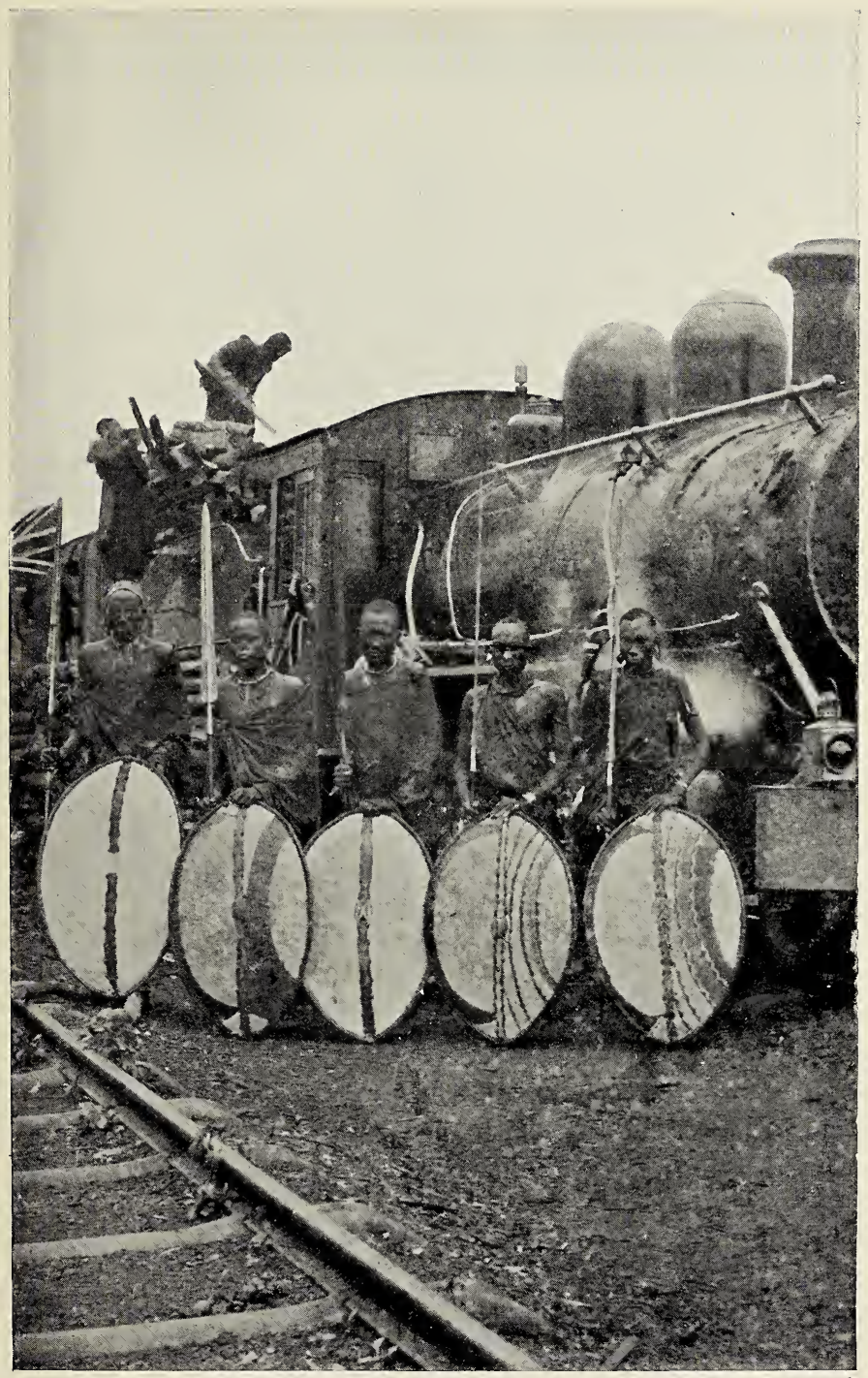

MASAI WARRIORS GUARDING A TRAIN ON THE UGANDA RAILWAY. 



\section{A Deadly Downpour 83}

over the Mau Escarpment, with its mighty forests of giant timber that patiently wait for the axe and saw and ingenuity of man or enterprise of the Government, to turn the best of the timber to better account than fuel for the iron horse, and from the rest provide that fuel more easily and cheaply than at present.

Already some enterprising individuals are working in a small way, with the result that almost every article of furniture may be bought in Nairobi in a style and at a price that will compare with anything in England. What a different journey from the one I took in 1895, when it was plod, plod, plod up hill and down dale, in sunshine and shower. One shower I remember overtook us on this very escarpment, and I don't suppose it will ever be forgotten by any of the party.

We were descending Mau on the westward side and had almost reached a convenient camping-place when it began to rain. The cold was intense, the path, bad at any time, became slippery and difficult to negotiate; the rivulets became mighty torrents, and the porters were in despair. We coaxed, we threatened, we helped with loads, and carried men; but I believe a dozen succumbed as the result of that downpour.

From such a recurrence as that the railway 


\section{Uganda to Mount Elgon}

has delivered us, and I, for one, am grateful. The Dorobo people, with their poisoned arrows, are still in the forests, but no longer have we to keep our men in close order lest a stray arrow should find an untimely resting-place. The engine pants and puffs and snorts, and eventually reaches the highest point from which we run down at an increased speed into a totally different climate.

We have reached what for purposes of administration is called the Province of Kisumu, through which the railway was hurried to the Lake by a short cut when the patience of the British taxpayer had almost reached its limit. En route it taps the countries of Nandi, Lumbwa, and Kavirondo.

For some time past the Nandi people have given considerable trouble, and at one station there was gruesome evidence of their having paid a visit just before our arrival. Our Masai guard seemed quite disappointed that they had missed an opportunity of displaying their powers; but the passengers were too fluttered by the sight of one dead man to wish for more bloodshed.

It reminded me of my first visit to the Nandi country and of a ghastly experience of their bloodthirstiness.

Our caravan of some six hundred porters 


\section{A Ghastly and Painful Sight 85}

was delayed at the coast for a short time : and a small caravan of some thirty mail-carriers was despatched in front of us. When we reached Eldoma Ravine, a wounded Swahili crawled into our camp and told a tale of awful butchery. He, with the other mail-runners, had passed the Ravine in safety, and had reached the border of Nandi country, where they encamped for the night. The Nandi warriors had watched their every movement, and suddenly swooped down and killed every man but the one who escaped to tell us the terrible story.

Our doctor attended his wounds and he was able to go on with us and point out the scene of his awful experience. It was a ghastly and painful sight, and we delayed our march an hour or two in order to collect letters and valuables belonging to waiting friends in Uganda, and to obliterate the more marked evidences of a savage attack.

Now, however, we are hurried on along the iron road, through the countries of Nandi and Kavirondo to Kisumu, also named Port Florence, after the wife of some official, whom I sincerely hope was not responsible for choosing such a filthy, shallow, fever swamp at which to fix the Uganda Railway terminus.

The population of the Kisumu Province is 


\section{Uganda to Mount Elgon}

roughly computed to be a million and a half, and embraces the peoples of Nandi, Lumbwa, Kavirondo, Sotik, Kisi, and Ugaya.

The Nandi and Lumbwa peoples are related, and belong to the Nilotic Bari group. Both are of a fierce temperament, but the Nandi have given the Administration most trouble, and have recently been removed from the vicinity of the railway into a reserve situate to the east of Mount Elgon. This move on the part of the Government is probably neither more nor less than to restore the Nandi people to their original home from which they were driven by the Masai when that people first invaded Equatorial Africa a hundred years ago.

Kavirondo is populated by two distinct races of people-the Bantu, who are of the aboriginal stock, still found on Mount Elgon, and the Nilotics, who are closely related to the Gang or Acholi Lur people, from whom, legend declares, they separated to seek a country of their own, and having sought to encroach on the land of the Kimam people who occupy the country north of Lake Kyoga, i.e., north-west of Mount Elgon, they were thoroughly beaten and driven through the country, now uninhabited, west of Elgon, right down to the shores of Lake Victoria.

The surprise of a traveller who, fresh from 


\section{The Nilotic Kavirondo}

Europe, has never left the train on its journey from Mombasa, and now finds himself deposited in the midst of a grinning crowd of absolutely nude natives, must be great indeed. Yet that is just what he will find at Kisumu.

Nowhere are the Nilotic peoples very keen on clothing, but nowhere are they less keen than in Southern Kavirondo; and, of course, the question again crops up, What can be done with such a people? Here they are in teeming numbers, very industrious to supply their own scanty needs, rich in cattle, splendid in physique, in no danger from white competition, for, as I said at the beginning of this chapter, the western side of the Mau Escarpment is another climate to that of the Highlands of British East Africa.

Here we are in the tropics indeed, with all the discomforts, all the dangers incidental to a tropical country and climate; and whilst the white man and Asiatic is able to live and supervise for a short time the work of others, they will never be able to look upon this part of Africa with such longing eyes as to cause the native any anxiety with respect to the land.

The question is, Can we cause him any anxiety at all? Here is a vast population, touched by. the Uganda Railway and the varied influences that represents, and yet quite untouched by any 


\section{Uganda to Mount Elgon}

desire for progress in the way that the best kind of civilisation might suggest.

Nothing has been done by the Government to whet his appetite for progress; for taxation, whilst necessary, tends the other way, and no country will develop on taxation alone.

The native of British East Africa has not been utterly neglected, however, for since the year 1844, when the Church Missionary Society began work at Mombasa, the Christian missionary has been striving to improve his lot.

It was the agents of this Society that gave an impetus to the geographical enterprise that eventually led to the discovery of the great inland lakes and the source of the Nile. It was chiefly through this Society's efforts that the Parliamentary Committee of 1871 was obtained, which led to Sir Bartle Frere's Mission to Zanzibar in the following year. In 1874 Frere Town was established by the Rev. W. S. Price, and in 1875 five hundred slaves, rescued by H.M. cruisers, were handed over to him, and housed, fed, instructed, and trained to work for their living.

Since that time the work at Mombasa and Frere Town has been strengthened by additional workers, and other stations have been opened at Rabai, Giryama, Taita, Taveta, Ukamba, Nairobi, Kikuyu, and Kenya. Other sections of the 


\section{The C.M.S.}

89

Christian Church have been awakened to a sense of responsibility and opportunity with regard to this part of the world, and good work has been and is being done by the Church of Scotland Mission established at Kibwezi in 1891 under the auspices of the Directors of the British East Africa Company, and some other missions of more recent date.

All education and industrial training offered to the native up to a little over a year ago was offered by these various missions, first initiated by the C.M.S.

Since 1907 a trading company has been established in British East Africa for the purpose of developing the native products. Being under Christian auspices, the native people come in for a share of attention, but I have not yet heard with what success.

The religious side of the white man's effort to help the native has certainly advanced during the last few years, for thirteen years ago there was nothing being done between Kibwezi and the Lake.

Let us not forget, however, that the neglect by the Christian Church of the various tribes we have been looking at in this and the last chapter, until the opening up of their countries by the railway, and the introduction of good 


\section{Uganda to Mount Elgon}

and bad - often very bad - civilisation, has tended to make the work of the missionary a thousandfold more difficult than it would have been a few years ago.

The work of the C.M.S. at Mombasa and Frere Town has always been somewhat difficult, but with the great increase of trade it is doubly so now, for like all seaports the temptations offered to the natives are of a specially strong character, and we who know our Liverpool, London, Sunderland, and Tyneside will understand and sympathise with those who are tempted and those who are seeking to help them.

It is a sad fact that much of the native Christianity-if I may so express it-I mean, of course, the native conception and reflection of Christianity, has always suffered from the poor example of nominal white Christians; and this has been the more marked since the advent of the Uganda Railway.

Shall I ever forget the sight I saw at Frere Town and Rabai-which I suppose would be impossible to-day-when crowds of people who had themselves been slaves, and others who were the descendants of slaves, welcomed us to Africa as the ambassadors of Christ, joined with us in intelligent worship of the Great God and Father of us all, committed us by prayer into 


\section{Mohammedan Missionaries $9 \mathbf{I}$}

His keeping, and prayed that the Holy Spirit would go with us into the very countries from which they themselves had been dragged by slave-traders, and enable us there to preach the gospel of all True Light and Life and Liberty, Jesus Christ?

This is the time of special temptation, special need, and special opportunity. Is the Church to expect the Government to do its duty and yet neglect her own?

Let us remember that Mohammedan traders from Abyssinia are meeting Mohammedan traders from Mombasa, and every Mohammedan trader is a missionary of the false prophet. Mohammedan interpreters for some reason or another are in every Government boma, and Mohammedan interpreters are no less missionaries. These men are not afraid to push into unknown countries, whilst we Christians are in danger of sitting on each other in one or two districts quite near to the railroad. These men are never ashamed or tired of propagating their faith, whilst to the average white man to mention the name of Jesus is supposed to be "bad form."

Now seems the time and opportunity to press in to British East Africa large forces of evangelists with cool heads and warm hearts, capable of co-operating with the Government 


\section{Uganda to Mount Elgon}

to supply all necessary education without let or hindrance to their evangelistic misson. Should it ever come to a choice between evangelisation and education, for the sake of some proffered grant, then let the grant and the education go; but of this anon.

At present we are at Kisumu. We have travelled 584 miles, in as many days as it once took us months, and here we are without one man having dropped out; not a worry about food or water, wild beast or savage tribe: a marvel indeed! Let us be grateful and take off our hats to this monument of British enterprise, then turn our gaze upon another wonder for size, grandeur, and beauty-the Lake Victoria. 


\section{CHAPTER V}

\section{THE LAKE VICTORIA: ITS SURROUND- INGS AND SCOURGE}

First view of Lake Victoria-A sight to enrapture-Waiting for breakfast--A picture from fairyland-The islanders of Sese-A voyage of discovery-Life hanging by a thread -From Uganda to German territory-Baganda influence -Dangers of the sea-The Bavuma-Steamers-Area and variety of Lake-A round trip-Sleeping sickness-Death and desolation-Doctors A. R. and J. H. Cook-Sleeping sickness means great suffering-Dangerous patientsSpread of the disease-Cause of the tragedy-The tsetse fly-The crocodile theory-Is there a cure ?-Experiments -A barrage over the Ripon Falls-Nearing Uganda.

W $\mathrm{Y}$ first view of Lake Victoria was from a 1. high hill in Usoga, one morning at break of day.

Placid and glittering, kissed by the slanting rays, dotted with innumerable islands, and backed by mainland that at one point appeared to be a grassy lawn, at another a cultivated garden, at another a frowning headland, and 


\section{Uganda to Mount Elgon}

at another an inviting sylvan retreat; it was a picture to enrapture and remember for ever.

At closer range this great fresh-water sea, nearly 4,000 feet above the Indian Ocean, was no less charming, and infinitely more interesting, with quaint inhabitants on its shores and in its waters.

There, within a stone's throw, for all the world like a $\log$ of wood, lies a great lazy crocodile, waiting for the breakfast it is all too certain to get, for the cattle will soon come down to drink, and the younger ones are careless. Or, maybe, it has heard the rhythmic splash of paddles keeping time to the spirited chanting, albeit in a minor key, of some delightful folk-song being sung in the distance. It seems to know that we are waiting for the singers, and listlessly follows our example until around a jutting promontory comes into view a picture that might have dropped from fairyland, at which the crocodile immediately vanishes out of sight.

A flotilla of canoes such as we have never seen before, long and graceful, coloured red with earth, and prows adorned with the horns of antelope. Each vessel is propelled by twenty paddlers or more, who, the moment they catch sight of us, put additional zest 


\section{Sailor-men of Lake Victoria 95}

into both song and work, and send their fraillooking craft skimming towards us.

They are the islanders of Sese, a populous group, situate to the north-west of the Lake; and they are also the subservient sailor-men of Uganda, who have been sent with part of that kingdom's navy to carry us a six days' voyage from the shore of Kavirondo on the east, to Uganda in the north.

They run their canoes into shallow water and jump overboard heedless of danger, until there is a shriek and a tremendous noise of splashing and shouting, to the consternation of the European onlookers, who are certain that some tragedy has happened, until they learn later that only a portion of a man's clothing had been secured by the crocodile. The man was badly scared and the rest were more careful.

All loads are quickly put aboard ; the Europeans given places of honour under a thatched canopy temporarily erected in the bow, and the voyage begins-a voyage of discovery.

The traveller is naturally interested in the vessel that carries him, and he is considerably disconcerted to learn in the first place that it literally hangs together by a mere thread. He learns also that these dusky mariners are very human, and immensely enjoy the knowledge 


\section{Uganda to Mount Elgon}

that to suddenly stop paddling and punctuate their song by a mighty thud with the paddles on the side of the canoe, which makes it shiver again, increases the white man's nervousness about himself, and his respect for their bravery. These preliminaries, however, are soon over, and the European enough at ease with men and boat and sea to enable him to secure such information as the following :-

It takes fourteen days to travel by canoe from Uganda in the north to German territory in the south.

The Basese, from whom the canoe men are drawn, are the people who inhabit the group of islands already mentioned. They were conquered by the people of Uganda and made tributary to them.

Baganda chiefs look upon the islands as their property, and one, with the rank and office of admiral, is lord over all. He is responsible for organising the islanders and their canoes into a navy, to be used by the Baganda on their many marauding expeditions.

The Basese build the canoes and are allowed to cut timber for this purpose in the forests of Uganda. There I have often seen them, hewing with their insignificant axes giant trees from each of which they secured only two boards ; all the rest was waste. The boards were 


\section{Boats and Billows}

thinned and bent and sewn together with the fibre of a palm-tree, which lasts a considerable time, but has been known to give way and allow the keel board to drop out at an inconvenient distance from the shore.

Even with such a liability to dissolution, the canoe on the Victoria Nyanza is an advance on the primitive dug-out, still generally used on Lakes Kyoga, Albert, and Albert Edward.

Nothing will induce our paddlers to face the open sea; they know its moods too well-its sudden squalls, its terrible storms that lash its ripples into mountainous billows that would at once engulf their cockle-shells. They make for shore at the first sign of "weather"; and, of course, the traveller must encamp on land at night. Here he makes the acquaintance of Africa's scourge, the mosquito; and more likely than not he will receive a nocturnal visit from the hippopotamus which in the daytime is too shy to seek exercise and sweet potatoes.

Only a passing glimpse of Usoga's luxuriant shores is possible, but it is necessary to visit en route the group of islands known as the Buvuma Islands, lying to the north-east of the Lake. 


\section{Uganda to Mount Elgon}

Less than ten years ago this group, like that of Sese, was thickly populated; but whilst the Basese had become subservient to Baganda, the Bavuma, being a hardy, warlike, and independent folk, had held their own against the repeated attacks of the people from the mainland, and not until the Baganda were assisted by Stanley and Williams were these islanders the least subdued. To travellers they were kind, peaceable, and hospitable.

Other islands were met with, lying off the shore of Kyagwe, Uganda's south-eastern province, and a great deal might be written about the flora and fauna of some of these beauty spots; but, alas! one absorbing interest overshadows all others, for the islands and mainland is in the grip of a terrible scourge-the sleeping sickness-a sorrowful reason for the passing away of the old sights and sounds that made Lake Victoria a scene of never-failing interest. Another, and happier, reason why the old method of traversing the Lake has passed away is that more up-to-date craft are to be found; and the traveller by the Uganda Railway has but to step from his carriage on to a handsomely found Government steamer-one of four now plying for freight and passengers between the railway terminus and the countries bordering the Nyanza. By one steamer, which leaves 


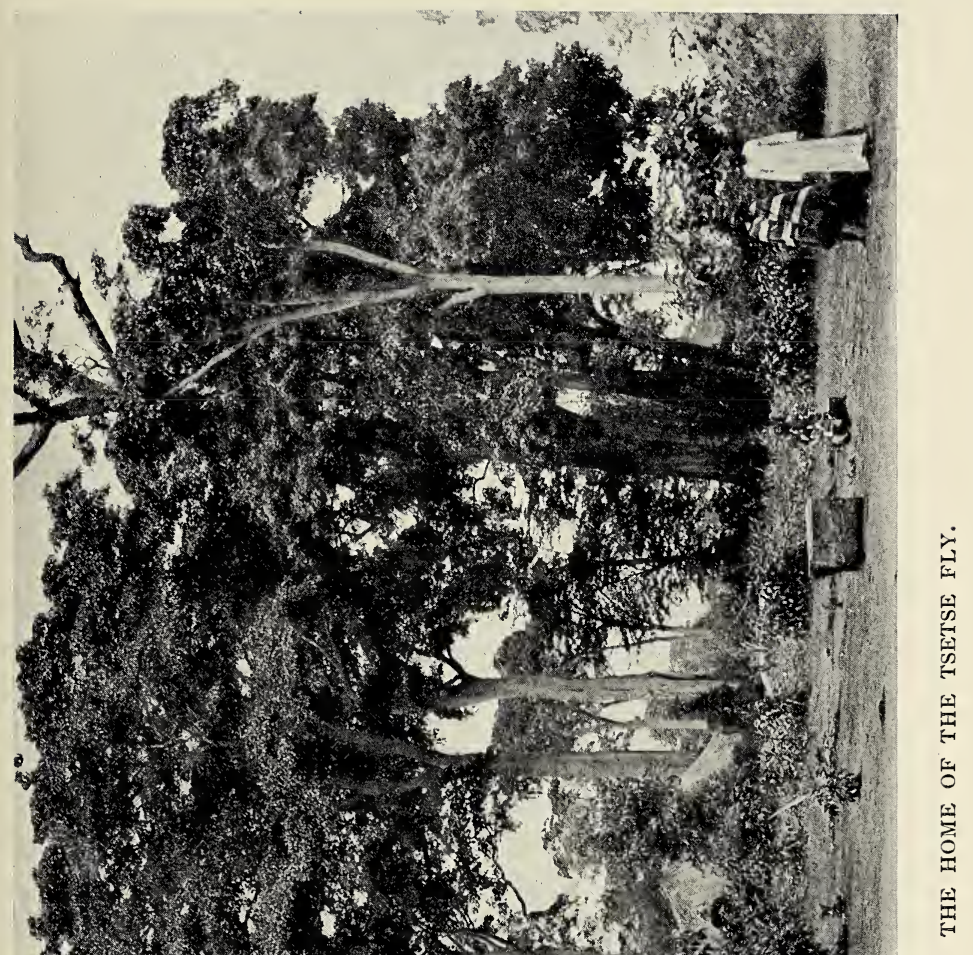

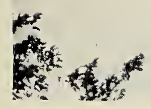

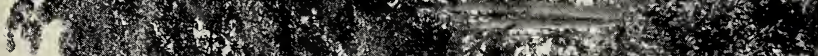
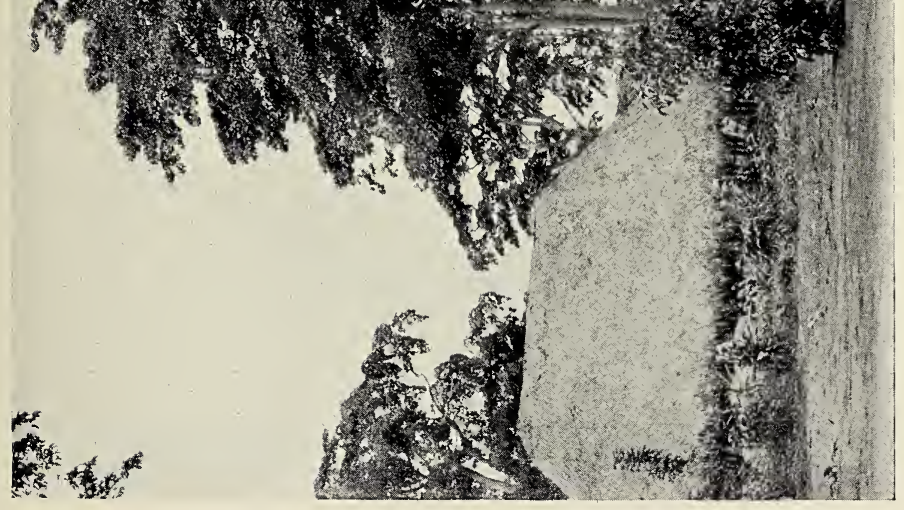



\section{A Round Trip IOI}

Kisumu every fortnight, he may, if he wishes, make a tour of a thousand miles. It will take him south to Mwanza in German territory, then west to Bukoba, north to Entebbe, east to Jinja near the Ripon Falls, and thence to Kisumu again.

Such a tour will give a good idea of the Lake's vast area of 40,000 square miles ; the variety in scenery and vegetation; whilst the fish, crocodiles, and hippopotami will always keep interest alive.

By another steamer, which awaits the weekly "up" train, it is possible to cross direct to Uganda; and this is now the natural route for all who wish to get into speedy touch with the official, business, or missionary life of that country; but let us linger by the way, and see for ourselves some results of this awful disease of sleeping sickness, unknown to Uganda or East Africa ten years ago.

It meets us at rail-head, and if we travel southward we find that it has been before us. It has decimated the population, and is spreading still further south, in spite of every precaution of English and German specialists. Northward its ravages have been even more appalling, because of the greater population it had to work amongst; and as we march through Kavirondo and Usoga to the Ripon Falls where 


\section{IO2 Uganda to Mount Elgon}

we may take the ferry to Uganda, we pass through silent wastes which, less than ten years ago, were teeming with population. The same scenes of desolation and death are to be met with all round the Uganda shores of the Lake, and on all the islands.

The men who made and paddled the canoes have been almost totally wiped out of existence, for not an island has escaped. Death, death, death everywhere; and death preceded by heartrending suffering.

Writing of one of the Buvuma Islands, situate near to Usoga, the "Uganda Notes" says : "Bugaya is best known as a port of call for the steamers, where firewood is taken on board. At one time the island had a dense population; a few years ago the chief, Muzito, was capable of putting 2,300 fighting-men in the field; and the people were so crowded that each man had his plot of ground marked out for him-a long strip, some three or four yards in width and perhaps half a mile or more in length. These plots were marked off by stones laid in a line, and no one was allowed to dig in another's plot. The stones still remain, a melancholy mark of past prosperity, but the gardens are, for the most part, indistinguishable from a field. The whole island has a deserted appearance. Where, a few years ago, there were 1,900 houses occu- 


\section{Sleeping Sickness}

pied, there are now hardly 200. In one shamba (garden village) there stood 200 native huts; now only 6 of these are tenanted. In another of 170 huts, only 2 remain; in a third of 250 houses there is left a solitary one. In another shamba, high up on a hill, of 70 huts, there is now not a single one occupied. Nor is it that the people have left: they seem to prefer to die in their homes; and very few, if any, have left the island."

The same story is true along the coast of the mainland. Villages $I$ once knew well have passed out of existence, and, where houses remain, the people are dead. In one instance where the huts were standing I approached those having evidences of occupation; indeed, the owner of one sat at the door, and I wished to ask him the distance to the Lake. He sat as a native does in sickness or sorrow-with his arms resting on his knees, and his head bowed down. I gave him the customary salutation and rested my hand upon him, when my boys, in sudden terror, besought me to leave the place. I asked them why, and candidly confess I was somewhat startled when they informed me that the man from whom I was seeking information was a corpse. Alone and untended, he had passed away just before my arrival-the last of his village probably to succumb to the awful 


\section{IO4 Uganda to Mount Elgon}

affliction from which they all think it useless to flee.

I think I am right in saying that sleeping sickness was first observed in Uganda by the Doctors A. R. and J. H. Cook, of the C.M.S. Hospital at Namirembe, in the year 1901; and from that time these two exceptionally clever and self-denying men have been untiring in their efforts to find a cure and to alleviate the sufferings of their patients.

To many the fact that the patients suffer is a great surprise, because, misled by the namesleeping sickness-they suppose the people are simply attacked by drowsiness and quietly sleep away.

How very different is what actually happens! Lassitude, drowsiness, swollen glands, severe pains in head and chest; emaciation comparable to phthisis condition ; restlessness, pain in stomach and abdomen; hallucinations; inability to control one's actions, so that the patient is liable to become a mental, moral, and physical wreck-a terror to himself and the neighbourhood in which he resides.

In some cases the development of the disease is very rapid, whilst others linger for years after having been declared affected.

It will be easily understood with what anxiety such a plague has been studied by the authori- 


\section{A Terrible Disease $\quad 105$}

ties, and how all concerned have longed for a cure. Everything possible has been done by the Government doctors-noble young fellows who have risked their lives-and, in one instance, Lieut. Tullock gave his life in seeking to trace the course of the disease.

However the disease came to Lake Victoria, all are agreed that it came from the west. It is also generally agreed that the enmity of the various tribes made it impossible for people to pass from one district to another until the European nations apportioned Africa, when the Pax Britannica made it possible for travellers to come in from the west and bring with them, first the jigger pest-which in 1897 had not reached Mombasa, but to-day is busy in Indiaand then the sleeping sickness disease which has done such havoc, as we have seen, and is now making its way to Lake Tanganyika and the life of British Central Africa.

What causes the tragedy? is the general question, and one not very easy to answer; for the presence in the cerebro-spinal fluid, or in the blood of a patient, of a minute worm-like object - a trypanosome or trypanosoma discovered by Dr. Castellani-which sets up a condition akin to cerebro-spinal fever or meningitis, is really no answer to the idea behind the question, "What is the cause?" 


\section{06 Uganda to Mount Elgon}

It has been conclusively demonstrated by Colonel Bruce and his assistants that the connecting link between the trypanosome in the patient and the source of the disease is a kind of tsetse fly-the Glossina palpalis - about which there can be no mistake, for although no bigger than the ordinary house-fly, it can be picked out at once because of the peculiar way in which it crosses its wings when at rest.

The habits of these flies have been carefully observed by the doctors at great personal risk and inconvenience. It has been found that they live in the trees at the side of a lake or on the banks of a river, and that they lay their eggs on the ground near to the water's edge. It has been proved that, like bees, they "home" to a certain district, and it is hoped that by killing off the eggs, cutting down trees, and generally making a district less favourable to propagation the pest may be cleared out.

Still the question remains, "What is the source of the disease?" The fly carries the germ, the trypanosome is the evidence of the germ having been propagated, but whence comes the germ apart from already infected patients, and, consequently, what is the real cause of the disease?

In the year 1905 I heard that crocodiles had been suggested by some English doctor, and my 


\section{The Crocodile Theory 107}

informant was equally certain that hippopotami were to be taken into account; consequently I was much interested to read that Professor Koch, the German specialist, in his account of the subject before the German Emperor, professed his acceptance of the crocodile theory, i.e., that the fly feeds on the blood of the crocodile and carries from the crocodile to the human being the germ of sleeping sickness, and that the first thing to do is to exterminate the crocodile.

Whether this theory is correct or not, it seems somewhat strange that no effort has been made to exterminate such a pest and menace to human life as the crocodile. For the theory itself we must remember that crocodile, tsetse fly, and native were living close together before the year 1900-then why was there no sleeping sickness? The germ of that disease was probably lacking, and was brought when trade routes and inter-tribal communications were opened by the Pax Britannica. If so, how did it get to the islands first?

Such questions are of far less importance than the next one, namely, How can we destroy the trypanosomes in the patient? English Government doctors, civil and military, doctors from the Liverpool School of Tropical Medicine, the 


\section{ro8 Uganda to Mount Elgon}

medical missionaries Cook, German and Belgian doctors have all been labouring with patience, zeal, and wonderful self-abnegation in their endeavour to answer this question, and with a certain amount of success, but, alas! without securing a permanent cure. To be inoculated by the fly-Glossina palpalis-is to receive sentence of death.

Small doses of arsenic hypodermically injected was one of the first experiments, but it caused the patients a good deal of agony, some of them begging to be allowed to die. An atoxyl, an admixture of arsenic and aniline, was used at Liverpool and London, and then tried in Uganda. This treatment has not only given relief, but has caused the trypanosomes to disappear, for a time, from the blood. Whether, as has been suggested, their reappearance can be prevented and a permanent cure effected by a further administration of a salt of mercury remains to be proved. After long delay the Government decided to deal with the affected areas. Segregation camps have been established and the people removed from the Lake shore. All living in camps are placed under the atoxyl treatment, and the percentage of deaths has been low.

Unfortunately a serious famine has interfered with the good work in Usoga, and 


\section{The Tsetse Fly}

IO9

thousands of deaths have taken place that may or may not have been connected with sleeping sickness.

All shrubs and trees are being cut down near to the Lake side, and large tracts are being put under sweet potato cultivation. In this way the fly is deprived of its home, and will, it is hoped, die out. The eggs of the fly can only be effectively dealt with by raising the level of the Lake, and although we have not yet reached the Nile, I may, apropos of this subject of sleeping sickness, express the wish that soon we shall see a barrage built across the Ripon Falls, and thus be able to regulate the height of the Lake in such a way as to deal with a pest like the "Kivu" fly by drowning out its young.

Now let us continue our journey across the Lake in what is more like a trim, well-kept private yacht than a trade steamer. Everything on board is spick and span; and the dusky sailor-men move about in an alert fashion that speaks well for the kindness and ability of their officers. On deck and below, all is in such order that the voyage from railhead to Uganda is far too short. A wellcooked meal, a clean bunk, and a comfortable bath is a great luxury compared with old methods of crossing; and the wonder and ex- 


\section{IO Uganda to Mount Elgon}

pectation of the traveller are heightened when he learns that the brisk youth who oils the engine in such a business-like fashion is only an ordinary peasant lad of Uganda, the shores of which he is fast approaching. 



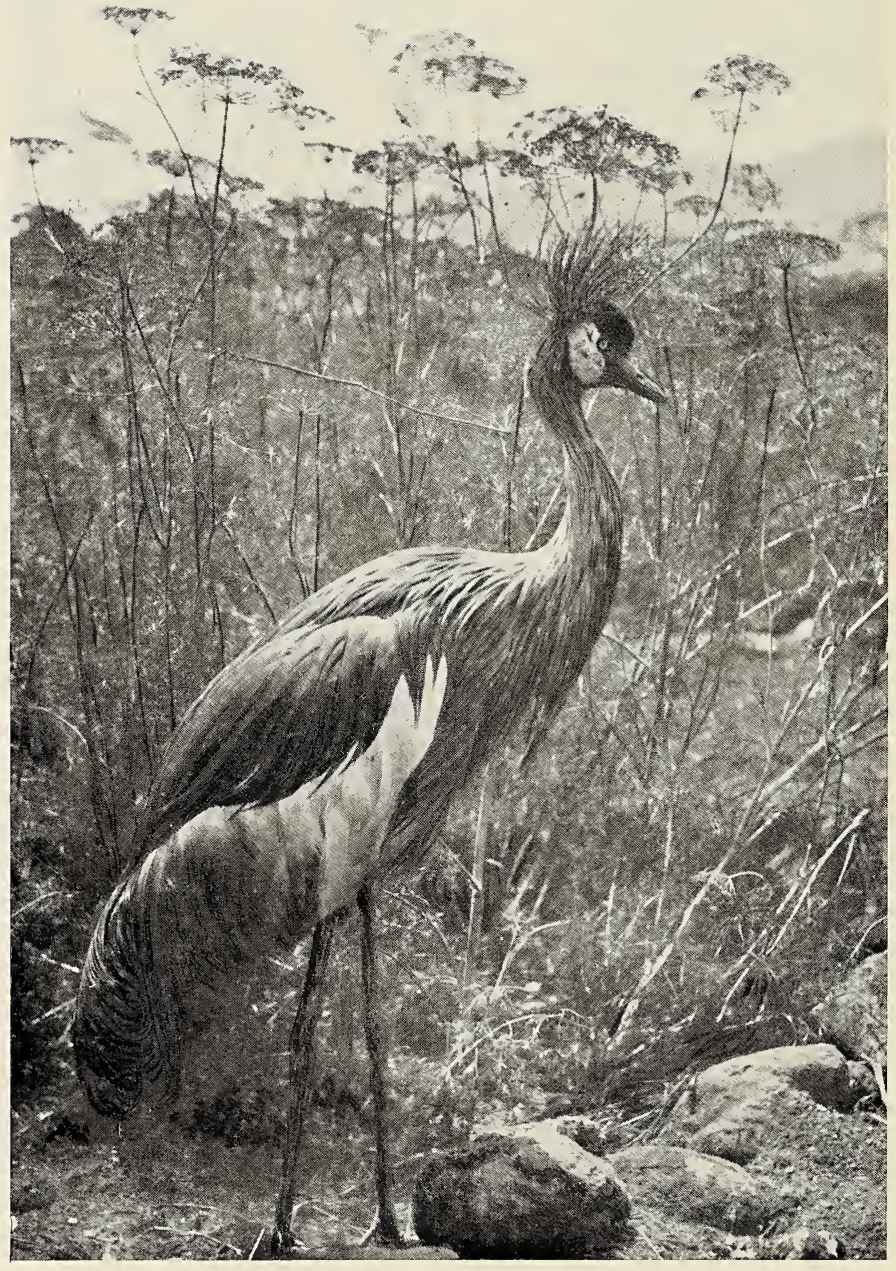

A GOLDEN-CRESTED CRANE. 


\section{CHAPTER VI}

\section{UGANDA： FLORA, FAUNA, AND OTHER THINGS}

Beautiful Entebbe-Capital of civil administration-The native opinion-A mistake-The road to Mengo-No advance-Appearance of country-A large garden-Cotton cultivation-Value of cotton export-Climatic conditions -Extent of Uganda Protectorate-Agricultural possibilities -Rubber, cultivated and indigenous-A cheap concession -Timber-Wild animals-A bull buffalo-Death of Dr. Densham-A native report of a lion hunt-Insect pestsMosquitoes and malaria-Value and use of mosquito nets -Danger of rest-houses-Necessity of change-Protection against sun-Blackwater fever.

$\mathrm{B}_{\text {EAUTIFUL, perfectly beautiful! is the }}$ verdict of whoever views Entebbe, Uganda's port, from the deck of the steamer. And, if possible, more perfectly beautiful when viewed from certain vantage-points on shore.

Well-built brick bungalows, substantial offices, up-to-date stores, a botanical garden, a bank, a pretty English church, good roads, (in dry 


\section{I4 Uganda to Mount Elgon}

weather), and a Government House, all bespeak the capital, and such it is, for here is the seat of Uganda's civil administration, very beautifully but very mistakenly situate at the end of a narrow promontory from which the untutored native says the white man is ever ready to flee in time of danger.

No doubt the idea of safety was in the military mind that chose the situation; but at this time of day there seems little to recommend it save the fact that the steamer from Kisumu calls once a week. It is not the real capital of Uganda: it is not at all central either for trade or administration; it has cost much to make it tolerably healthy, and it will cost more to keep it so.

The whole promontory, with the exception of the township, which has been cleared of trees and scrub, is infested with the sleepingsickness fly, and we must travel further inland to gather any true idea of Uganda country.

A broad, well-cultivated road has been made from Entebbe to the native capital of Mengo; and the journey of twenty miles may be done in ricksha, bullock wagon (if you have a day or two to spare), or on foot. At no distant date it will be done by motor-car; but even bullock wagons are in advance of this and other roads, which are only kept clean by repeated cultiva- 


\section{The Civil Capital}

tion. This means that one length may have a beautifully smooth surface and the next be like a ploughed field.

Streams and swamps are crossed by the most primitive bridges which last but a very short time, and soon become greater hindrances than helps to traffic; and it is no uncommon sight to see stranded wagons, or the traction engine of an enterprising firm, waiting for help to be delivered from the slough that makes the most optimistic business man inclined to despond.

This condition of things is general throughout the Protectorate, and with the exception of an effort to utilise the present native-made roads for the purpose of growing rubber-trees along each side, and to build culverts on the road leading north, no advance has been made on the native idea of providing for pedestrian and vehicular traffic. A month's neglect is sufficient to make one of the present roads invisible, in a little longer it is impassable; and not much more time would be necessary to blot out every trace of an occupation that counts its success by a development of taxation.

Let us not quarrel, however, with the only kind of road at our disposal, but use it to see what can be seen.

Long grass, with an emphasis on the long, banana groves, hill and dale, are the pre- 


\section{6 Uganda to Mount Elgon}

dominant features of the district through which we are passing; and these features are common to the whole kingdom of Uganda.

The hills have the appearance of having been sat on before they reached their proper height; and the valleys are as a rule noisome swamps.

Travellers marvel at the wonderful fertility of the country and at the extent under cultivation. It almost appears to be one huge garden chiefly growing bananas and plantains. This is as it should be, since plantains are the staple food of the people; but here and there are evidences that the land is able to produce more than plantains, and may indeed have a future interesting and important to the working men of England.

Huge tracts are under cotton cultivation, to which the natives have taken most kindly. They easily understand its requirements, and it gives a quick return. It has been found that even without European supervision the Muganda is able to prepare the land, sow the seed, and bring a raw material to market, which will compare for length of staple and general quality with any in the world.

So keen was and is the desire to grow cotton that for a time there seemed as if there might be a glut upon the market, owing to the lack 


\section{Cotton Exports}

of ginning machinery; but this difficulty has been quite overcome by the enterprise of two trading companies which have recently erected machinery in the native capital to enable them to deal with any quantity.

In 1904 the cotton export was valued at a few hundreds of pounds. Last year its value was at least $£ 50,000$.

The soil, rainfall, and general climatic conditions of nearly the whole of Uganda Protectorate-which stretches from Mount Elgon in the east to the Mountains of the Moon in the west, and from Gondokoro on the Nile in the north, to the German East African frontier on Lake Victoria-seem to specially fit it to become one of the best cotton-producing countries in the world. It is not necessary to labour the advantage such a thing will be to Lancashire.

The castor-oil plant is in evidence everywhere, as is also the tobacco plant, but neither of them have yet been taken in hand by experts with a view to development and exportation. The same may be said of coffee, which can be seen growing in the various banana gardens, and growing so well that berries from an untended plant were declared very fair quality on the London market.

Ground nuts and chillies are grown in great 


\section{8 Uganda to Mount Elgon}

quantities, but chiefly in the east and north-east parts of the Protectorate.

The country is rich in fibres, but probably for lack of patience there is no cultivation or preparation of these, for which from $£ 30$ to $£ 100$ per ton might be procured in London.

On every plantain grove there may be seen the tree from which the natives strip the bark which, when beaten with their hard-wood grooved mallets, dried in the sun, and sewn together, is used as the clothing of the people.

Here and there we get a glimpse of garden stuff that reminds us of the homeland, and cannot but marvel at a soil and climate that does so well for cabbage or cactus, tobacco, or tomato.

We have already seen the rubber-trees planted at the roadside, but there are also trees and vines indigenous to the country; and one syndicate, the Mabira Forest Company, has secured the right to deal with a large tract of land in the Province of Kyagwe, on which they estimate there are 2,000,000 Funtumia elastica trees from which they expect at once an annual return of $£ 137,000$.

I understand that this concession was made in the first place for a few hundred pounds.

Other companies have been formed for the purpose of working rubber plantations, and 


\section{Dangerous Animals}

one or two private settlers are at work putting in trees; but they will have to wait from five to ten years, according to the kind of tree, before they can expect a yield of latex.

Uganda is not very rich in timber, but there are three or four very good kinds available for all general local needs, and our journey takes us through the exquisite little forests from which these are procured.

Here probably for the first time we come across the wild animal life of Uganda: perhaps only an impertinent little rascal of a monkey with his short grey coat, brown tail, and lively chatter, but not unlikely a leopard, lion, or buffalo may be met with, in spite of the large amount of cultivation and population.

On my last journey to Mengo, the native capital, a solitary bull buffalo dashed across my path, quite near to a native village. He had been driven out from the herd, and was consequently a very dangerous character-an animal to beware of, yet much sought after by sportsmen. It was just such an animal that killed an able and promising official of the Administration, Dr. Densham, whom I knew well in Usoga, and whose brother is well known in the town where I am now writing this.

It seems almost incredible that the king of beasts should also lurk about the capital, but 


\section{20 Uganda to Mount Elgon}

within the last few months two lions were killed without a day's march, and I append the story of the hunt given in Uganda Notes by Ham Mukasa, who wrote that quaint book, "With Uganda's Katikiro in England."

"We were told that the lions had roared the last night from Kasai in Bukerere, Kajungujwe's place. At first we did not believe that, but the next morning the people who came from Bukoba told us that they had seen their footmarks on the road at Kasai. But on August 1st they (the lions) walked hard a good journey, and reached Mukono and went by the road which goes from behind my fence and leads to the market. They reached the place where my cows live, about 260 yards from my fence. Then they found the cows in the house by themselves; the herdsmen were not there, they were waiting for food in the fence so that they might go back to the cows.

"At half-past eleven my big dog Blanco barked loudly, so I understood that it was the lions. We were at table, $\mathrm{H}$. Luganda and I, and I told him that my dog was raising alarm for the lions, for they had come, and I heard a voice like that of a door which is knocked; but when the herdsmen were going back they met the lions in the middle of the road eating the cow which they had killed, and they roared very loudly to 


\section{A Lion Hunt}

make the herdsman run, but he did not run, for he had a little boy with him, and the lions were two. Then that herdsman for his bravery did not run, he lifted his arm, the lions ran away from the cow and he raised the alarm and we all heard him.

"Then all my boys went at a great rate and found the cowman standing where the cow was which was killed. The lions had eaten all the chest and entrails and lungs, the stomach only was left. Then the boys went into the house in which the cows live to see whether they were all killed. They found one cow hiding at the end of the house with her calf, and they brought her from the house and they could not see the others and we thought they had gone mad and we would see them the next day, so we stopped (searching).

"But when I came out of the house I went there with my gun and two boys and I stood where the cow was which was killed while the boys were looking for the others. Then $\mathrm{H}$. Luganda saw me and said, 'Sir, do not stand on the cow that is lying in the road.' In that time the lions were with me, one on my right and the other on my left, lying on the sides of the road in the jungle. One of them was lying eight yards from where I was and the other ten yards. They were quiet and did not breathe hard, but 


\section{22 Uganda to Mount Elgon}

my big dog heard them and started twice and looked either side. It was very dark and it was going to rain. Then $I$ beat my two drums in the way of war drum beat. All the people who live near came and I took them to see that they (the lions) had killed the cow, and we found them eating again. When they (the lions) saw us they ran away, and we left the cow which they had killed in order that they might eat a good deal and not go far away so that we might hunt them the next morning. Then $I$ told all the people that when they would hear the drum the next morning they should be ready for hunting.

"When the morning broke the drums were beaten and all the people did what I told them; they came before me and said they would do their best to kill the lions. I sent to the doctor at Kyetume to ask him whether he would go for hunting. Then he sent Mukusu, and gave him a large Masai spear. Then Mukusu brought people from the Camp at Kyetume, about a hundred men or more, and they saw the lions in the little wood which is near my place. Then I stayed in the market-place and Mr. Baskerville found me there when he came to congratulate me about what had happened last night; and he was sorry he could not go with us to hunt for he had work to do in the church, for it 


\section{Quaint Native Description I 23}

was Sunday. So he remained to take prayers with the women and children, on that day all the teachers were hunters. Y. Kaizi and H. Luganda were with the hunters, and the Sunday service was held by Mr. Baskerville, and it was he who prayed for us on that day.

"Now when I was sitting in the market-place many people came with their hunting nets, then I appointed Mukusu to dress (distribute?) the people so that I might go after him. While I was there Captain Gray came with two guns. Then we looked for them (the lions) very much and we could not see them, and Dr. Gray was tired and went home at 1 o'clock in the afternoon, for there were many pigs in the forest and we could not tell the lions' footmarks from the pigs'.

"When I saw that the people were very tired and every one thought in his own way and were disputing with one another that the lions had passed (but they were left behind us where we thought that they were not) then I sent S. Mulowoza to examine well, and when he came back he told me that they were behind in the little wood. Then I told all the people to go home for the darkness was drawing near, at half-past five, and I told them that if we could not kill them (the lions), the next morning we would take out food with us and go 


\section{24 Uganda to Mount Elgon}

after the lions to Unga, where they came from. And they all agreed to that and went home.

"At ten o'clock in the night the lions came out of their hiding-place and went to the cow-house where they had killed the cow and peeped into it, but it was empty, and they went down and passed by my station at Nasuti. When they reached the little wood which is in front of the station they went in there and stayed there till half-past three when they went up in the circle road which leads to Kauga and reached the porters' compound, they passed quite near the porch, four yards from the house to the place where they passed. And they went down into the forest Lyajah and across the river to Kirowoza and they reached the place known as 'Balimumperamukyalo' in the Sekibobo's garden where there is a little wood in which they made their den. There were many little animals, about ten; perhaps they were going to eat them.

"I sent my men who are very clever in tracking animals, and I appointed my headmen whose name is N. Siga and they tracked them and saw closely the place where they had left some of their fur. Then one of my men whose name is I. Kisajaki came back and told us all that they had seen. I was at Kauga, my old embuga, and I told every chief with his people to promise 


\section{Daring Native Hunters 125}

before me whether they had determined to kill the lions. After their promises I asked them to discuss how we should hunt the lions, for they had run away from us the previous day because of their cunning. Then every one said what he thought was right, while I was silent to see if they were all right. When they had spoken I picked out what were right and I drew them a map and I prepared the people in lines so that they might fight well against the lions. Then I stopped every one to advise me and they did what I told them. Then I appointed Namutwe to line them up. But the chiefs had few people, a lot of them came afterwards and found us hunting.

"When we reached the place where the lions were I prepared the people in their places, and during that time Dr. Rendle of Kampala arrived. Then afterwards we planned to cut off a part of the place where the lions were, and I sent Siga and four beaters with him and they went and cut off the part of the place where the lions were. But when they had walked eighty yards they found the lions sitting under a tree, and they both roared and the men attacked them, and the lions left them, one went on the right, and the other went on the left. Then the fighting began, the elder lion came direct at us without turning back, and we all aimed at him. 


\section{26 Uganda to Mount Elgon}

When he saw us he seemed as if he was told not to come to us, then he went half right and fell into the net. My man Kapere speared him in the chest and the spear went in one foot and one inch. When he rose up Sabagabo fired at him and Kopolo ran after him. When he turned to fight then he fired at him in the shoulder and he fell dead. He was wounded with forty-six wounds and he was killed at a quarter to three.

"This made us braver and happier, this was killed about twenty-five yards from the place where I was. I was afraid before, then I took heart.

"The other lion went up to Mukito's side and they shouted loudly when he tried to fall on to the net, and they stopped him and then he returned to us. He was afraid to come near us and he ran about twice before us like a dog. In that time you could not think that the lion was as big as a heifer. When I was going to aim at him while he was standing in one place thinking what he was going to do, the men who were with me objected saying that if I left my place the lion would pass there, only I should choose another instead of me. Then I chose Yoeri for he knows very well how to shoot, and he was made Corporal when he was with the Police. He went with Mulondo 


\section{A Good Shot}

to shoot the lion where he was and he could not see it at first because of the shrubs, but when he examined well he aimed at him and shot him in the chest and the shot went through the skin on the other side. And he fell there and when he got up for his great strength he roared in a low tone like a leopard. And soon he rose and came in a great rage and fell into the net and fell on a man named Kijoje and bit his hand, but he did not hurt him badly for he was no longer strong because of the wound. When the lion was running Namutwe shot him and he fell and was speared with eighty-four spears by the people. He was killed at three o'clock in the afternoon and fell on my left hand about thirty-five yards from the place where I was. And they told us that there was a third lion, and we went back to the place where the lions were, but there was no other, they had heard the thunder!

"We also killed nine small animals and a big snake in one place.

"Ham Mukasa, Sekibobo."

Not a bad article surely from a native pen !

The traveller need not anticipate much danger or inconvenience from wild animals, for as a rule they seem quite as anxious to get away from a human being as he does to keep clear of 


\section{28 Uganda to Mount Elgon}

them. His real danger is from the multitudinous insect pests that infest the countries west of the Mau Escarpment and make them utterly impossible for white colonisation.

Chief among the pests is the mosquito, which is responsible for more sickness and deaths than anything else. Far too long, for lack of scientific knowledge, it has been accepted and treated as nothing more than an inconvenience, but now men are well aware that the species of mosquito known as the Culex anopheles is the medium by which the minute animalcule named Malaria is transmitted from the blood of one person to another.

There is no need to expatiate on the symptoms of malaria-the less travellers know about it experimentally, the better; and the only way to keep clear of it is to keep clear of mosquitoes. Do not sit out on an unprotected verandah after sundown, and do not sleep without a net.

Of course I mean that the net should be let down each evening; it should have a small mesh, and it should not be torn. Such advice is not superfluous; for I well remember sharing the room of a friend, and in the dead of night being nearly frightened to death by a series of terrible howls close to my ear. I was confident that a leopard had got in and collared my friend, until I heard him calmly assure me that it was 


\section{Use and Misuse of Mosquito Nets I 29}

only his dog had put its head through a hole in the mosquito net, and could not withdraw it.

That was evidently the chronic condition of that mosquito net, for on another occasion I heard him recounting to a new-comer an experience he had with a large bat. It wakened him, and when he sat up it was hanging to the inside of his net. His disgust seemed unbounded when the new-comer suggested that the mesh of the net must be rather a large one.

Another real danger meets the traveller as he passes through Uganda, and meets him where he least expects it, viz,, in the sheds that have been most thoughtfully erected in the various wayside camps as shelters from the sun's rays in the heat of the day. These rest-houses were undoubtedly a great boon to the traveller; it was perfect luxury to find the shelters ready in storm or heat; and they became so popular that some Europeans ceased even to carry a tent, and used the rest-house by night as well as during the day, until it was proved that the common occurrence of Spirillum, or relapsing fever, amongst Europeans-a fever seldom fatal but exceedingly trying because of its frequent recurrence and high temperature-was due to the bite of a tick which was found to infest these shelters. 


\section{I30 Uganda to Mount Elgon}

These same camps are overrun by another scourge-the jigger; that nasty little insect which burrows under the toe-nail, forms a sac, lays its eggs, and causes a good deal of pain and inconvenience to the individual.

Like sleeping sickness, this pest has travelled from West Africa; but let us hope that sleeping sickness will not make such rapid progress on its journey. Thirteen years ago the jigger was six hundred miles from the East Coast of Africa; to-day it is working havoc in India.

Ants-myriads of them meet one at every turn : white ants, black ants, red ants. Rats, big and little; mice of various sorts; flies that seem to be made in all sorts and sizes; bees, wasps, and hornets innumerable, and all warranted to sting without provocation; spiders, that strike terror to your very soul, seek close acquaintance; whilst lice are larger in Uganda than perhaps anywhere else; and the fleas are renowned for their ability to jump and power to make their presence known.

Snakes are uncomfortably common; we have seen them drop from the ceiling and peer from the walls of our mud house, yet I have never known a European attacked by one.

The croaking of frogs, and the "cheep, cheep" of countless beetles and other insects give warning of the closing day when bats and owls and 


\section{Dangers of the Tropics I 3 I}

wheel birds come forth to assist the mosquitoes keep the night-watches.

To many, the insect life is more trying than the climate ; and both together make it imperative for the white man to seek a change after very few years' service.

The atmosphere may seem all that is desirable, but imperceptibly one loses energy, becomes " nervy," and susceptible to any disease going. It is well, therefore, to take plenty of exercise, keep the head, eyes, and body well protected from the sun, understand, as far as possible, tropical diseases, causes and cures, and so keep clear of insect life which may be responsible for some other diseases not yet understood.

One such disease is that known as Hæmoglobinuric, or blackwater, fever, which has recently been rather common with a high percentage of fatal results among Europeans.

The real cause of this fever is not known; but it has been suggested that frequent attacks of malarial fever predispose the patient to blackwater fever. Another suggestion is that the constant use of quinine is responsible for the breaking down of certain blood-vessels in the kidneys.

Against these are the statements of reliable men who declare that they have never had malaria but have had attacks of blackwater; 


\section{32 Uganda to Mount Elgon}

and for the second suggestion, that only by the constant hypodermic injections of large doses of quinine was the temperature lowered and the blackwater stopped.

Although no positive cure has been declared, it is interesting to note that out of thirteen cases, Dr. A. R. Cook, of the C.M.S. Hospital, Uganda, lost only one, and that one hopeless from the beginning because of complications. His brother, Dr. J. H. Cook, has been equally successful, and their medicine and method of treatment have been supplied to every mission station, Anglican and Roman Catholic, throughout the Protectorate. 



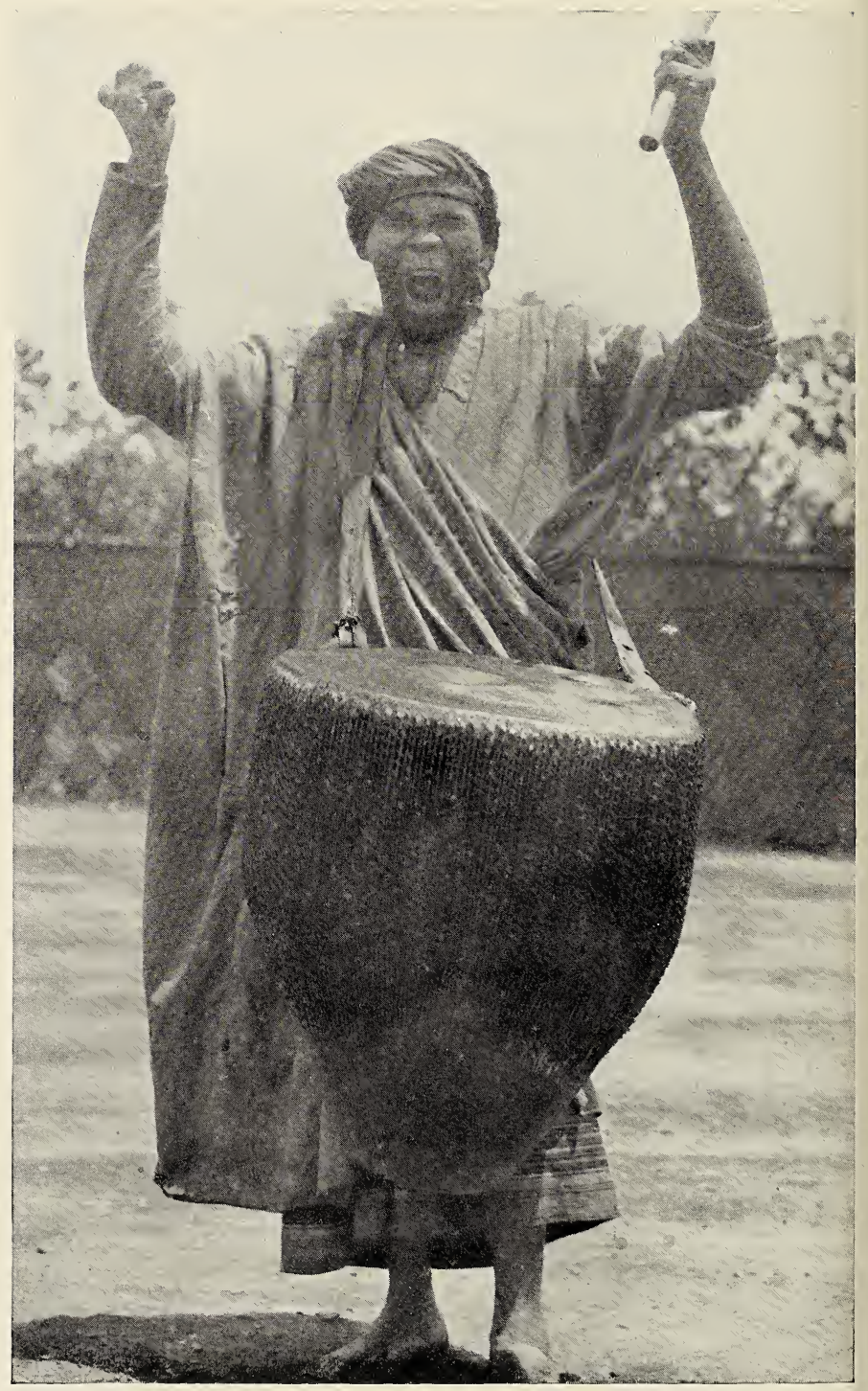

THE KING OF UGANDA'S OFFICIAL DRUMMER. 


\section{CHAPTER VII}

\section{UGANDA : ITS PAST CONDITION}

The amazement of travellers-Stanley's expectations-Concentrated cruelty-Mtesa's smiling welcome--The people of Uganda-System of government-Social life-The Bahuma-Native wine-The other side of the pictureMtesa, the causer of tears-Mwanga, a cruel son of an evil father-Alexander Mackay-" The dark places of the earth "-Effect of missionary effort-Expulsion of missionaries-Murder of Bishop Hannington-Growth of Mohammedanism-Influence of native ChristiansRebellion, capture and death of King Mwanga-King David-Light and liberty.

$H^{R O M}$ the days of Speke and Grant to the present moment, every traveller who enters Uganda is amazed.

To reach it he has travelled through other countries and seen many peoples, but none just like these. From the coast to the Lake it was more or less chaotic, untutored savagery; but now he is face to face with a highly developed system of feudal government as an oasis in the 


\section{36 Uganda to Mount Elgon}

desert. This struck Stanley on his first visit, and he never ceased to wonder and express his high hopes and expectations of such a country and people ; and it is no exaggeration to say that could he have had his great desire to revisit Uganda, he would have realised how much his hopes and expectations were fulfilled.

Little, however, did the Christian world realise in the year 1875, when Stanley sent his memorable challenge, that behind the smiling welcome of King Mtesa there lay a concentration of cruel savagery unknown to the barbarian peoples so utterly despised by the Baganda.

The picture presented was that of an enlightened King whose very name meant "the arranger of affairs," presiding over a wellordered and industrious population of Negroids, i.e., a people neither wholly negro nor wholly Hamitic, but an admixture of the two.

The whole country was divided into provinces, and at the head of each province a chief appointed by, and directly answerable to, the King. These chiefs formed the Council of the country, and were presided over by the King.

The provinces were subdivided, and held in such a way that every piece of land and every soul could be accounted for. No one was independent, for each was owned by some one else who had powers of life and death. 


\section{Marvellous Organisation I 37}

The marvellous completeness of an organisation that could, at the sound of the King's war drum, transform the whole adult male population into an army ready to march whithersoever his Majesty commanded, was no more wonderful than the ordinary sights and sounds of this country as seen by the early travellers and missionaries.

They saw an alert and intelligent people of a colour ranging from light brown to jet black; with good physique and generally well-proportioned bodies, except in the case of some women whose enormous hips and breasts were supposed to be signs of beauty.

There were no signs of mutilation for the purpose of adornment, such as is common among the surrounding tribes with their filed and missing teeth, elongated ear-lobes, perforated lips, tongues, and noses, and cicatrisation of the body..

With the exception of the little girls, who wore a plaited waistband of coloured grasses, the whole population was clothed with graceful and becoming garments made from the bark of a wild fig-tree. The work of stripping the bark, beating it with grooved mallets of hard-wood, drying it in the sun and then sewing the pieces together, was that of the men, who, because of 


\section{38 Uganda to Mount Elgon}

this labour, have quite naturally taken the position of the nation's diressmakers.

The men were also responsible for the fighting and house-building, whilst the woman saw to it that the food supply was never short. The wife was the gardener of the family, and right well she did her work, skilfully tending the plantain grove which surrounded her little hut made of poles and thatch, and also cultivating the sweet potato, Indian corn or maize, peas, beans, and other vegetables necessary to make a change of diet.

With great care and cleanliness the green but ripe plantains were peeled, tied in leaves and boiled in the earthenware pot, then turned out and mashed-squeezed would be a better word-into a hot mass of pulp, which was served on fresh, clean leaves strewn on the ground.

No woman sat and ate with her lord and master, but received his commendation if the mass was good, and any pieces he might pass to her as she stood behind him. His feast was for himself and any male guests he chose to invite, and the women fed together with their children.

Politeness was noticeable as a marked trait of the Baganda character, and little courtesies between a man and his wife or wives were never neglected. The ladies turned out to meet and 


\section{Native Politeness}

welcome their lord returning from some raid in Usoga, Unyoro, or Toro; and from the congratulations heaped upon him it might have been supposed that he, and he alone, had won the battle.

"Webale! webale nyo ge! kulika musaja wange!" ("Well done, very well done you! bravo, my man!") resounded on every side; to which the gentleman replied "Awo!" ("Thank you!").

The man on his side never forgot to congratulate his wife on her cultivation and cooking; and these courtesies played an important part in the native life.

Some of the houses seen were of the most primitive character, resembling nothing so much as a haycock; but others, though of a curious shape to the eyes of a European, were always of great interest because of the beautiful way in which they had been thatched-a branch of work for which the Baganda have always been rightly famed.

Fowls, goats, sheep, and cattle seemed plentiful; and for the safe keeping of the first three the children were held responsible-not the progeny of the householders, for the Baganda, supposing it impossible to exact obedience from their own offspring, send them to be brought up by friends or relatives, whilst they make themselves re- 


\section{40 Uganda to Mount Elgon}

sponsible for the children of others and really bring them up very well.

The cattle were herded by a tribe of Hamitics, called Bahuma, who were practically slaves to the Baganda though related to the rulers and aristocracy of the neighbouring countries Unyoro and Ankole.

Apparently the people had all that heart could desire, and more than was good for them, for vast quantities of bananas were used to provide, not only the "Mubisi," or unfermented sweet wine of the country, but also the intoxicant known as "Mwenge," made by adding millet seed to the "Mubisi."

To outward seeming, then, the picture was one of happy contentment. That slavery was customary, and that women were looked upon as inferior beings, was well known; but it was inconceivable that the picture had another side almost too revolting to imagine or describe.

Mtesa and his chiefs were guilty of the most demoniacal practices, which account for the fact that the name by which he is known throughout the country to-day is not "Mtesa," the arranger of affairs, but "Mukabya," the causer of tearsa very appropriate name for the man who sold justice (!) to the highest bidder, brought cruelty to a fine art in the maiming of his victims, and wantonly murdered people to 


\section{"Habitations of Cruelty" I4 I}

appease a passing whim or the spirits of his ancestors.

Never was the scripture, "the dark places of the earth are full of the habitations of cruelty," so fearfully illustrated as in the history of Uganda, and that within comparatively recent years, although we speak of them as the bad old days.

Succeeded by his son Mwanga, the natives and the missionaries hoped for better things, but were doomed to disappointment. Weak, cowardly, and vacillating, the son proved himself all too worthy a successor to his cruel father, and the burden of the people became almost more than they could bear.

For some years I was in daily contact with a man who had been Mwanga's playfellow, and bore the marks of such dangerous intimacy. He had been entrusted to collect the King's revenue in the Province of Kyagwe, and on his return a discrepancy was discovered between his statement and that of the district chief. Certain sheep and goats could only be accounted for on the supposition that the King's messengers had had a right royal time on the homeward journey. Undoubtedly a dereliction of duty, but hardly sufficient to warrant the cutting off both ears of the chief messenger with a sharpened reed. 


\section{I42 Uganda to Mount Elgon}

One of my best native teachers was a man named Erisa, or Elisha-a big, fine man, who remembered Alexander Mackay, that splendid missionary, who did so much in his own quiet, plodding way to lay the foundation of the Church's successful work in Uganda. He remembered Mackay building the first brick house with panelled doors which were the wonder of all; but when I asked him to examine the house $I$ was then building, it was most pathetic to see him feel his way over it. He was blind; his eyes had been gouged out and an ear cut off at the bidding of Mwanga, because the King's drink, for which Erisa-then an unbaptized youth-was responsible, was not ready to hand when his Majesty called for it.

Both these cases constantly before me, and another which may still be seen, made me thank God that the time had arrived when such barbarities were impossible.

The third case was that of a woman whom I saw trying to hoe some sweet potatoes. There were others assisting, who willingly threw down their hoes to see and touch the white man. This particular woman stood back from the rest, until I intimated my desire to speak with all, when she drew near and shocked me by the awful sight of a woman indeed, but 


\section{Days of Persecution}

one without hands or lips. These had been cut off by her owner for some trivial offence, and there she was, pitiful to behold, as, ashamed of her condition, she endeavoured to do a woman's work.

May I once more say "the dark places of the earth are full of the habitations of cruelty"? And such cruelty that, in comparison, the above cases are as nothing.

The missionary toil of early days was beginning to take effect, and the King, realising that the minds and lives of his immediate followers were being influenced by the Scriptures and the teaching of the missionaries, issued an edict to the effect that all reading must cease under penalty of death; and then began the trial of strength between light and darkness, right and wrong, cruel oppression and progressive liberty, which lasted as long as Mwanga was on the throne.

The old tortures and mutilations became more numerous, and to these were added the brutal murder of those who continued to read the Gospel in spite of the King's edict.

Of course, many fled the country and took their faith and teaching to the people of Ankole in the west; but others remained and sealed their faith with their blood.

The missionaries were made prisoners, thrown 


\section{44 Uganda to Mount Elgon}

into a small thatched hut, left without other food than the few bananas given to them by kindly passers-by, and finally taken down to the Lake and sent adrift in native canoes, after Walker had been stripped of his clothing.

I often wondered afterwards, when visiting King Mwanga along with one of these victims, now Archdeacon Walker, just what was passing in each man's mind. Mwanga certainly never seemed comfortable; and how could he, remembering not only his treatment of Gordon and Walker, but also his murder of Bishop Hannington?

With the expulsion of the missionaries, he seemed quite certain of the death of Christianity and the growth of Mohammedanism, or at any rate such crude and cruel features of Mohammedanism as appealed to him. Yet, strange to say, he had to depend upon the very lads and young men whom he had threatened with death and driven into exile to fight his battles and protect his throne and person from the Mohammedans who made periodic bids for the capture of the country.

For four years I lived in and near the capital of Mwanga; was constantly in touch with him, and know something of the influence which the same lads-grown up as men, and, because of their reliability and integrity, made 


\section{A Sad Ending}

chiefs in the country-had over the life of the King.

He writhed under it, yet realised that for the stability of the country it was necessary; but eventually their determination to go a step further than the freedom of slaves and the extinction of cruelties was too much for his personal lusts, since they compelled him to expel from his presence the base characters who encouraged him in drink, treachery, and nameless vice. He rebelled against them and British influence, and the sequel was a lonely death on one of the Seychelle Islands.

So ended the conflict between light and darkness. The last representative of Uganda's pagan kings was buried in a far-off land, without the extravagant "Kitibwa" (honour) so dear to the heart of a Muganda.

No interminable procession with costly cloths to throw into the grave. No massacre of near relatives. No building of a national mausoleum on the site of the house in which the King had lived. No moving of the native capital to a place chosen by the new King. No processions such as he rejoiced to have, when the opportunity was taken by the new King, not only to view his predecessor's tomb and relics, but also to sacrifice a number of his followers. How vividly I have heard men who accom- 


\section{46 Uganda to Mount Elgon}

panied Mwanga on one of the visits he paid to his father's tomb at Kasubi, describe with what pleasure he gave an order to his gunbearers to follow him, carrying their loaded guns over the shoulder, and at his word pull the trigger and allow the charge to plough its way through the mass of humanity in the rear!

All this has gone, and not only because of the passing of Mwanga and his like, but because the Baganda as a nation have changed their point of vision. The "Lubare," or devilworship, responsible for gross superstitions and much suffering, is now scarcely known in the kingdom.

"Le roi est mort, vive le roi!" ("The King is dead, long live the King!") And for once the people really meant what they cried: for their "Kabaka," or King, although only an infant a few months old, had been baptized Daudi (David), and was to be brought up a Christian.

Long ago the directors of the Imperial British East Africa Company presented King Mwanga with a chair which served as a throne, and took the place of the one made by the native carpenter. The latter chair, with that of his father Mtesa, King Mwanga gave me just before he rebelled against the British Administration, and they are both now used in the study of the Bishop of Uganda. 


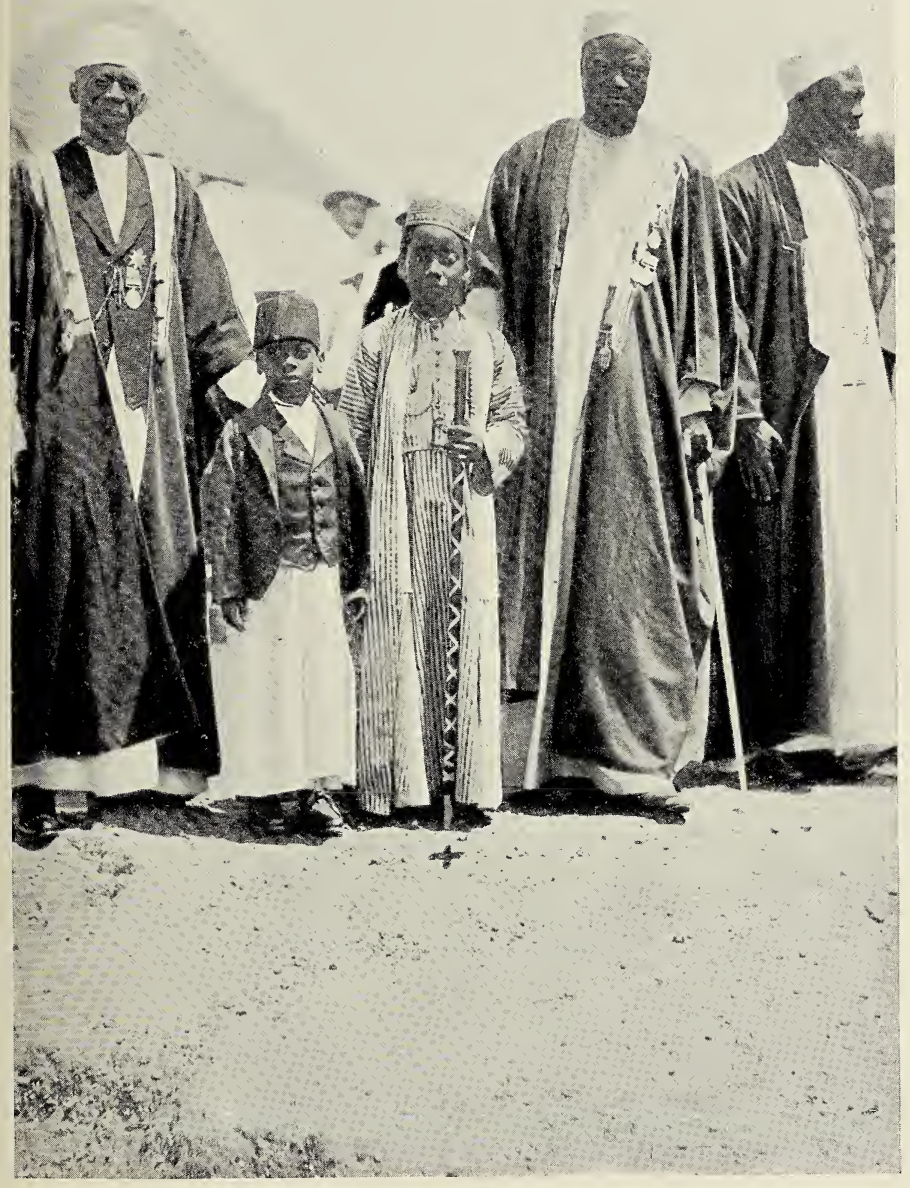

H.H. KING DAUDI (DAVID) CHWA $(+)$ 



\section{Light and Liberty}

To those who really knew Mwanga, nothing was more incongruous than to see him on his new throne, for just above his head was the carved motto, "Light and Liberty." The donors undoubtedly had their vision of things which to-day are being fulfilled, and the evidences of great advancement are thrust upon us as we make our way to the native capital of the present King, Daudi Chwa. 


\section{CHAPTER VIII}

\section{UGANDA : ITS PRESENT ADMINIS- TRATION}

No Uganda Railway-Porterage system-No relief for British taxpayer-Sir H. H. Johnston-Provincial chiefs-Pax Britannica-One Governor suggested for East Africa and Uganda-Tropical diseases-Native development or revenue -King David at home-Native parliament-Regents-Sir Apolo Kagwa, K.C.M.G.-Native capabilities and possibilities-Chamber of Commerce and Labour problem-Roadmaking-Waste of labour-Transport facilities--Need for technical education-Military service-Strategic position of Uganda-The Right Hon. Winston Churchill and the Baganda.

$\mathrm{N}$ nearing Mengo, we are surprised at the numberless porters leaving the capital for outlying stations, with loads of every description. We soon realise, however, that "Uganda Railway" is a misnomer; there is no railway in the country, and porterage is almost the only method of transport. I advisedly say "almost," because one or two private traders have 


\section{Reorganised Administration I 5 I}

recently introduced the bullock wagon with results far from satisfactory to either wagons or bullocks.

A closer acquaintance with the present system of government convinces us that the porterage system is only one indication that Uganda cannot be said to have advanced under British Administration-advanced, I mean, in such a way as to relieve the pockets of the British taxpayer, and, at the same time, so as to develop native character and self-support.

We have seen that in the days of King Mtesa the country was organised on feudal lines, by which the heads of provinces had power to try, fine, and, under certain limitations, kill.

This form of government was slightly altered by Sir H. H. Johnston when British Commissioner; and it cannot be claimed that the recent order whereby the Provincial, or Saza, chiefs are allowed to hold Courts and try cases is a development. It simply gives back an authority and standing which was taken away from them when, under the British Administration, they were turned into hut-tax collectors, for which they received the salary of $£ 200$ per annum.

This latter arrangement turned the revenue into the official coffers for the payment of salaries European and native; and the Muganda who forgets the real benefits of the Pax 


\section{52 Uganda to Mount Elgon}

Britannica (my typist wrote Tax Britannica, a mistake almost too good to correct), and complains that the white man is eating up the country, is told how much more English money is spent on administration than is received from native sources. Perhaps, like myself, he realises the lavish generosity of England, but thinks that it is too lavish in the wrong direction; and believes that the small kingdoms of Uganda, Unyoro, Toro, and Ankole could be more easily, beneficially, and cheaply administered by an English Adviser to the native kings; a Government land officer, a commercial agent, an English Accountant with various native clerks, all directly responsible to one Governor of British East Africa and Uganda, than by the building up of an intricate Whitehall system of bigger and lesser fleas who must be supported, development or no development.

We must not forget that Uganda is not, and probably never can become, a white man's country; neither can the Asiatic hope to make it his home. The climate may be temporarily possible for both, but in spite of the statement of such an authority as Sir Patrick Manson, K.C.M.G., \&c., that tropical diseases are not climatic, one may be allowed to say that without a tropical climate the intermediaries which transmit the germ-causes of tropical diseases 


\section{No White Man's Land I 53}

could not exist. They do exist, and indeed thrive under the conditions found in Uganda, and until those conditions are altered, as, for instance, the doing away with plantain-trees-a thing not to be dreamt of-we shall have mosquitoes, and if mosquitoes, malaria and all that malaria means to the white and Asiatic.

Bearing this in mind, we naturally think that development and not revenue should have been the watchword from the beginning-development of native resources for and by the native under European supervision. I am well aware that such a suggestion is pooh-poohed by many; first because they think it wrong, and second because they think it impossible.

A glance round the capital of Uganda will convince all who hold such opinions of their mistake, for on every hand are evidences that rapid strides have been taken to bridge the gulf between primitive barbarism and Western civilisation.

Large, well-built, and in some instances beautiful houses top the plantain groves; keen and varied business is carried on in the markets under the direction of a native superintendent. Here a butchery department, there a grocery store, hardware of every description, tailors busy at work with hand and machine making clothing for men and women, carpenters turning out 


\section{54 Uganda to Mount Elgon}

chairs and tables that would do credit to any British workman, all bespeak advance in the social life of the people, through crowds of whom, well dressed and orderly, we make our way to the hill from which the capital takes its name.

Here we meet the little King David, a boy of eleven years, who succeeded Mwanga, and although the "Lubiri," or reed-fenced enclosure of the King, has much the same appearance as in the old days, yet the moment we have been announced by the King's official drummer and passed through the various courtyards into the inner court, we perceive the great change which has taken place.

A snug-looking, brick-built bungalow has taken the place of the reed and grass monstrosity inhabited by Mwanga; and the visitor is ushered into a scrupuilously clean sitting-room, very simply furnished after the European style. There is no longer the sight of dirty, wickedlooking loungers, popping up from every corner like vermin from their holes; or the continual sound of lewd and ribald songs, discomforting the visitor but giving pleasure to the King, who was quite capable of delaying his presence in order to impress the European. The shy, pleasant-faced lad who now bids us welcome has been trained in a different school and is doing credit to his teachers. 


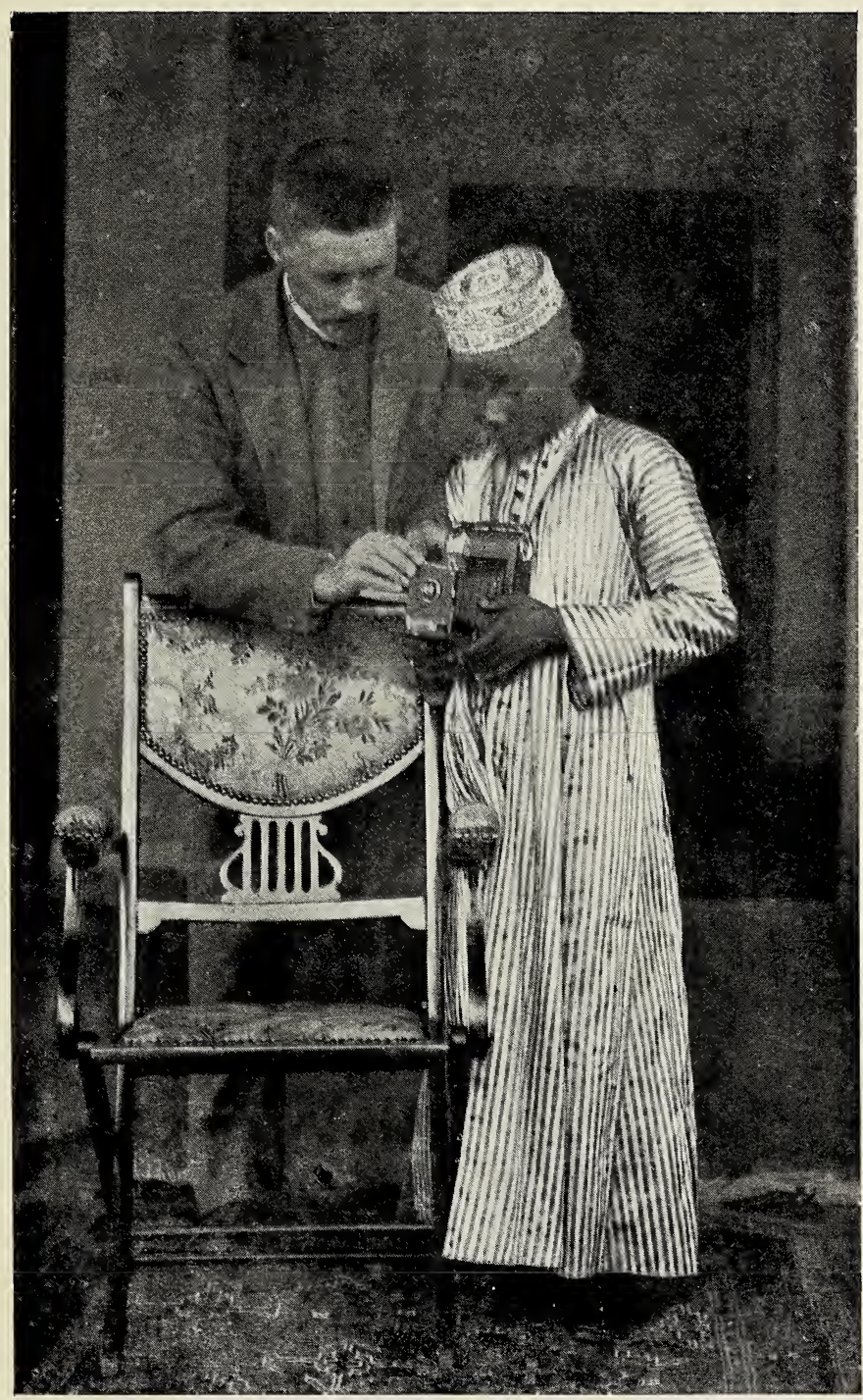

KING DAVID LEARNING THE MYSTERIES OF A KODAK. 



\section{King David}

Simply dressed in the flowing Arab robe which has been adopted as the dress-garment of all the chiefs, the boy-king carries himself with dignity, which on occasion he can shake off, and enjoy as any other lad a game of footer and hockey, or a spin on his Sunbeam cycle. $\mathrm{He}$ is also fond of riding his pretty little white pony: to European eyes a more dignified method of transit than the native custom of sitting astride the shoulders of a huge Muganda.

His education was begun by a native schoolmaster under the direction of a missionary of the C.M.S.; but the British Government has for some years past provided him with an able English (Scotch, surely!) tutor, a graduate of Cambridge. Under him Daudi has made rapid strides in all the elements of a sound education, and is especially proud of his ability to understand and converse in English.

On the same hill and in the King's enclosure is the native parliament house, where the chiefs assemble to discuss the condition of the country and promulgate laws, which may or may not receive the sanction of the British Governor. At present, and until he reaches the age of eighteen years, the "Kabaka," or King, is a minor; and three regents are responsible for the government, receiving for this an additional $£ 200$ per annum. One of these regents, the 


\section{58 Uganda to Mount Elgon}

"Katikiro," or Prime Minister, presides over the parliament, except on such occasions as the young King is brought in for the purpose of training. The Prime Minister, a capable-looking giant, was a notable figure at King Edward's Coronation, and has since been made a Knight Commander of the Order of SS. Michael and George. This man, risen from peasant rank, is the virtual ruler of Uganda, and responsible, perhaps more than any one else, for the great desire to advance along Western lines which has taken such a hold of the people.

There is a native proverb to the effect that the strength of a sheep is in its tail ; that behind all forward movement there is some one or something giving a powerful impetus; and this is undoubtedly true of the Katikiro, Sir Apolo Kagwa, K.C.M.G.; but of this power we shall speak in another chapter, since my object here is to point out not only the advanced desires of the natives, but their remarkable capabilities and the possibility of making them immediately responsible for every branch of administration, with only a comparatively small outlay for European supervision.

What would be lost by such an arrangement?

The collection of taxes is already in the hands of the native chiefs, and they are also responsible for the roads and markets. The Indian 


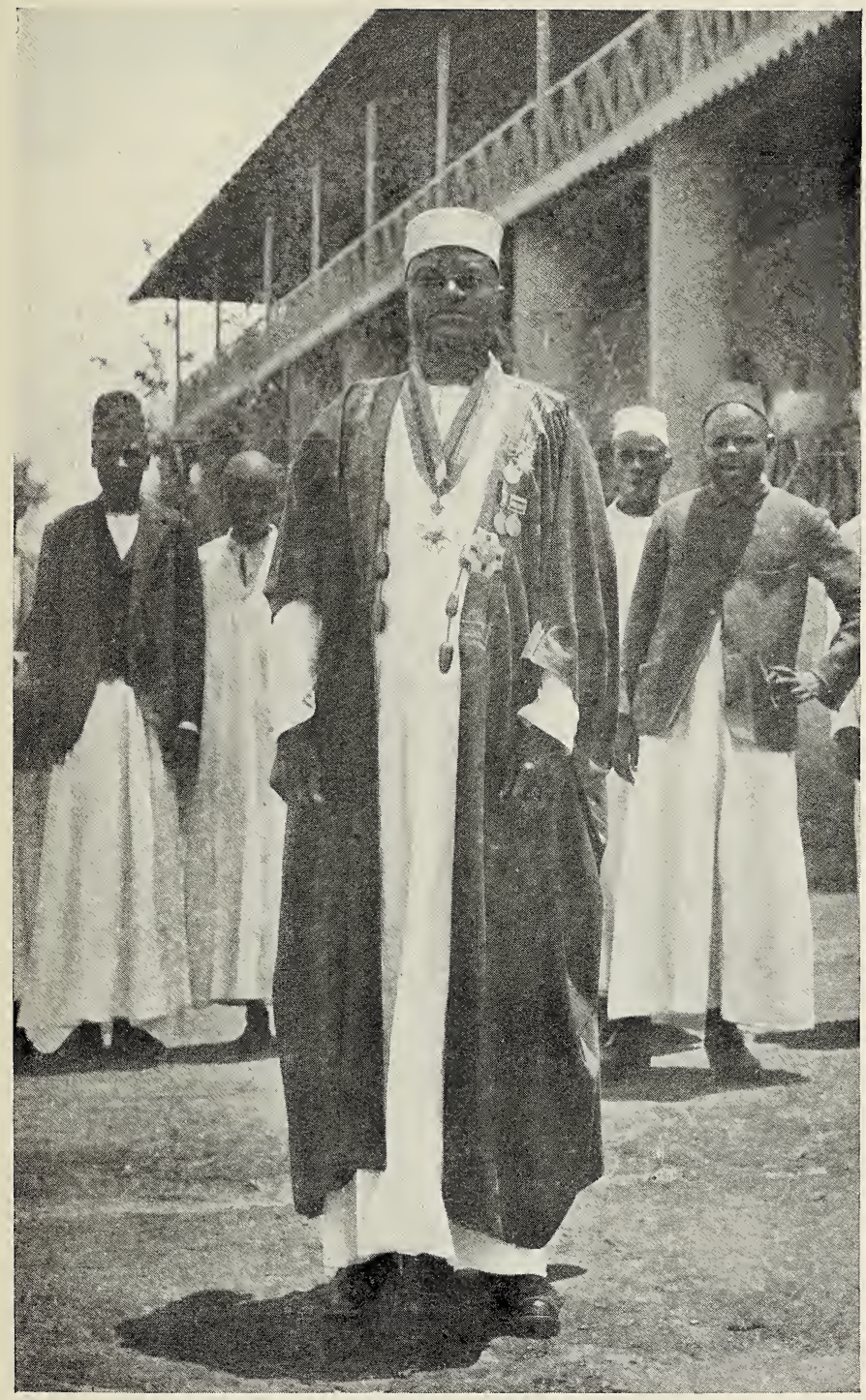

SIR APOLO KAGWA, K.C.M.G. 



\section{Lack of Industrial Training $16 \mathrm{I}$}

Penal Code is made possible by the help of native laws, although by such an arrangement there is a grave danger of too much law.

Nothing has been done by the Administration for the industrial training of the people. All education is carried on by missions, chiefly by the agents of the C.M.S., who also do the bulk of the medical work among the natives. We have in Uganda and neighbouring kingdoms comparatively as strong, if not a stronger, European staff of civil servants as that set apart in British East Africa for native work; and yet we have a letter like the following sent by the President of the Uganda Chamber of Commerce to the Acting-Deputy Commissioner:-

"I am desired by the Chamber of Commerce to forward you the following on the question of the critical and defective supply of native labour in Uganda.

In accordance with your suggestion a circular was addressed to every member of the Chamber asking for opinions as to cause, effect, and remedy, and though no unanimous views are held as to remedies, yet the opinions are generally as follows:-

Native labour in almost every South African colony is inadequate to the supply. But as regards Uganda in particular. 


\section{I62 Uganda to Mount Elgon}

Causes.

1. The natural richness of the country and the cheap and plentiful food and clothing supply.

2. The indolent life led by all Africans not subject to forced labour and oppressive legislation.

3. The increased demand for labour for industrial and trade purposes as well as for porterage, especially for through Congo carriage of loads.

4. Want of primary technical agricultural education.

5. Encouragement by Government and missionaries of local agriculture whereby the peasant is able to produce all he wants in the way of money from his own garden, as is seen by the great increase in the cottongrowing industry.

6. Absence of labourers who formerly came here from German territory.

7. Monthly payment of wages of a sum so nearly coinciding with the hut-tax.

8. Dislike of the peasant to work in the towns owing to the increased cost of living. The majority of men who came to earn money for hut-tax arrive generally entirely unprovided with money or food, and unless helped by friends, or they receive posho, practically starve themselves for a month, and feeling 


\section{Labour Problems}

this enforced punishment so severely that immediately they have received a month's pay return to their homes.

9. Sleeping sickness mortality preventing the growth of the population.

\section{EFFECTS.}

1. Persistent shortness of labour supply.

2. Gradual and regular increase of wages.

3. Loss to Government and merchants by delay.

\section{REMEDIES.}

1. Immigration. Inquiries have shown that large numbers of men are available in the neighbouring German territory. At Bukoba alone I am informed that five thousand men could easily be obtained at a day's notice. Would it not be possible to induce the Government of German East Africa to allow indenture of natives for work in Uganda under due safeguards for their return to the colony, and a payment by immigration agents to that Government corresponding to the amount of the hut-tax payable to the colony.

2. A census and registration of the adult native population through the chief's and registration for six months by employees. The right 


\section{I64 Uganda to Mount Elgon}

given to chiefs to punish by fine natives for not keeping to engagements or absconding.

3. A weekly wage experiment has shown that when the peasant receives a weekly wage he requires no posho, spends more, lives better, and is consequently a longer time in saving up sufficient money to enable him to pay his tax. The payment of posho and a wage at the end of a month is an encouragement for him to return to his country.

4. Encouragement given to minor native chiefs to exact rent, or labour in lieu thereof, for the house and land occupied by the peasant.

5. Improved roads to allow increased transport facilities by bullock wagon, which would relieve many thousands of men from Safari who are now merely beasts of burden. A calculation has been made by one of our members long resident in Uganda that at least 50 per cent. of the labour of this country is non-productive, and utterly wasted, in porterage, in water-carrying and in road-mending or making on an altogether primitive and wrong system.

6. The provision of primary technical schools for agriculture, trade, road-making, \&c., which would help to induce the males, and especially the younger generation, to desire a more regular manual labour." 


\section{Administrative Breakdown $\mathbf{1} 65$}

It is not necessary to agree with every point in the letter to realise its value, as emphasising the fact that there is a serious breakdown in the general administration of the country-and a breakdown, not in spite of, but more probably because of the dual form of administration; the Western as represented by English officialism not daring to Westernise enough, and the feudal as represented by the native "Lukiko," or Parliament, holding things together. Indeed, without its capable co-operation the present peaceful organisation would undoubtedly collapse.

One really striking statement in the letter is-" A calculation has been made by one of our members long resident in Uganda that at least 50 per cent. of the labour of this country is non-productive and utterly wasted in porterage, water-carrying, and in road-making or mending on an altogether primitive and wrong system."

No greater condemnation than that contained in this passage could have been passed upon a native administration; but this is passed upon the British, and deservedly so, for I believe that if a man like "Bwana Tayari" (Sawhili name, meaning "Mr. Ready," and used by the natives when speaking of Mr. George Wilson, C.B., Deputy-Governor of Uganda) had been allowed to generally superintend and direct the gradual and natural evolution of the feudal system, we 


\section{66 Uganda to Mount Elgon}

should not have had what is now acute-a native labour problem.

The "wrong system" of road-making can be seen in operation throughout the Protectorate. Hundreds of men, women, and children are required in the first instance to cultivate the portion of the country that has been pegged out as a proposed road by one of the white officials. It may be ten yards wide or it may be thirty; it may be straight or it may be crooked; it may satisfy one official and be left to die by another, who will call upon the chief to do all over again elsewhere what is after all only a heart-breaking job, for such a road must be constantly kept weeded to prevent its being lost sight of.

Naturally the people soon get tired of such unending labour, and many of them leave the homes of their fathers because situate near a road; and large tracts of land, once well-cultivated gardens, have been given up to long grass and leopards.

Now, and not the dim and distant future, is the time to improve the roads, for every year the native is in touch with so-called civilisation brought in by the Uganda Railway, makes him more difficult to deal with and more expensive to employ.

Each chief and people of a district in the 


\section{Cultivation versus Macadam 167}

Uganda and adjoining kingdoms, as well as in the country of Usoga, where the natives have been under European influence for some years past, might be made immediately responsible for the construction and maintenance of macadamised roads. The time spent in breaking stones by a few hundred men in each district would eventually prove an enormous saving in time, temper, and labour. Attempts have also been made to utilise certain waterways for the conveyance of merchandise; and there again the "wrong system" was seen at work. At one time large gangs of men have been employed in cutting down papyrus and clearing away the sud; but gradually the workers disappeared, and the work was allowed to drop until the growth was as thick as ever, when the labour of clearing was begun all over again.

Definite and sustained effort is badly needed in order to perfect transport facilities, and were it made known that all taxation would cease for one year in any district occupied with roadmaking, with proper punishment of harder labour for individuals refusing to do their part, the transport problem would be solved, because wheeled traffic would be really possible. Another very important point touched on is the lack of technical instruction. Not a single penny has been spent by the Administration on technical 


\section{I68 Uganda to Mount Elgon}

instruction. Had this been done not only would the males of a younger generation have had a keener desire for regular manual labour, but the present generation would have solved, and will even now solve if taught how, the most pressing problems. If the idea behind British administration in Uganda is not the farming of taxes, but the true development of the native and his country, then I plead most earnestly that technical schools for the teaching of trades and agriculture be established by Government in each district, and that every boy and girl be compelled to attend for no less a period than three years.

The calm way in which the Government relegates this and all other education to the Christian missionary, making suggestions here and requests there, would be most amusing-in the face of an education problem at home-were it not deplorable. In a country like Uganda and neighbouring kingdoms, where there is native desire for advancement, and organisation already in existence to enable the head of the State to deal with each individual, and a very substantial revenue, it is the duty of the Government and not the privilege of missions to spend money in seeking to develop this side of native character. The writer would be sorry to convey the idea that he does not recognise the inestim- 


\section{Income and Expenditure 169}

able value to Uganda of England's protection, brought about in the year 1894 through the influence of the C.M.S. ; but we must not forget that there are certain compensations given in return, which lay responsibilities and obligations upon the protecting Power.

Out of a computed 19,600 square miles, the British Administration took as its own under the 1900 agreement 1,500 square miles of forest land, and claimed control over 9,000 square miles of uncultivated land, which really means that we have taken more than half of the land for being willing to protect the remainder, and then of course we make the remainder pay as much as possible of the cost of protection.

For 1907 the receipts for the whole Protectorate, from hut, gun, and poll taxes were between $£ 50,000$ and $£ 60,000$. Besides this amount there were import and export, road and wharf dues, registration fees, licence fees, \&c., \&c., bringing the total to a goodly sum, the expenditure of which-with additional grants from England-provides not only interesting reading but material for serious reflection.

Some $£ 6,000$ is returned annually to the King and chiefs of Uganda under the above-mentioned agreement, whereby, as we saw at the beginning of this chapter, the chiefs became in return simply hut-tax collectors. To this, as we 


\section{70 Uganda to Mount Elgon}

have seen, the Administration has found it necessary to add much of their old feudal power, and to-day there are no more hard-working, painstaking, and loyal men anywhere than the Saza chiefs of Uganda; yet I have heard men gravely discuss whether we are justified in paying these chiefs their $£ 200$ per annum, which is $£ 50$ less than the allowance to a raw assistant collector fresh out from England.

In my own mind the doubt is whether in a Protectorate like Uganda, with such native material ready to hand, infinitely more capable than raw youths from England of doing collectors' and magistrates' work, we are justified in paying any but native officials, with, of course, the exception of white leaders as I have already suggested.

If only in addition to the $£ 6,000$ spent on stipends to the King and chiefs, an additional $£ 10,000$ could be spent annually for the next ten years on providing a commercial, technical, and industrial training for picked youngsters drawn from the whole Protectorate, how much more good it would do than, say, the building of an expensive military system; and surely such technical training is far more important.

The letter from the Chamber of Commerce failed to mention that whilst in England the wages of a private soldier-including everything 


\section{The Strategic Value of Uganda $\mathbf{\text { I }}$ I}

-are about equal to those of a labourer, in Uganda they are about three times as much; so that a careful native who joins either the policewho do military work-or the regular army, can, during the first term of service, save as much as will enable him to pay hut-tax and meet all his needs for many years.

Thus we have a native problem growing more pressing and difficult every day; and is it any wonder?

The strategic position of Uganda is another valuable asset of England, and it must be held; but it would be wiser and cheaper in the end to hold it by Sikhs only, than at this stage of Uganda's history to enlist the native, and, by an unhealthy rate of pay, jeopardise the development of the country.

Let it not be thought for a moment that my criticism of a system means a criticism of the British official, or a suggestion that he is at all incapable. As in every class of men, there are no doubt good, bad, and indifferent officials ; but my experience is chiefly of the good. They are men who find a system in existence and try to make the best of it; but would it not be better for them and for the Protectorate if the system were altered so as-to quote the Right Hon. Winston Churchill, who, as Under-Secretary for the Colonies, recently visited Uganda-"to 


\section{I72 Uganda to Mount Elgon}

organise scientifically, upon a humane and honourable line, the industry of an entire population, and to apply the whole funds of their labour to their own enrichment and elevation"?

The British official would still be required to open up the vast regions north and north-east of Uganda, leading right away beyond Lake Rudolph to the borders of Abyssinia. 



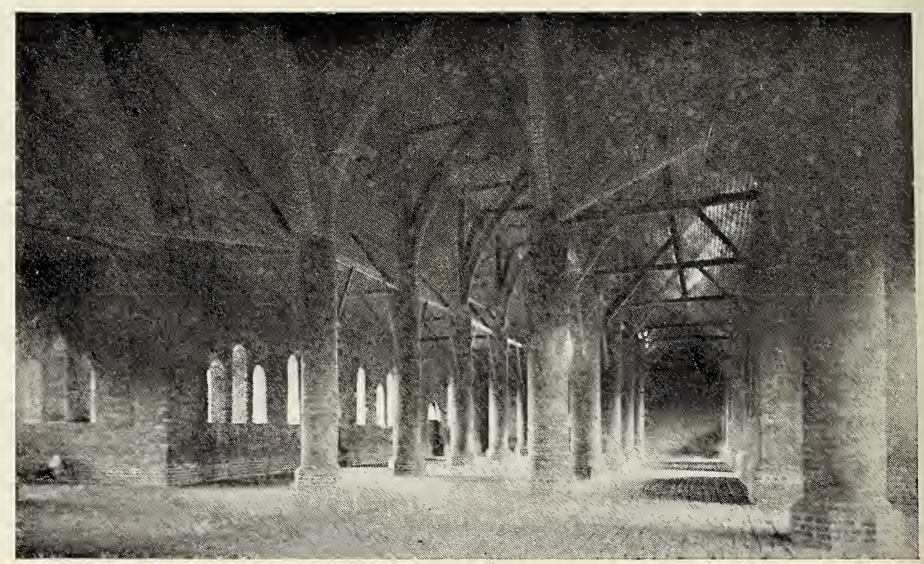

INTERIOR VIEIV OF MENGO CATHEDRAL.

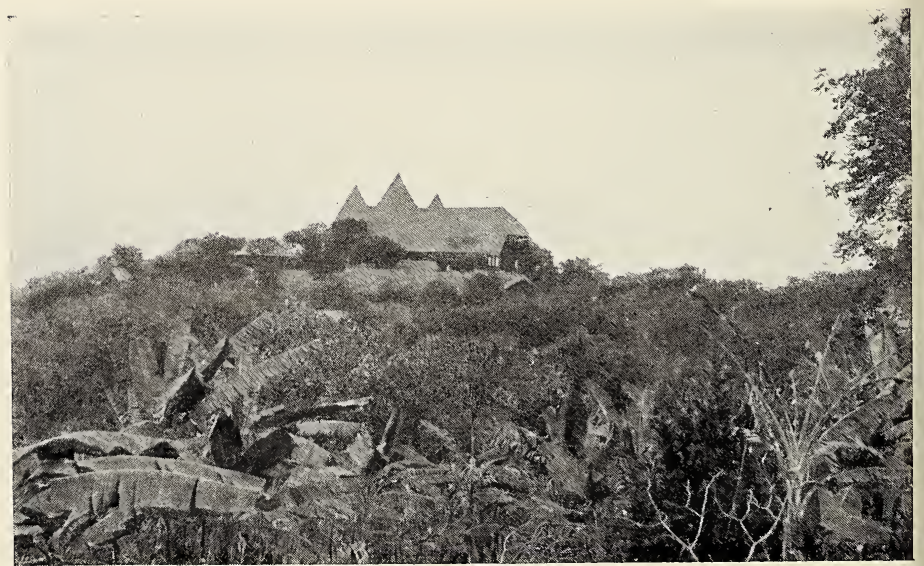

ST. PAUL'S CATHEDRAL, MENGO, UGANDA. 


\section{CHAPTER IX}

\section{THE SIGHTS OF MENGO}

Kampala - Nakasero - Uganda Company, Ltd. - Philanthropy and percentage-Cotton ginning and balingStones sold at cotton price-Uganda newspapers-Roman Catholic Missions-Roman disunion-C.M.S. headquarters -The Cathedral and congregation-The Uganda drum -Missionary meetings-God's Acre-The Soudanese Rebellion-Sad days-Mengo Hospital-High School-The Bishop's Palace.

$f^{\text {ROM }}$ the King's hill, although not very Ligh, interesting and picturesque glimpses of the capital can be secured.

Behind us lies the Lake; and soon, I have no doubt, the port of Uganda will be Munyonyo, a place not more than eight miles from Mengo, safe for shipping, and more suitable and convenient in every way than Entebbe, which is more than a comfortable day's march from where we stand.

Here, outside the King's fence, we can see 175 


\section{76 Uganda to Mount Elgon}

the little hill of Kampala, which was the first Government station in the country; and curiously enough, because of this, the name of the little insignificant hillock now occupied by a Commission sent out to inquire into the ravages of Specific Disease has been made the postal and geographical name for the native capital.

Some years ago the local administrative centre was moved from Kampala because of its unhealthiness, to Nakasero, a high hill near, on which is built the English fort. Here also may be seen European and Indian traders, catering for the taste, inclination, and need of native and white man, with every conceivable article.

Near the foot of the same hill is built the factory of the Uganda Company, which was floated to take over and develop on practical business, yet Christian, lines the industrial work of the C.M.S., for which more money could not be spared.

With such a philanthropic aim it secured the practical sympathy of many Christian people, and also received considerable help from the C.M.S., who allowed one of its missionaries to transfer his services to the Company as manager, which at once gave it a unique advantage over ordinary concerns. 


\section{The Uganda Company 177}

On the whole it has done a good work, though not quite on the lines expected by many; but no doubt any failure to develop its industrial work actually on the lines of a Christian Mission has been due more to the force of circumstances than lack of inclination.

If for nothing else, the Uganda Company deserves well of England, because of the impetus it gave to cotton-growing before any one else had moved in that direction; and a visit to the factory, built at great expense-the greater because the first of its kind, and all such ventures must pay for the privilege of handing down experience-is both interesting and instructive.

A complete cotton-ginning plant, worked by steam-power, controlled by the Baganda under the superintendence of Englishmen, can be seen in operation, whereby the whole process from seed extraction to bale-pressing is carried out without a hitch; reflecting the greatest credit on the manager who was responsible for its erection.

This and other factories have now taken their place as an accepted part of Uganda life, and crowds of natives come in from long distances with loads of raw cotton, for which they receive about a penny per $\mathrm{lb}$.

Some two years ago there was such a rush of 


\section{7 Uganda to Mount Elgon}

cotton that the agents feared they would have to refuse it for lack of storage room. Tons came in every day, and might have continued to come in even with a greater rush had a casual examination not proved that the Baganda were not such innocents as the management supposed. A penny per lb. for raw cotton leaves a fair margin for all expenses, and a good healthy percentage besides; but when quite three-quarters of each $\mathrm{lb}$. is composed of stone-well, some one is likely to "see trouble," as the Baganda express it.

It was so easy to put a lump of ironstone in the middle of a bundle which was merely weighed; and the consequence was that a good many stones were bought at cotton price!

It was also comparatively easy to walk round the building with the load of cotton which ought to have been deposited inside; consequently a goodly number of Baganda walked round the building with their loads and resold them to the innocent agent at the scales!

There is also a printing department at the works of this Company, and I hope the ancient borough of Stockton-on-Tees, with which I am at present connected, is justly proud of the fact that it has provided the superintendent of this department. Each month I receive a little journal from Uganda-for that country has 
now two newspapers, or at any rate monthly pamphlets which serve as such: one, Uganda Notes for Europeans; and the other, Ebifa Ebuganda, Uganda news for natives, ably edited and published by Mr. C. J. Phillips, a member of the C.M.S.-admirably printed by Baganda boys in the works of the Uganda Company.

In another shop of the Company, and in sheds throughout the capital, native men and boys are at work upon boards that have been sawn in the forests by other natives, and brought to Mengo for sale. These are speedily made into tables, chairs, doors, shutters, frames, desks, and bookshelves, and turned out in fairly good style, though lacking that finish which bespeaks the master-hand : a fault for which the lack of long apprenticeship is responsible.

Not far from the factory the Company has its store for the retailing of imports ; and this, perhaps, is the only department to which any exception can be taken. It may be argued, with some show of justice, that this department brings a professedly philanthropic enterprise, which has received unique advantage over other trades through the help rendered by the C.M.S. and its agents, not only into competition, but into unfair competition, with other traders; yet in this department the Company and the country have been fortunate in 


\section{80 Uganda to Mount Elgon}

securing the services of a manager who remarkably carries out in his own life and work the primary aim of the Company, namely, to try in the course of ordinary business to influence and elevate the native.

To the right of Nakasero, and where we stand, can be seen the hill of Nsambya, the Uganda headquarters of St. Joseph's Mission : a branch of St. Joseph's Society for Foreign Missions founded at Mill Hill, London, by the late Cardinal Vaughan.

The first Bishop of this Mission left London with four priests in May, 1895, the same month in which I left with others to begin our journey. The priests reached Mengo in September of the same year, and we arrived at the end of October, having travelled round the Cape of Good Hope.

This Mission has over twenty thousand baptized adherents, many of whom were passed over to it with the portion of Uganda allotted to its Bishopric from the jurisdiction of the French Algerian Mission of the White Fathers, whose local headquarters are very prominently and substantially built on the hill of Rubaga, situate on our left as we stand at the King's Gate.

This latter Mission has had an interesting, aye, even exciting time in Uganda, for it is the one whose adherents clashed with those of the 


\section{Roman Catholicism in Uganda $\mathbf{I} 8 \mathbf{I}$}

C.M.S. in Lugard's time over the question of whether the country was to be French or English ; and it is almost pathetic to think that its reward has been the French Ecclesiastical Coup, from which I understand it only managed to save its Algerian property by its transference to lay holders, and the setting up in the capital of Uganda of another Roman Catholic Bishopric with which it has had to share its honours.

Apropos of Roman Catholicism in Uganda and East Africa, I was recently asked why the C.M.S. had not a working agreement with lines demarcating spheres of influence. I explained that this was done for the Mission in the Soudan by the Government, but with us since Government has not marked off spheres, and since the C.M.S. was first in the field, it would be impossible: the Romanists would not agree to any such arrangement. I gave a very striking example of Roman Catholic nonconformity-or at any rate disunion-which is even now going on near Lake Naivasha, where certain priests have appeared from the Somali coast, and are threatening the Bishoprics of the Uganda and Zanzibar Roman Catholic Bishops, who are doing their best to keep them out.

To return to our stand outside the King's Gate; we see right in front of us the English Cathedral on the hill of Namirembe; and a 


\section{82 Uganda to Mount Elgon}

weird yet striking edifice it looks, with its three thatched pinnacles, all in a row, like the prongs of a giant's trident. Thither we now make our way, and find it the centre of activity, for the hill is the headquarters of the C.M.S. Uganda Mission, whose agents are to be found at Wadelai, in the north, Nassa, in German territory, to the south, beyond Ruwenzori in the west, and beyond Mount Elgon in the east.

The present cathedral is the third which has occupied the site during the last few years. The two former were miniature forests; for innumerable poles were planted in the ground and used to support the woven canopy of poles and reeds which carried the thatch. They were very useful buildings, but risky; for no pole seemed beyond the appetite of the white ant, and the result was a somewhat speedy collapse.

The building we are now viewing is a tremendous advance on its predecessors, though scarcely a permanent structure. It is made of sun-dried bricks, and is altogether the work of the natives under European supervision. Externally it is not a thing of beauty, but a glance at the photograph of the interior on p. 174 will show that its lines and proportions are bold and noble.

The ordinary Sunday morning congregation 


\section{A Magnificent Congregation $\quad$ 8 83}

is a sight worth seeing, for often there are not less than two thousand people, old and young, rich and poor; some on chairs, others on stools, skins, or straw mats. Only the chancel is provided with seating, so that the general congregation, white or black, must bring their own seats if they wish to be raised above the level of the floor. May the system long continue!

Many beautiful skins of leopard and antelope are seen being carried to and from the church; and this reminds me that recent writers have said that the Baganda are noted tanners. They are nothing of the kind; the Baganda do not know how to tan, but they are remarkable skin-dressers, in the process of which they make a liberal use of a knife, a stone, and butter.

The congregation is summoned by the beating of a drum or drums-a very important factor in the life of a Muganda.

In the old days the King's drum was sounded to summon men to war; and so perfect was their organisation that its sound and summons was passed on from hill to hill, so that before evening every warrior in the country was under arms and on his way to the capital, there to receive the appointed general, who would lead the army wherever the King wished 


\section{84 Uganda to Mount Elgon}

them to make a raid for cattle or human beings.

The sound is still passed on, but now from Namirembe, the hill of peace; and at its summons full sixty thousand people assemble to render homage to the King of kings, or to go forth among the very nations who hate the Baganda for their past oppression, to make known to them the Gospel of light and life and liberty.

The morning service may seem somewhat lengthy to a European, but he will not fail to be impressed by the reverence of the congregation, their bright and hearty-if to his ears unmusical-singing, and by the large number of communicants.

One or two native clergymen assist at the service, and it is no unusual thing for a layman to preach the sermon, which I can assure you is of fifteen minutes' duration-and more.

The visitor will also be interested and amused at the process of evolution evident in the attire of the congregation, and he will understand that such absurdities are bound to show themselves even at solemn times and in sacred places, when a nation unused to such things is suddenly given the means of displaying its most fantastic tastes in colour and shape. 


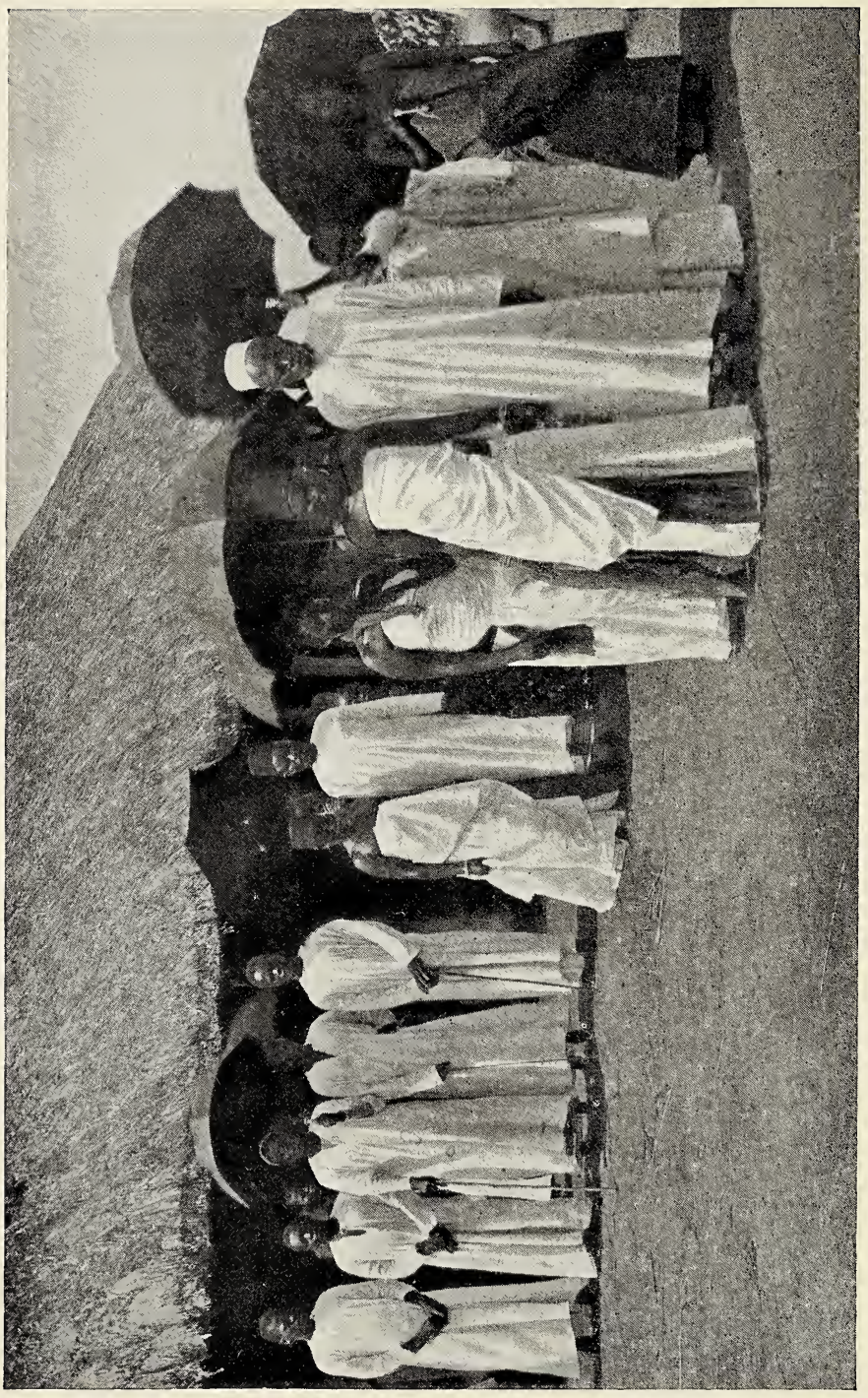

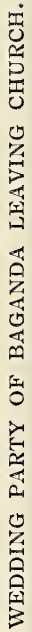




\section{Native Missionary Meetings 187}

A glance at the accompanying picture of a wedding party leaving church will show that their taste is not always extravagant or unbecoming. The only thing at all objectionable is the lady's tarbooch, or Turkish cap-one stage in the evolution which I am confident will soon pass away.

The cathedral is surrounded by other buildings, in which the ordinary work of schools, preparation for baptism and confirmation, and the training of teachers is carried on.

There is a fine school for girls, another for women, and another for boys, all built of sundried brick; besides which there is an imposing structure of the same material used as a theological hall, in which the teachers and clergy are trained.

The work carried on in these buildings is of an extensive, interesting, and useful character, beginning at the very bottom of the ladder with A B C, and going right on to the higher branches of theology.

On one day of the week all this teaching ceases, and the members assemble to take part in a missionary meeting, at which natives, who have been labouring in distant corners of the Protectorate, tell of their work.

Not a detail is omitted. The number of sermons preached, the attitude of the people, 


\section{88 Uganda to Mount Elgon}

the kindness or otherwise of the chiefs, the dangers encountered, the presents received, the amount of food eaten, are all retailed with an exactitude most amusing to a foreigner; but besides this there is in some of the addresses a deep spiritual tone which is the real life of the movement.

At the close of the addresses an offertory, more varied in kind than the English mind can conjure up, is made: bananas, sugar-cane, eggs, fowls, goats, sheep, cattle, shells, beads, pice and rupees are all given, and it is no uncommon thing for natives to offer themselves for work in distant and difficult places, although $I$ think this is not now so usual as at one time.

On the side of the same hill is the C.M.S. Hospital, which was founded in 1897 by Albert R. Cook, M.D., B.Sc. Lond., B.A. Camb., who was soon afterwards joined by his brother, J. Howard Cook, M.S. Lond., F.R.C.S. Eng., M.D. Lond., D.T.M.H. Camb.

To reach the hospital we pass the little plot where lie the remains of Bishop Hannington, Pilkington, Hubbard, and others of the C.M.S. Mission, and De Winton, Thruston, Macdonald, Densham, and others of the Administration. Noble souls, all of them !

What memories surge up as we pass their 


\section{The Soudanese Rebellion I 89}

resting-place! We live over again the night in 1897 when news came in that Thruston, Wilson, and Scott had been taken prisoners at Luba's in Usoga by the Soudanese soldiers who had refused to follow Colonel (now General Sir J. C. R.) Macdonald on his journey north with sealed orders, and had marched back from the Ravine Station on to Uganda.

These men were ever a bad lot, having rebelled against the Egyptian Government, and when serving Emin Pasha had held him prisoner until relieved by Stanley.

With their leader, Selim Bey, they were enlisted in the Lado Enclave by Lugard, and placed in charge of the Uganda border forts, where they were a greater curse than any number of enemies might have been, since under Selim Bey they were a Mohammedan menace to the peace and stability of Uganda, until they were enrolled as Imperial troops.

But their old nature was too strong for them, and now from the fort at Luba's near the Nile they had despatched messengers to all the soldiers throughout Uganda, calling upon them to kill the white men and take the country for Mohammed. These emissaries had reached the lines at Kampala, and we were warned that before morning we should probably be attacked and killed. In the event 


\section{I90 Uganda to Mount Elgon}

of no attack we were to make our way to Kampala Hill next morning and there help to disarm the soldiery who could no longer be trusted. We did so and succeeded; but in the meantime grave things were happening at Luba's, for the rebels there, having been repulsed by Colonel Macdonald, had brutally shot their three white prisoners, Major Thruston, Mr. Wilson, and Mr. Scott.

Then came the news of the fruitless attack on the rebel fort by the brave Protestant Baganda (most of the Mohammedans were wavering or had already thrown in their lot with the Soudanese rebels, and many of the Roman Catholics had thrown in their lot with the rebellion of King Mwanga in the west), and of the death of Captain Macdonald (the Colonel's brother) and Mr. Pilkington.

It fell to my lot to speedily build the first hospital, to meet the wounded who were sent by canoe, and get them carried to the capital, where Dr. A. R. Cook worked day and night, ably assisted by the Mission ladies, to alleviate the terrible sufferings, that had been intensified by a long delay en route.

Graves had to be dug for the Europeans killed in Usoga, a coffin made for Pilkington's body-the Government made others for their own men-and then there was that last sad 


\section{The C.M.S. Hospital I9I}

and solemn scene when they were laid to rest "in sure and certain hope of the resurrection to eternal life, through our Lord Jesus Christ."

The roses are blooming on their graves, and sweetly speak of life, yet we cannot help but linger, and picture it all asain; but now let us wend our way outside the wall and down the hill to the hospital.

The first branch of the medical work met with is the dispensary, known as the "Wellcome Dispensary," a substantial and very useful building where cases are diagnosed, medicines dispensed to thousands of out-patients, for whom evangelistic services are held in a verandah at one end of the building.

The hospital itself is a more pretentious structure with wards, pathological laboratory, and operating-room that will compare very favourably with a similar institution anywhere.

Bodies and souls are well catered for, and here, if anywhere, can be refuted the nonsensical argument that it is unfair to speak to natives about their souls when their bodies are in need of healing.

The Baganda patients soon realise that but for the fact that the doctors and nurses are impelled by the love of God in Jesus Christ to care for them, they would never have come out to the country; and if their Christian 


\section{Uganda to Mount Elgon}

doctors and nurses had not come, who else would have thought of them?

The doctors are perfectly fair to every patient. All are taken in and attended to; and if there happens to be a Roman Catholic, the Mission to which he belongs is communicated with, and they are allowed to help him spiritually. That such work is appreciated by the Roman Catholics may be evidenced by the fact that they have more than once sent donations to the funds.

After a walk through the wards we make our way round the hill to the Mengo High School-a feature of the C.M.S. work at the capital.

Inside the usual reed fence is a large courtyard, along the sides of which are built boarding-houses for young chiefs, or sons of chiefs, who are removed from the evil surroundings of home and placed in this school to receive a sound mental, moral, and spiritual training.

The ability shown by the majority of these youngsters is remarkable, and will compare favourably with that of lads at home. In some subjects there is not the least doubt but that the black can "lick" the white boy hollow; thus proving that, given opportunity, the Baganda, in spite of their colour, might be made anything. 


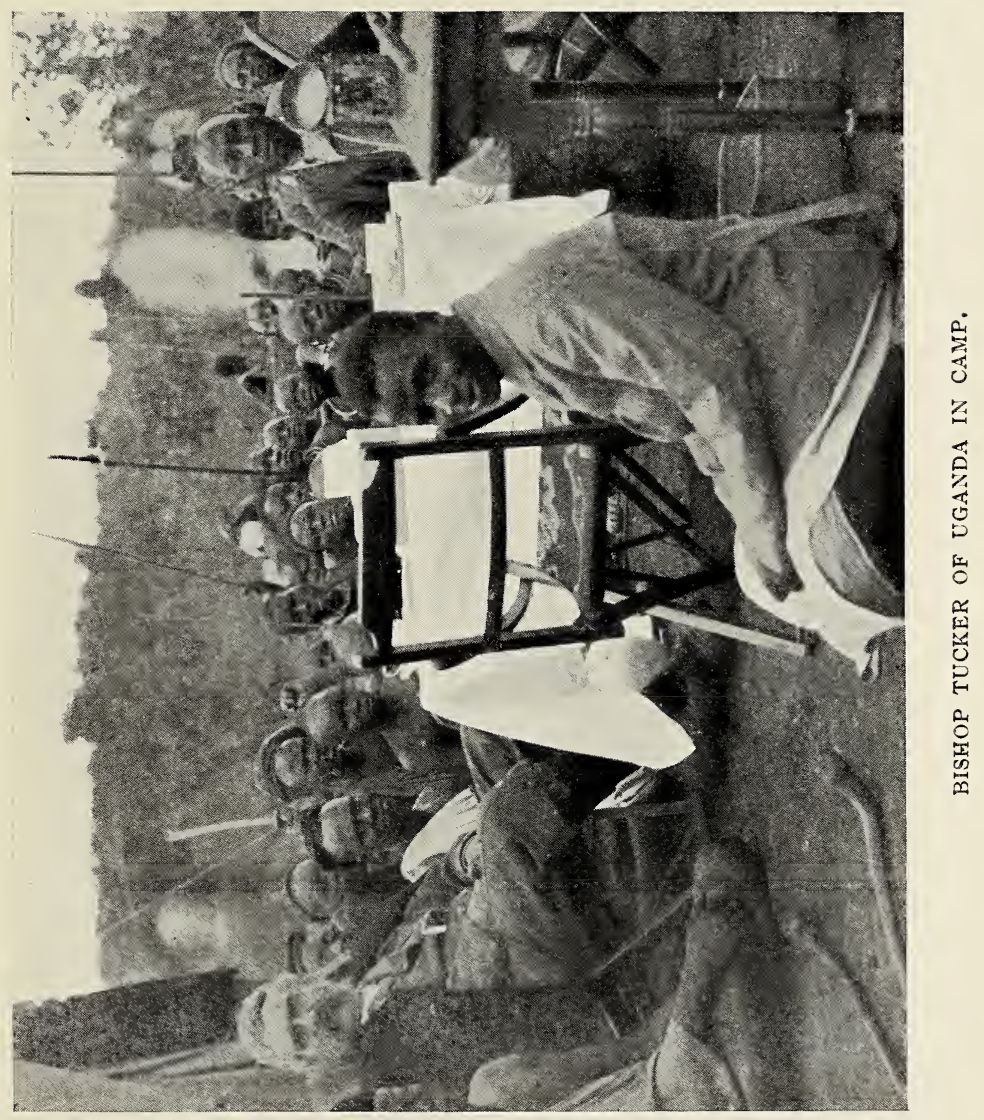





\section{The Bishop and His Palace 195}

The three R's, English, physical exercise, swimming, cycling, tennis, footer, Bible and Prayer Book, are all taught and excelled in.

There is another important school called the King's School, situate at a place called Budo, some distance from the capital, and some of the boys from the Mengo High School pass into the other on scholarships; but enough of this subject for the present; let us pass on and complete our round.

We began with the capital of British Administration, the home of the Governor, and made our way to the native capital and home of the King; and we close this chapter at the palace (!) of the Bishop of UgandaDr. Tucker, who has just completed the eighteenth year of his episcopate-a native-made wattle and daub, thatched bungalow, wellworn, weather-beaten, and ready to fall, but still tenaciously held by his Lordship, as an example of what will suffice whilst more important things are being attended to. 


\section{CHAPTER $\mathrm{X}$}

\section{THE WORK AND INFLUENCE OF MISSIONS}

True Socialism-The life of women-Native missionariesCondition of the Church-Appalling numbers-Numerical not necessarily moral strength-Danger of numbersDanger of civilisation-The housing problem-Superficial character-Evil living-Johnston's opinion as to Uganda's need-A Puritan revival-Secular education-Desire for knowledge-Intelligent people-The education problemDuties of Church and State-Church government-White missionary not permanent-A constitution-Self-support and self-extension-Lack of funds and permanent buildings -The crisis of the nation and the Church-HopeQuestions of Church practice and discipline--Organisation -A division of the diocese.

THE missionaries of Uganda have always 1 striven to implant in the native mind the corporate idea of one family in God; and the truly socialistic because Christian idea of man's duty to his fellow-man. Their work has lifted woman from a position of degradation and 


\section{A Modern Miracle}

scorn and made her accepted throughout the kingdom as the equal of man. It has made family life as sacred a reality to many as it is in England; it has increased the value of human life and given to individuals, once thought too insignificant and loathsome to be noticed, due recognition as men and brethren. Indeed, no one who knows the African nature, or who has carefully compared the condition of Uganda before the introduction of missions, with its condition at the present day, can help but declare its firm conviction, that we are face to face with a modern miracle.

To see men clamouring to leave home, friends, food, security, and chances of advancement to go to unknown and inhospitable countries in order to preach a Gospel which to them was more precious than life, and for which they received little or no remuneration, was enough to convince the hardest sceptic of their sincerity; yet this was a common sight a year or two ago. The wonderful Church-building and peoplenow existing in the country of Toro near the Mountains of the Moon is due in great measure to the pertinacity, sincerity, and intrinsic goodness of one such man; but the question is often asked, "Are the Christians of Uganda willing to do the same to-day?"

In some instances Yes, emphatically. No 


\section{I98 Uganda to Mount Elgon}

more striking instance of self-sacrifice can be given in the world's history than that of the woman teacher who, hearing that the people of a certain island were dying of sleeping sickness and were without any physical or spiritual assistance, offered herself for the work; and although efforts were made to dissuade her from undertaking such a task, she insisted on going to live and, if need be, to die (eventually she did die of sleeping sickness) for her fellows-but generally speaking the answer must be No.

There is still life, strength, and effort of a high character; but there is a change in the attitude of mind and will, due very largely to the changed economic conditions brought about by the introduction, via the Uganda Railway, of elements which have turned the attentions of men into channels, not only other than religious, but even irreligious, and have created demands that are looked upon as development but do not really mean progress.

In the year 1886 there were two hundred baptized members of the Church of England in Uganda, and two adults were baptized that year. To-day there are more than sixty thousand baptized members, and six thousand baptisms take place annually.

Such numbers are almost appalling because of 


\section{The Danger of Numbers 199}

the responsibility of those in authority; they represent progress of a kind, but is it progress indicated by such vital godliness, high moral principle, general self-sacrifice and missionary effort as might be, and ought to be, expected from a young and healthy Christian Church still full of its first love? In my own mind I am convinced that it is not, and for some years I have endeavoured to study the cause or causes of such a condition of Christian declension.

In the first place, the very numerical success of Christianity has constituted one of its gravest dangers. It grew from beneath just as in the time of the apostles, but it gradually became the religion of the rich and powerful, with the result that the followers and dependents of the rulers thought it the right and honourable thing to seek baptism.

Every precaution was and is taken to test their mental, moral, and spiritual fitness, yet only those closely concerned know how impossible it is to say who ought or who ought not to be accepted.

The man who has not a Christian name and who cannot read and write is looked down on by his fellows ; consequently Christianity is the popular religion of the country, and is paying the price of all popularity in being too general, 


\section{Uganda to Mount Elgon}

weak, and shallow, rather than deep, strong, and lasting.

With God all things are possible, and we have no reason to doubt the value and deep reality of the three thousand added to the Church on the Day of Pentecost, but as a general rule large numbers are superficial; and in the Christian work in the kingdom of Uganda large numbers have been general.

I have already spoken of glorious work done; of the power of the Gospel message in the lives of many; so I cannot be misunderstood when I refer to facts on the other side, which every missionary deplores and endeavours to combat.

Secondly, it seems to me that although the Gospel had a good start in Uganda, making whoever really accepted it purer, happier, more unselfish and useful, yet it was working these wonders among a people more useless, selfish, weak, superficial, and cruel than any with whom we have been hitherto familiar. This being so it is foolish to expect that an ignorant people of naturally weak, shallow character and low standard of morality would not suffer from the sudden presentation by the Uganda Railway of Coast, Indian, and European civilisation.

They have suffered terribly, for the storm of 


\section{Mental Alertness}

temptation has been most severe; and one of the saddest features of the case is, that at the very moment when pastors and people need to be drawn very closely together, to understand each other, and learn to grapple with perhaps the one great crisis in the nation's religious history, the new ideas of housing have taken such a hold upon European and native, as to prevent their being thrown together as they were a few years ago, when privacy was at a discount and fellowship all important.

The alertness of the native mind, but also its superficiality, has made them jump at the concrete parts of the missionary's teaching upon the necessity for bettering their social condition; and they have to a large extent given themselves up to the questions of building, banking, sleeping, cooking, clothing, and eating to the exclusion of the development of moral principle.

Professedly Christian men openly speak about the infidelity of their professedly Christian wives, declaring that there is no such thing as faithfulness among the women of their country: we know there is much faithlessness amongst the men, and sleeping sickness is not the only scourge responsible for decimating the kingdom - the kingdom which at one time had a population of nearly two millions, but to-day is 


\section{Uganda to Mount Elgon}

little more than six hundred thousand, the population of Liverpool. Venereal disease is working sad havoc everywhere, so much so that a special commission has been appointed to deal with the matter.

It is not very difficult to get a wrong and exaggerated view of such a subject, and such it seems to me was presented to the United Services Medical Society, and reported in the Lancet of October, 1908.

In his paper Colonel Lamkin states that in some districts as many as 90 per cent. suffer from Specific Disease; and that it produces infant mortality to the extent of 50 or 60 per cent.

The first place in the cause of the epidemic is attributed to the interference by Christian teaching and teachers with the tribal laws and customs of the people.

On both these points the Drs. Cook, who know all there is to know about Uganda and its people, traverse the Colonel's paper; and show very conclusively that the ravages of the disease have not affected more than 19.4 per cent. in the most populous district; whilst on the second head they insist on the word civilisation rather than Christianity as the potent cause of the trouble.

It may not be out of place to emphasise here 


\section{Sir H. H. Johnston}

my strong belief in the power of the Gospel of Jesus Christ, not to ereate such licence as is responsible for the terrible evils mentioned above, but to guide and regulate the liberty, all too hastily given to the Baganda, into right and useful channels.

This emphasis cannot be better illustrated than by the words of Sir H. H. Johnston, who not long ago was Commissioner in Uganda :-

"If the Baganda are to be saved from dying out as a race-and I cannot but believe and hope they will-it will be entirely. through the introduction of Christianity and the teaching of the missionaries, both Roman and Anglican. The introduction of monogamy as a universally recognised principle now amongst all people who desire to conform to mission teaching may be the salvation of Uganda, strange to say. The people through this teaching are now becoming ashamed of marrying girls who have led a bad life before marriage. The appreciation of female chastity is distinctly rising, while at the same time young men find debauchery no longer fashionable, and endeavour to marry early and become the fathers of families. If ever a race needed a Puritan revival to save it from extinction it is the Baganda, and if ever Christian missions did positive and unqualified good among a negro race this good has been accom- 


\section{Uganda to Mount Elgon}

plished in Uganda, where their teaching has turned the current of the more intelligent people's thoughts towards the physical advantages of chastity" ("The Uganda Protectorate," p. 642).

Surely we have at once in this quotation any answer necessary to Colonel Lamkin's indictment of missionary work, and also the only hope for the future. God grant that the "Puritan revival" may not be long delayed!

I am also firmly convinced that the present stagnation in the religious life of the people of Uganda is connected with the tendency to sidetrack the Church and its agents along the line of secular education.

There is an insatiable desire for knowledge on the part of the Baganda, and they are people of undoubted intelligence, far more highly developed than that of the surrounding tribes; and I recognise the need for such education as will lead to the useful occupation of minds and bodies of such a people no longer given over to constant warfare. Up to a certain point the C.M.S. has given such education; for all its work in Uganda, whilst primarily evangelistic, has of necessity been educational of a very practical character; so much so, that not only has every candidate for baptism learned to read, but I dare 


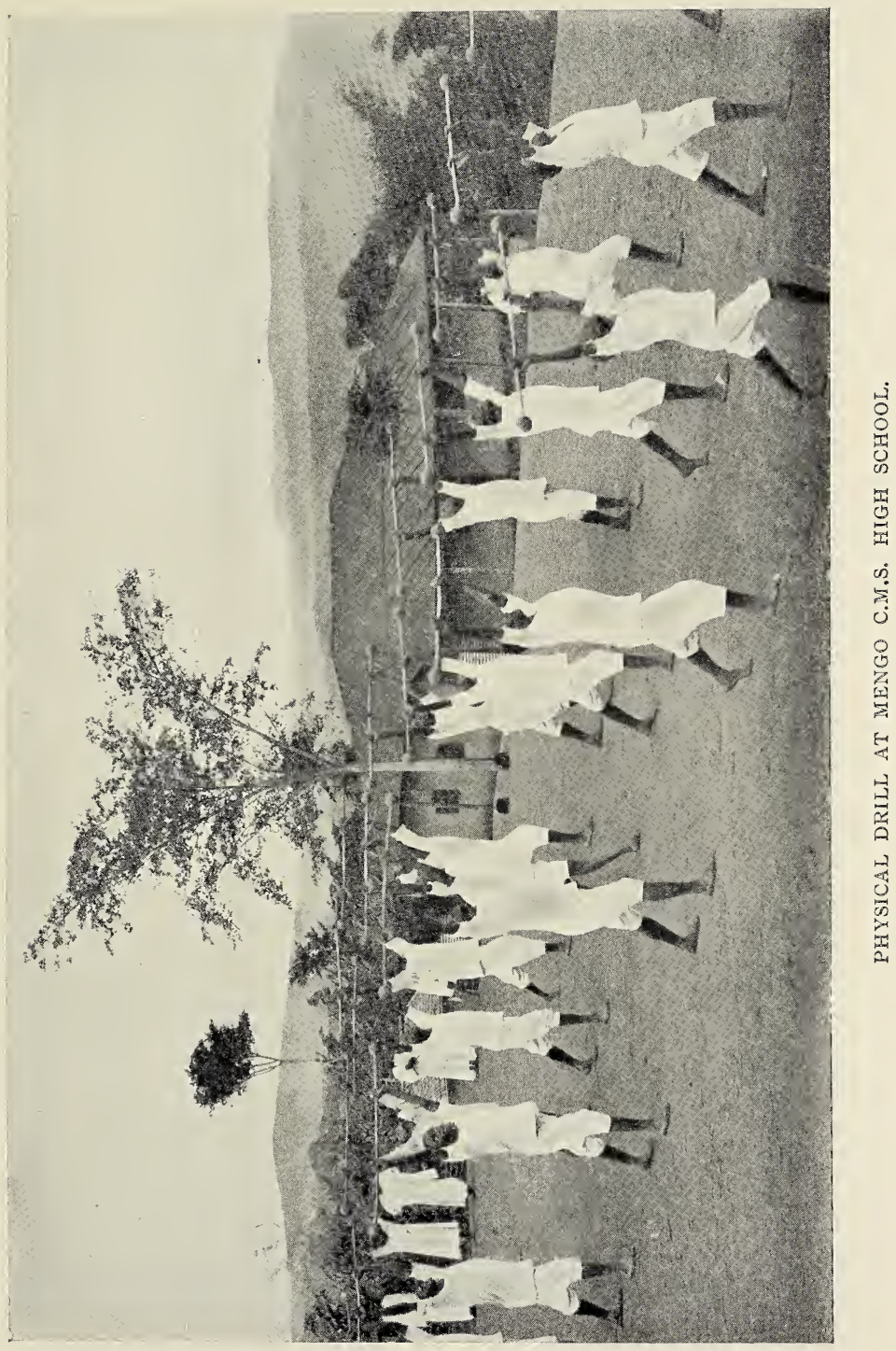





\section{Education and Evangelization 207}

to say that had there been no church on the hill there would have been no factory in the valley.

In its High School at Mengo it has also sought to meet on its own terms what seems to me any need for higher education; since its teaching is of such a character that, although it is carried on amongst youths who have been baptized, it is definitely evangelistic. From beginning to end it is an effort to remove young chiefs, and the sons of chiefs, from immoral surroundings, and to strengthen their mental and moral faculties through the influence of Gospel teaching.

The tendency of the times, however, is to demand from the missions educational work not primarily evangelistic, but such as will supply the requisite number of clerks, cooks, and carpenters.

There is no reason why missionary teachers should not be used to give such training to the Baganda if they or the Administration pay for it, and thus allow for the provision of other missionaries to do the work for which the Missionary Societies exist, and for which vast districts with far greater populations than Uganda are waiting. But there seems every reason why the C.M.S. should not give way to the popular cry, and set aside laity and clergy provided for out of funds gathered for 


\section{Uganda to Mount Elgon}

evangelistic purposes, to build up a general elementary education system throughout the country, or a higher educational system amongst youths already baptized, confirmed, and possessed of as practical, workaday an education as the average youth in England, and who may never give the Church's need one iota in return.

This latter system appears to be the trend and danger of one mission school recently begun in the country, and I sincerely trust that the idea will not grow; for the condition of Uganda is not analogous to that of India, where educational work is often the only means of reaching a large population with the principles of the Gospel.

The freedom of choice in their life's work offered to the students of such a school is undoubtedly ideal; but the payment of teachers ought not to fall upon missionary funds, i.e., upon those who have not as good educational advantages for their own boys, and who are really poorer than the Baganda whose teachers they are asked to pay.

The work of the Mengo High School, already referred to, if strengthened and developed so that all who wish to pay for the teaching, and the teacher, might send their sons and daughters (there are a number of poor lads being paid 


\section{Work of Church and State 209}

for by the native Church, chiefs, and friends at home-and this might be extended), and with a special department with higher teaching as preparation for definite missionary and ministerial work, is, with a theological college for teachers and clergy, all the education work the Church need trouble about. More than this will at present hamper missionary extension, and in time lead to difficulties such as are now threatening the Church at home, for history has a way of repeating itself.

Let it not be thought that I deprecate the value of true education; but $I$ do not wish the good to take the place of the best, and therefore say, let the State authorities take up at once their own responsibilities, and in the name of God's only-begotten Son, who has given us our marching orders, let the Church do its work of preaching the Gospel; for that, and that alone, was the cause of success in Uganda.

Another element of danger to the Church of Uganda, and reason for the present colour feeling, lukewarmness, and general down-grade tendency manifested by many Christians, is the supposed lack of sympathy and confidence shown towards them by their white teachers.

I need not emphasise the word supposed; 


\section{I $O$ Uganda to Mount Elgon}

that will be taken for granted by all who have come into touch with Uganda missionaries; but as in a former chapter I expressed my firm conviction that with very little British help the people of Uganda and surrounding kingdoms might be made to cheaply govern themselves, with results as good, if not better than those now forthcoming, so here I declare that I feel very strongly the time has come (if the opportunity has not already passed away) to give the native Christian of Uganda a good deal more say in the management of his own Church affairs.

Circumstances make the man, and since God has allowed the circumstances of marvellous missionary success, and the formation of a native Church, I cannot help but think He has, somewhere in Uganda, the native leaders necessary for such a Church if only they were allowed to lead.

The Church, like the Government, will suffer if the white man has a wrong idea as to the purpose of his presence in the country. Permanence, whilst the first thought with regard to his work, should be the very last thought in the missionary's mind with regard to himself, and woe betide the Church, goodbye to all native development, where the missionary, because of a mistaken idea of native ability 


\section{Native Responsibility}

or the danger of native responsibility, undue attachment to his own particular work, language limitation, or the circumstances of married family life, settles down to the "country rector" sort of life, where the work could be done as well if not better by a native pastor.

"Failure," says some one,-_" utter failure." Failure, yes, that is to be expected again and again, for by failure the Baganda will learn; but not "utter failure," for all the evidence goes to prove that where the Muganda has been trusted with responsibility, he has done extraordinarily well, but that where he has been a factotum to the white man he has been more or less a failure.

Happy the day for Uganda Christianity when the white men give all pastoral work into the hands of natives organised and directed for some years to come by an itinerant overpastor or archdeacon. Such a move would at once set free some experienced clergy and laymen to push out as pioneers to untouched countries, and would hasten the establishment of a self-supporting and self-governing Church, as well as kill the present native attitude of "Why need I worry, work, pay, or be present? -the white man is responsible for everything." These problems have long been in the mind 


\section{I 2 Uganda to Mount Elgon}

of Uganda's Bishop, Dr. Tucker, and he has striven incessantly for years to form a native Church with a constitution which places the native in such a position that he may one day become the head of his own branch of the Anglican Communion.

This constitution, accepted by native and European, is now in operation, and from it we may expect great things, since it seeks to develop independence, place responsibility upon the right shoulders, and make the Church selfsupporting and self-extending.

In the matter of self-support the Baganda have in the past nobly responded in order to meet every need; but I believe I am right in saying that at the present moment the financial condition of the Church is something worse than "from hand to mouth."

The innumerable calls for teachers, and the magnificent response, have been met by native funds; but the demands of the speedy growth and magnitude of the work have prevented those in authority from giving that attention to the organisation and development of the material side which the Church now requires. And at the very moment when we are thinking of religious independence for the Baganda, we are brought up somewhat sharply by the facts that the coffers are empty; with the 


\section{Hope for the Future}

exception of one in Toro, there is no permanent church building in the country; and the crisis of the nation and the Church is upon us through the mental, moral, social, and spiritual balance of the people having been upset by the too sudden presentation by the Uganda Railway of the material side of civilisation.

It will take some time to readjust their point of vision; and in the meantime, God grant that their attention may not be wholly taken up with cycles, watches, cutlery, clothing, houses, and Company shares!

A dull picture, probably: but I am wholly optimistic with regard to the power of the Gospel. I am also perfectly certain that the Christianity which withstood the persecutions of King Mwanga will live through the present critical stage of transition, and will emerge numerically smaller, no doubt, but brighter, stronger, and more real than ever before.

I have not yet seen Bishop Tucker's book recounting his past eighteen years' experience, but I have no doubt he there refers at length to the constitution of the Church in Uganda, so I need not speak further of it here. We are part of the English Church, so of course our services are the same; but I have often been asked about the nature of the elements used in 


\section{I 4 Uganda to Mount Elgon}

the celebration of the Holy Communion; and would explain that red wine is used in the cathedral church, and wherever else men have it; otherwise a native substitute is used. Personally I think this diversity of use a great pity, and wish the national drink of Uganda could be sanctioned; for as I do not believe that the efficacy of that blessed sacrament depends upon the time of its celebration, so I think it very unwise to convey to a nation's mind the idea that its efficacy depends upon the colour of the material in the cup, and so force them to begin an import which will not eventually be confined to Church use.

That the material itself is not the important factor may be argued from the diverse use in the English Church at home. In one Church there may be used an insipid mixture of coloured sugar and water, and in another a cheap poisonous port, neither of which ever saw a grape; so I cannot think that a universal use in the Church of Uganda of the unfermented native wine-a drink made from bananaswould be at all wrong or inexpedient.

"The best and purest Wheat Bread that conveniently may be gotten" is used at the capital and wherever else flour is procurable, and a person can bake it; but there are times when it is not procurable, and I cannot think 


\section{Church Uses and Discipline 2 I 5}

that under such circumstances the injunction "that all things be done to edifying" is more reasonably carried out by the use of a questionable biscuit than by the use of "such (food) as is usual to be eaten," viz., a baked plantain.

Is this not an occasion when, according to Article 34, "Tradition .. may be changed according to the diversities of countries, times, and men's manners"?

Another common question refers to discipline: "How do you deal with professing Christians who continue to live in flagrant sin ?"

At one time we dealt with them by exhortation and expostulation, and when these failed they were excommunicated. But now such a thing is almost impossible, owing to the fact that we have no working agreement with the Roman Catholics, who will receive those who go over from the Anglican Church. In my first district there was a chief who had led a clean and good life until he was baptized into our branch of the Church. Then he began to go back, and became, what he had probably been before preparing for baptism, one of the biggest rascals it has ever been my lot to meet. I did my best to help him, and got kindly natives to deal with him, but all to no purpose; 


\section{I 6 Uganda to Mount Elgon}

so I warned him that there was nothing left but excommunication. His case was to come before the Central Church Council at Mengo on a certain Saturday, and he left his country place a day or two before to go up to the capital. On the day when he ought to have appeared before the Church Council to show reason why he should not be publicly excommunicated he was parading the capital laden with rosaries, medallions, and crucifixes, declaring that he had found a better religion than ours, having become a Mufalasa, i.e., a Frenchman. Although leading a wretchedly bad life, he had been received into the Roman Catholic Church-a thing which could not have happened had there been a working agreement between us to deal with such cases.

The feeling that we should be driving them to the other side, and probably the fear to lose some of those in authority, is responsible to some extent for the general weakening of Church authority consequent upon the disuse of excommunication.

The present Bishop of Uganda, with the assistance of men like Gordon, Walker, Pilkington, Baskerville, and others, has done a glorious work, which is now at the parting of the ways; and much depends upon the Church's rulers as to what the future will be. 


\section{Need for a New Diocese 2 I 7}

The size of the diocese is detrimental to real progress, for it is impossible to give it adequate supervision, and to keep in close touch with and supply the varying needs which require unwavering continuity of purpose.

An Executive Committee does not meet the need, for it is no part of the native Church; and members, because of the pressing needs of their own districts, or because they are totally ignorant of the needs and exigences of work in other parts, are not always able to give that adequate consideration necessary to develop a work which requires chiefly tenacious continuity of purpose.

The Bishop, as head of the Church, is the one to give close attention to the development of its constitution, with its ideas of self-government, self-support, extension, \&c., and if the present or future Bishop of Uganda is to do this, his work must be considerably minimised by division and the formation of another diocese between Uganda and Mombasa.

The new diocese should extend from Nassa to Abyssinia, and from Usoga to the Kikuya Escarpment, and would contain more than six millions of inhabitants whose language and mode of living mark them off very definitely from the peoples of Uganda, Usoga, Unyoro, and Toro. 


\section{8 Uganda to Mount Elgon}

Mount Elgon district would be the very centre of such a diocese; therefore strengthen and develop the work at that centre-a distributing base convenient in every way. 


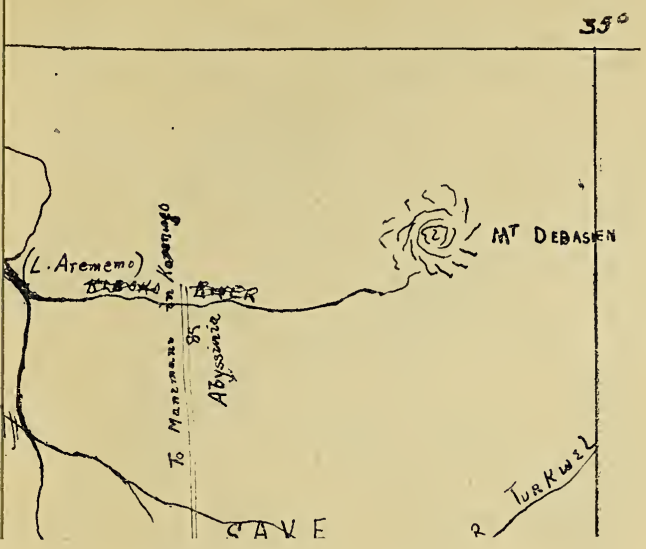





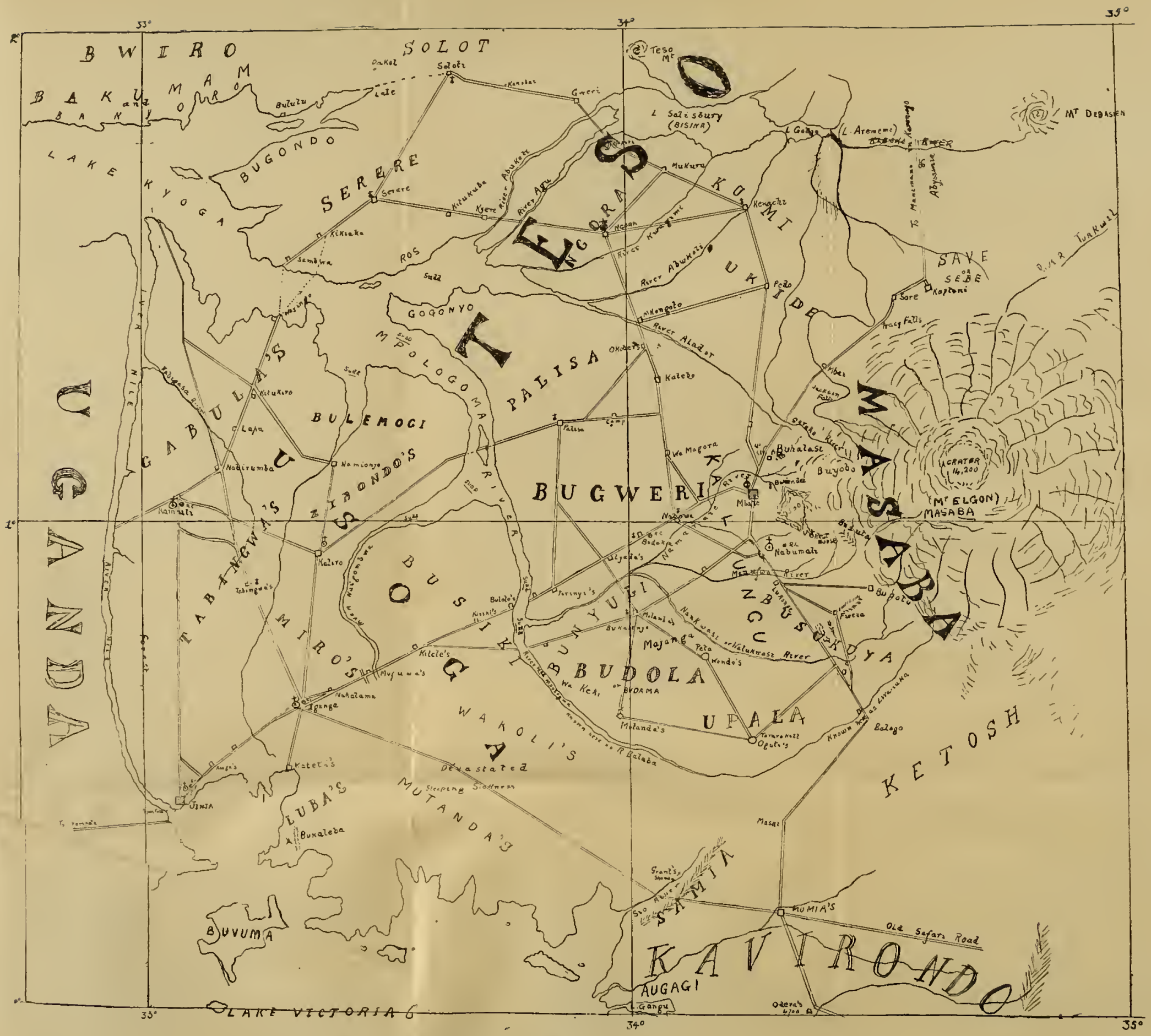

ROUGH MAP OF USOGA AND ELGON DISTRICTS SHOWING THE OPENING UP OF THE CENTRAL PROVINCE.

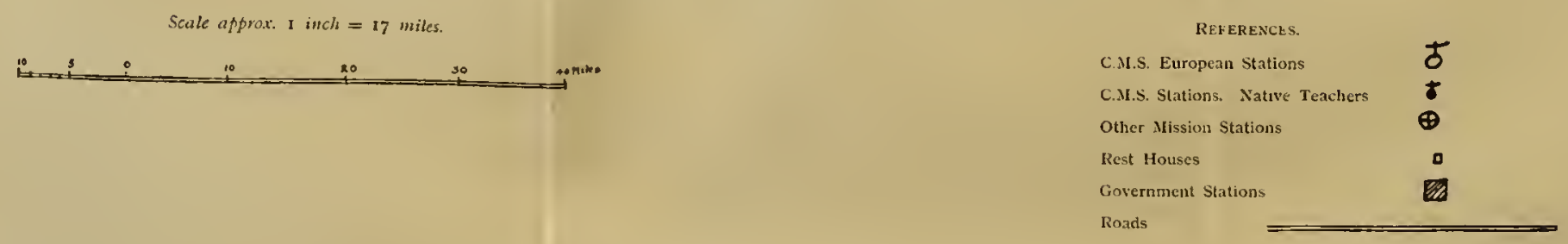



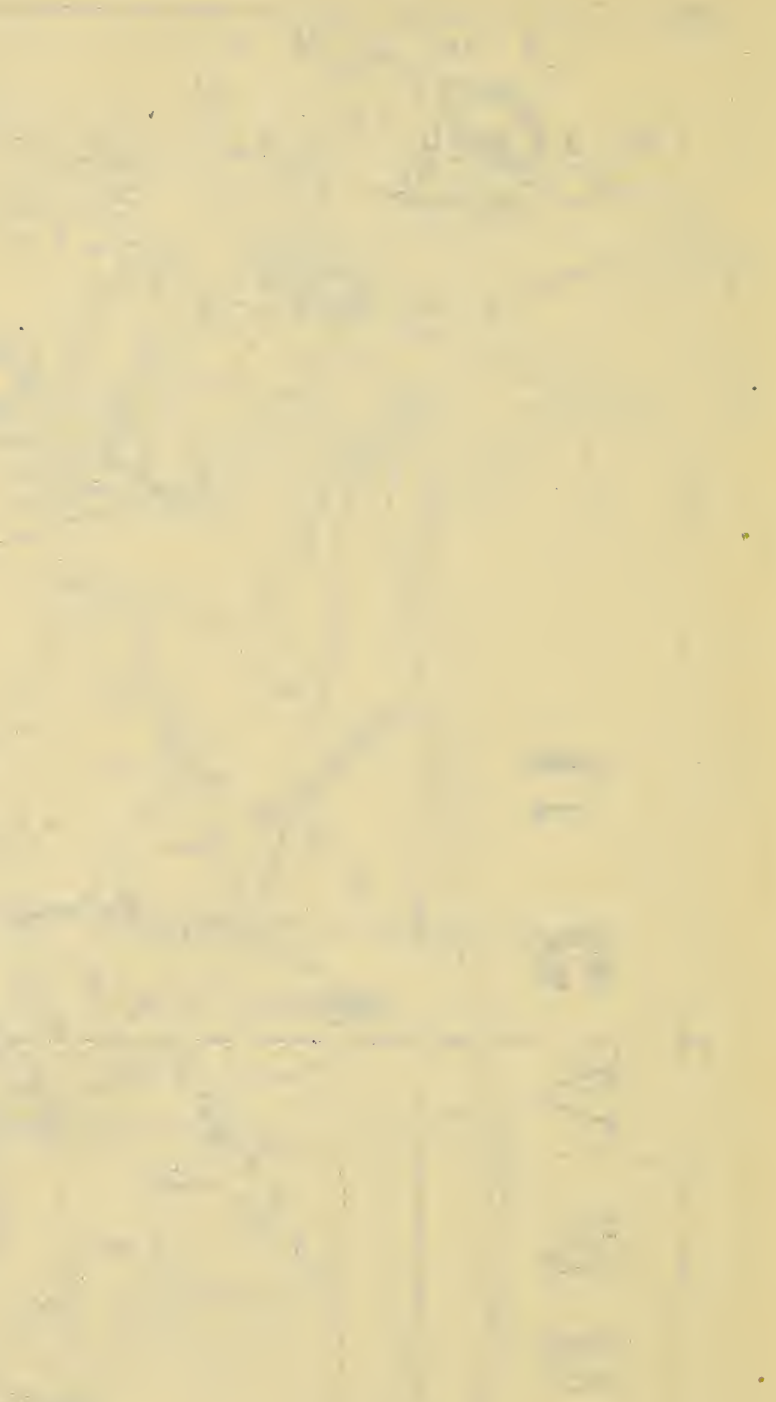


\section{CHAPTER XI}

\section{THROUGH USOGA}

A journey eastward-Kyagwe-Ham Mukasa-A visit to England-Samwili Kangawo-Perfect gentleman-Wayside camps-A view of Lake Victoria and Usoga-Ripon Falls-Whence the Nile springs-A dangerous ferryA unique welcome-Jinja and its possibilities-From Lake Victoria to Egypt-Agriculture-Road-making-A good centre-Clever thieves-Slow work-Christian revengeFamine-Hut-tax returns-Value of a paramount chief.

UR journey must be continued; and having seen what there is to see in Uganda, and having ascertained that Masaba is a country situate on the slopes of the extinct volcano, Mount Elgon, our next businesss was to get there.

It might have been reached direct from Port Florence, the terminus of the Uganda Railway, by marching north through the part of Kavirondo occupied by Nilotic people, and on through the Bantu people at Mumia's. This journey in itself would be a revelation and 


\section{Uganda to Mount Elgon}

education to many; but having crossed the Lake Victoria, I prefer to take you from Namirembi, directly east, viâ the birthplace of the river Nile, through the country of Bishop Hannington's martyrdom, the scene of sleeping-sickness ravages, and on into regions until this last year or two unknown.

After waiting for loads long delayed on the railway, then again for porters to carry them, we set off through Kyagwe, the eastern district of Uganda, a most beautiful country with the road running through well-tended banana gardens and ideal tropical forests.

The native head of this district is Ham Mukasa, the intelligent Muganda who accompanied the Katikiro, or Prime Minister, to England for the Coronation of King Edward. No traveller to Uganda should miss the opportunity of coming into touch with this chief, or his friend Samwili (Samuel) Kangawo, chief of the district Bulemezi, north of Mengo. $\mathrm{He}$ will be astonished to find such intelligence, strong character, perfect gentlemanliness, real goodness, and deep religious feeling, without a suspicion of cant. He will also learn, on passing through Kyagwe, that its chief is practical in his administration, stern in the suppression of lawlessness, and just yet merciful to offenders. 


\section{A Native Gentleman}

As we approach his place we are met by runners who give us their chief's greetings, and soon we meet the gentleman himself; for he has ridden out some distance on his cycle to welcome us, and, with his retinue, he escorts us to his house for rest and refreshment.

English chairs, or chairs made in Uganda from an English pattern, are provided for the guests, and tea is served in proper style, during which the wife and child of our host are presented to us, and crowds of natives assemble to do honour to their chief's guests.

Kindness, tact, and courtesy seem characteristic of this man, and as an illustration let me say how well I remember his staying in my camp until very late at night in order to help mend a bicycle that had met with an accident on the way.

Our pleasant visit to this chief was all too short; we found him interested in the spiritual and social welfare of his people, keenly anxious to help the poorest person in his district, and not forgetful of the welfare of his guests and their porters. Messengers were sent off in front of us, to warn the people along the road of our approach, and requesting them to provide food for the porters, for which they would be paid. 


\section{Uganda to Mount Elgon}

We had three days' march after leaving Ham Mukasa before we reached the Nile; and twice we slept in the camping-places prepared for the use of travellers. As a rule these places are fenced off in order to provide some protection against thieves and wild beasts. There is a place for the European's tent to be pitched, a rest-house for his men, and sometimes a little thatched place in which the traveller may sit during the heat of the dayan undoubted boon, but, owing to the prevalence of the tick, responsible for conveying Spirillum fever, they have become veritable death-traps.

Pushing on still eastward, we reach Nyenga, and get an exquisite glimpse of Lake Victoria, backed by thickly wooded Usoga. From here it is a rapid descent to the lakeside and more particularly to the interesting spot where the water dashes over the Ripon Falls to form the Nile.

Undoubtedly the traveller will be somewhat disappointed if he expects to see the water falling from a great height, but he will not be disappointed in the amount rushing over. The prettiness of the scene immediately near the Falls has been recently considerably modified; for the dread scourge of sleeping sickness has made it imperative to cut down all trees 


\section{A Dangerous Ferry}

and bushes that lined the banks of the stream.

In the pool above the Falls crocodiles and hippopotami abound, and since these are a menace to the users of the public ferry between Uganda and Usoga, it is allowable to shoot them without having procured a licence. No doubt the powers that be realised that the ferry, crossing as it did, until quite recently, very near to the Falls and without any protection in bad weather, and carried on by means of the laced native canoe from which the keel-board has been known to fall when crossing, was danger enough to the traveller. Perhaps the time is not very far distant when not only will the crocs and hippos be cleared from Napoleon Gulf, but a small oil launch will run from shore to shore; and even now the spicy feeling of possibly drifting over the Falls might be taken away by drawing a wire cable from Uganda to Usoga.

We must deal, however, with things as they are, and sit down on the Lake shore until a few canoes have been collected together. With gentle persuasion and much force the mule is pushed and lifted into one, a milch cow into another, the loads into another, and ourselves into a fourth. The native porters, firmly believing they will be safer with a 


\section{Uganda to Mount Elgon}

European, make a rush for our boat, with the result that we are all but swamped, and another half-hour is wasted in adjusting, shouting, and threatening before we can leave the shore of Uganda.

One notable crossing I made recently at this ferry was with the Rt. Rev. Dr. Tucker, Bishop of Uganda, who was leaving Uganda to visit the vast regions forming the eastern portion of his diocese. He was expected at Jinja to confirm the many candidates, young and old, who had been prepared by the Rev. T. R. Buckley, B.A. L.L.B., now Archdeacon of Usoga; and remembering how short a time it is since Bishop Hannington was murdered in this very district, the reception accorded to his successor seemed nothing short of wonderful. As our canoes approached the shore of Usoga, we could see Buckley with his school lads, the sons of chiefs, and practically all the chiefs of the country waiting to welcome their Bishop (even the old man Luba, who had killed Hannington, though dying, was represented), and with the others helped to send up a good imitation of a British "Hip, hip, hurrah!" when the Bishop stepped out of his canoe.

It seemed hardly credible that this could be the country of Usoga, and these its people. 


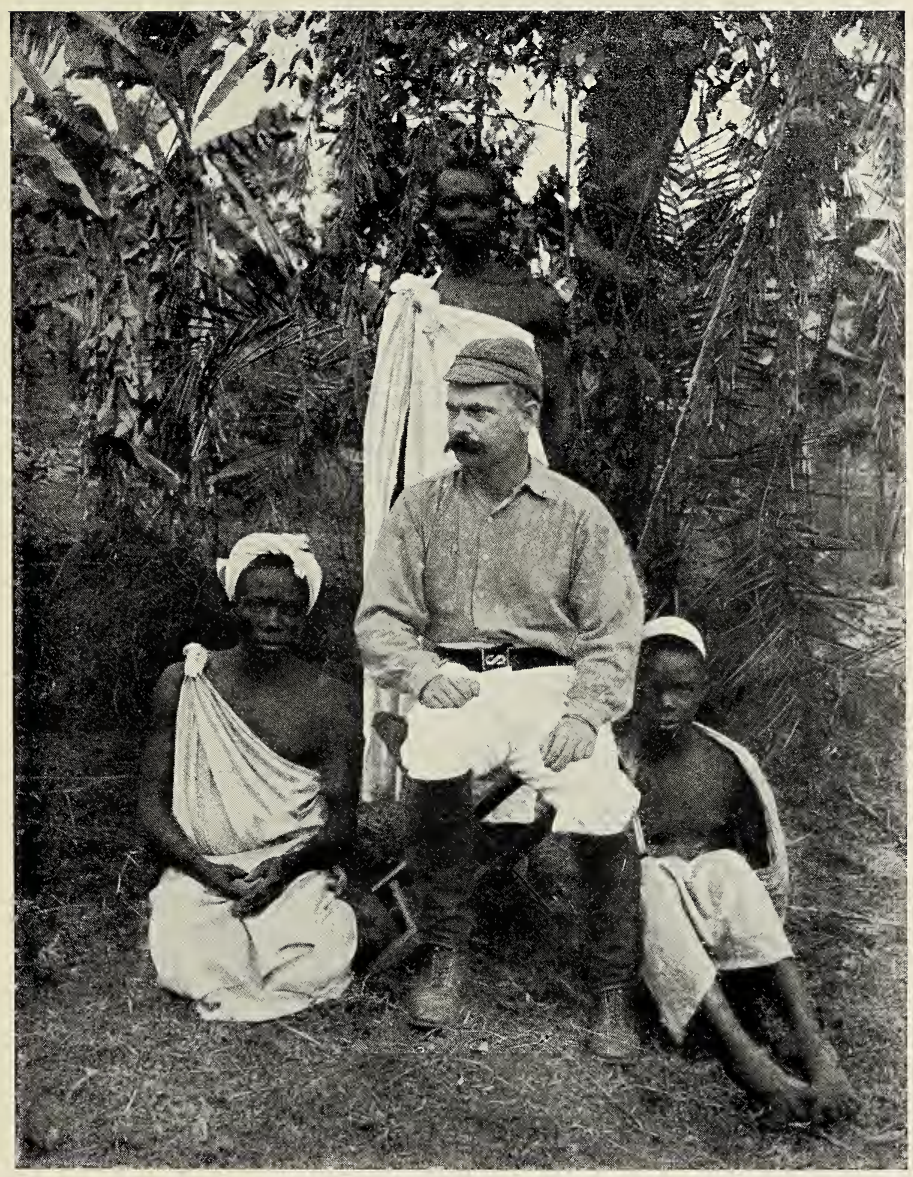

THE VENERABLE T. R. BUCKLEY, B.A., LL.B. 



\section{Good Work and Workers 23 I}

Only a short time ago it was subject to the tyrannical rule of Uganda, whose meanest peasant despised the Usoga people, and looked upon them as lawful game, yet here were men and women escorting us from the ferry to the Mission station, whose faces had quite lost the crafty, hunted, and fearful look so often seen on the downtrodden African; whilst in its place could be detected calm strength and dignity, thanks to the work of such Government officers as the two Grants, Boyle, and Cubitt, and missionaries like Buckley, Wilson, and Skeens. "The persevering, patient, quiet life of Buckley, living there among the natives in his $£ 30$ mud-house, has done more for us fellows and for the country than any outsider can ever know," said a Government officer to me; and to see the native chiefs around him, and their attitude to each other on that day of the Bishop's arrival, enabled me to understand what the officer meant.

As we looked from chief to chief we soon realised that the sleeping sickness had been no respecter of persons; this one and that one well known to us had passed away, and vast districts through which the Bishop and I had travelled years before, and found teeming with population, are now as howling wildernesses. 


\section{Uganda to Mount Elgon}

Jinja is an important place, and likely to become more so, for it is the Government headquarters for the Central Province of the Uganda Protectorate. It is healthily and beautifully situated, overlooking the Ripon Falls and the Napoleon Gulf. The Uganda Railway has recently completed a very good pier, along the side of which the Lake steamers are berthed when they call each week to take off the large exports of ivory, hides, skins, ground nuts, and pepper.

There is very little doubt but that soon we shall have here a large power station, certainly to supply all local needs, and, let us hope, to be used to open out the countries lying east between Jinja and Kisumu.

It is now possible to travel from Jinja down the Nile to Unyoro and on to Egypt. This route was followed by the Right Hon. Winston Churchill on his recent tour through East Africa and Uganda. The Government propose to run a railway from Jinja to Kakindu, a place on the Nile about forty miles north, where a small steamer will meet passengers and take them on through Lake Kyoga to Unyoro. A survey party has also actually started to map out a line from the Nile through Masindi in Unyoro to Butiaba on Lake Albert Edward, thus bringing Jinja 
into direct communication with the Congo Free State.

Usoga has a far richer soil than Uganda, and even now the natives are experimenting with cotton-growing; but unfortunately there is no one to buy it from them after it is grown. Perhaps soon we shall see gins and baling presses here at Jinja, with such waterpower at hand, and the steamer only a few yards off ready to receive shipments for Europe.

A beginning has been made with rubber-tree planting, but already two planters have died from blackwater fever; and men taking up such work should never live and work alone, for by working in pairs it might be possible to arrange for change and rest when necessary, instead of having to succumb as much to worry and work as to fever.

The position of Jinja will always prevent its becoming a great native centre on account of the food difficulty; and since we must leave, let us push on eastward to Iganga, the natural capital of the country, where once there was a Government Boma and where again, I have little doubt, will be set up the headquarters of native administration. Iganga is only eight miles from the Lake; it is very central, thickly populated, has a good food supply, and from it native-made roads running in all directions. 


\section{Uganda to Mount Elgon}

Nowhere in the Uganda Protectorate has there been a greater waste of native labour than on the road running east from Jinja through Iganga. A necessary waste, maybe, under the circumstances, but a waste nevertheless, and it must be gratifying to native and European to know that the Government intend to spend $£ 2,000$ this year on a properly made road.

Unfortunately, the sleeping sickness seems specially busy in this centre, and the Government has recently opened a camp for patients. The C.M.S. agents have done a good deal of work amongst the sufferers, but since little relief and no cure is possible the work is specially difficult.

The C.M.S. has had a station here for some years, and a wonderful work has been done among a people despised by the Baganda and notorious for many evil practices.

The Baganda are clever thieves, but are not to be compared with the Basoga.

Some years ago, before the Uganda Railway was built, when about to travel down country I had occasion to encamp for some days in Usoga for the purpose of buying food for my porters. I knew the people were given to stealing, for they had actually taken the rifles from some of the Indian soldiers who were 


\section{Clever Thieves}

sent up to Uganda after the Soudanese rebellion, but as there was nothing of great value in my camp I hoped we should be unmolested.

All went well until the food supply was complete and preparations made for an early start. Each porter retired to rest with his bag of meal under his head, but before morning every vestige of food had been taken and my tent rifled. I begged the men not to make an outcry, but to rest until the morning and then go on with the packing and preparation for the march as if nothing had happened. I was busy at breakfast when a princess and acting chief appeared and commiserated me on my losses; I was sure the ruse was working and that we had found the thieves, for how otherwise could they know of the matter? And you can imagine their consternation when, instead of allowing them to leave my camp immediately after condoling with me, I declared my intention of taking them on to the nearest Government officer. For very shame they dared not bring back the meal and cloth stolen, but they immediately offered to pay the value in goats and sheep.

This thieving trait in the character of the Basoga has been developed under proper teachers organised by the chiefs, and I am 


\section{Uganda to Mount Elgon}

thankful to say it is dying out under the stern measures of the Government and the influence of Christian Missions.

Iganga has always been a trying station, and the Europeans have suffered a good deal from thieves, wild animals, and disease. The Mission ladies have often had attempts made to enter their house at night-time; leopards repeatedly walk across their courtyard, and not long ago, whilst I was there, a sleeping-sickness patient was carried off by a hyæna or leopard from a hut within the compound. On another visit I found one of the ladies who had been waiting upon this very patient down with blackwater fever, to which she succumbed after only a few days' illness.

Slow, dull, and trying for missionary and administrator this work in Usoga; but already the reward is wonderfully encouraging. Thousands under instruction, many showing evidence of mental ability that will compare favourably with that of the average boy or girl in England. A large number of capable native teachers, a number of promising candidates for the ministry and young chiefs who would have sunk only too readily into the slough of their forefathers are being mentally, morally, and physically prepared for the task of ruling their districts in accordance not only with England's laws, but 


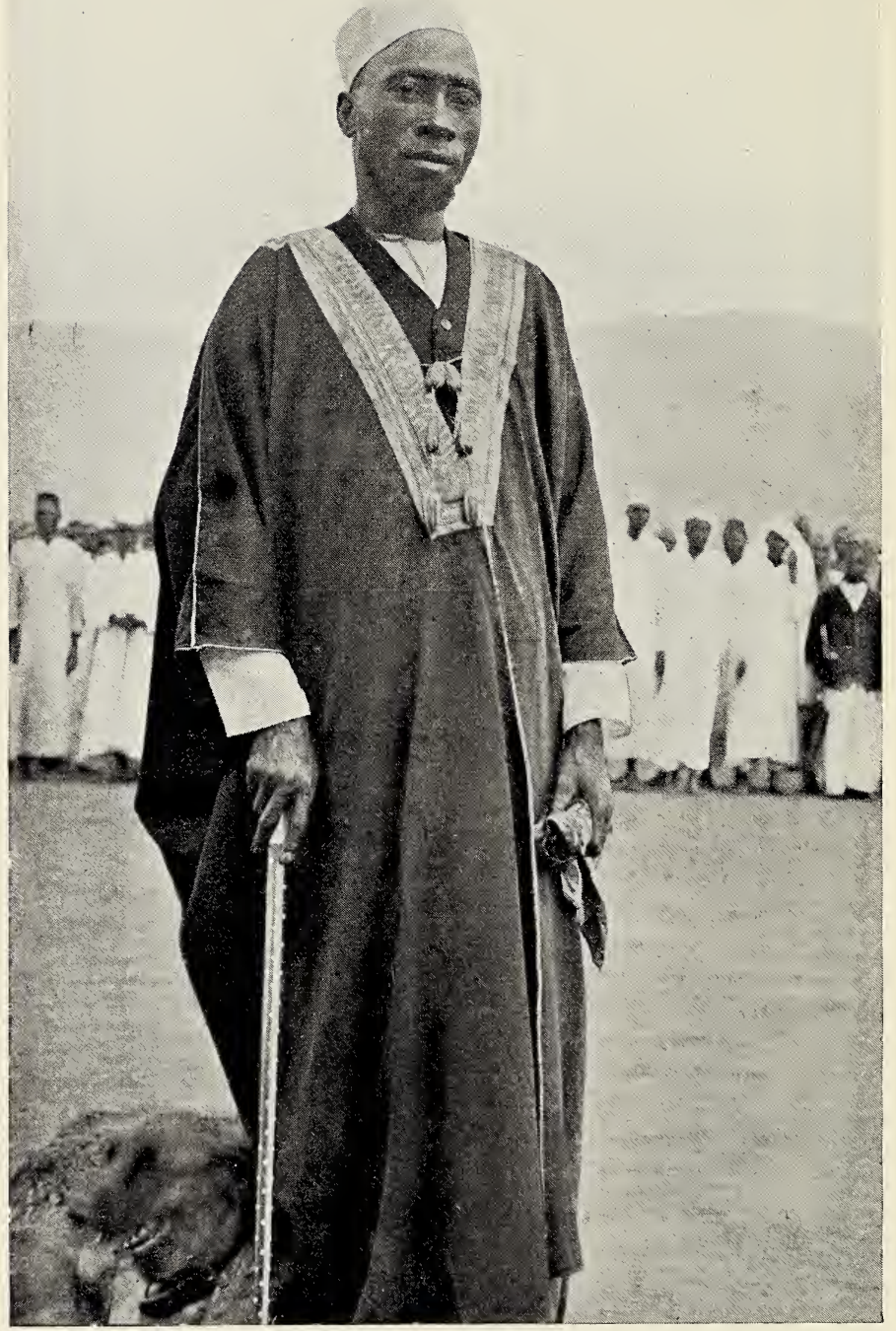

SEMEI KAKUNGULU. 


\section{A Noble Revenge}

also that authority responsible for England's greatness-the Word of God.

Such is the revenge of the C.M.S. and Christian England on Usoga for the murder of Bishop Hannington; and this revenge must have appealed to the most. bigoted heathen when, as a climax, the son of the murdered Bishop baptized the son of the murderer "into the name of the Father and of the Son and of the Holy Ghost."

Even as I write, the news has reached England that Usoga has been visited by a famine and some thousands of people have died in spite of the efforts of Government officers and missionaries. Such a condition of things will continue, I presume, until the resources of the country are so organised that every nerve is not stretched to secure big hut-tax returns, but to teach the people that they need not succumb at the first prolonged drought.

It is interesting, too, to note that although Usoga is sometimes held up as an example of what can be done in the way of hut-tax returns without any definite payment to chiefs, such as we have seen prevails in Uganda, it has been found necessary to take a capable and influential Muganda chief-Semei Kakungulu - and set him as president over the other chiefs, to develop in the minds of the Basoga the more advanced, yet 


\section{Uganda to Mount Elgon}

ancient, methods of the Baganda, based on the feudal system.

It would be infinitely cheaper, quite as efficient, and undoubtedly practicable, were Semei Kakungulu made absolute paramount chief of the Central Province and an Administration set up in accordance with the idea already proposed for Uganda and neighbouring kingdoms-i.e., Semei Kakungulu and the native chiefs, under the direction of a capable white adviser, would do the work of the present junior officials. 


\section{CHAP'TER XII}

\section{ON THE MARCH IN UNKNOWN LANDS}

Bukedi-River Mpologoma-Dug-out canoes-Papyrus-Disenchantment-Strange dwelling-places-Lake KyogaFloating islands-A spicy experience-Teso countryClothing despised-Remarkable village fences-Curious ornaments-The care of children-Precautions for benefit of girls-Fear of a mother-in-law-Mission work-Lake Salisbury-A primitive race-Turkana people-Hair-dressing and use of pillows.

T NTIL quite recently Usoga was the limit of the Baganda marauding expeditions, and beyond that the vast countries stretching away to Lake Rudolph and Abyssinia were all denominated by the one word Bukedi, a word corrupted by the Baganda from Ukidi, the name of a district in the Teso country, and conveying to the Baganda mind a great land inhabited by dangerous, naked savages.

I have journeyed into these countries from rail-head at Kisumu, from our last resting- 


\section{Uganda to Mount Elgon}

place, Iganga, going directly east, and also from Iganga, going north viâ Kamuli on to Lake Kyoga, and thence in canoe to Bukedi, or, more explicitly, Teso.

Let us now march directly east, my wife having taken her place in the hammock I made to help her along.

In three marches from Iganga we are at the side of a great expanse of water which the natives at this point call Mpologoma, or Lion. This water has been described as a backwash of the Nile, and it has also been mapped as a swamp, but after careful observation I have been able to map it as a river, and one of the chief rivers to carry off the waters from Mount Elgon to Lake Kyoga and thence to the Nile.

Former travellers may well have supposed the River Mpologoma a swamp or lake, for where it is touched in Usoga by the ordinary trade route it is one mass of papyrus, through which the natives have cut a passage for their dug-out canoes.

This passage has recently been declared a Government ferry, which means, I suppose, that the natives will still have to provide the means of transit and pay for the privilege of doing so.

It is a source of amazement to stand at the river-side in the early morning before the sun 


\section{The River Mpologoma 243}

has looked over Mount Elgon, when a silence which can be felt reigns supreme, to hear your cries for boatmen come back to you with a hopelessness that suggests death and desolation, and then to see a weird figure standing erect on a small piece of wood, across which the water pours, shoot out from the highgrowing papyrus, paddle himself swiftly to within a few yards of you to comfort you with the assurance that large canoes will soon be on the spot.

The meaning of the word soon is undoubtedly relative, for to the African it may mean two hours, a day, or even longer; still, since "all things come to him who waits," even the giant dug-out canoes on the river Mpologoma appear, brought from their hiding-places in the papyrus by numbers of men and women who have sprung from no one knows where.

Every one seems to talk at the same time, and there is a babel of language, for there are porters from Masaba, Uganda, and Usoga, whilst the boat people speak a dialect quite their own. Each one knows better than the other how to induce a mule to enter a canoe, and the result is chaos with good promise of disaster; but at last every thing and being has found boat-room, and some of the canoes have already disappeared down what looks a long 


\section{Uganda to Mount Elgon}

lane, but is really the ferry cut by the natives through the papyrus from bank to bank of the river.

The traveller has no doubt settled himself to utilise the forty minutes crossing by thinking of the wonders of Africa and wonderful ways of the African. He has been intensely interested in the canoes, the men and women, some of the latter with babies hanging on to them as they paddle and chant their way across the stream; and he has also been interested in the way the men jeopardised their lives in fighting for a place in the canoes. How true these porters are to their charge! And he begins with admiration to study the faces of the men in his canoe.

He is encouraged in his study by a smile which greets him from the end of the boat; but that same smile quickens him into mental and physical activity more effectually than the myriad mosquitoes that have left their restingplaces in the papyrus to claim blood-relationship with the new white man, for by a lightning process of deduction he concludes that since that smile belongs to the mule-boy then the mule has been sent on alone to be pulled and mauled, and perhaps lamed, on the opposite bank by the men who do not understand it.

$\mathrm{He}$ looks round and recognises men who 


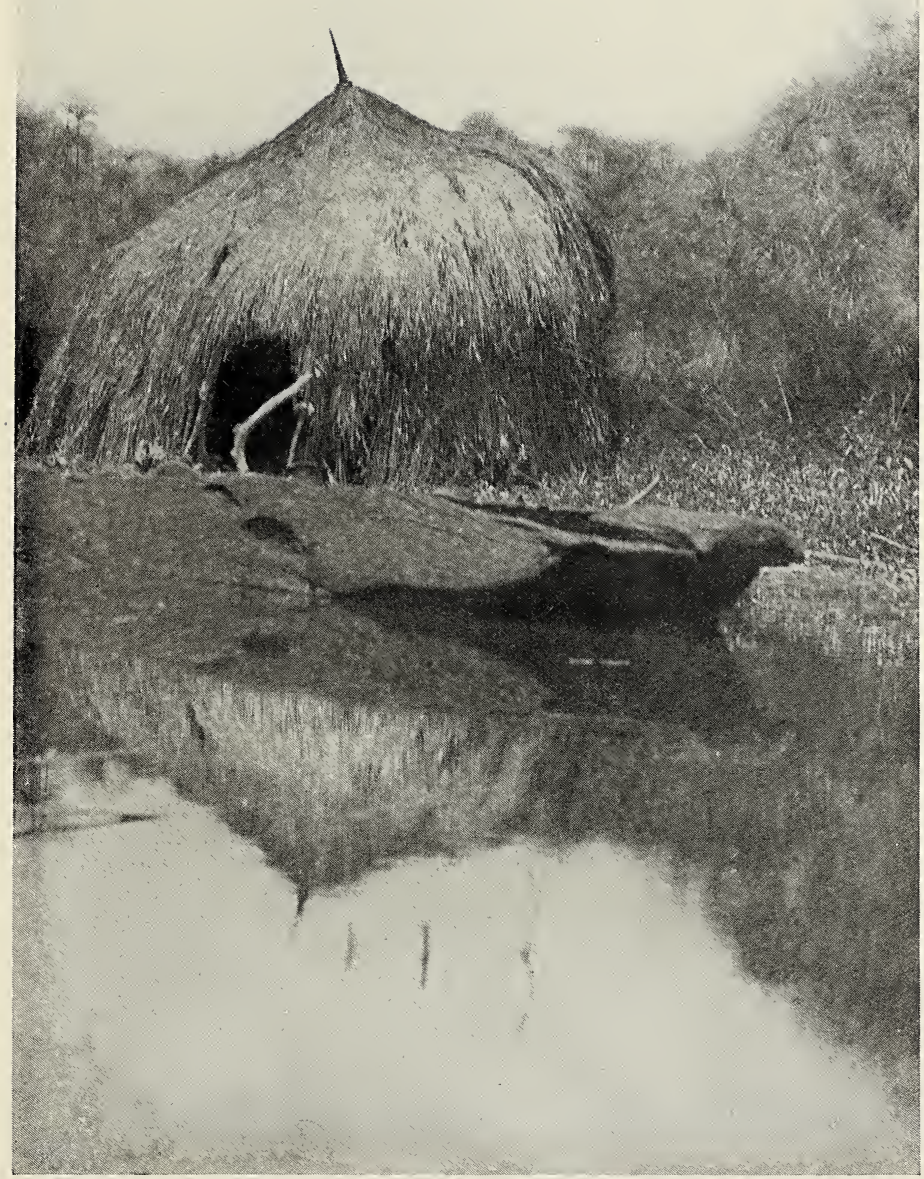

HOUSE BUILT ON THE RIVER MPOLOGOMA. 



\section{Weird and Wonderful Houses 247}

ought to be with their loads in other boats, and fails to recognise the men who so carefully deposited loads that as far as possible always travel with the European. The loads indeed are near, but will have to wait half an hour on the bank-side before the porters told off to carry them arrive.

The traveller soon realises, if he has not already done so, the philosophy of the Kiswahili "Pole, pole" ("Slowly, slowly"); and of the Luganda proverb, "Akwata mpola atuka wala" ("He who goes slowly reaches far"); and having comforted himself with the thought that he will arrive some time, he settles down-as well as the mosquitoes will allow him-to pass the time profitably.

This at any rate was my experience; and having heard a rumour to the effect that the people lived in the papyrus, I got the rowers to take me out of the usual route to see the chief of these men and women of the river.

The canoe was made to wind in and out among the high-growing reeds; and then with a sudden push through what seemed an impossible barrier, we were amazed and delighted to find ourselves floating in a clear expanse of water, at the far side of which stood, as if also resting on it, a large-sized, comfortablelooking native house, out of which a dog came 


\section{Uganda to Mount Elgon}

to bark at us, whilst the children, affrighted at the sudden appearance of a white man, stood at a safe distance within the doorway and gaped.

No island or mud-bank near, it seemed inconceivable that any house could be in the vicinity; yet here was one, and I afterwards found many more.

The natives explained to me that in years gone by there was no security in the countries bordering this great river. Their forefathers were constantly raided, and were eventually forced to seek shelter in the marshes and rivers.

Some ingenious man found that by cutting the papyrus level with the water, and then sewing the stems together, he was able to make a substantial and safe surface upon which it was possible to build a house safe from the land robbers, and from which terms could be dictated to those who wished to cross from one side of the river to the other.

Quite a strong community of these river dwellers is to be found on the Mpologoma; and whilst it is marvellous how they have withstood the mosquito pest, it is most pitiful to know that the sleeping-sickness fly has reached their dwelling-place, and most of them are probably doomed to die of this awful plague. 


\section{Lake Kyoga}

It was a pleasure to go in and out among these people whenever I was at the Mpologoma; and through the kindness of a Muganda chief I had a little church erected near the river to which some of them came to read, hear, and learn of the love and peace of God.

The river is known by different names in different parts of the country, but I have carefully traced it from Mount Elgon, and have given it on the map on pp. 220-221.

Having crossed it on the road running directly east from the Nile and Iganga, we have a journey of some forty miles to travel before coming to our Masaba Mission station situate on the foothills of Mount Elgon; and since the intervening country is somewhat uninteresting it will not be amiss to retrace our steps and take the reader north from Iganga across Lake Kyoga, formed no doubt to a great extent by the river Mpologoma; at any rate fed by the Nile, Mpologoma, and connections from Lake Salisbury, which acts as a reservoir for much water from Mounts Elgon, Dabasian (Kokolyo), and Teso.

It seems to me that when dealing with the Nile supply too little notice has hitherto been taken of the water pouring into Kyoga from these mountains.

Great floating islands of papyrus are a 


\section{Uganda to Mount Elgon}

feature of Lake Kyoga, for the rush of the rivers Mpologoma, Naigombwa, Abuketi, and Agu seems to prevent any thick growth in the water, which is here quite expansive.

The crossing is quite a spicy experience, especially when the headman of the canoes, in order to extract a compliment, informs one that the canoe in which we are sitting turned turtle on the journey from the other side, and was only saved by the skill with which he and his fellows got it and themselves alongside a floating island.

In fear and trembling our porters land on the shores of Bukedi, as they call it, but really in Serere, a district of Teso, a large country stretching from Lake Kyoga to Lake Rudolph, and occupied by a Nilotic tribe of people.

We are, indeed, in a strange land: houses, people, language, cultivation, all differ from anything met with elsewhere in the Uganda Protectorate, south of Acholi country, and even the white man can sympathise with the nervousness of his porters.

Remarkably tall men absolutely naked, and women with bead and iron belts from which hangs a fringe behind and in front go stalking past; and large companies can be seen at work preparing the ground for the sowing of millet, the chief item of food. So there are 


\section{Teso Country and People $25 \mathrm{I}$}

certain evidences of a large population, but not a house can be seen until some friendly native escorts us behind the thick screens and defences formed by the cactus plant, and there in peace, safety, and comfort is seen the patriarchal family with all they require.

As an additional defence the doorways of the houses are often made so remarkably low that people and cattle are obliged to kneel to enter. This custom has developed a condition of chronic white swelling, or housemaid's knee, among many of the men, women, and cattle; and it is a most peculiar sight to see people and cattle walking about with a great swelling on each knee.

Polygamy is the usual custom of the people in these regions, and the favourite wife can generally be distinguished by some special mark of favour. In one group I photographed the chief's favourite was wearing an iron chain apron, and was looked upon as a great swell.

The rest of the ladies in the group had vied with each other as to how many rings they could wear in nose, ears, lips, and tongue, and one young girl seemed very proud of the fact that she had five rings in her tongue, which she shyly kept out whilst I was taking the photograph.

The men are equally fond of such adornments 


\section{Uganda to Mount Elgon}

to ears, nose, and lips ; and further north they enhance their "beauty" by allowing their hair to grow, and then working into it thick potter's clay, which looks and feels almost like an unnatural growth. Into this clay they stick ostrich feathers, which add considerably to their already great height and striking appearance.

Nowhere else in Africa have I seen the care bestowed upon infants which is to be met with in Teso country; and one picture explains what I mean. The tall mother has been on a journey, and her infant is resting in a very nicely made skin sling on her back. To protect the child's head from the sun a gourd has been prepared, and can be seen in the picture hanging from the mother's neck and covering the baby's head.

The pictures of a Teso house and grain store will enable the reader to understand how careful these seemingly wild people are to make provision for the future.

Care is taken to protect the unmarried girls by making it compulsory for all young unmarried men of a family or village to sleep together in a hut set apart from the rest; and it is said that after these youths have retired the elders prepare the ground in such a way that trespassers are easily traced. This, how- 


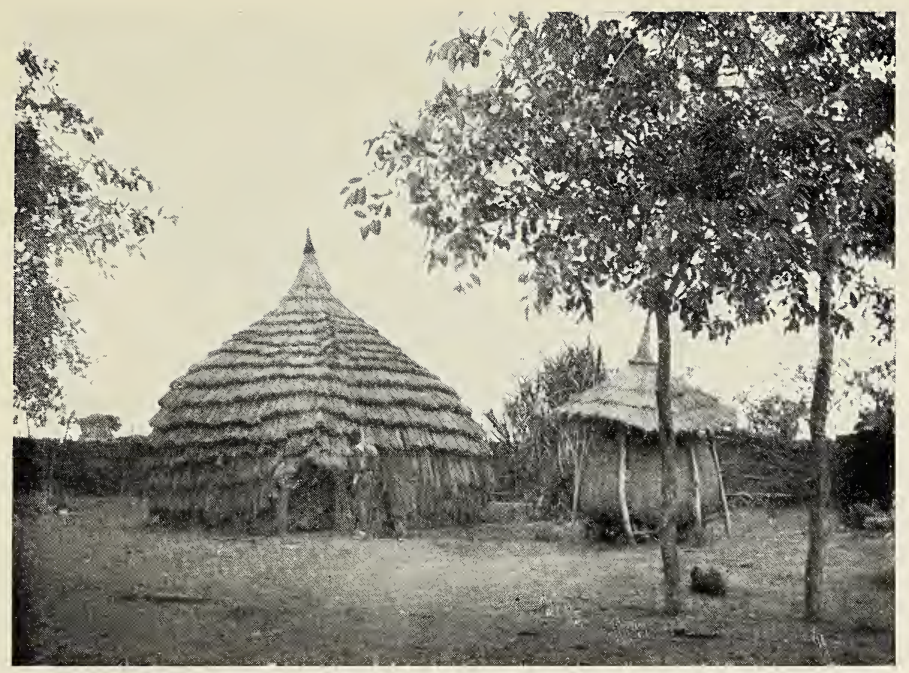

TESO HOUSE AND GRAIN STORE.

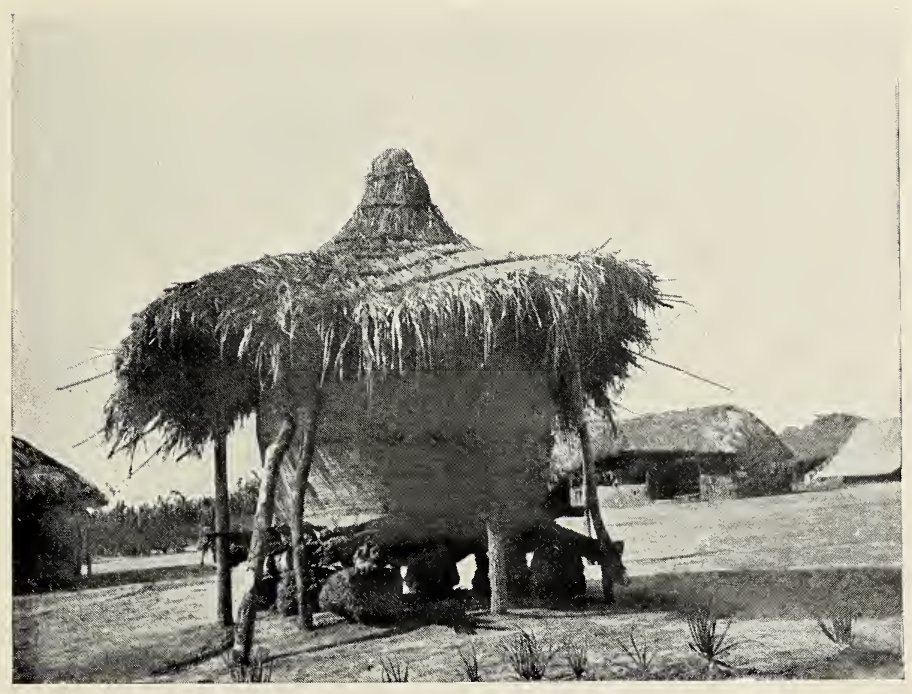

GRAIN STORE IN THE TESO COUNTRY. 



\section{Power of a Mother-in-law 255}

ever, is only done when flagrant advantage has been taken of the custom of the country for girls not to refuse when solicited.

When being taken round one of the villages by its chief, I was interested and amused at seeing a practical illustration of the awe with which a mother-in-law can inspire her daughter's husband.

The man was describing to me how that he was the head of his village, that men and women helped to till the ground and gather the grain; that sweet potatoes and bananas are also cultivated, but the bananas are not eaten for food but used for making drink.

$\mathrm{He}$ explained the necessity for guarding themselves with the strong cactus fence against the Kimam or Kimama people to the north-a people of less striking physique than the Teso, Koromojo, and Turkana tribes, but much more formidable fighters; and when in the middle of his explanation he suddenly stopped, gripped me by the arm and led me off at a rapid pace in the opposite direction. I was certain then some of the enemy had appeared. At the gate, however, he stopped in his flight and went on with the conversation as if nothing had happened.

Naturally I was inquisitive, and pressed him for an explanation, when he pointed in the 


\section{Uganda to Mount Elgon}

direction from which we had come and uttered the words "Mother-in-law." I chaffingly suggested that his description of things could not be correct, for he had told me that he was head of the village, and here he was afraid of his mother-in-law. He smiled, somewhat grimly I thought, but would not be persuaded to return by the same route. The lady was on the outlook for us, and at the same time anxiously endeavouring to protect herself from the shame of being gazed upon by her daughter's husband. A curious custom no doubt, yet one perhaps which makes for peace.

For the past five years Baganda teachers have been working amongst these people with encouraging results. Archdeacon Buckley and I have baptized young men from Miro and Bululu, on the shores of Kyoga, and have found them bright and intelligent; and two years ago some Teso lads from Kumi, near Lake Salisbury, were baptized by a Muganda clergyman whom I had placed there.

One of these lads came to live with me and teach me his language, but sickness intervened and I was invalided to Europe.

Since then the C.M.S. have appointed a European and his wife to live at Ngora, the centre of this Southern Teso district, with a million of people, where the first white woman 


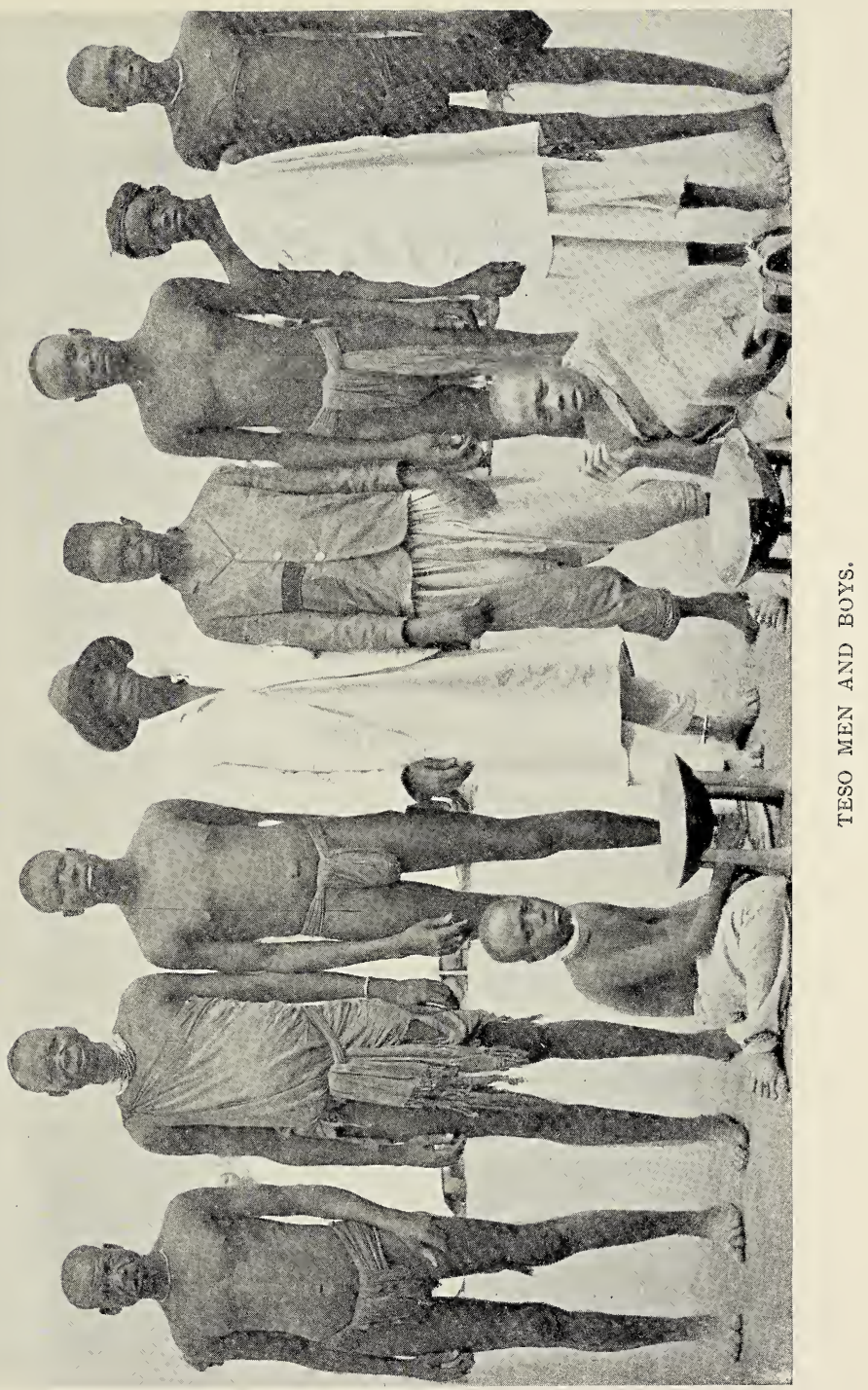





\section{Lake Salisbury}

the natives had ever seen-Mrs. Crabtree-was the wonder of the age; and where the present lady, if not driven out by malaria, will prove a tremendous influence for good. The perfect friendliness of the people at Ngora may be gathered from the fact that many were daring enough to brave the unknown powers of the camera.

Near by is Lake Salisbury, known to the natives as "Bisina," a not very beautiful or expansive sheet of water except in the rainy season when much of the surrounding land is inundated.

I was able to trace the distinct double connection between Lakes Salisbury and Kyoga formed by the rivers, or arms, Agu and Abuketi, marked on the map on pp. 220-221.

Fishermen and hippopotami hunters from Nsoga paddle up one or other of these arms into Salisbury.

Lakes Salisbury and Gedge are really one sheet of water in the rainy season.

From the shores of Lake Salisbury we got a glimpse of Mount Debasian, called Kokolyo by the natives, rising some twenty miles away to the westward like three huge jagged teeth.

Through the glass its cliffs and precipices 


\section{Uganda to Mount Elgon}

look inaccessible; yet perched on the very top of them are the dwellings of a people whose language and habits differ considerably from those of surrounding tribes.

This people, sometimes called Tegetha and Tepeth, are to be met with again on Mount Moroto, near Manimani, in the north; and since they are undoubtedly of Bantu stock, their presence so far north, and surrounded as they are by powerful Nilotic peoples by whom they are respected, is a striking phenomenon. I have often longed to visit them, and hope the opportunity to do so may come; but at present must content myself with the interesting question as to whether or not they are remnants of a great Galla invasion which passed over the Lake Rudolph district down to the south and south-west as far as the Ruwenzori Mountains and Lake Albert.

Away in the north, between Lakes Salisbury and Rudolph, dwell the powerful Koromojo and Turkana clans, blood relations of the Masai, closely allied in customs and manners to the Suk people of Lake Baringo district, and akin in language to the Teso people among whom we are now travelling.

Like the Teso, the Koromojo and Turkana men eschew clothing of any kind. They are big, strong, brave fellows, renowned as fighters, 
but vainer than the most frivolous woman with regard to trinkets and style of hairdressing. A Turkana warrior is a sight to be remembered, with his long hair thickly intertwined and hanging from his head exactly like a very thick, black doormat with the corners rounded off.

Where the hair is not long and thick enough to form of itself a sufficiently prominent headdress, it is encaked with potter's clay in which ostrich feathers, red berries, and pieces of reed are stuck, giving to the wearer a really terrible appearance.

The difficulty of sleeping with such a permanent head-dress is overcome by the use of a small wooden pillow, made with two prongs to stick in the ground, and the top carved to receive the neck of the sleeper. In the daytime it is carried on the arm of the owner by a thong of rough hide, and is always conveniently near when a seat is required.

For many years past Koromojo, Turkana, and Dobosa, or Toposa, have been open to the trader and ivory hunter, and indeed one might truthfully say have been under the supremacy of the ivory hunter-settlements of Arabs, Swahilis, and Baloochis. Now and then the depredations of these rascals have been suddenly ended by the swoop of a marauding 


\section{Uganda to Mount Elgon}

party of Abyssinians, but from either party the natives suffered grievously and still suffer, for there is no attempt to administer what is a fine and promising district.

Life in some parts of Koromojo and Turkana will always be somewhat difficult, especially in the hot season when water is scarce and sometimes disappears altogether; so that milk and blood have to be depended upon by human beings, and the wants of the cattle supplied from any underground accumulations of water that may be found by digging.

At present ivory is the chief export from these districts, and some idea of the number of elephants to be met with may be gathered from the rich haul represented by the accompanying picture.

There seems no difficulty in persuading men to undertake hardships for the purpose of gain -one young fellow is said to have cleared $£ 8,000$ profit in about nine months; but how few men there are-at the present moment nonewilling to answer the call of this vast district, to use the present grand opportunity, before the Swahili traders have forced Mohammedanism upon the natives, and before the evils of civilisation have ruined them, to go in and win the whole district for Christ!

What a glorious work might be done at 


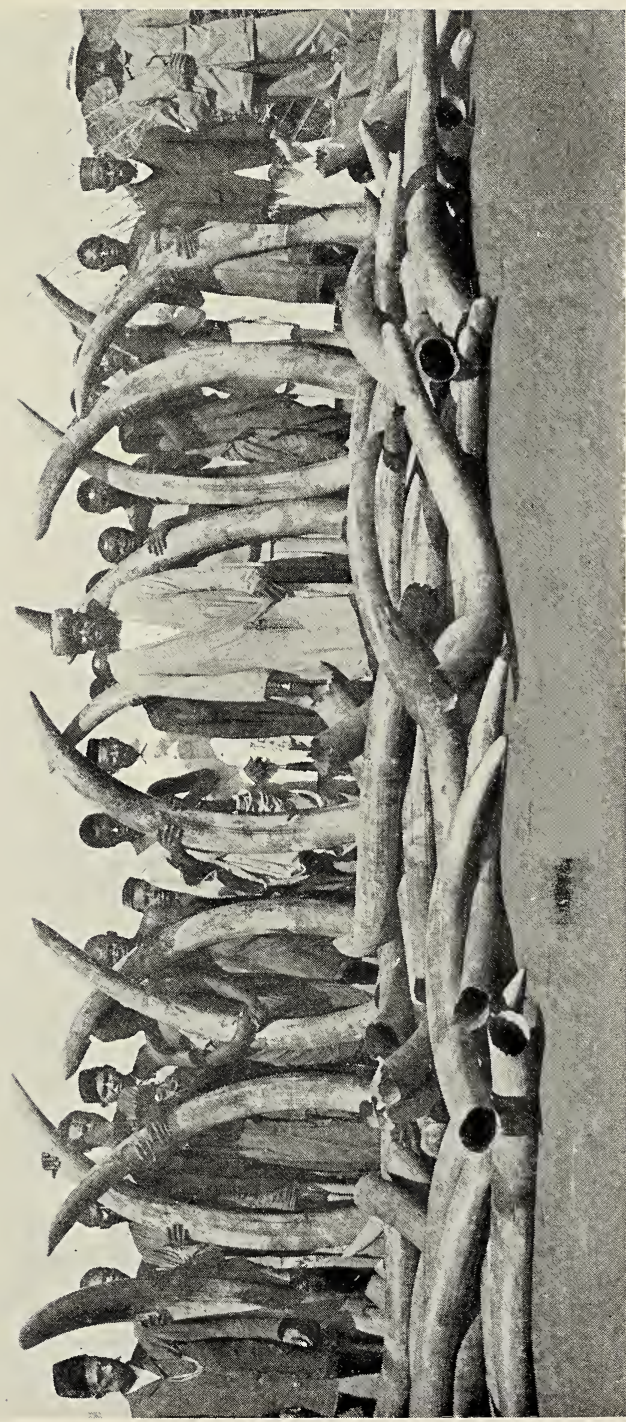

0
0
0
0
0
0
01
0
0
0
0
0
0
0
0
0 



\section{An Invitation from Abyssinia 265}

Manimani by a few earnest and practical young fellows-a clergyman, a doctor, and a couple of laymen!

Even Abyssinia recognises the opportunity, for not two years ago five Abyssinians travelled down from their own country through these districts to my station on Mount Elgon, and begged me to go back with them and see the many peoples by the way in need of a missionary. Four of these men claimed to be Christians, a remnant of the old Coptic Church -in this instance an example to more enlightened professors of the Christian religion.

I was too ill to move far from my own station, and in any case the work at Mount Elgon had the prior claim, but I hope the time is not far distant when men from England will be forthcoming to take up such a challenge as these Abyssinians gave.

At present we must turn our backs on the north and continue our journey southwards towards the great black mass we know to be Mount Elgon. 


\section{CHAP'TER XIII}

\section{MASABA : COUNTRY, PEOPLE, AND CUSTOMS}

A cool camp-The largest extinct volcano in the world-Mount Elgon and its foothills-Masaba-Primitive customsCaves and cave-dwellers-The wildest people in Uganda Protectorate-Native customs-Circumcision-Patriarchal government-Clan system-Land laws-HeirshipMarriage laws and customs-Dress of married women-. Clan marks-Ornaments-Protection of girls-Punishment of wrong-doers-Clan fights-Native courtesy-Spirit of independence - Jealousy - A father's curse - Curious customs.

TN the middle of the hottest season it $\mathcal{L}$ is possible to sleep comfortably at our last camp, Nabowa, or Napowa, for the cold winds from the largest volcano in the world have been blowing over us, and we rise refreshed to see a sight interesting and pleasing.

Right in front of us, apparently quite near, rises the extinct volcano known-no one knows 
why-as Mount Elgon. Its foothills stretch away vast distances to right and left, and appear on the north to join the peculiarly shaped mountain Debasian, or Kokolyo.

As a matter of fact the crater of Elgon must be some thirty miles from Nabowa, but at a distance of fourteen miles there rises abruptly a hilly plateau some 7,500 feet above sea-level, and this with a cloud hanging over its top at first sight appears joined to the crater.

All the hill region is known as Masaba, and until the last few years it has been quite cut off from the outside world.

There, on the hill in front of us, are men who offer sacrifices as in the days of Cain and Abel, and procure fire for the purpose probably in the very same way as those ancients by the rubbing of sticks.

On this western side are to be seen caves, which, though now only used as hiding-places in times of danger, were undoubtedly at no distant date the usual dwelling-places of the Bagishu.

Away to the south-east of Elgon the caves are still in use, though the bolder spirits are beginning to build in the open.

I have not the least doubt that the caves are originally natural, but have been enlarged 


\section{Uganda to Mount Elgon}

to meet the needs of growing families and herds.

A belt of "Kalungu," that is, uninhabited land, almost surrounds Masaba, and gives the country an uninviting appearance; but no sooner has this been crossed than Masaba is seen to be a land of plenty, beauty, and, because of its primitive simplicity, a land of wonder.

The long elephant-grass of Uganda and Usoga is absent, and as far as the eye can reach almost every foot of ground seems to be under cultivation, whilst innumerable clusters of houses are visible in every valley and on what appear to be inaccessible hills.

We left the last Government post more than twenty miles west of Masaba, but nowhere else in Africa did I receive a more hearty welcome or meet with a more kindly disposed people than in this country, where the people were living as they had lived right along from the past ages, and are described by the late Commissioner of Uganda, Sir H. H. Johnston, as "perhaps the wildest people to be found anywhere within the limits of the Uganda Protectorate. They are wilder even than the Congo dwarfs."

Such a character almost appalled one, but 


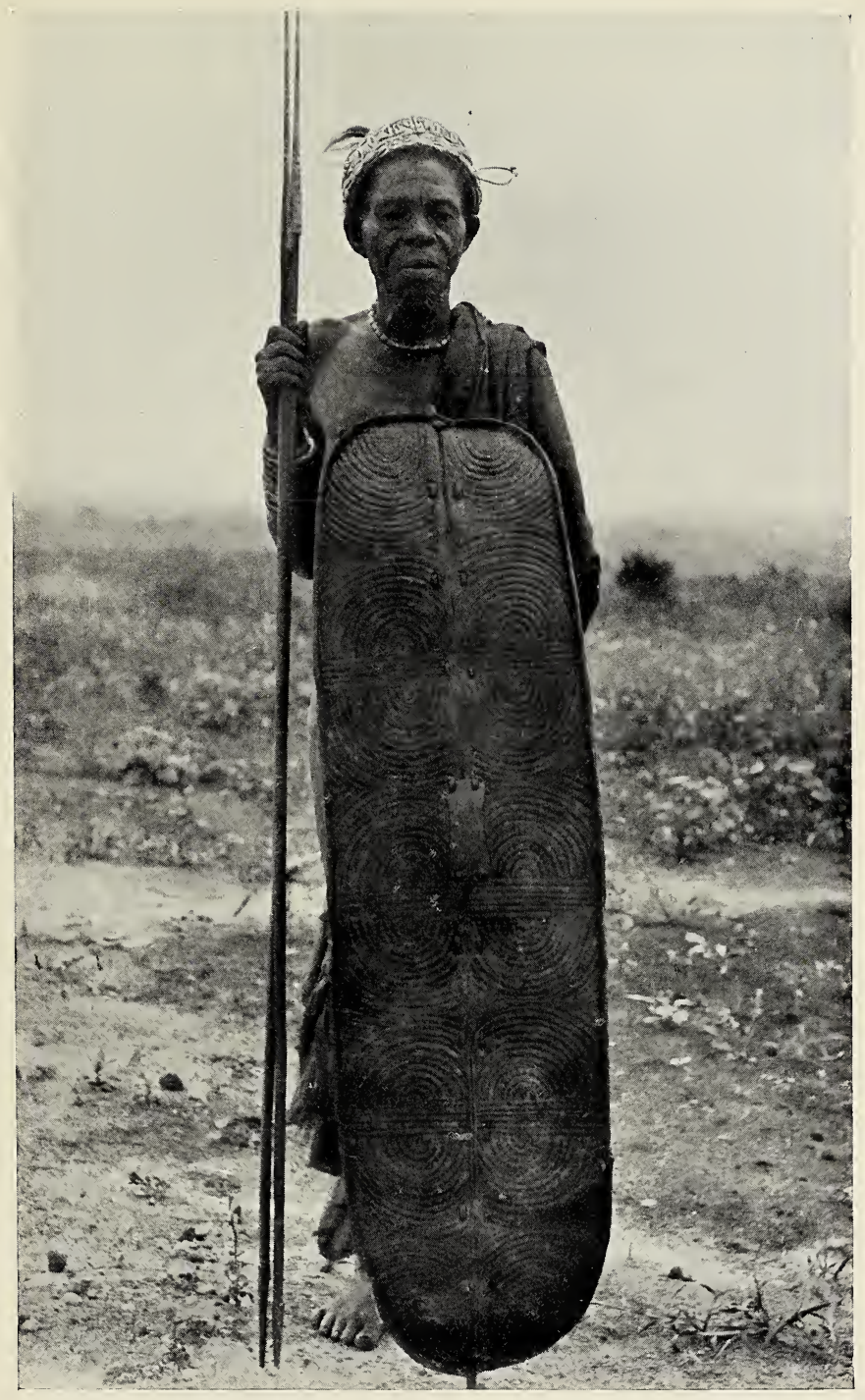

AN OLD MASABA PATRIARCH.

269 



\section{Primitive People and Customs 27 I}

four years of life among them proved them not only very kindly but very capable of development.

A primitive, pastoral, Bantu-speaking people, they are known as Bamasaba or Bagishu, but distinguish themselves as a race apart from others by the name Basani, i.e., men, whilst all men of uncircumcised nations are called Basindi, i.e., boys.

There is an annual festival of circumcision, when all youths who wish to be recognised as full members of the clan, warriors, and men to be reckoned with, parade, dressed in war dress, and march from village to village to make public their brave decision.

They are fêted by young and old for days before the actual operation, and they visit the sacred grove of the clan, and, having made their offerings, receive through their witchdoctor the blessing of the spirits.

The final operation is carried out by adepts, who receive a fowl from each lad.

This operation is performed in public, not in one centre, but in various places situate as near as possible to the homes of the young men concerned.

Each patient has to stand forward, grasp a young sapling with both hands, and stand without flinching whilst the foreskin is cut 


\section{Uganda to Mount Elgon}

away. On the least show of cowardice the patient is fiercely beaten with sticks by the onlookers, but at the close of the operaton is treated with great care and consideration until better.

A house is set apart for the young men suffering, and they are carefully tended night and day until better.

As a rule, the youths are nude until circumcision, after which they wear a skin apron.

The form of government has only reached the patriarchal stage; and this explains the reason for the independent village life found in Masaba. Ten, twenty, thirty, and as many as a hundred houses are clustered together, sometimes fortified with a strong mud wall and deep trench; and in these dwell the wives, sons, grandchildren, and other relations of the chief man, who is the old patriarchal head or son chosen to succeed him.

The old patriarchs long ago took clan names, and instituted the clan system whereby the land of the country was fairly apportioned and settled on a satisfactory basis.

Each clan owns a definitely marked strip of land running towards the principal mountain heights.

Each adult male individual of a clan can claim a piece of this strip. No land is ex- 


\section{Native Land Laws}

changed, but any individual may sell his land, and often does sell a portion of it. No chief may interfere, for the Masaba chiefs are not chiefs in the feudal sense and do not own the land more than any other householder. Each male has an independent right over his own land, and no chief can turn him away, as is the case under the feudal system.

The land is hereditable, and on the death of the father, if married sons only remain, they share alike. If married sons and young children are left, the eldest son takes charge on behalf of the young male children. He and the other married sons may share the cattle with the children, but the land is kept for the children.

If there is more than one wife, and each wife has children, the male children fall heirs to the land cultivated by their own mother.

If there be only one wife, with issue of sons, the sons divide the estate.

The heir to the chieftainship-i.e., representative of the family-is elected by the male relatives of the deceased, and is always a son.

A person may change his clan to enter the clan of his mother, and he may succeed to 


\section{Uganda to Mount Elgon}

land in both the clan of his father and of his mother.

Members of the same clan do not intermarry.

The clan feeling is very strong, and each individual is intensely loyal to the call of the clan in time of need. An insult offered to the humblest individual is offered to, and will be resented by, the whole clan. Consequently the clans are often at variance. Their petty jealousies prevent any cordial co-operation or amalgamation, even in time of direst necessity, and this makes missionary and probably any other kind of work among them very difficult.

There is little doubt, however, but that this condition of the people has been of some assistance to the Government, for such a thing as organised opposition is quite out of the question.

The strongest patriarch, or chief, is the man who has been able to procure the most cattle, and with them buy the largest number of wives, for each of which he would have to pay from two to ten head of cattle, according to age and condition.

The suitor for a lady's hand approaches the girl's father and discusses the price of his choice in cattle. These negotiations often last a considerable time, until at last 


\section{Marriage Customs}

the bargain is struck and the cattle paid over.

For the space of three months not a sign is given that the arrangement is complete; the woman is still in her father's house, and things go on as usual in the house of her suitor.

At the end of this time the lady's father kills a goat, and friends-except the prospective bridegroom and his clan-and relations are invited to partake of a feast at his house, after which a procession is formed, composed of the bride-elect, escorted by thirty unmarried girls of her acquaintance, the foremost of whom carries the head and skin of the goat which formed an important item in the recent feast.

Before and behind these females march young men, decked out, like the girls, in all the glory of beads and iron wire.

Behind all come some men, related to the bridegroom, carrying earthenware pots full of strong drink made from grain. The more common drink made from bananas is not used on these occasions.

On arrival at the house of the bridegroom a mimic war takes place, to convey the idea that the two clans are fighting for the lady. 


\section{Uganda to Mount Elgon}

If the bridegroom-elect is still uncircumcised the bride and her retinue stay for two days to cultivate whatever plantain garden the gentleman owns.

If, however, the bridegroom-elect is, from the Bagishu point of view, a man, they stay three days, eating, drinking, working, and playing.

Anything of an unseemly nature is strictly taboo; and as the man and woman most closely concerned are not yet married, they stay apart from each other.

At the end of the second or third day the bride-elect returns with her retinue to her father's house and there remains for one or two months, after which another goat and fowls are killed, plantains cooked, strong drink brewed, and every preparation made for a great feast.

Married men are sent by the bridegroom with jars for the drink and baskets for the food. The procession is once more formed, this time without the young men, and the lady is brought to her husband.

Friends and neighbours and all who will from far and near, except the father and mother of the bride, assemble to eat the marriage feast, at the close of which the bride, now arrayed in the symbolic dress of a married woman, is 


\section{Dress of Married Women 277}

escorted by the bridegroom to her future home. A house and grain store are provided for each wife, and as a rule the women settle down after marriage to a quiet, loyal, and fairly industrious life, cultivating, cooking, bringing firewood and water, counting and restringing her beads.

The distinctive dress of a married woman is a fringe of light-coloured string, made from plantain fibre, tied round the waist at the back, then gathered together, passed between the legs, and tied to the string in front.

There is also a small black string fringe, without which no well-bred woman will approach her husband to serve food or even be without in a man's presence.

There is no distinctive dress for the younger women, but they are strictly careful to wear a piece of cloth or leaf or plant.

When the young men are considered old enough to marry, and become full members of their clan-i.e., at from sixteen to eighteen years of age-they are circumcised; and the young women, on attaining the age of from fourteen to sixteen years, are marked on the abdomen and forehead with the tribal marks, cut after having been perforated by some old lady of the clan.

Sometimes the wounds fester and form one 


\section{Uganda to Mount Elgon}

large keloid which looks very like a doormat tied to the abdomen.

It is also customary for the women to perforate the lower lip and gradually enlarge the hole until they are able to wear, comfortably, I suppose, a piece of wood half an inch in diameter or-the height of ambition-a large piece of white quartz two or three inches long.

Both men and women are fond of ornamentation. They wear beads of every kind, shape, and colour, and whatever coloured bead is the fashion becomes the currency for the time being. Necklets, bracelets, and anklets of iron and brass, some of them exceedingly heavy, are greatly sought after; waistbands, too, of ostrich eggshell, cowrie shells, and iron are very popular, and hippo teeth, rams' horns, leg bells, shell and monkey-skin hats are worn to add dignity to festive occasions and to inspire awe in time of war.

At the age of about ten years both boys and girls leave the house of their parents and take up their quarters in houses provided for them, girls in one house, boys in another.

I have already referred to the care taken by the non-Bantu people in Teso to ensure the safe keeping of their girls at night-time. The people of Masaba are not so particular; there are certain penalties attached to wrongdoing, and 


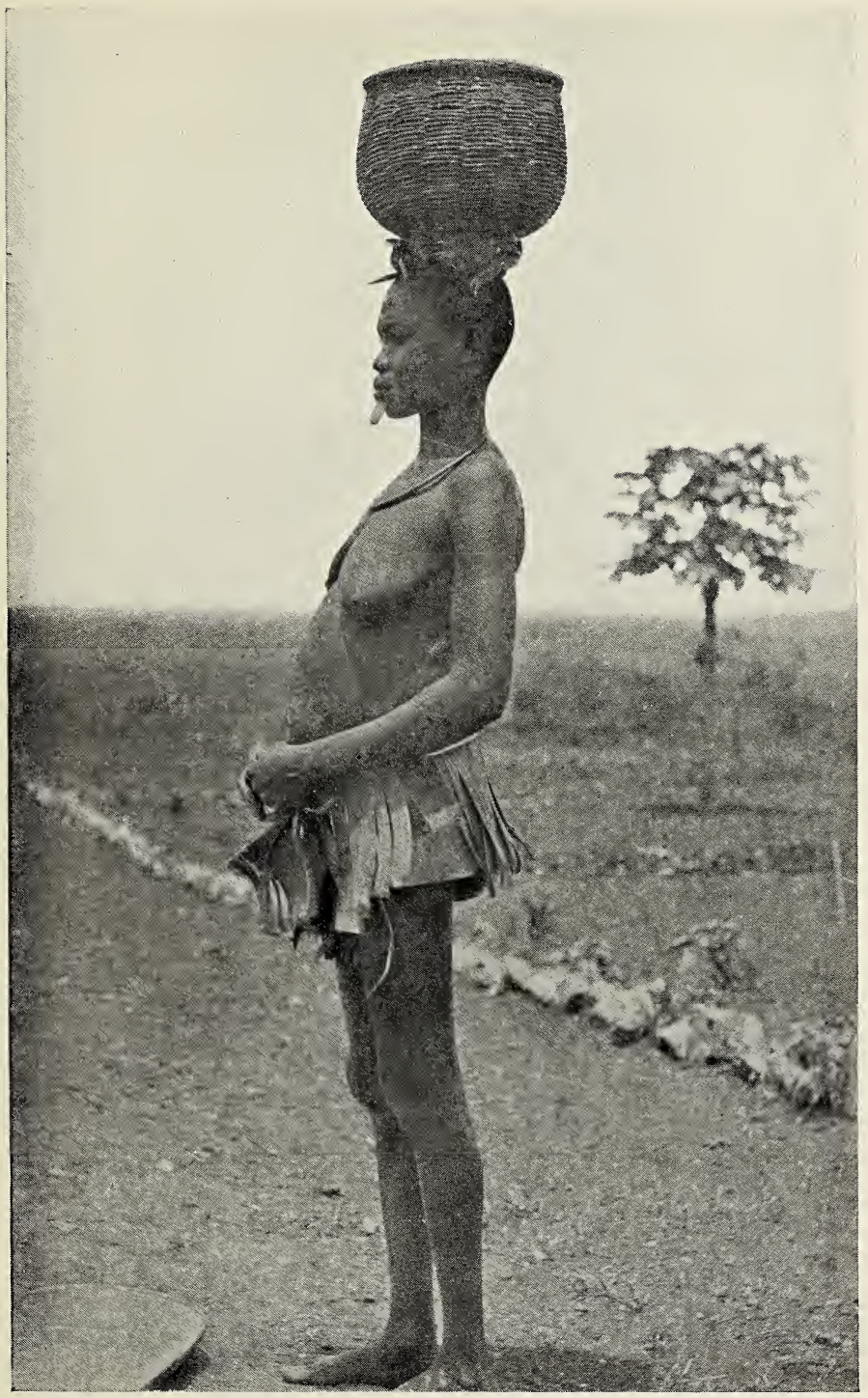

MUGISHU WOMAN WEARING LIP STONE. 



\section{The Protection of Girls 28 I}

if the young people are foolish enough to brave them they cannot complain of the punishment.

A father who has been given cause for suspicion will hide himself in the grass near the house of his daughter and wait night after night until he knows for certain whether his confidence has been betrayed.

Woe betide the guilty youth! The whole village is aroused, and the elders, with all the male relatives of the girl, fall on him with sticks and beat him until he wishes he had never been born.

And here let me state a fact, hardly comprehensible to Western minds : in nearly every case of solicitation the girl is the culprit.

When without a marriage according to native custom a child is expected, the girl is severely punished by her father or brothers; indeed, their anger often leads them to the length of spearing her, after which they will bring her to the European to be doctored.

There is no idea of shame in the question, but the marketable value of a girl drops on account of her condition, and instead of the marriage allowance being from four to ten head of cattle her relatives can only get from two to four.

There seems no great difficulty in finding a 


\section{Uganda to Mount Elgon}

husband for such a girl, and I have not the least doubt but that the reduced price tempts suitors.

The child, which to the native mind is illegitimate, goes with the mother and becomes the property of the husband.

It might have been supposed that in the event of the child being a girl a larger number of cattle would be demanded and gladly paid; but no, the woman and her child go for the smallest possible price without a sign of festivity or joy; and we may take it for granted that the voice of the nation has settled this and other unwritten laws for the, social welfare of the whole community.

Much of the trouble between clan and clan is caused by unsatisfactory marriages. It is an understood thing that if a wife leaves her husband and returns to her father without having borne a child, the marriage is dissolved by the father returning to the husband all the cattle.

If a child has been born the cattle are returned less one killed to give a feast to the wife's friends and relations. But if there are a number of children the cattle are not returned.

It is undoubtedly difficult to get any African to return cattle that have been in his possession, and the above marriage laws often lead to squabbles and even serious feuds because a wife 


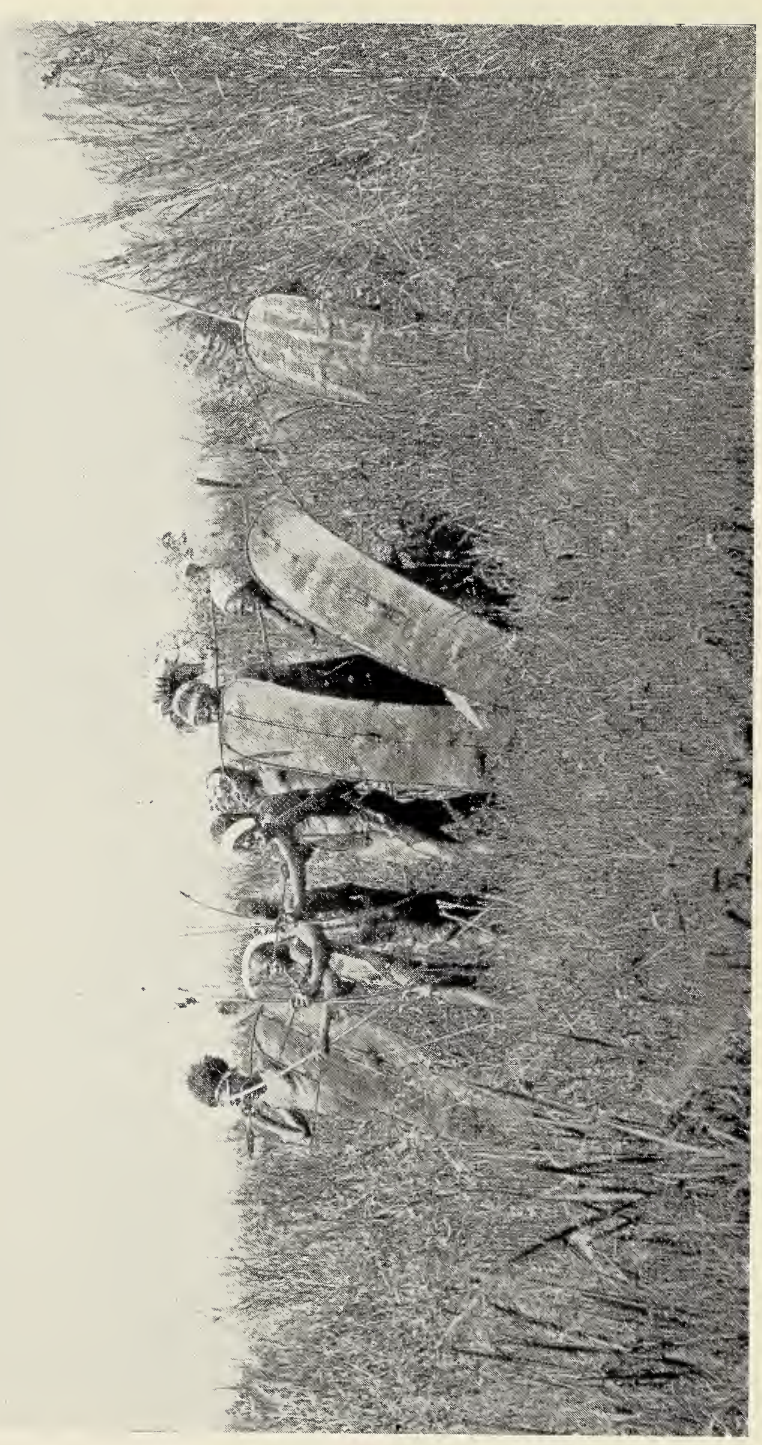

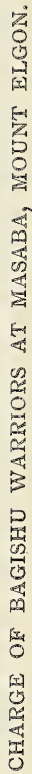




\section{Clan Fights}

has left her husband to return to her old home, and her father is too strong for the husband, who dare not even go near to claim his own.

As a rule the wrongdoers and the wronged person are supported by their respective clans, and this sometimes leads to a regular battle, such as I have witnessed more than once.

The men of each clan arm with spears, knives, sticks, bows and arrows, and meet for battle on the boundary.

Charge after charge is made, heads cracked, and spear-wounds given, and it may be a man on each side killed; but this does not often happen, except in a drunken brawl.

As a rule the clan fights are carried out with the utmost good-humour, and when either side is tired, the others are quite willing to stop fighting until their opponents feel refreshed; they would not think of taking a mean advantage under such circumstances.

If a man is speared, his friends are allowed to carry him off the field, and unless there is bitter hatred between the clans the fight is not continued on that day.

No clan would dream of molesting a woman belonging to the opposing force. She might with perfect safety walk between the combatants, and is even allowed to pass in 


\section{Uganda to Mount Elgon}

safety through the enemy's territory, taking her husband's goats or other possessions to some place of safety.

Indeed, considering the conditions of life in Masaba, it is a wonderful fact that women are very much respected. They hold a much higher position in the country than was the case only a few years ago in Uganda, and is to-day in Usoga and other countries in the Lake district. The Masaba women do not rank with the goods and chattels, but receive respect in youth and honour in old age.

The spirit of independence has been markedly developed in the people, no doubt owing to the fact that the nation is not organised under one head, and the consequent necessity for each person to look after himself or herself. A child will defend with its life its own small property, perhaps a single fowl, and dare its father to use it for himself. A wife will deeply resent any claim of ownership over her made by her husband, yet will be strictly loyal to him until he begins to neglect her claims and rights.

It is sometimes necessary for the husband to assert himself in a manner painful yet salutary to his wife; but when the woman has been in the right, and has taken steps to defend herself, her methods are usually 


$$
\text { . }
$$




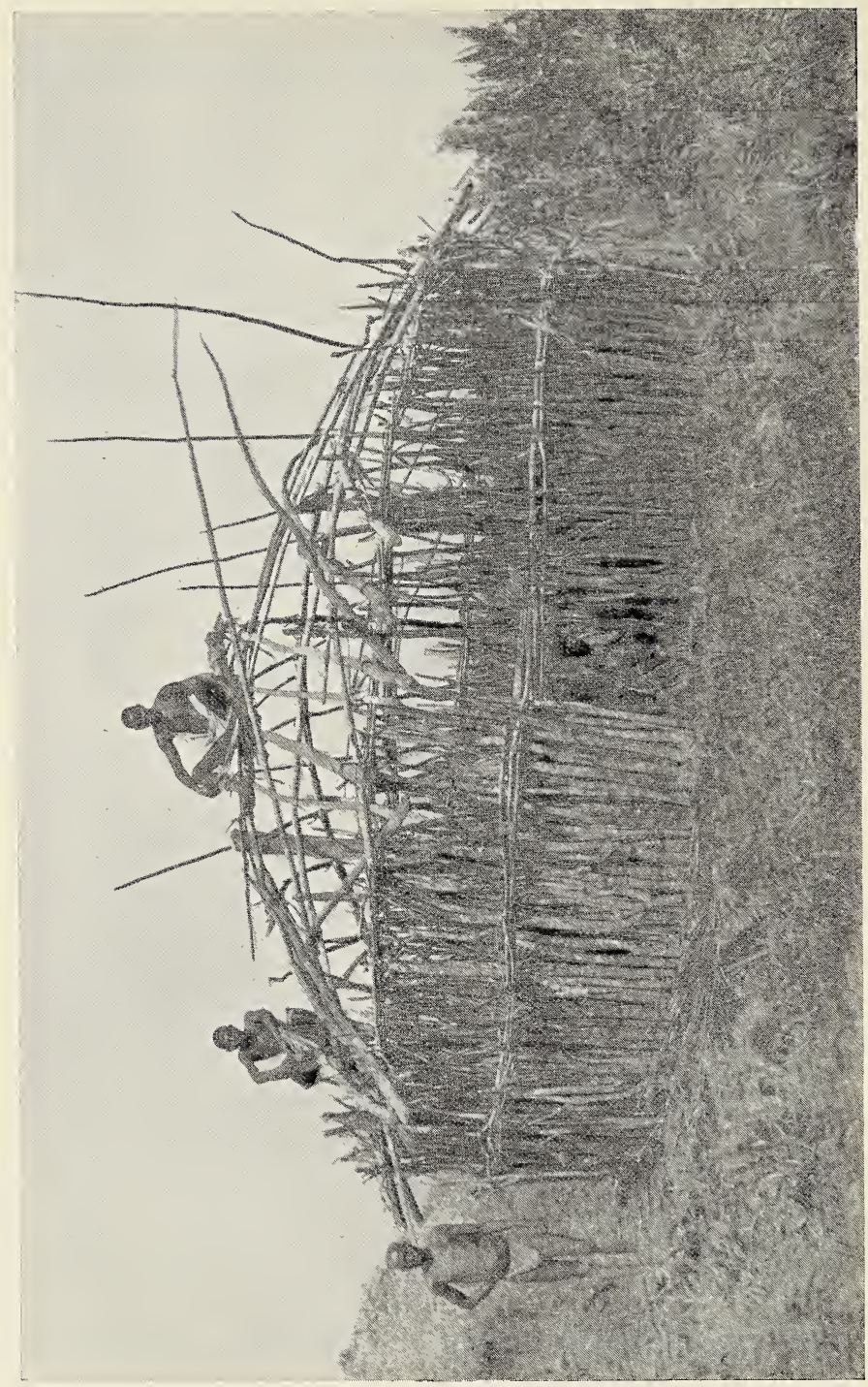

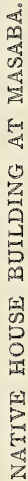




\section{Maintaining Women's Rights 289}

so drastic that an operation or funeral is necessary to the husband.

Such cases I have had brought to my notice, and must confess that in one such I found it quite difficult to impress the lady with the wrongness of sticking a knife into her husband's back, within an inch of his spine, for she was quite convinced that he deserved it, and had an idea that I thought so too. She promised, however, not to do it again, and gladly left her husband in my care until cured.

The system of polygamy is not responsible for the amount of domestic trouble it is generally supposed to engender. Each wife has her own house, the framework of which is built by the man and his friends, whilst the lady and her friends carefully mud the walls and beat the floor. Outside this house are one or two grain stores, where the lady stores up the last grain harvest as a safeguard against a prolonged dry season when the banana supply gives out.

Sometimes, however, a spirit of jealousy creeps in between wives, and then nothing goes right. Each wife is on the watch for any act of the husband that can be construed as favouritism, and the slighted one begins to plan revenge. 


\section{Uganda to Mount Elgon}

In one case the husband was made to suffer, when, after a day's outing at some drinking party, he returned and demanded admittance to the house of his slighted wife. They quarrelled as to who should open the door, they fought when he got inside, and when, overcome with drink, he sat down dozing at the fire, the woman was so carried away by her mad passion that she crept up behind and killed him there with his own axe.

In another case, the two women came to extremes after bickering and insulting each other for weeks. The favourite wife invited the other to fight the matter out fairly before witnesses, but the witnesses happened to sympathise with the other wife; consequently they held the favourite whilst the second wife tried to cut her head off with a large knife. The woman was terribly cut, but she got off and raised her clan, who first of all sought the weak husband and murderous wife before bringing the injured woman to be attended to at our dispensary.

Although the spirit of independence is so marked, even in the young, there is no lack of parental authority. This is no doubt due to the power of a father's curse. The word "Kutsuba" is dreaded, for to "Kutsuba," or 


\section{The Power of a Curse 29I}

curse, one's child is the severest punishment a father can bestow. The son so dealt with becomes a wanderer, not because his father has cast him out, but because he believes in the power of the curse, and by the action of his own mind brings upon himself what his father's words would have been totally incapable of-utter destitution of health and wealth.

He roams from place to place, unable to fix his attention for long upon anything. He takes pleasure in nothing, and even when married he will leave his wife and all belongings and periodically disappear.

This punishment is given to a son for gross impertinence to or for threatening a father; and to a daughter for marrying without a marriage arrangement, i.e., before her father has received the usual number of cattle.

In the daughter's case the punishment falls heavily upon her husband and herself, for she will either be childless or her children will die at or soon after birth. Case after case has been pointed out to me where my informants declared the curse had indeed had this effect, and one couple I know quite well have recently taken steps to have the curse removed after losing three children, one after the other. Such is the influence of mind over matter. 


\section{Uganda to Mount Elgon}

The removal of the curse is effected by the son or daughter, as the case might be, bringing to the father a goat or sheep which is killed and eaten by the two most nearly concerned in the matter, and all their friends and relations. During the feast the father takes the contents of the animal's stomach and with them smears his son or daughter, who goes forth to show all the clan that the curse has been removed.

Many of the Masaba customs, such as the one just mentioned, are exceedingly curious, and the people cannot give or suggest a reason for them. They have another, well worth mentioning, the meaning of which is, I think, quite conceivable to European minds.

When two clans have been engaged in war, and each has tried in vain for the mastery, they decide to make a compact which no man or woman would dream of breaking.

A dog is brought to the boundary and there cut in two, where so many fights have taken place. One half is placed on the land of one clan, and the other half on the land of the other clan, and the warriors of each clan march in procession between the two halves, which are then spurned by both parties.

There is much hand-shaking and merriment, and from that time the clans are friendly. 


\section{A Unique Compact 293}

There is little doubt but that the idea at the root of this custom is the wish that whoever breaks the compact may have an end like the dog-disowned, cut in two, and spurned. 


\section{CHAPTER XIV}

\section{LIFE AND WORK AMONGST CANNIBALS}

Lost near Mount Elgon-Quaint figures-Clothing despisedInvalid missionaries-A cheap house-Human hyænasThe place of departed spirits-Burial customs-The gathering of the clans-The coming of Roman CatholicsLaying out a station-Native kindness-Progress-A unique church dedication-Variety of work-Healing powers of nature-First baptisms.

TN September, 1903, my wife and I found 1 ourselves hot, hungry, and very tired, struggling through banana gardens in the country at the foot of Mount Elgon, and making for a hillock which seemed to be further away every time we caught a glimpse of it.

Our porters had lost the way and we were alone, yet not as much alone as we could have wished, for almost at every step we took we had evidence of company that at the time was not much to our liking. 


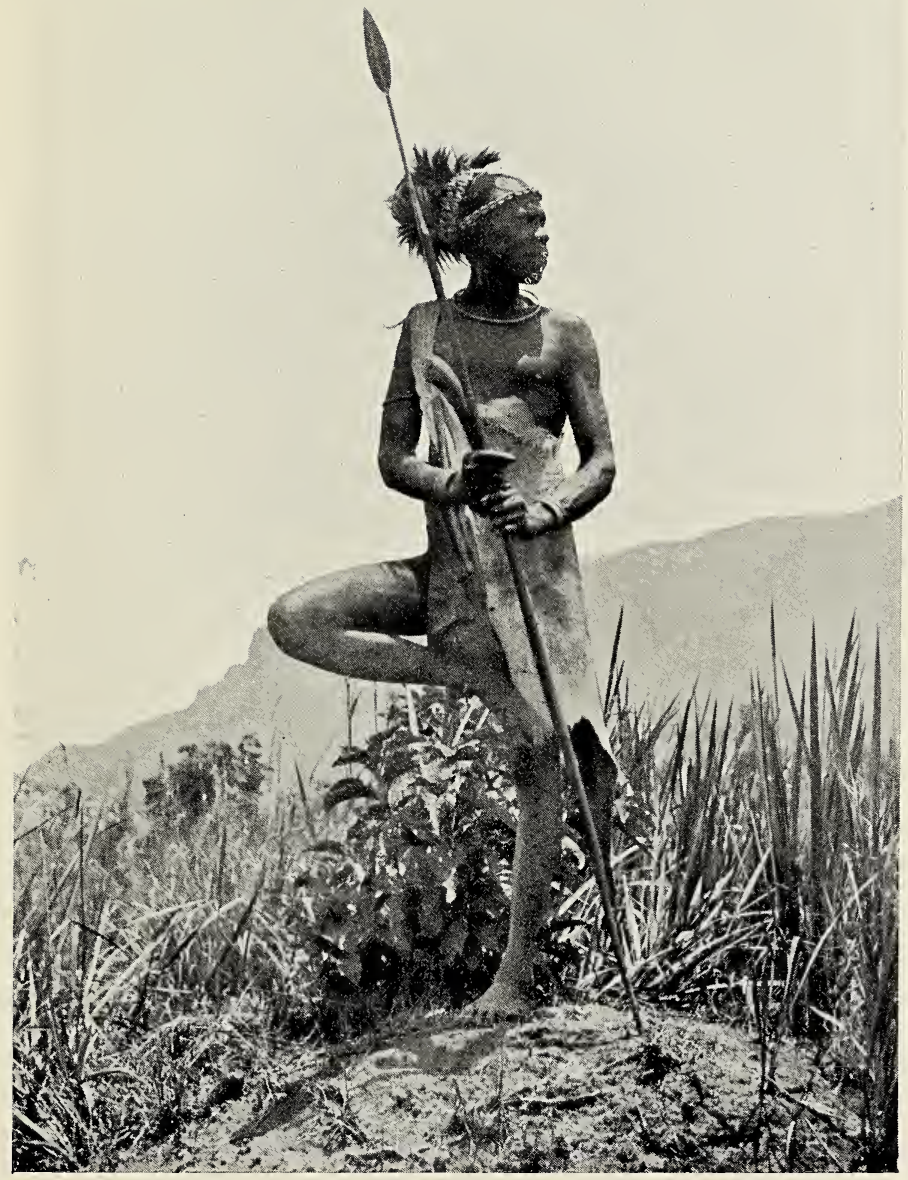

"A TALL. IMPRESSIVE Figure" NEAR MOUNT ELGON. 



\section{A Trying Journey}

A tall, impressive figure, naked but for a dressed goat-skin, and armed with one or two spears, would stand and look at us, utter a few words that were unintelligible, and then disappear. Then a group of men and women with less clothing than we had ever conceived it possible for human beings to wear in public, forced their attentions upon us, but were unable to make us understand their welcome or direct us to our destination.

A few more miles had been covered, and the hill we were making for seemed as far off as ever, when two youths, absolutely nude and armed with long sticks, introduced themselves to us with loud laughter and much gesticulation. They made us understand that they would guide us to our destination, and we meekly followed at a much slower speed than they were evidently accustomed to; but this no doubt gave them greater opportunity than they would otherwise have had of explaining to all onlookers who they thought we were, and how nearly we were related to them since they were our guides.

They did not disappoint us, for after what seemed an interminable journey, we saw evidence of 'civilisation, and hurried with 


\section{Uganda to Mount Elgon}

lighter hearts towards a distant umbrella. Imagine our disgust and disappointment to find that it covered an aspiring African escorted by a crowd of admirers, who were far more interested in this native parade than in the advent of two Europeans.

A few yards, however, brought us to the euphorbia fence of what was to be our home, and there we met the two English missionaries, the Rev. W. A. and Mrs. Crabtree, who, some time before, had come out from Uganda to have a holiday in this district, with the Uganda chief, Semei Kakungulu, and were so impressed with the needs and opportunities in this part of the world, that they did not go back to Uganda, but stayed on in Masaba, lived in the chief's house after he had left the place, made friends with the people, and generally prepared the way for us.

I found them both broken in health, and speedily got porters together to take them to rail-head at Kisumu, a distance of a hundred miles.

When Mr. Crabtree heard of our location to Masaba he got the natives to prepare quarters for us. A small, round hut which had served as a small-pox hospital was put in order for our boys, and a shed which had been erected to keep the sun off some 


\section{A Cheap House}

visitor's tent was made into a house by the Masaba women filling in the sides and ends with wet mud. A hole was left to serve as window, and another as doorway, and these were covered at night-time, and when it rained-as the rainy season was on, it seemed to be always raining - by doors made of reeds.

I have never yet dared to ask my wife what she thought when on that first evening I led her into that shed and told her we should have to live there for some little time. My own feelings were somewhat intense, for what I had treated as a joke when I heard that an application had been sent to headquarters for 1 rupee ( $1 \mathrm{~s}$. $4 \mathrm{~d}$.), the cost of my house, I now realised was grim reality.

The walls were wet, the mud had not even begun to crack as a sign that it was drying; the floor was considerably lower than the outside earth, and a convenient ant-hill just outside the door turned all the water into the house. I was-well, I had better not say what I was !--and my feelings were not relieved when my wife complained of headache, and in spite of every precaution, eventually went down with a temperature of $103^{\circ}$.

We removed her to the Crabtrees' house, a 


\section{Uganda to Mount Elgon}

small mud and thatched affair, bequeathed to Mr. Crabtree by a native chief.

Infested though it was with rats and snakes, and responsible no doubt for the ill-health of our predecessors, it was incomparably better than the wet shed outside.

Our first care was to cut down the thick fence of euphorbia, which gave to the place the aspect of a fort.

The Bamasaba were delighted to think that we were not afraid of them, and were willing for them to come about us at all hours. They wondered what would be the next move; and I did not leave them long in doubt, for suspicious smells had been troubling us until we could stand them no longer, and having decided to follow one up, I soon found out the reason of all the others; the natives of Masaba do not as a rule bury their dead, and the long grass surrounding our house was a most convenient place in which to deposit the corpses.

The condition of the atmosphere immediately near us before that long grass was removed may be faintly imagined, yet would have been infinitely worse but for the work of human hyænas who leave very little for the four-legged animal.

The custom of throwing out the dead is 


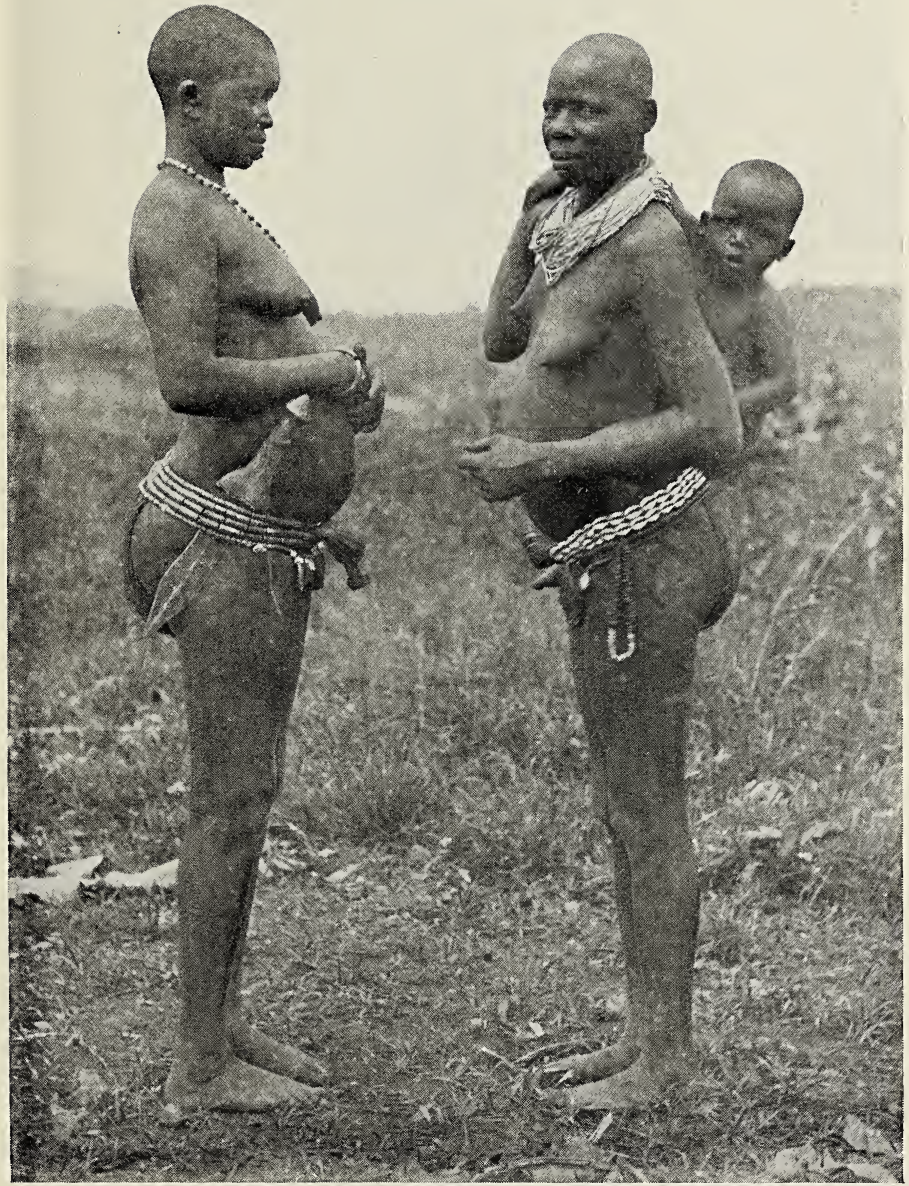

BAGISHU MARRIED WOMEN. 



\section{The Place of Departed Spirits $3 \circ 3$}

universal among all the clans of Bagishu, except in the case of the youngest child or the old grandfather or grandmother, for whom, like the child, a prolonged life on earth is desired.

As a general rule, it is believed that when the spirit leaves the body it goes to Makombe, the place of departed spirits, which is a very similar place to this earth, for there men meet all friends who have gone before, and come once more into possession, even if they have to fight for them, of all cattle that once belonged to them, but had died or been killed.

The hills of Makombe are beautiful, providing luxuriant and everlasting pasture, and death is quite unknown. It is sometimes said that Were (God) is the great ruling spirit of Makombe.

When it is desired to perpetuate on the earth the life of some old man or woman, or that of some young baby, the corpse is buried inside the house or just under the eaves, until another child is born to the nearest relation of the corpse. This child, male or female, takes the name of the corpse, and the Bagishu firmly believe that the spirit of the dead has passed into this new child and lives again on earth. The remains are then dug up and thrown out into the open. 


\section{Uganda to Mount Elgon}

The hyæna is the chief scavenger of Masaba, and is sacred in the eyes of the people. It is not classified in the language as other animals, but has received a name which puts it on a level with persons.

The work of clearing the ground for a mission station was a big task, but the people undertook it willingly when they realised that I meant to pay them for their work. Large crowds came each day, and if only they had really worked the whole place would have been cleared in a very short time. But different clans had to exchange compliments or epithets that were anything but complimentary, and it sometimes looked as if the mission station was about to be turned into common ground where long-standing clan disputes were to be settled by any and every means.

Expostulation by a European who could hardly make himself understood went for very little, but a threat to give no pay-the currency was small white beads-for that day generally induced them to do a little work.

On the whole the Bagishu worked regularly until a more serious interruption than usual took place, namely, the advent of the Roman Catholic Mission. They had built a small shed, a mile from our station, when the C.M.S. missionary Crabtree took up residence at 


\section{A Roman Invasion 305}

Masaba, but they had never permanently occupied it. Now, however, the bishop and two priests came to inaugurate a more permanent settlement, one mile from my door, on the land of the same clan; and that although there was no other mission station for a hundred miles to the south, some hundreds of miles to the east, and thousands of miles to the north, all teeming with population.

The priests had to do what they were told, but undoubtedly they realised as I did the sad pity of such a move, which tended to degrade the mission of Christ's professed disciples to the level of trade competition.

There was much to try us, for the natives are cute enough to play one European off against another, if possible; but we laid ourselves out to understand each other, and as a result became fast friends.

In May, 1907, I journeyed from Masaba to Uganda. I had been down with a slight attack of blackwater fever early in the year, and got out of bed to make the journey. Ill and wretched, I called on the Roman Catholic priest, Father Kirk, at Budaka, and he would fain have had me stay with him until I felt better; but I determined to push on, and was much touched and grateful when later in the day a 


\section{Uganda to Mount Elgon}

messenger from Father Kirk came into my camp with some milk and a bottle of wine. I was not destined to see him again, but I wrote my thanks, and since coming to England have received a letter from the priests in "Bukedi," full of kindly sympathy at my being invalided and speaking much too generously of the work God enabled me to do in that land.

I know, too, how grateful my wife is to Father Spere, of Masaba, for his kind sympathy and help when I lay ill in Uganda, and my fellow-worker, Mr. Holden, was enjoying (!) a temperature of $104^{\circ}$ at Masaba. The Roman Catholic priests and the strongly Evangelical yet Catholic C.M.S. missionaries at Masaba, and $I$ am certain in other parts of Africa, live and work happily together because they realise that the true issues of life do not depend on minor shibboleths. Without trespassing on private judgment and opinions, we learn to know and respect each other's work for something like its true value.

Eventually a large clearing was made, roads laid out, and a mission station planned which would contain a church, schools, dispensary, teachers' houses, house for boarders, house for European in charge of district with accommodation for visitors, house for Euro- 


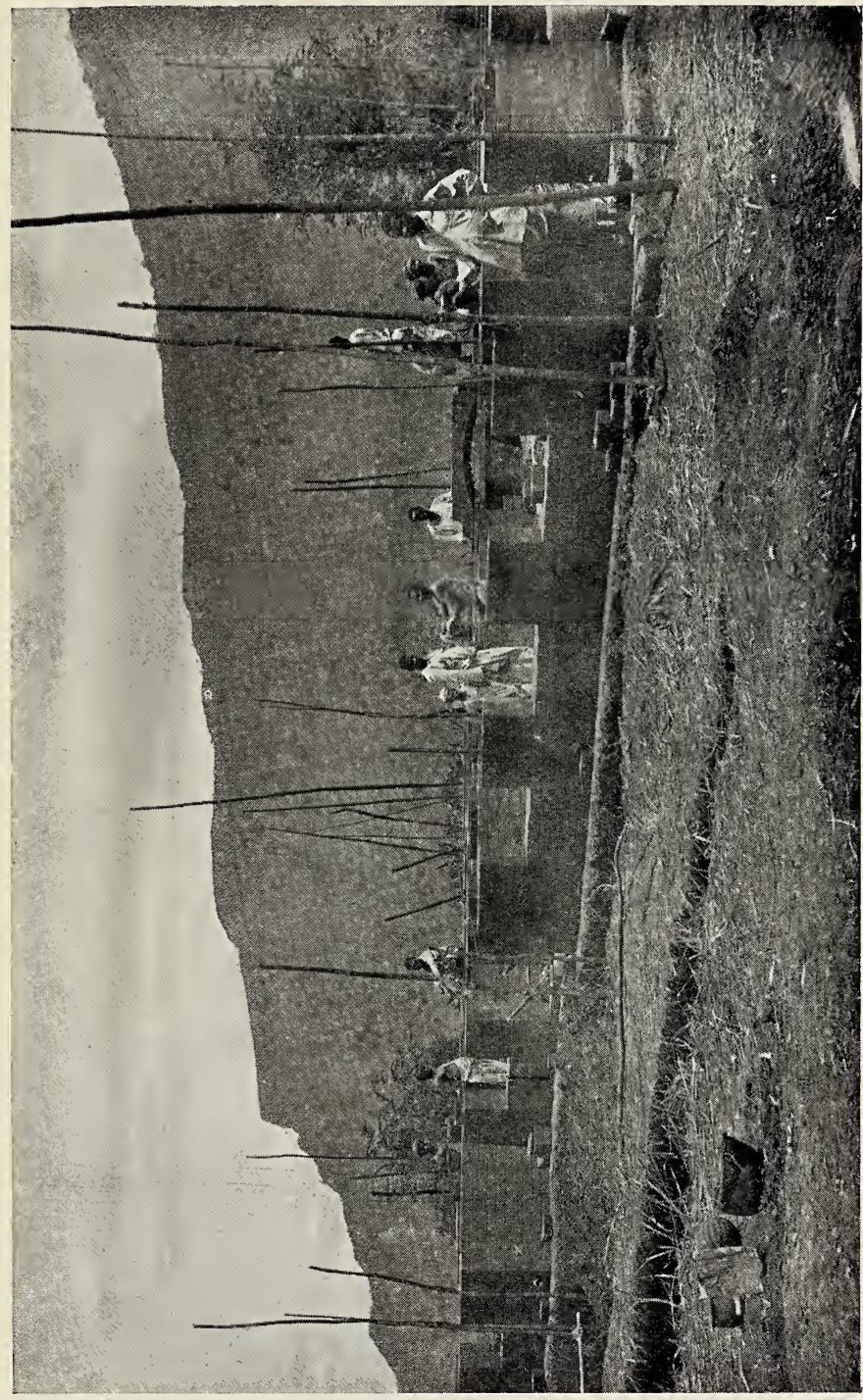

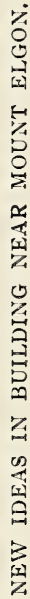





\section{True Gentility}

pean ladies, and house for second European man.

All this entailed a feature quite novel to the life and custom of Masaba-persistent, consecutive work; and I was repeatedly warned that to try and get the clans to work together was to attempt the impossible. However, I attempted it with the most gratifying results, for as soon as they realised that $I$ was not there to force them to work, and would pay them for their labour, hundreds came with poles and wattles, fibre for thatching, to stamp mud for walls, to carry stones for foundations, to build a house in the hills, to go with me on the march whenever necessary; and when the first brick house was built, some three hundred Bagishu went to Jinja, a distance of a hundred miles, with a native headman, and brought the corrugated iron for the roof.

All this time we were making friends with the people, and many evidences of friendship they gave us. I well remember how, on one occasion, when, because of a long drought, famine was sore in the land, and our native teachers and house-boys were wondering what they would eat, a native chief-head of his family-Wanyonyobolo by name, marched up to our house, followed by more than a hundred 


\section{Io Uganda to Mount Elgon}

people, each one carrying a small basket filled with peas and beans, which they had treasured up from the last harvest for such a time of need.

This raw native, with true gentlemanly instincts, quietly asked a boy where they could deposit their present, and having been told, they took themselves off, without even so much as "how do you do?" to the European.

This kindness was repeated again and again by people who knew that I had made a rule to send away again with their gifts those who came with ulterior motives.

It is said that the ulterior motive is never far from the African; well, perhaps not, but the present condition of European social amenities, such, for instance, as the close connection between a wedding invitation and a wedding present, or the quid pro quo now being demanded with loud-mouthed threats by the brewers from the bishops, prevent our throwing anything that might expose to attack our own glass houses.

The Church Missionary Society sets its face dead against the "no blanketi no Hallelujah" type of Christian, and the Bagishu of Masaba did not come to us for what they could get.

For some time we gathered a few people 


\section{A Unique Congregation 3 I I}

together daily in a small shed for instruction and worship, but this building was soon too small, and through the great kindness of our Bishop, Dr. Tucker, we erected a building to hold four hundred people.

The day appointed for the formal opening of this building was wet, cold, and dreary; but these wild, naked people crowded in from hill and dale, and must have presented a weird spectacle to their loving Bishop, who has always been much interested in Masaba, to the Venerable Archdeacon Walker, of Uganda, and to the Rev. T. R. Buckley, now Archdeacon of Usoga, who had cycled over to be with the Bishop and myself at the opening.

The building is so arranged that the men use one door and the women another. Two men are appointed as churchwardens, and they regulate the incoming and outgoing of the people: All spears, knives, sticks, and pipes are given up at the door and returned at the close of the service.

On the day of the opening the wardens refused to take responsibility for sticks, so great was the crowd, and I well remember the amazement of the Bishop at the pile of sticks outside the church door, and the wonderfully good-natured scramble for them at the close of the service. From that day a short ser- 


\section{Uganda to Mount Elgon}

vice has been held each morning in the building, and daily morning and afternoon school at which reading, writing, arithmetic, singing, and sewing has been taught.

For nearly two years my wife and I were alone, but the demands of the school, dispensary, visiting, building, and language work became very heavy, and a European lady, Miss Pilgrim, a qualified nurse, sensible woman and true missionary, was sent to help us.

It is almost if not wholly impossible for people at home to realise the variety of work one may be called upon to perform at such a station. Imagine a clergyman at home being called upon at the close of the morning's service to perform an operation on a youth whose head had been terribly mauled by a leopard, summoned from lunch to amputate a finger, or hauled out of bed at night to stop a fight and dress the wounded!

The most interesting surgical cases are brought to one's notice in such a country, and I should like to mention one of special note. A man who joined with others in some attack was speared in the abdomen and carried home, presumably to die. After some days I was asked to visit him, and found that his bowel was pierced. I had him brought to the dispensary, where the wound was cleansed 


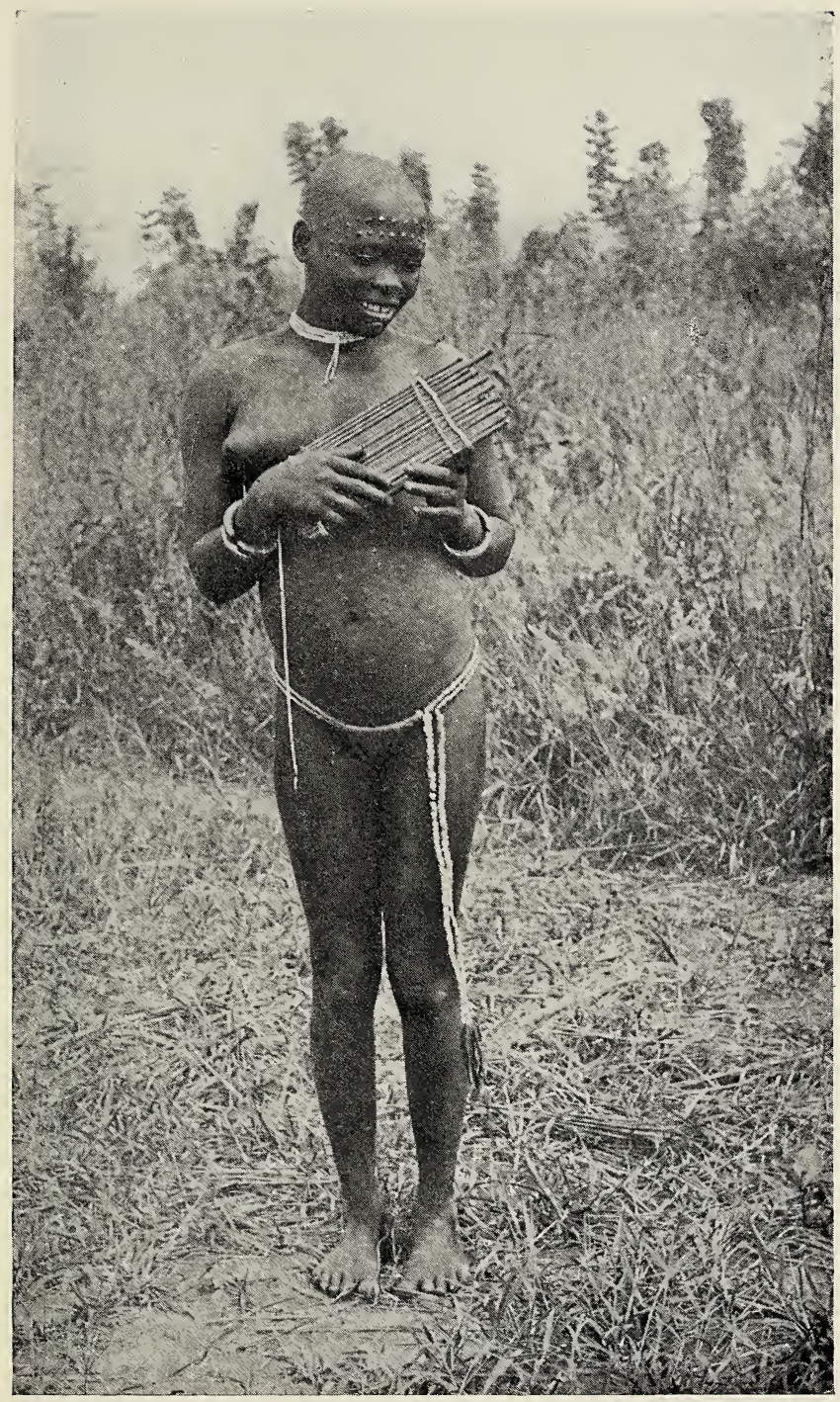

A MUGISHU GIRL HARPIST. 



\section{Natural Surgery}

from what appeared to be a filthy application of native herbs and cowdung; the nurse also verified the diagnosis that the bowel was perforated, and the man said he knew it was so, and was careful as to what he ate. The case was hopeless from our point of view, and we told him so, but expressed our willingness to do all we could for him. He expressed his gratitude, but said he would go on with the native medicine, and we were positively amazed to find that he got gradually better, and is now quite well.

After seeing such a case, one is tempted to ask, Why is it that we Westerns have been civilised beyond such powers of natural healing?

The dispensary and school work continued to grow, and two more missionaries were added to our staff-a lady from Australia, Miss McNamara, and Mr. Walter Holden, from England.

My own time was now taken up with language work, building, and occasionally visiting other parts of my district. A temporary church, used also as a girls' school, a boys' school, a house for teachers and boarders, a brick dispensary, a brick house with corrugated iron roof for the missionary in charge, and a brick house for a second man were completed. A brick house for ladies was built 


\section{Uganda to Mount Elgon}

to the top of the windows, a site prepared for the permanent brick church, a football ground cleared, and on Christmas Day, 1906, I had the unspeakable pleasure of baptizing the first Bagishu, and of receiving them into the visible Church of Christ. 


\section{CHAPTER XV}

\section{LANGUAGE DIFFICULTIES}

Preliminary difficulties-Publication of the Lumasaba Grammar -A primitive language-Legend about Victoria Nyanza Bantu group-Comparative study advised-Bantu language characteristics-Confusing similarity in Luganda-Perfect grammatical construction-Rich vocabulary-How to express abstract ideas-A faithful lad-A prayer- and hymnbook-Idiomatic phrases-Politeness.

THHERE were many difficulties to contend 1 with that at first sight seemed to me insurmountable, and the greatest of them was the language.

Mr. Crabtree, a recognised linguist, was unable to help me as he would have desired, but he placed at my disposal what little he had done in Lugishu, and with this help I was content to go on until a lull in building operations, the advent of new missionaries, and my own ear told me I must go deeper into linguistic matters. 


\section{I 8 Uganda to Mount Elgon}

In the country of Uganda such a desire for knowledge has only to be expressed by the new-comer from Europe to receive every encouragement from the people. Careful, kindly, polite, and able, the Uganda man or woman will answer questions and guide one over pitfalls. How different in the country of Masaba! Almost every question was answered by a look of amazement, as much as to say, "What in the world is he after?" or a loud guffaw of laughter, as if they much enjoyed my endeavour to be funny.

Yet they were not slow to protest most vigorously against the translations used. On one occasion an indignation meeting was held and a protest was sent to me against reading a certain word in church, and a plain intimation that if it continued the women would not attend.

I called the people together, told them how anxious I was to use correct words, but unless they helped me by answering questions whenever I asked for meanings, names, \&c., I could not get on.

From that time I had less difficulty, and worked continuously at the compilation of a dictionary and the general construction of the language. 


\section{A Lumasaba Grammar 3 39}

Any one will understand something of the difficulties one had to contend with in trying to master the details of grammar in a language not hitherto reduced; but every one conversant with the construction of Bantu languages will understand that since Lumasaba is a Bantu tongue, I had some general rules to go upon.

I completed the Lumasaba Grammar in Holy Week, 1907, and at the end of the same year the work was published by that great Missionary Society of the English Church known as the S.P.C.K. (Society for Promoting Christian Knowledge).

In the Introduction to that work I say, "There seems little doubt but that in the country of Masaba, i.e., the land on and near Mount Elgon, we have the most primitive language of what might well be called the Victoria Nyanza Bantu group."

There is undoubtedly something more than legend in the story that long, long ago a vast body of people, probably Gallas,* led by two brothers, came from the east and settled for a time at Masaba. Here they discussed the direction of their further wanderings, and it was finally decided to go off north-east.

* A. . Keane's " Ethnology," second edition. 


\section{Uganda to Mount Elgon}

At Bugondo, a large hill in the Teso country, overlooking Lake Kyoga, and from which can be seen the countries of Usoga, Unyoro, and Uganda, there are pits pointed out from which the natives declare these early wanderers quarried the ore with which to provide iron for their weapons.

After a stay at Bugondo it was agreed to separate. The elder brother, Lukidi, crossed Lake Kyoga and took possession of Unyoro, while Kintu crossed to Usoga, where he settled his nephew, and then went on to Uganda, where his name is still well known in connection with legends dealing with the beginning of things in that country.

Probably large numbers of the Negroid natives of Masaba joined the Hamitic invaders and went off with them westward, whilst other Bantu Negroids are said to have gone off independently toward the south, settling throughout Kavirondo and still farther on; and some few more daring spirits are accredited with having crossed the Lake Victoria to Uganda.

Certain it is, there seems a wonderful relationship, which can scarcely be wholly due to the similarity of construction that exists in all Bantu tongues, between Lumasaba, Lukavirondo, and Lusukuma towards the south, and 


\section{Perfect Classification}

betwoeen Lumasaba and Lugwere (old Lusoga), Lunyoro, and Luganda.

It remains but to compare the dialects spoken in the districts of Ketosh, Bunyuli, Bugwere, Bulamogi, and South-east Kyagwe, North Bulondaganyi, and the shores of Lake Kyoga, to find the stages of transition.

Such a comparative study would, I am certain, well repay the effort; but $I$ can refer to it only incidentally, in order to make known a striking peculiarity in Lumasaba.

Learners are always reminded the "one characteristic of Bantu grammatical structure is that nouns have prefixes according to classes." As the languages of the Victoria Nyanza Bantu group are at present used, this is not strictly correct, for no learner can possibly differentiate by the class prefix the singular of Class $I$. from the singular of Class II., or the plural of Class III. from the singular of the same class, or the plural of Class VI. from the plural of Class III.; and it is not until the pronominal concords are known that nouns can be correctly classified.

This confusing similarity in substantival class forms, but clear differentiation of classes in pronominal agreements, is a real difficulty to one trying to learn Luganda, for the noun is often represented pronominally by a 


\section{Uganda to Mount Elgon}

form quite foreign to the known substantival form, e.g. :-

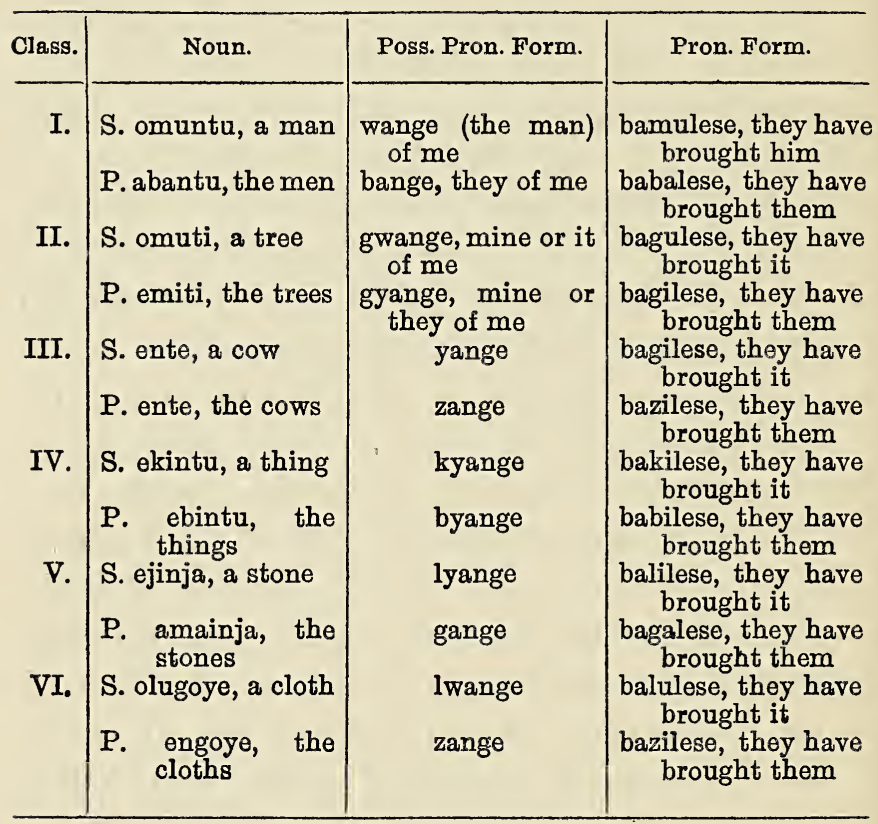

So far as I am aware, no hint has ever been given as to why, to take one case only, the pronominal forms of Class II. should be "gu" and "gi"; and, bearing in mind the difficulty to account for the initial vowel, I have dared to think that the substantival class forms found in the Victoria Nyanza Bantu group are not 


\section{Lumasaba Class Forms 323}

now in their original perfect forms; and, as evidence in favour of this opinion, I most respectfully ask the attention of all interested in "Bantu" to the class forms used by these primitive mountain people, the Bagishu, or Bamasaba :-

\begin{tabular}{|c|c|c|c|}
\hline Class. & Noun. & Poss. Pron. Form. & Pron. Form. \\
\hline $\begin{array}{l}\text { I. } \\
\text { II. } \\
\text { III. } \\
\text { IV. } \\
\text { V. } \\
\text { VI. }\end{array}$ & $\begin{array}{l}\text { S. umundu, a man } \\
\text { P. babandu } \\
\text { S. kumubano, a knife } \\
\text { P. kimibano } \\
\text { S. ingafu, a cow } \\
\text { P. tsingafu } \\
\text { S. kikindu, a thing } \\
\text { P. bibindu } \\
\text { S. libali, a stone } \\
\text { P. kamabali } \\
\text { S. lugoye, a piece } \\
\text { P. of bark }\end{array}$ & $\begin{array}{l}\text { wase } \\
\text { base } \\
\text { kwase } \\
\text { kyase } \\
\text { yase } \\
\text { tsase } \\
\text { kyase } \\
\text { byase } \\
\text { lyase } \\
\text { kase } \\
\text { lwase } \\
\text { tsase }\end{array}$ & $\begin{array}{l}\text { bamurerere } \\
\text { babarerere } \\
\text { bakurerere } \\
\text { kakirerere } \\
\text { bakirerere } \\
\text { batsirerere } \\
\text { bakirerere } \\
\text { babirerere } \\
\text { balirerere } \\
\text { bakarerere } \\
\text { balurerere } \\
\text { batsirerere }\end{array}$ \\
\hline
\end{tabular}

I have purposely chosen for comparison the first six classes only, because the remaining classes are subordinate; but these are sufficient to show the enormous value to the Lumasaba language of the prefixes, not found in this complete form, so far as I can find in any other Bantu tongue.

The question as to whether the more perfect class forms found at Masaba are more primitive than those used by kindred peoples, is still an 


\section{Uganda to Mount Elgon}

open one; but to me it seems hardly likely that the Masaba language has developed whilst the customs, manners, and general surroundings of the people have remained stationary.

The perfectly regulated grammatical construction of the Lumasaba language was a revelation to me, as was also their comparatively rich vocabulary.

I have been able to compile a dictionary of some ten thousand words, and although with this number it is quite possible to understand and be understood, yet it forms but a portion of the native vocabulary.

There is an almost total lack of words which we Europeans use to express abstract ideas, and in missionary work this lack is very much felt. Such ideas as love, grace, faith, trust, holiness, \&c., are quite unknown; and it is necessary to take other words, commonly used for the nearest equivalent meanings, and read and teach into them the fuller, deeper meanings.

If "love" exists, it is not expressed, and the Bagishu will only learn to express it by reading the deeper meaning into the word "Kugana" (want).

"Holiness" is quite unknown in reality or as an idea, but it is remarkable how quickly they grasp the idea of holiness, and the appropriate- 


\section{Evolving Abstract Ideas 325}

ness of using the word "Kikosefu" (cleanness or whiteness) to express it.

"Faith" is expressed by the word "Kufukirira," which means "to agree to,". whilst the deeper meanings of "grace" will be given to the word used to express "good-nature."

Many other words were equally difficult but more amusing to locate.

For months I was endeavouring to get the Lugishu equivalent for the English word hypocrite, and was met on nearly every hand with the statement that a person possessing such properties as we think go to make a hypocrite is a liar-a truth indeed!

The adjective mad conveys all the Bagishu wish to say about a person of constantly changeful mind; and in answer to the question of what they call a person who cannot come to a definite conclusion upon a subject, I was informed that they had no people of that kind in their country; and $I$ quite believe it.

Having solved some grammar rules, I was able, with the help of a Mugishu lad, Polo, who was afterwards baptized Andrew, to prepare a small reading-book which enjoys the title "Bimanyisa Kusoma" (the things which cause to know how to read). It opens with letters in Roman character, script and ordinary, small and capital; 


\section{Uganda to Mount Elgon}

figures, syllables, words, sentences, prayers, Creed, Commandments, texts of Scripture, the copy of a written letter, and a multiplication table.

Such a little book is of very great help in trying to teach these people, and it is not a little amusing to receive, most carefully folded, a piece of old newspaper, upon which is written an exact copy of the letter set at the end of the book:-

MASABa, Julai 20, 1907.

Ibaruwa ya Nayu.

Nakuchyesere lugali mulebe wase: Wena? ugona oryena? Ne bimutsu barye? Ubambonere bosi, ni babolera ngana kubabona wangu. Byaweye.

Ise wakyo,

NaYu.

\section{Translation.}

The letter of What's-his-name.

I salute you very much, my brother : How are you? How have you slept? And how are all in the house? See them all for me, and tell them I wish to see them soon. The (words) are finished.

I am yours,

WHAT'S-HIS-NAME.

The youngsters are fairly quick to learn, and quite a large number are now able to read 


\section{A Native Prayer Book 327}

a small catechism called "Katabo Kanyoherwako," i.e., the first book, which is used to teach them elementary religious truths.

One has also been able to translate Morning and Evening Prayer, The Litany, Baptism Service, Church Catechism, Confirmation Service, and various hymns. From these the S.P.C.K. have published what is called

\section{KULOMBA}

\section{KWIKUMUTIKINYI NI KWIHANGOLOBE}

NU

\section{BAKIRI KUBATISIWA}

NI MU

BANA BAKECHE

NE

KULOMBA KWIMUBIRO BIKALI BITWERA

NE

TSINYIMBO TSIKUBOLERESA WERE

MU

BABANDU BOSI

(Service Book, Hymns, and Occasional Prayers in Lumasaba.) 


\section{Uganda to Mount Elgon}

In mission work of this kind there are many discouragements; but any man would feel more than repaid to know that a people who answer almost exactly to Dr. F. C. Shrubsall's description given in the Lancet for April, 1908, of the Bushmen Hottentots, "They are said to have greater powers than the average of twisting their bolas and to practise sitting down and shooting poisoned arrows at one another. . . Their habitations were caverns, rock-shelters, or merely mats spread over branches. .. . They slept coiled up. ... They wore little clothing, and adorned themselves with necklets of beads made from the shells of ostrich eggs," can meet together and evidently enjoy the using of prayers and the singing of hymns such as we in England know so well.

"Papa wefwe ali mu igulu, Lisinalyo likosewe. Bubwakabakabwo bwitse. Byogana babikole mu kyalo, nga nibabikola mu igulu. Ukuhe kya lero biryo byefwe bya kifuku, Ukuyakire kukwonaga kwefwe, ngefwe bwekubayakira bakwonaga Ukakuhira mu bukongeresi, ne ukuhonese mu bubi. Kubanga bubwakabaka, ni bunyala, ni kitifwa, nibyo byowo, biro ni biro. Amina."

is the Lord's Prayer in Lumasaba, whilst the following are verses translated from wellknown hymns :- 


\section{Well-known Hymns}

Onward, Christian Soldiers.

"Babana ba Yesu mwinyuke mwesi !

Mulole Yesu, uyu warangiye:

Mu basiku bosi Yesu ufura;

Nakulanga Umwami; kutsye naye.

Babana ba Yesu, mwinyuke mwesi,

Mulole Yesu, uyu warangiye."

For My Satie and the Gospel's.

"Kulwase ni Kalwenjixi

Mutsiye bana base:

Nibiramu "Hakutsiye;

Kitifwa kibe kyuli."

Itsa kufira babandu,

Papa we nga muruma:

Wamalaho bibi byefwe,

Iwe kufwa hukisina."

Rock of Ages.

"Lurale lwikale iwe

Lwitikira kulwase

Muchi mwenibisira

Mafugike ichikama.

Bibi byosi binduseko,

Mbonesa mu mani kabyo."

That the language is fairly rich in idiom may be gathered from the following examples of how the question "Why?" may be asked :-

Kikulobeye Kukwitsa kina ?-Why did you refuse to come ?

Kina kigirire wala kwitsa?--Why did you not come? 


\section{Uganda to Mount Elgon}

Kina kigira ukatsya ?-Why have you not gone ?

Kina kigira akagobola ?-Why is he not returned?

Kina kigirire balaire kugobola?-Why have they not returned?

Kina kyagira bala kugobola? - Why did they not return?

Kina kikukingiriye kukwitsa wangu ?-Why did you not come at once?

Kina kigira ukateka?-Why do you refuse to cook ?

Kina kigirire walahakuteka?-Why have you not cooked?

Kina kikukolesere kiri? -What causes you to act thus?

Kikukolesere kiryo kina?-Why did you do this or that?

Ukolere kina oryo ?-Why have you done thus ?

Wakola kina oryo ?-Why did you do thus ?

Kina kigira ukola oryo? or Kigira ukola oryo kina?-Why are you doing thus?

Urerere kametsi ka ki ?-Why have you brought the water?

Kikurerere kina?-Why have you come? (Lit., What has brought you ?)

Loma kigirire ukola oryo?-Give the reason why you act thus?

The language reveals to us that even these primitive people know how to be polite, and a stranger will do fairly well among them if he learns nothing more than a few salutations. Certain of these are used irrespective of time, such as "Mulembe? or Mirembe?-Peace."

Ans. Mulembe-Peace.

Ques. Ulame?-A very old form. Probably means "Are you there?"

Ans. Ulame. 


\section{Lumasaba Salutations}

Ques. Wena? Are you well?

Ans. Wena? Are you well?

\section{Morning Salutations.}

Wagonere oryena?-How have you slept?

Nagonere bulahi? Njebewe?-I have slept well. Perhaps you? i.e., How about yourself?

Bengo baryena?-How are those at home?

Baliyo balwakire.-They are well. How are you?

\section{Afternoon Salutations.}

Wabuyire oryena? - How have you passed the day?

Nabuyire bulahi. Njebewe ?-I have passed it well. Perhaps you?

If the person addressed is ill he uses the word nindwala-I am ill-instead of bulahi.

There is no exact equivalent for our Goodbye. The departing guest says Nitsya-I am going; to which is often added the wish Nule, or Nule bulahi-May I reach, or May I reach safely.

Nutsye wule bulahi.-Go, may you reach safely. Nule bulahi.-May I reach safely.

Nutsye ugona bulahi.-May you go and sleep well.

Ngone bulahi.-May I sleep well.

My great hope was to translate the Scriptures, but such a work was not to be begun until the details and scope of the language had been mastered. With the Grammar and Dictionary 


\section{Uganda to Mount Elgon}

completed, the way seemed open for the contemplation of the greater work; but evidently it had not to be, for doctor's orders are imperative, and one can only live in hope that another opportunity for this work will be given. 



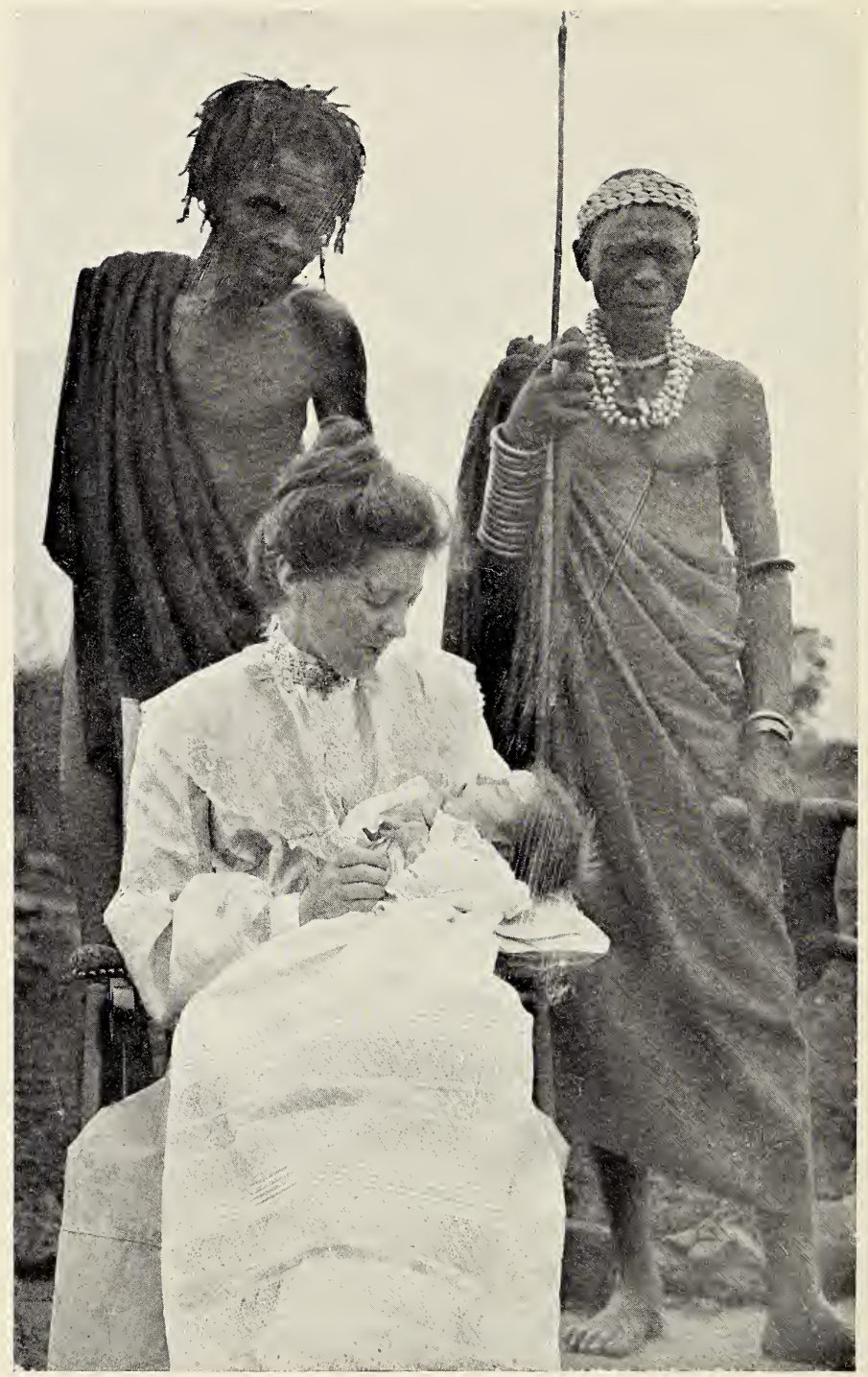

VISITORS TO THE YOUNG WHITE CHIEF. 


\section{CHAPTER XVI}

\section{LIGHT AND SHADE}

Slow progress-Friendly and trustful natives--Spirit of independence-Indian hemp-smoking-Effect of evil practices -Native dances-Drink and fighting-Wailing-Native industry-Lighthearted geniality-Witchcraft-The power of suggestion-Protection against witchcraft-No God of love in Masaba-Evil spirits-Altars and offeringsSacrifices-Sacred groves-A liking for football-Ghoulish practices-A low standard of civilisation-Compensations -Native ability-Open doors.

W ${ }^{\text {ITH buildings, books, and additional staff }}$ the work is more definitely organised, hopeful, and interesting; but Masaba is one of those mission fields where mental, moral, and spiritual progress will be slow. The habits and customs of past generations will not be lightly cast off, and loving patience will be necessary to hold the people until they understand, appreciate, and accept the structure you are trying to erect to some extent on the foundation of belief already found among them. 


\section{Uganda to Mount Elgon}

One of the greatest pleasures of life at Masaba has been the perfectly friendly and trustful manner of the natives towards us at all times; and this attitude is one to be encouraged and reciprocated whether the people attend church and school or not, for it enables the missionary to get to the back of the native mind-to know something of their beliefs and unbeliefs, strength and weakness, likes and dislikes, hopes and fears. It will also enable him to do his work and limit his expectations according to the character of the people, rather than according to preconceived ideas gathered in a country such as Uganda, where the history of the people and the circumstances of life are totally different.

Here there is no king or feudal chief to influence his followers one way or the other. Every man, woman, and child claims to be independent, and we often see the effect of this independence on our school children.

Probably through some early Arab traveller, the Indian hemp plant has been introduced into Masaba, and is cultivated by almost every householder, then gathered, dried, and smoked through a very primitive hubble-bubble pipe, made from a hollowed gourd which contains the water.

As a rule the adults are temperate in the use of the weed : a man will even forbid his wife to smoke it on account of some evil effect it is said 


\section{Evil Practices}

to have upon her or her child, should she be about to become a mother; but father and mother are quite careless about their children smoking it: for are not the children themselves responsible for their habits?

I have heard and seen the effect of this "bhang" smoking on porters from the coast, and thought it dangerous enough in the case of strong men, but when I saw its effect upon the Bagishu children I was appalled.

The brightest little boys and girls have attended our classes and made remarkable progress for a time; then suddenly lost their brightness, interest, health, and intelligence. At first this puzzled me; but there is little doubt but that it is due to the smoking of hemp, or, as the natives put it, to the drinking of "itsayi," since the act of smoking can only be described by the native as drinking.

Contributory causes to this dulness are sexual connection among the young and drinking the native strong drink, though the latter is not often indulged in by children.

It seems incomprehensible that a people so strict at certain times about the purity of their girls, that a girl pregnant before marriage is punished, and a girl suffering from specific disease becomes an outcast, should at other times encourage them in what they pronounce wrong- 


\section{$33^{8}$ Uganda to Mount Elgon}

doing. Yet the heads of families actually do this by holding at certain seasons of the year what they call an "ingoma," i.e., an all-night orgy, to which all young people of other clans are invited by the beating of a peculiar long drum known as an ingoma.

These festivals are generally held about the time of full moon, and sometimes go on night after night. Undoubtedly the idea is to pair off the young people and to fix up engagements.

The Bagishu are passionately fond of dancing, and crowd to these "ingomas" for the professedly innocent as well as the wrong sport to be obtained.

Dancing plays an important part in their lives, for at marriage and death, to mark sorrow and joy, they dance until they are ready to drop from fatigue.

Intoxicating drink, too, is a source of great evil in the country, for it is used to mark every event in life. Births, deaths, marriages, preparing the land and gathering the harvest, before a fight and after a fight, are all opportunities upon which recourse is had to one or other of the native drinks.

The drinks native to the country are "indali inyana," an unfermented drink made from sweet bananas only; a fermented drink, "indali indule," made from sweet bananas and fermented with 


\section{Refreshing Candour}

millet seed; and another fermented drink, "busera," made from two kinds of millet seed.

I have said that dancing plays an important part in the lives of the Bagishu; well, even dancing loses its relish if drink is absent.

There are private drinks, clan drinks, cultivation drinks, wedding drinks-the people of Mabasa have not yet reached the stage so prevalent in England of serving out intoxicating liquors at funerals-circumcision drinks, and drinks indulged in to prepare the warriors for a fight; a real fight I mean, not a political election.

The candour with which the Bagishu announced their drinking proclivities was at first rather a shock, but after all was so unusual that it proved refreshing. Building operations had been going on for some time at the mission station, and I anticipated a successful and hasty conclusion, when some of the elders approached me and said they were going off for at least two weeks to drink, and I must get on as best I could without them. No humbug about them in that matter at any rate, and I found them much the same if an individual was missing from work, school, or church at any time. They did not say he had gone into the country, or had a sudden attack of illness; they said he was at home or elsewhere drinking. 


\section{Uganda to Mount Elgon}

The effect of hard drinking is as evident among the adults as that of hemp-smoking is among the young. Some of them are in a constant state of drivelling inebriation, whilst others become cantankerous and quarrelsome.

A foolish word of boasting or contempt spoken at a drinking party has led to many a quarrel with serious results; and one such termination happened soon after our arrival at Masaba. A company of men were drinking not far from our station, and one of the visitors had spoken disrespectfully of his hosts. He realised his mistake and made tracks for home as hard as he could go followed by about half a dozen young fellows each armed, like himself, with a long, business-like stick. They caught him as he passed our door, and but for our instant intervention he would undoubtedly have been killed. As it was I had to bind up his frightfully cut and bruised head and shoulders, his assailants looking on muchly interested but crestfallen.

On another occasion my wife and I were at the rest-house in the hills. The men of a neighbouring village had been up the mountain to a large drinking party, and on their return I had some conversation with them and found that some argument was being continued. This led to a quarrel when they reached home, 


\section{A Fatal Argument 34 I}

and we were not surprised to see some of the houses of the village go up in flames. It was, however, rather disconcerting to know that the quarrel had become a general fight, and it was something of a shock to me next morning, on my going down to see if any required their wounds dressed, to find one fine young fellow lying dead. In the heat of the argument he had given his companion the lie, and the other had promptly rammed a spear down his throat.

As is always the case, the murderer had fled with his nearest male relatives, and men and women had gathered near the corpse to dance the death dance-a weird sight and sound, for the men as a rule dress in war attire and with iron bells fastened just below the knee dance to the rhythm of the sound, whilst the women with their string dress hanging down loose behind, dance near the men but not with them, and add to the weirdness of the occasion by wailing at regular intervals.

This ceremony is performed with the idea of giving honour to the spirit as it enters "Makombe," the spirit-world.

We must not run away with the idea that the people of Masaba do nothing but drink and fight, for one is amazed at the little harm they do each other, and at the amount of 


\section{Uganda to Mount Elgon}

industry that might be turned into channels more profitable to the people and the country.

The native blacksmiths are men who work with the most elementary tools it is possible to conceive : a stone for an anvil, and another for a hammer, yet their work will certainly bear inspection.

The houses are better than the houses of Usoga, and indeed superior to the houses that have, until this last year or two, satisfied the peasant of Uganda.

It is remarkable too that in Masaba the men help to cultivate; indeed, they are primarily responsible for the cultivation of all cereals whilst the women are responsible for the plantain groves.

There is a charming lightheartedness, breezy geniality, and kind good-nature about the Mugishu that reminds one of Ireland; and when prospects are darkest keep one hopeful.

The crowds that came from far and near to listen to the gramophone-or at other times to see and play with the little white boys until the baby or his father would produce a doll, when off they would scamper with shrieks of wonder and fear real and feigned-were always good-natured crowds, ready to do anything for the white babies or their mother. These visits enabled us to get a little insight 


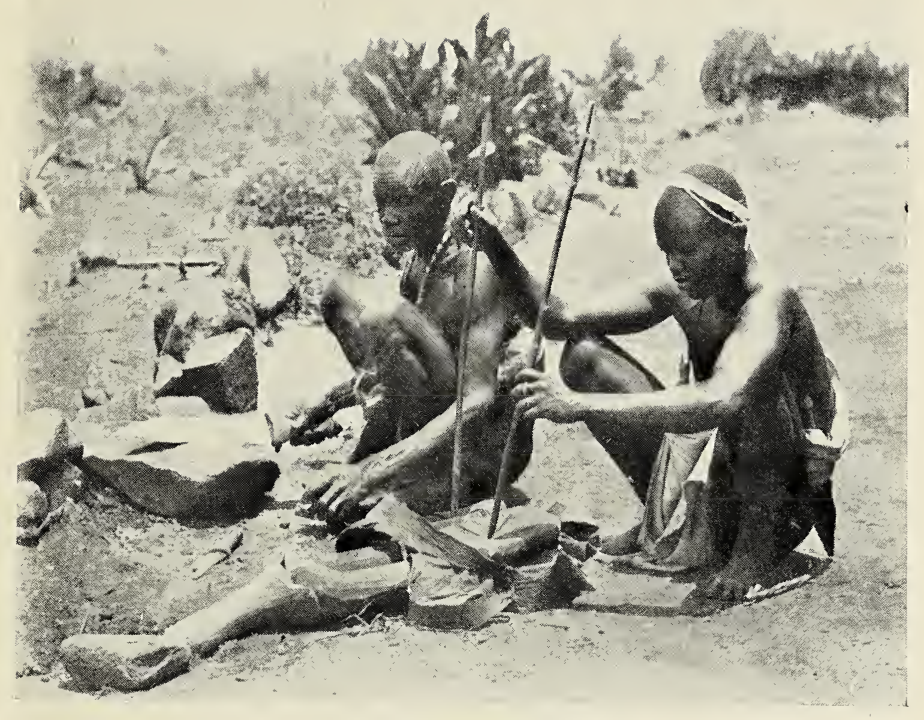

BAGISHU BLACKSMITHS. 



\section{The Power of Witchcraft 345}

into their inmost thoughts, and showed us something of their terribly strong belief in the power of witchcraft and the evil eye, for not only were the visitors themselves sometimes frightened by the children's dolls or mechanical toys, but men have again and again come to ask for the loan of a doll with which they wished to bewitch some opponent or other.

This belief in witchcraft is one of the greatest and most dangerous powers in the land, and is sometimes responsible for most terrible consequences.

One such case came under my notice not long ago. My wife and I were visiting a native village and saw a young woman of fine physique, known to us, leaning listlessly against a grain store. I suggested her doing some work, but her answer was that she was seriously ill. I told her she did not look ill, and that perhaps a little work would put her right; but the chief and other people came near and assured me that she was seriously ill, having been bewitched. I begged for an explanation, and they told me that some little time before my visit the girl and others were playing, when a man, well known to them all, ran off with her beads, kept them for some time, and then returned them to the girl, who put them on and immediately believed herself bewitched. From that 


\section{Uganda to Mount Elgon}

moment she declared herself unable to work, and no amount of argument, ridicule, or expostulation availed to shake the foolish belief of herself and people. Her mind was fixed, her body gradually but somewhat rapidly gave way and she died, whereupon a solemn meeting of the clan was called to try the case: witnesses gave evidence against the man, who was declared guilty of witcheraft and straightway beaten to death.

There was no attempt on the part of the clan to shirk responsibility for his death. I understand the matter was reported to the Government officer, who sent for the man really responsible for this judicial murder, and he went immediately, declared his responsibility, as head of that portion of the clan, and justified his action by native custom.

I do not suppose that even so-called Christian Scientists can give us a more striking example of the effect of mind over matter than the one just quoted; and there are many such in Masaba.

The people are often charging each other with witchcraft and the practice of the evil eye, and great care is taken to detect such people.

Every house is built with little spy-holes through which watchers look at night for any 


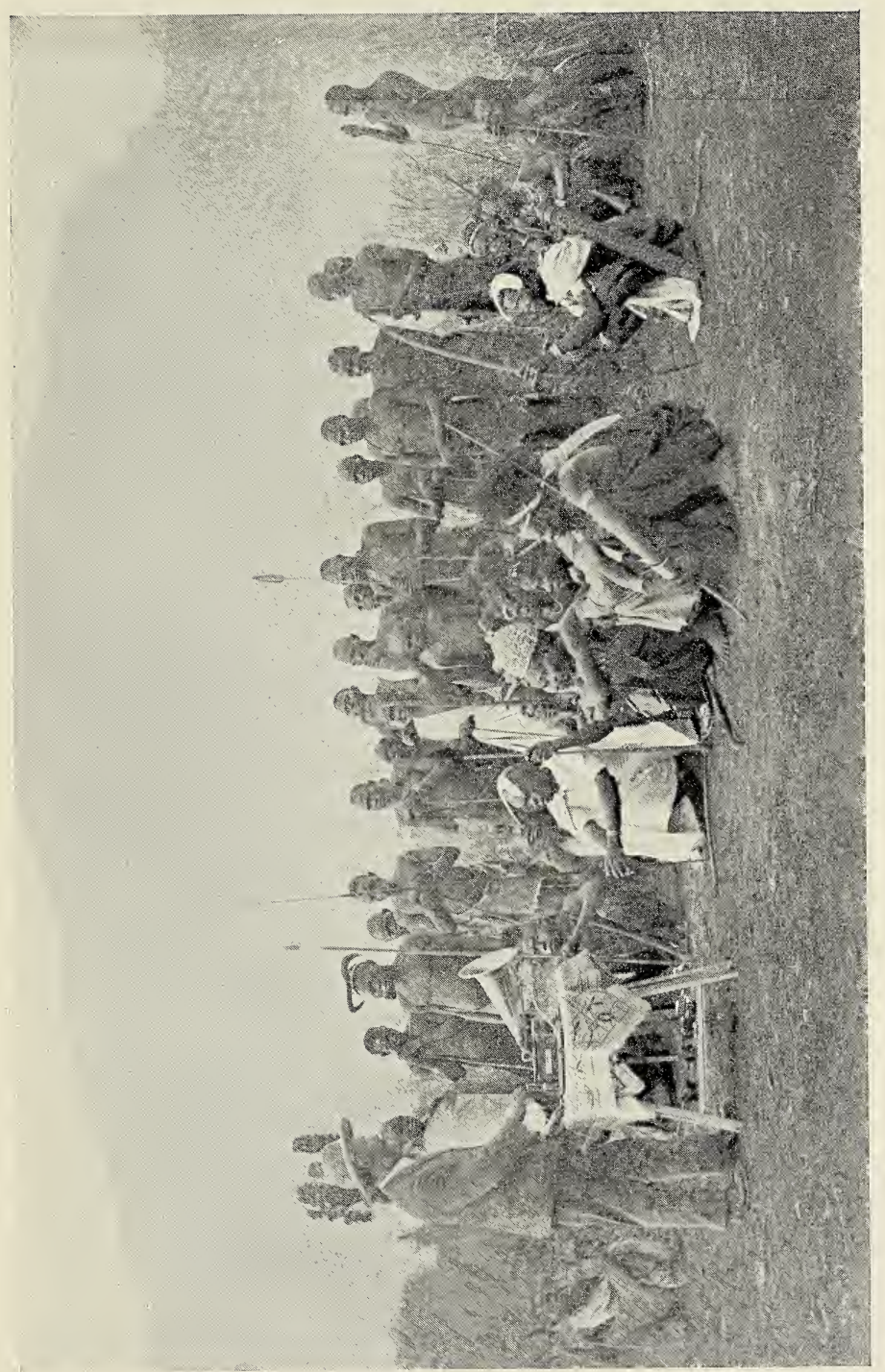

 



\section{An Amusing Episode}

enemy who may creep up and place a kumusala, that is, a piece of tree specially used by bewitchers, who place it outside the door of a house in such a way that a person coming out, unless very careful, is obliged to touch it. I need not say that the Bagishu are very careful as they come out of their houses in the early morning; and they are also careful to find out who travels about at night.

The fear of being charged with witchcraft is an effectual deterrent against late hours in Masaba, and the trial of culprits is indeed laughable were the consequences of an adverse verdict not so terrible.

Not long ago a clan met together to try $\mathbf{A}$ for witchcraft. He was not a favourite in the clan, and they were willing to grasp at any evidence against him. He was charged with being seen near a certain house late one night, and $B$, who was a great favourite, gave evidence that he saw A near the said house. When passing the assembled crowd I asked the reason for their being together, and the elders came and told me of A's guilt as proved by B. They looked very much surprised when I suggested that $B$ should be charged with witchcraft, for, on his own confession, he was near the said house at a wrong hour. In his case there was no doubt about it, but in A's case there was some question. 


\section{Uganda to Mount Elgon}

I knew that B was safe, but my suggestion doubled him up and he made for home amid the loud laughter of the assembly, which immediately congratulated $\mathbf{A}$ on his innocence.

A recent letter from Masaba says : "Only the other day some of the Bagishu went up the hill to burn down a medicine-man's house, because he had promised them rain, had taken their cattle, and had sent them only a terrible wind, which blew down their toki (plantain-trees)."

It is to be expected that such beliefs interfere very considerably with missionary effort, for although the Bagishu believe in Were, the Creator of all things, the Great Spirit, they think of Him as one to be greatly feared on account of His ability to do them harm; and almost their chief thought in life is how to appease Were and the many evil spirits known as Kimisambwa.

An altar is erected inside every house to the spirit responsible for the safe-keeping of houses; and upon it is placed food and drink offerings. Then just outside the door may be seen little altars built in the form of tiny houses, erected to the honour of various spirits responsible for health, weather, \&c.

When examining these shrines I have often reminded the people that they cannot think highly of the wisdom of these spirits when they 


\section{Sacrifices}

dare to eat the inside out of an egg and then place the shell in such a position that a casual onlooker might think it full.

There is no such thing as worship among the Bagishu of Masaba such as we understand it; but in times of sickness, famine, war, and pestilence sacrifices of goats and oxen are made to Were, and presents offered through the witchdoctors to the evil spirits.

In the case of sickness, the nearest relative of the sick person provides the offering, which is brought to the door of the house in which the sick person lies. This relative places his hand on the head of the offering and professedly gives it to Were. If the goat or ox micturates, the offering has been accepted, and there is great joy and hope; but if not, it is said that Were refuses the offering, and it is killed in gloom and despair.

The offering is cut up and distributed to the onlookers in the hope that any who may have bewitched the sick person will withdraw the evil influence. God and man, they hope, is thus appeased.

It behoves every member of the clan to attend these offerings, and also the dance performed after the death of a person, in order to remove any suspicion of having been concerned by witchcraft in the sickness or death. 


\section{Uganda to Mount Elgon}

There are also periodic processions to the sacred groves found on the land of each clan, when offerings are made by the witch-doctors to the evil spirits, much drink consumed, and licentious practices indulged in.

It may be difficult to credit that these men are good companions on the march, and delightful in the football field; yet such they are, and nothing appeals to them more than a good game of "Association," and even the little chaps will leave their imitation fights with bows, arrows, spears, and shields to learn all about "off-side," "corner," "throw in," \&c. In fact, their appetite for football is greater than we can satisfy, for the outer cases of footballs rot very quickly in the severe sun.

Europeans are always astonished at the way these "All blacks" can kick off the toe of a naked foot, and also at the sportsmanlike way in which they take a "charge" or a beating.

I have already referred to the custom of throwing out the dead practised at Masaba; and possibly this is responsible for, and not because of, the more loathsome custom of cannibalism.

No Mugishu will own that he is guilty of such a practice, but every one says that some one else does it.

Without doubt it is done and in a ghoulish 


\section{Cannibalism}

manner; for the dead are not always left to the hyænas. The natives suggest that it is only done in the case of bitter enemies at war with each other; but the more horrible practice of eating the corpse of a dead friend was once brought to my knowledge, and the only redeeming feature about it was that, when known, it caused bitter shame.

Sir H. H. Johnston was surely right-so far as some things are concerned-regarding their low standard of civilisation. A glimpse at some of the faces is enough to satisfy on that point, but the pleasure and satisfaction of helping them upward is all the greater; and to see a naked, wild, uncouth youth grow reasonable, kindly, thoughtful, and manly is worth a good deal more than a "go" of blackwater fever. This has been the case again and again in various parts of the Uganda Protectorate, due to the influence of the Gospel of Jesus Christ: and $I$ have reason to think it has been so, in a small measure, at Masaba, where the lad Polo, not beautiful to look at, but one of the best wrestlers in the country, stuck to me day after day and helped me with the language until I was invalided. He with others was baptized more than a year ago, and to-day he is a teacher in the boys' school at our central station in Masaba, and, if I mistake not, has with the help 


\section{Uganda to Mount Elgon}

of a European, been endeavouring to translate the Gospels.

On every hand there is evidence that a mission station has been a peace-factor and blessing to the district, for drinking and fighting went decidedly out of fashion; and my collection of curios prove that weapons of warfare have been given up for instruments of agriculture, one hoe for a spear, two for a knife, and from three to five for a shield.

Old beliefs and customs die hard, and no one outside Masaba can conceive what it means to have a hundred of these people under daily instruction, or a congregation of over two hundred at the central station on Sundays.

If one of these attenders fall sick, the outsiders tell him that we have bewitched him, or that Were has punished him for presuming to speak to Him as we do in our prayers.

Some of the Bagishu even come near the church to see what will happen to such audacious people as those who join us at worship; and some of the parents are so nervous that when the school drum sounds they drive their children into the bush to prevent their attending. A glimpse at some of the pictures will show, however, that this fear is not universal, for the tiniest little mites come and squat down at our door or in the school; 


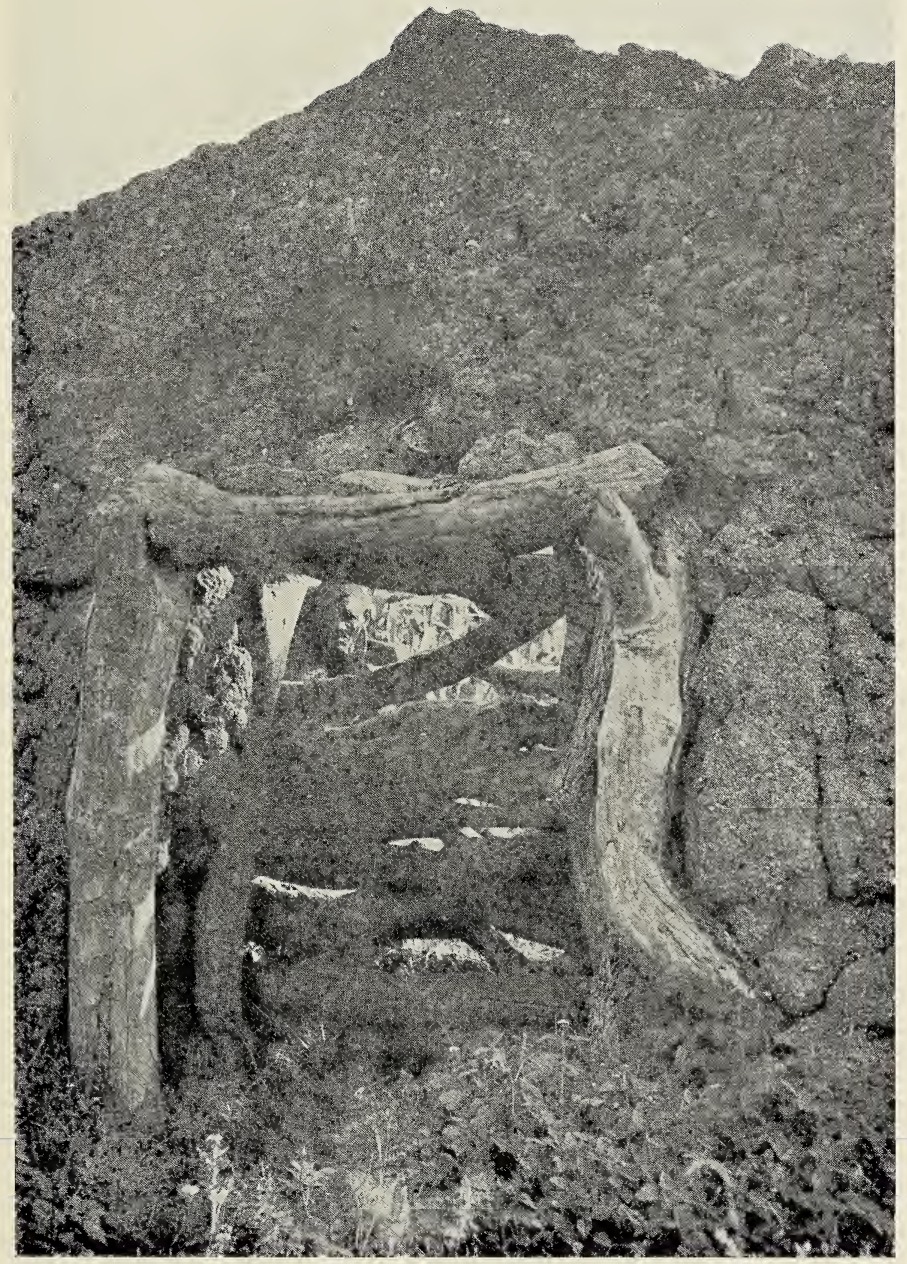

DOORS THAT ARE BEING OPENED. 



\section{Open Doors}

and for every childish ailment the help of the European is now sought and gladly given.

In the more distant fortified villages the doors have been opened to the missionary; and nearer home we organise sports as well as offer work to counteract the dangerous tendencies of a decidedly energetic people. 


\section{CHAPTER XVII}

\section{NATIONALISING AND DENATIONALISING THE NATIVE}

The unsettling of the native mind-Bringing them into lineA bad inheritance-Painful memories-The evils of armed agents and punitive expeditions-Improvements-Possibilities.

NE of the greatest difficulties that we have had to contend with in the work at Masaba was the unsettling of the native mind and mode of life by the incoming of Government administration.

In 1903 the actual work of dealing with the natives was done by the Muganda chief, Semei Kakungulu, who is now in Usoga. He had placed his agents in various parts of the country to rule it on lines similar to the feudal system of Uganda, and he was answerable for the general condition of the district to the British official at Budaka, situate some twenty miles from Masaba. 


\section{Bringing the Native into Line 359}

It was the express wish of the then Commissioner of Uganda that the raw natives in this eastern portion of his district should be "brought into line," as the expression goes, very gradually; and probably to make sure that the Muganda chief and his men played square with the native and the Government the official post was moved from Budaka to Mbale, a Uganda colony situate at the western side of the Elgon foothills, brought into existence by the dogged perseverance and hard work of the chief Kakungulu and his people.

New assistant collectors were appointed from time to time, and gradually a new order of things was evolved which brought the Baganda in outlying places directly under the control of the Government officer.

I am convinced that this step was taken for the good of the Bagishu; but after some four years' residence in the district $I$ am bound to say, having earnestly and carefully weighed the seriousness of the statement, that during the years of my residence which mark the introduction of law into Masaba there seems to me to have been less peace, less security of property, and more, very much more, bloodshed than during the period I lived there without direct British administration. The method of collect- 


\section{Uganda to Mount Elgon}

ing hut-tax inherited by each assistant collector -in every case a kindly man and a gentleman -was no doubt responsible to a great extent for the unsatisfactory condition of things; and the introduction of punitive expeditions as a means of meting out punishment did not tend to idealise British rule in the minds of the natives.

My memories of the troubles between the Administration and the people of Masaba are altogether painful, for in almost every instance my sympathies are with the native, as I am sure would be those of any man who had been asked by the men of a clan to beg back the women who had been taken prisoners; to console the relatives and friends of a dead woman whom they deposited at my door, and said to have been one of four, besides men, shot that day by the native police; and obliged to turn the vestry into a hospital for the wounded, shot by native hut-tax collectors and their men without any provocation whatever.

These armed Baganda hut-tax collectors, many of them of the very worst type, distributed throughout the district and working on the percentage system, could be no other than a menace to peace and prosperity; and I am firmly convinced that they and their methods were responsible for at least two of the troubles 


\section{Punitive Expeditions $3^{6} \mathbf{I}$}

for which the natives were punished by the expensive and deplorable method of a punitive -I had almost written primitive-expedition. The punitive expedition is one method of dealing with an uncivilised people, but I believe too much in British common sense to think that the general verdict will be that it is the only or even a commendable method. A hundred pounds' worth of rubber-trees sent to an erring clan, with a sensible man who could teach them how to plant and rear them, would do far more good to them and us than all the punitive expeditions in the world.

The system of hut-tax collection has been altered by the Administration, and for that we are deeply grateful, but hope the use of the gun will be absolutely forbidden except in cases of direst necessity for selfdefence. The darkness of such a people as the Bagishu of Masaba, Mount Elgon "savage and uncivilised," as they have been called, is great indeed, but they are capable of responding to gentle methods, and the dawn, though slight, is visible and hopeful. Shall we not encourage and strengthen the gentle methods, though slow and tedious, remembering the Luganda proverb quoted once before, "Akwata mpola atuka wala" 


\section{Uganda to Mount Elgon}

("He who goes slowly reaches far"), rather than seek by harsher methods to make haste in a direction the end of which can be none other than moral and physical desolation? 


\section{INDEX}

A

Abuketi and Agu, 250

Abyssinia, 91, 172, 217, 265

Acholi country and people, 86, 250

Aden, 22

Administration of Uganda, 151

Africa, 33

Africa, British East, 27, 28

Africa, West, 130

Africa, white man's, 39

African and Asiatic, 54

African Highlands, 40, 41, 45, 50

African, the, 45,46

Albert Edward Lake, 97

Albert Lake, 97, 260

Algerian Fathers, 180

Aloe plant, 34

Anglican renegades, 216

Anglo-African town, 43

Antelope, 37

Ants, 130

Apolo Kagwa, Sir, K.C.M.G., 158

Arab and African, 60

Arab houses, 24
Archdeacon Buckley, 228, 256

Archdeacon Walker, 144

Aryan and Negro interming. ling, 55

Asiatic element, 57

Athi plain, 64

Atoxyl, an, 108

B

Bagishu, 271

Bahuma, 140

Bamasaba, 271

Bantu Kavirondo, 64

Bantu language, 317

Bantu tribe, 38, 63, 64, 68, 271

Baptisms at Masaba, 316

Bari people, 86

Bark cloth, 137

Barrage across Ripon Falls, 109

Beaten track, the, 21

Bees, 130

Belgian Equatorial Africa, 27

Belief in witcheraft, 345

" Bhang " smoking, 337

Bishop Hannington, 144, 188, 228,239 
Bishop Tucker of Uganda, 146, 228

Bishop Tucker's Palace, 195

Blackwater fever, 131, 233, 353

Bombay, 55

Boyle, A., Esq., C.M.G., 231

British East Africa, 28, 40, 60, 91

British East Africa Company, 89, 146

British East African tribes, 60-79

British Equatorial Africa, 27

British route, 37

British shipowners, 22

British v. German enterprise, 22

Bruce, Colonel, 106

Buckley, Rev. T. R., 228, 256

Budaka, 358

Bukedi, 241

Bulemezi, 224

Bululu, 256

Buvuma Islands, 97

"Bwana Tayari," 165

\section{C}

Cannibals, 304, 352 "

Canoes, 94, 97

Cardinal Vaughan, 180

Castellani, Dr., 105

Cathedral, the English, 181

Cattle, 44

Central Province of Uganda, 232

Cereals, 44

Chamber of Commerce, 161

Chillies, 117
Christian Missions, 56

Church and State, 209

Church Missionary Society, 32,

$88,89,90,104,134,157,161$,

$176,179,188,234$

Church organisation, 212

Church uses and discipline, 214

Circumcision, 271

Civilisation, 31, 32

Climate, 33, 44, 87, 131

Cocoanut cultivation, 33, 34

Collection of taxes, 158, 360

Colonists' Association, 50

Colony of British East Africa, 44, 50, 53

Company, British East Africa, 89, 146

Competition evils, 53

Concubines, 31

Congo Free State, 233

Cook, Dr. A. R., 104, 132, 188, 190, 202

Cook, Dr. J. H., 104, 132，188, 202

Cotton cultivation, 33, 116

Cotton export, 117

Cotton ginning, 177

Crabtree, Mrs., 259, 298

Crabtree, Rev. W. A., 298, 317

Crocodile, 94

Cubitt, 231

Culex anopheles, 128

Customs of Bagishu, 265-293

D

Dak bungalows, 37

Danger of numbers, 198 


\section{Index}

Dangers of education, 204

David (Daudi), King of Uganda, 146, 154

Debasian, Mount, 249, 259

Denationalising the native, 358

Densham, Dr., 119, 188

Develop native responsibility, 211

De Winton, 188

Difficulties with Roman Catholics, 216

Discipline of Church members, 215

Discovery of Lake Victoria and source of Nile, 88

Diseases, 131

Disintegration, 57 .

Dobosa, 261

Dorobo people, 84

Drinks of Uganda, 140

Dug-out canoes, 97

\section{E}

East Africa, 28, 31, 44, 45, 49

East African Colony, 44, 50, 53

East African Empire, 21, 55

East African Highlands, 40, 41, 45,50

East African trade, 22

East Coast slave-trade, 63

East Indian Empire, 27

Education dangers, 204

Education of the negro, 56, 58, 204

Education versus Evangelisation, 204

Egypt, 23
Eldoma Ravine, 85

Emin Pasha, 189

England's obligations inUganda, 169

English Cathedral, the, 181

English Church, the, 43

English hospital, 27

Entebbe, 113, 175

Equatorial Africa, 27

Etna, 23

Euphorbia, 34

Evil customs, 337-341

Evil spirits, 350

Excommunication, 215

Executive Committee, C.M.S., 217

\section{F}

Faith in the Gospel, 213

Famine, 108, 239

Father Kirk, 306

Father Spere, 306

Fibre cultivation, 33, 118

Fleas, 130

Flies, 130

Fly, the tsetse, 106

France, Southern, 23

French Ecclesiastical coup, 181

French Roman Catholic Mission, 180

French shipping line, 22

Frere, Sir Bartle, 88

Frere Town, 32, 88, 90

Frogs, 130

Frontier of German East Africa, 117

Fruit, 44 
366

G

Gallas, 37

Gang people, 86

Geographical enterprise of C.M.S., 88

German enterprise, 22

German Equatorial Africa, 27

German frontier, 117

German ships, 22

Giryama country, 64, 88

Glossina palpalis, the, 106

Gondokoro, 117

Gordon, Rev. C., 144

Government house, 27

Governor of British East Africa, $43,45,46,49$

Grammar in Lumasaba, 319

Grant, the explorer, 135

Grant, W. and T., 233

Great "fault," the, 80

Great Spirit, the, 350

Ground nuts, 117

Gulf of Suez, 23

\section{H}

Hæmoglobinuric fever, 131-132

Ham Mukasa, 120, 224

Hamitic people, 140

Hannington, Bishop, 144, 188, 228, 239

Hartebeeste, 37

Headquarters of C.M.S. Uganda Mission, 182

Headquarters of railway, 40

Hemp smoking, 337

Highlands, East African, 40, 41, $45,50,87$

High School, 192, 207
Holden, Mr. W., 306, 315

Holy Communion, questions relating to, 214

Holy Land, 23

Hornets, 130

Hospital, C.M.S., 104, 134, 188

Houses, 139, 153

Housing problem, 210

Hubbard, Rev. E., 188

Hut-tax, 57, 239, 360

\section{I}

Iganga, 233

Imperial British East Africa Company, 89, 146

India, 105

Indian coolies, 38

Indian Ocean, 22, 94

Indian Penal Code, 161

Indian, the, 54, 55

Insect life, 131

Intermingling of Aryan and Negro, 55

Irrigation, 37

Ishmael's propensities, 63

Islanders of Sese, 95

Islands of Buvuma, 97

\section{J}

Jigger, the, 105, 130

Jinja, 232, 309

Johnston, Sir H. H., 54, 151, 203, 353

\section{K}

Kampala, 125

Kamuli, 242 


\section{Index}

Kapili Plains, 39

Katikiro of Uganda, 120, 158

Kavirondo, 84, 86, 95

Kavirondo, Bantu, 64, 86

Kenya, Mount, 68, 88

Kibwezi, 89

Kidong River, 68

Kikuyu, 68, 80, 88

Kilima-Njaro, 37

Kilindini harbour, 27, 28-31

Kimaru people, 255

King David, 146, 154

King Mtesa, 136

King Mwanga's rebellion, 145

King's war drum, 137

Kirk, Father, 306

Kisi, 86

Kisumu, 84, 85, 87, 92, 114, 232

Koch, Professor, 107

Kokolyo, 249, 259

Koran, the, 33

Koromojo, 255, 260

Kumi, 256

Kyagwe, 98, 118, 141, 224

Kyoga, Lake, 86, 97, 232, 242259

\section{$\mathrm{L}$}

Labour problem in Uganda, 161-

Lado Enclave, 189

Lake Albert, 97, 260

Lake Albert Edward, 97

Lake Kyoga, 86, 97, 232, 242259

Lake Rudolph, 172, 250, 260

Lake Salisbury or Bisina, 249, 259

Lake steamers, 98-101

Lake Tanganyika, 105

Lake Victoria, 60, 80, 92-110, 226

Land distribution, 169

Land settlements, 40-59

Language, Bantu, 63

Language difficulties, 317

Lice, 130

Lions, 27, 37, 120

Liverpool School of Tropical Medicine, 107

Lossogurti Escarpment, 68

Luba of Usoga, 189

Lugard, 189

Lumasaba Grammar, 319

Lumbwa, 84, 86

Lur people, 86

\section{M}

Mabira Forest Company, 118

Macdonald, Captain, 188

Macdonald, General Sir J. C. R., 189

Mackay, Alexander, 142

Makindu, 39

Making bark cloth, 137

Malaria, 128

Manimani, 260, 265

Marseilles, 22

Masaba, 24, 223, 309

Masai, 69, 71-79, 80, 84

Mau Escarpment, 83, 87

Mbale, 359

McNamara, Miss, 315

Medicine-men, 350 
Mengo, 24, 114, 119, 150, 175

Mengo High School, 192

Meridional Rift, 80

Messina, 22

Mice, 130

Mill Hill Roman Catholic Mission, 180

Mimosa scrub, 34

Miro, 256

Missions, 56, 196

Missions, influence and work of, 196-218

Mohammedan interpreters, 91

Mohammedan traders and missionaries, 91

Mohammedanism, 31, 32

Mohammedanism, superficial, 33

Mombasa, 22, 23-28, 37, 39, 40, $43,55,60$

Mombasa native town, 31

Mosquito nets, 128

Mosquito, the, 97, 128

Mountains of the Moon, 117, 197

Mount Debasian, 249, 259

Mount Elgon, 86, 182, 223, 242, 265, 294

Mount Moroto, 260

Mount Teso, 249

Mpologoma River, 242, 250

Mtesa, King of Uganda, 136

Mukasa, Ham, 120, 224

Mukono, 120

Mumia's, 223

Munyonyo, 175

Mutilation, 141

Mwanga, King of Uganda, 141, 154

\section{$\mathrm{N}$}

Naigombwa River, 250

Nairobi, 39, 40, 43, 44, 46, 49, $53,69,80,83$

Nakasero, 180

Nandi, 84, 85, 86

Nandi warriors, 85

Namirembe, 184

Naples, 22

Napoleon Gulf, 227, 232

Nassa, 182

Native and white problems, $40-$ 59

Native, the, 60-79

Negro and Aryan intermingling, 55

Negro organisation and education, 56-59

Newspapers in Uganda, 179

Nile, the, 224, 226

Nilotic peoples, 86, 225, 260

Nominal Christianity, 90

Nsambya, 180

Numbers, danger of, 198

Nyenga, 226

\section{0}

Oasis, an, 135

Obligations of England, 169

Offerings to evil spirits, 350

Old Mombasa, 27

Organisation of Negro, 56

Ostrich, 37

P

Pagan Africans, 67

Palace of Bishop Tucker, 195 


\section{Index}

Paradise of snakes, \&c., 27

Parasites, 53

Parliament House, 157

Pax Britannica, 107, 152

Pemba, 31

Penal Code, Indian, 161

Persecution, 143

Pilgrim, Miss, 312

Pilkington, 188

Poll-tax, 57

Polygamy, 251

Porterage, 150

Port Florence, 85, 223

Port of Uganda, 113

Port Said, 23

Portuguese fort, 24

Portuguese, the, 63

Postmaster-General, 27

Preaching in Uganda, 184

Price, Rev. W. S., 88

Prime Minister of Uganda, 120, 158

Primitive simplicity, 21

Primitive tribes, 64

Printing in Uganda, 178

Progress in Uganda, 153

Prostrating heat, 23

Punitive expeditions, 361

\section{$\mathbf{R}$}

Rabai, 88, 90

Railway headquarters, 40

Railway, Uganda, 28, 32, 37, 40, $64,87,98,150,156$

Rats, 130

Ravine, the Eldoma, 85

Rebellion of King Mwanga, 145
Rebellion of Soudanese soldiers, 189

Regents in Uganda, 157

Relapsing fever, 129

Rendle, Dr., 125

Rest-houses, 129

Rhinoceri, 37, 38

Rice cultivation, 33

Right Hon. Winston Churchill, 171

Ripon Falls, 101, 109, 226

Ripon Falls Barrage, 109

River Mpologoma, 242

River Naigombwa, 250

River Nile, 224, 226

Road-making in Uganda, 166

Roads, 114, 115, 166

Roman Catholicism, 181

Roman Catholicism and renegade Anglicans, 215

Roman Catholic chapel, 43

Roman Catholic Missions, 180

Roman Catholic nonconformity, 181

Rubber cultivation, 33, 118

Rudolph, Lake, 172, 250

Ruwenzori Mountains, 260

\section{$\mathrm{S}$}

Sacrifices, 357

St. Joseph's Roman Catholic Mission, 180

Salisbury, Lake, 249, 259

Samwili Kangawo, 224

School, Mengo High, 192

Scotch Mission, 89

Scott, killed by rebels, 189

Segregation camps, 108 


\section{Index}

Self-support, 212

Selim Bey, 189

Semei Kakungulu, 239, 358

Serere, 250

Sese Islands and people, 95-98

Settlers, 45, 119

Seychelle Islands, 145

Seyidie, 33

Sheep, 44

Skeens, 231

Slave trade, 63

Sleeping sickness, 98-109

Sleeping sickness fly, 106-109

Smoking of Indian hemp, 337

Snakes, 130

Somali country, 64

Sotik, 86

Soudanese rebellion, 189

Specific Disease, 176, 202

Speke the explorer, 135

Spere, Father, 306

Spicy breezes, 23

Spiders, 130

Spirillum fever, 129, 226

Stanley, Sir H. M., 98, 136, 189

Status of Slavery, 31

Steamships on Lake Victoria, 98, 101

Strategic value of Uganda, 171

Stromboli, 23

Suez Canal, 23

Sultan of Zanzibar, 31

Swahili porter, 24

\section{T}

Taita, 88

Tanaland, 33

Tana River 64
Tanganyika, Lake, 105

Taru Desert, 34

Taveta, 88

Tax Britannica, 152

Taxation and development, 88

Technical instruction, 167

Tegetha, 260

Tepeth, 260

Teso, 241

Teso Mountain, 249

Thatching, 139

Thieves, 235

Things as they are, 21

Thruston, Major, 189

Tick fever, 129

Toposa, 261

Toro, 197, 217

Transition, 34

Translation work, 327

Tropical Medicine School, 107

Trypanosoma, 105-109

Tsavo River, 64

Tucker, Bishop, 195, 228

Tullock, Lieutenant, 105

Turkana, 255-262

\section{U}

Uganda, 22-34, 110-227

Uganda Chamber of Commerce, 161

Uganda Company, 176

Uganda houses, 139

Uganda Mission of the C.M.S., 182

Uganda newspapers, 179

Uganda Railway, 28, 32, 37, 64, $87,98,150,166$

Uganda Railway terminus, 85 


\section{Index}

Uganda Rebellion, 189

Ugaya, 86

Ukamba, 38, 88

Ukidi, 241

Unyoro, 217, 232

Usoga, 93, 97, 101, 119, 217, 241

V

Vaughan, Cardinal, 180

Vegetables, 44

Venereal disease in Uganda, 202

Vesuvius, 23

Victoria Lake, 60, 80, 92-110, 225

Visitors, not settlers, 55

Voi, 37, 38

\section{W}

Wadelai, 182

Wagiryama, 64

Wakamba, 64, 67, 68

Wakikuyu, 68, 69, 71
Walker, Archdeacon, 144

Wandorobo, 84

Wanyika, the, 34, 64

Wapokomo people, 64

War drum, 137

Wasps, 130

Wataita people, 37

West Africa, 130

White fathers, 180

Wildebeeste, $\mathbf{3 7}$

Williams, Captain, 98

Wilson, George, Esq., C.B., 165

Wilson, killed by rebels, 189

Wilson, Rev. A., 231

Witchcraft, 345

Work of Church and State, 209

Wrong ideas of permanence, 211

Wrong system in Uganda, 166

Z

Zanzibar, 31, 32

Zanzibar, Sultan of, 31

Zebra, 37 


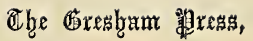

UNWIN BROTHERS, LIMITED,

WOKING AND LONDON. 



SMITHSONIAN LUBAAFIES 